University of Louisville

ThinkIR: The University of Louisville's Institutional Repository

Electronic Theses and Dissertations

$5-2017$

\title{
The cultural creation of Fulvia Flacca Bambula.
}

Erin Leigh Wotring

University of Louisville

Follow this and additional works at: https://ir.library.louisville.edu/etd

Part of the European History Commons, History of Gender Commons, Intellectual History Commons, Political History Commons, Social History Commons, and the Women's History Commons

\section{Recommended Citation}

Wotring, Erin Leigh, "The cultural creation of Fulvia Flacca Bambula." (2017). Electronic Theses and Dissertations. Paper 2691.

https://doi.org/10.18297/etd/2691

This Master's Thesis is brought to you for free and open access by ThinkIR: The University of Louisville's Institutional Repository. It has been accepted for inclusion in Electronic Theses and Dissertations by an authorized administrator of ThinkIR: The University of Louisville's Institutional Repository. This title appears here courtesy of the author, who has retained all other copyrights. For more information, please contact thinkir@louisville.edu. 
THE CULTURAL CREATION OF FULVIA FLACCA BAMBULA

\author{
By \\ Erin Leigh Wotring

\begin{abstract}
A Thesis
Submitted to the Faculty of the

College of Arts and Sciences of the University of Louisville

In Partial Fulfillment of the Requirements

For the Degree of
\end{abstract}

Master of Arts in History

Department of History

University of Louisville

Louisville, KY

May, 2017 
Copyright 2017 by Erin Leigh Wotring

All rights reserved 

THE CULTURAL CREATION OF FULVIA FLACCA BAMBULA

By

Erin Leigh Wotring

A Thesis Approved on

April 14, 2017

by the following Thesis Committee:

\begin{tabular}{c}
\hline Dr. Jennifer Westerfeld, Director \\
\hline Dr. Blake Beattie \\
\hline
\end{tabular}

Dr. Carmen Hardin 


\section{ACKNOWLEDGEMENTS}

I would like to thank Dr. Jennifer Westerfeld for sticking with me all this time, being hilarious, and always encouraging me. I would also like to thank Lee Keeling and Robin Carroll for loving me and forcing me to get my shit together. I thank Dr. Ann Allen and Dr. Yuxin Ma for shaping me as a scholar during my early years and driving me deeper into women's history. I thank Dr. Carmen Hardin for the gift of Latin and for being an amazing, positive force in the world. I would like to thank my man Bob and my brother, Eric, for indulging me and listening to me talk about Mark Antony for six years. I would like to thank my children, Milkshake and Capri, and my nephew, Ivan, for distracting me when I needed it the most. I would like to thank my mom, Tina, for always being proud of me. Lastly, I would like to thank Tom Hardy for his face. 


\section{DEDICATION}

This thesis is dedicated to my family,

To the women lost in history, And to Daisy and Bo Duke. 


\section{ABSTRACT \\ THE CULTURAL CREATION OF FULVIA FLACCA BAMBULA \\ Erin Leigh Wotring}

April 14, 2017

This study presents a scholarly and popular historiography of Fulvia Flacca Bambula with criticism of the presentation and interpretation of Fulvia as a historical character in context. Source bias caused by Augustan propaganda is widely recognized within scholarly and popular treatment of Fulvia but little attention is given to the influence of rhetoric and moral philosophy on the invective and anecdotal narratives used as source evidence in discussion of Fulvia as a Roman matron. Through assessment of traditional Roman rhetorical and literary conventions employed during the late Republican and early Imperial periods with attention to the influence of elegiac constructs in particular, the motives and personal qualities of Fulvia as described by Roman and Greek authors are shown to represent fictional tropes rather than historical realities. 


\section{TABLE OF CONTENTS}

\section{PAGE}

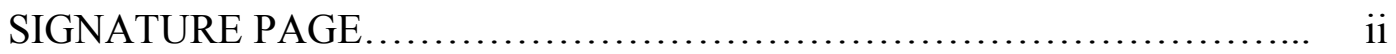

ACKNOWLEDGEMENTS ......................................... iii

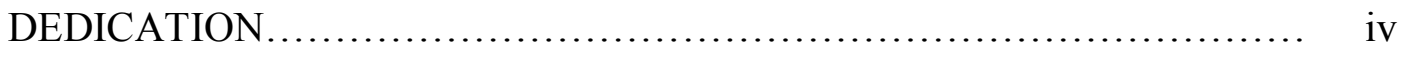

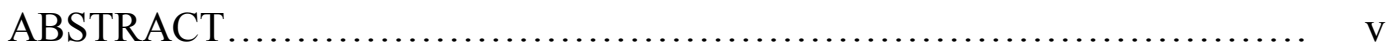

LIST OF FEATURED PERSONALITIES .............................. vii

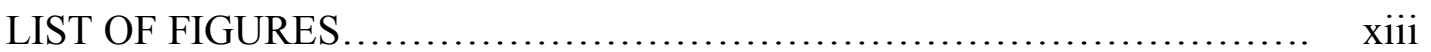

INTRODUCTION: Fulvia: Building a Historical Character................. 1

CHAPTER ONE: The Creation of Fulvia Flacca Bambula................. 8

CHAPTER TWO: Fulvia The Wife of Antony......................... 21

CHAPTER THREE: Finding Fulvia................................. 57

CHAPTER FOUR: How to Destroy a Roman Hero....................... 99

CHAPTER FIVE: “Thank Fulvia” or, Cleopatra's Rival................... 145

CONCLUSIONS: Fulvia: a Life in the Postmodern World.................. 184

REFERENCES ....................................................... 187

APPENDICES: Coins and Bullets ................................. 199

LIST OF PRIMARY SOURCE ABBREVIATIONS...................... 205

CURRICULUM VITAE........................................... 207 


\section{FEATURED PERSONALITIES ${ }^{1}$}

Agippa, Marcus

Agrippina Maior

Agrippina Minor

Antonia

Antony

Antyllus

Appian

Asconius

Asinius Pollio
M. Vipsanius Agrippa (cos. 37).

Daughter of Agrippa and Julia, daughter of Augustus

Daughter of Agrippina and Germanicus.

Antony's first cousin, second wife; daughter of Lucius Antonius Hybrida

Marcus Antonius (cos. 44, triumvir 43-32).

Marcus Antonius Antyllus, d. 30 in Alexandria; eldest son of Fulvia and Antony

Born in Alexandria at the end of the 1st cent. CE; Greek author of a history of Rome arranged ethnographically by conquest which included his Bella Civilia.

Q. Asconius Pedianus (CE 3 to 88); Latin author of a commentary on Cicero's speeches, of which his work on the Pro Milone survives.

C. Asinius Pollio (b. 79, cos. 40); Latin author of a lost history covering the years 60 to 42 which was used by both Plutarch and Appian. Antonian partisan, father of Asinius Gallus.

Atia

C. Julius Caesar's niece, mother of Octavian and Octavia.

\footnotetext{
${ }^{1}$ Political positions according to TRS Broughton, The Magistrates of the Roman Republic, Vol. 3: Supplement, (Atlanta: Scholars Press, 1986) and biographical information from RE A. Pauly, G. Wissowa and W. Kroll, Real-Encylopaedie der klassichen Alterumswissenschaft, (Stuttgart: Druckenmueller, 1893); William Smith, ed., Dictionary of Greek and Roman Biography and Mythology, (London: John Murray, 1849).
} 
Atticus

Brogitarus

Brutus

Caelius

Caesetius Rufus

Cassius

Catiline

Cicero

Cleopatra

Clodia

Clodia Pulchra

Clodius

Sextus Cloelius

Cornelia

Crassus

Curio

Cytheris

D. Brutus

Deiotarus

Dio
T. Pomponius Atticus; correspondent of Cicero; ally of Fulvia, known for neutrality

Deiotarus' son-in-law and ally of Clodius.

M. Iunius Brutus (pr. 44).

M. Caelius Rufus (trib. 52); subject of Pro Caelio and instrumental in Cicero's enmity against Clodius

(senator, 43); barely anything is known about him; only mentioned by Appian in relation to proscriptions

C. Cassius Longinus (pr. 44).

L. Sergius Catilina.

M. Tullius Cicero (cos. 63); Latin orator, philosopher, and rhetorician; also a prolific author: several manuscripts, and dozens of his speeches, invectives, and hundreds of his personal letters were also published.

Cleopatra VII, Pharaoh of Egypt.

Clodia Metelli, sister of Clodius.

Daughter of Fulvia and Clodius

P. Clodius Pulcher (trib. 58), Fulvia's first husband.

Clodius' ally

Mother of Tiberius and Gaius Gracchus.

M Licinius Crassus Dives (cos. 70).

C. Scribonius Curio (trib. 50).

Volumnia Cytheris, actress and Antony's mistress.

D. Iunius Albinus Brutus (cos. desig. 42).

Tetrarch of Galatia.

Cassius Dio (b. ca. CE 164; d. after 229); Greek author of a history of Rome from its foundation to CE 229. 
Domitian

Florus

Fulvia

Glaphyra

Hadrian

Hortensia

Iullus

Juba

Julia

Julia

Lentulus

Lepidus

Livia

Livy

Lucius

Manius

Marius
T. Flavius Domitianus (emperor CE 81 to 96).

L. Annaeus Florus, Latin author of the Epitome de Gestis Romanorum, wrote under the reign of Trajan or of Hadrian

Daughter of M. Fulvius Bambalio and Sempronia.

Cappadocian courtesan, Antony's mistress

P. Aelius Hadrianus (emperor CE 117 to 138).

Daughter of the orator Hortensius.

Iullus Antonius (cos. 7), author and younger son of Fulvia and Antony

King of Numidia: joined Pompey in 49, killed in 46.

Mother of Antony,

Daughter of Octavian by Scribonia, exiled for relationship with Iullus Antony.

P. Cornelius Lentulus Sura (cos. 71), Antony's stepfather, executed by Cicero in 63 .

M. Aemilius Lepidus (cos. 46).

Livia Drusilla, third wife of Octavian.

T. Livius (59 BCE to CE 17); Latin author of the Ab urbe condita libri, an account of Roman history from its mythical origins to $9 \mathrm{BCE}$; the relevant books for Fulvia's life do not survive, although there are short summaries (Periochae) of each book written by an anonymous author ca. 4 th cent. $\mathrm{CE}$

Lucius Antonius (cos. 43), younger brother of Antony; involved in Perusian War with Fulvia Antony's procurator in 41; very little is known about him. C. Marius (cos. 107). 
Martial

Milo

Nepos

Octavia

Octavian

Plutarch

Pompey

Quintilian

Sextus Pompey

Plancus

Sempronia (1)

Sempronia

Seneca

Suetonius
M. Valerius Martialis (b. ca. CE 38 to 41; d. ca. 101 to 104); Latin author of epigrams.

T. Annius Milo (pr. 55); convicted in 52 for murder of $P$. Clodius Pulcher after being defended by Cicero,

Cornelius Nepos (b. ca. 110; d. 24); Latin biographer, including that of Atticus.

Sister of Octavian, Antony's fourth wife; adopted Iullus Antonius after Fulvia's death.

C. Octavius, called C. Caesar after his posthumous adoption by G. Julius Caesar. Received title of Augustus in 27. Generally referred to as Octavian before 27 and as Augustus after.

L. Mestrius Plutarchus (b. ca. CE 50; d. after 120); Greek author and moralist. Author of philosophical works and comparative biographies, including biographies of Antony and Cicero.

Cn. Pompeius Magnus (cos. 70).

M. Fabius Quintilianus, Rhetorician (b. CE 40-118), held endowed post under Vespasian, dedicated client of Hadrian.

Sex. Pompeius Magnus Pius (cos. desig. 35); one-time pirate, sometime ally of Antony. Safely brought Julia to Greece after Perusia.

L. Munatius Plancus (cos. 42).

Educated Roman matron implicated by Sallust in relationship with Cataline, aunt of Fulvia.

Daughter of C. Sempronius Tuditanus, mother of Fulvia, sister of Sempronia (1).

Rhetorician

C. Suetonius Tranquillus (b. ca. CE 70); Latin author Lives of the Twelve Caesars. 
Tiberius

Tiberius Claudius Nero

Turia

Valerius Maximus

Velleius Paterculus
Tiberius Julius Caesar Augustus (emperor CE 14 to 37).

First husband of Livia and Antonian partisan.

Praised by her husband in a long funerary inscription (CIL VI.1527), and seen as an ideal Roman matron.

Author under the reign of the emperor Tiberius; Latin author of a book of exempla, the Factorum ac dictorum memorabilium libri IX

Author under the reign of the emperor Tiberius; wrote a succinct history of Rome. 


\section{INTRODUCTION}

\section{FULVIA: BUILDING A HISTORICAL CHARACTER}

It is strange that no writer of fiction has ever thought of making Fulvia his heroine. Ambitious, jealous, cruel, avaricious, and vengeful, she made herself mistress of Roma and ruled Italy with a capricious tyranny, which surpassed that of the triumvirs. ${ }^{1}$

Frank W. Abbott's 1909 quote about Fulvia Flacca Bambula, Roman matron of the late Republic, and her personal character represent a version of Fulvia clearly painted by her contemporary sources. Abbott has read Cicero and Plutarch and used their descriptions of Fulvia to create his 1909 version of Fulvia. In doing so, Abbott has supposed that the woman described by Cicero, Plutarch, Dio, and Appian was real. Abbott accepts that the ancient authors created a realistic portrait of Fulvia that does not require interpretation or critical analysis. Abbott is not alone-from Cicero onward the majority of authors have accepted textual representations of Fulvia as real or representative of a reality that did exist as described by ancient authors. The Greek Platonist philosopher and moralist Plutarch wrote, "Cleopatra was indebted to Fulvia for teaching Antony to endure a woman's sway, since she took him over quite tamed, and schooled at the outset to obey women. ${ }^{2 "}$ Plutarch composed his Parallel Lives during the Flavian dynasty, a rebirth for Rome after the chaos of Nero and the so-called Year of

\footnotetext{
${ }^{1}$ Frank W. Abbott, Society and Politics in Ancient Rome, (NY: Charles Scribner's Sons, 1909), 72.

2 Plut., Vit. Ant., 10.5.
} 
Four Emperors. A collection of essays autopsying the moral failings and character flaws of Rome's fallen heroes naturally included Marcus Antonius, the last demagogue of the Republic, whom the Romans of the day understood to have been bewitched by the Pharaoh Cleopatra VII. It is between these two monolithic personalities, Antony and Cleopatra, forever connected thanks in part to William Shakespeare, that Fulvia Flacca Bambula is mentioned in passing. Her is was tossed out whenever a rhetorician desired to explain the downfall of the once-promising Antony. She is called upon as the antithesis of a Roman woman; an androgyne incapable of contentment with her familial responsibilities as a matron. Mention of Fulvia is a footnote to the story of Antony, a rumor perpetuated by those seeking to prescribe behavior to women, a startling piece of evidence of the turbulent fall of the Republic, or as a new type of exempla often cited feminist scholars - a fantastic example of the fragility and futility of gender roles. ${ }^{3}$

The sources are unclear, at times ambiguous, silent, and slanderous. Whether Fulvia was a woman driven by her personal ambition who utilized the existing systems when she was able, orchestrating her marriages and wielding her husbands as a matter of achieving status and power de facto, or the victim of a smear political campaign lasting centuries continues to be a matter of debate. This thesis will show that the "written" Fulvia cannot be taken at face value. The nature of the literary, cultural, political, social, and historical contexts which intersect to create Fulvia have not created a portrait, they have created a caricature. Examination of the elements of propaganda as well as rhetorical and literary conventions of the late Republic and Imperial periods will

${ }^{3}$ Gillian Clark, "Roman Women" in Women in Antiquity, eds. Ian McAuslan and Peter Walcot (Oxford University Press, 1996) 51; Eleanor Goltz Huzar Mark Antony: A Biography. (Minneapolis: University of Minnesota Press, 1978): 26. 
demonstrate that while biographic elements may be drawn from the narrative, the motivations, personal character, and actions of Fulvia represent a historical character called Fulvia created to support political and moral narratives of the Augustan regime using Augustan literary conventions. The 'real' Fulvia, her thoughts, her desires, her personality are lost to us, buried under layers of literary constraints and moral judgments. The written Fulvia is many things: evidence designed to undermine her husband Mark Antony, Fulvia is a foil for Octavia the late Republic's ideal matron, and an explanation for Antony's connection to Cleopatra VII. Fulvia is used to represent the moral degeneracy used by early Augustan writers to explain the fall of the Republic and the need for moral reform in the early Empire. Outside of her specific historical narrative Fulvia is written as a woman upsetting traditional gender norms; this interpretation is either positive or negative depending on the historical and contemporary world view of the author.

The concept of the "written woman" as a methodological framework for textual analysis is drawn from the works of Maria Wyke, Amy Richlin, and Suzanne Dixon. Wyke defines the written woman as reflective of social, moral, and literary discourses. Richlin wrote that accounts of women's actions shift from genre to genre each "telling the portion of truth which its audience had come to hear." Written women are subject to the idiom of literary genre. Suzanne Dixon's Reading Roman Women demonstrates the importance of literary genre in Roman constructions of gender and of women as written figures. My study examines the mechanisms of generic conventions operative in literary and non-literary sources. Following the interpretive framework outlined by Richlin and Dixon in assessing elements of diverse genres including invective epigrammatic poems, 
biographies, and historical narratives, I demonstrate the impact of genre in the construction of Fulvia as a historical character. This analysis proves that the written Fulvia is a construction designed by genre and representative of authorial intent.

To date there is one complete biography of Fulvia, Allison Jean Weir's Master's Thesis: "A Study of Fulvia." ${ }^{4}$ Weir's thesis is the first biography to incorporate in one narrative Fulvia's life, her death, and then continue to interpret the consequences of her life in the sources. Weir's study is builds upon Charles Babcock's interpretation of Fulvia as political organizer and Delia's reassessment of Fulvia as a wife and mother. She also incorporates Hallett's material and textual interpretations of evidence connected to the life of Fulvia. ${ }^{5}$ Where Weir's thesis is biographic this thesis will move from biography to literary interpretation and follow the cultural usage of Fulvia as a historical character through historiographic and popular sources. It asks why has Fulvia been written about in the way she has been written about and demonstrates how have authors used Fulvia over time to color narratives of the Republic and prominent personalities like Clodius and Antony.

The idea of exploring the cultural history of Fulvia came to me while reading The Creation of Anne Boleyn by feminist historian and critic Susan Bordo. ${ }^{6}$ Bordo hypothesizes that narratives about prominent historical figures (those who have a popular mythology) are influenced by the popular mythology surrounding the character.

\footnotetext{
${ }^{4}$ Allison Jean, “A Study of Fulvia.” Master's Thesis, Queen’s University, Kingston, Ontario, Canada December, 2007.

${ }^{5}$ Charles Babcock, "The Early Career of Fulvia." The Journal of American Philology 86 (Jan., 1965): 1-32; Diana Delia, "Fulvia Reconsidered" in Women's History as Ancient History, edited by Sarah B. Pomeroy, (Chapel Hill: University of North Carolina Press, 1991): 197-217; Judith Hallett, "Perusinae Glandes and the Changing Image of Augustus." AJAH 2 (1977): 151-71.

${ }^{6}$ Susan Bordo, The Creation of Anne Boleyn: A New Look at England's Most Notorious Queen. (Boston: Houghton-Mifflin Harcourt, 2013).
} 
Historians are not immune: they use literary elements to color their narratives, and sometimes use narrative exposition instead of evidence to demonstrate a point. Bordo assert that the issue with literary coloring is that there is often little indication that embellishment or speculation is taking place and so elements of a historical character's personality or motivation are used as "established fact." The problems with interpreting Anne Boleyn because of her treatment in contemporary sources and how sources have been interpreted by scholars to create a popular image that has changed over time evoked such parallels with the life and historical treatment of Fulvia that I sought to examine Fulvia's life using the idea of the creation of a cultural image as a research framework.

The biographies of both Fulvia and Anne are dominated by rhetoric, moral judgment, and religious elements. Anne is described as controlling, bewitching, and dominating Henry, mirroring Fulvia's control of Antony. Anne even has her own Cicero. Much of the hostility and negative perceptions of Fulvia and her actions come from Cicero, her contemporary, and her enemy. ${ }^{7}$ Much of the legacy of Anne Boleyn comes from Eustace Chapuys, ambassador of Charles V. Chapuys hated Anne and his anecdotes for most of the basis for her as a historical character. How does this effect Fulvia? Like with Anne and Chapuys, historians have used scandalous, hostile sources (i.e. Cicero and Cassius Dio) to form a character for Fulvia "fortified by a foundation of titillating, crowd-pleasing, mythology." The mythology has in-turn been legitimized by historians and scholars "who have accepted ... reports as biased but accurate, and hardened them, over time, into history." ${ }^{8}$ The blurring of fact and fiction in the personal character and actions of historical figures because of a cultural presence or mythology causes

\footnotetext{
${ }^{7}$ Bordo, The Creation of Anne Boleyn, 6-8.

${ }^{8}$ Ibid., 15.
} 
interpretation of the figure to be influence by preconceived notions drawn from the mythology. Bordo demonstrates that scholarly description of Anne Boleyn is often embellished with pop culture elements. In the case of Fulvia, she is often written with her mythology paraphrased and intertwined with source material, which it in itself, the origin of the mythology. Negative characteristics ascribed to Fulvia in invective against Antony have been used uncritically and expanded and built upon over time. A key goal of this thesis is to demonstrate flaws in the original sources of Fulvia's negative image and to show how those original sources in coordination with secondary interpretations of Fulvia have created her as a character. Because Fulvia's character was created to act with Antony's character and his downfall, the research framework is largely limited to Fulvia in relationship to Antony. Fulvia is also present in the lives of Cicero and Octavian, and though I do explore how those relationships have shaped the image of Fulvia, that branch of research has not been exhausted and is in need of further consideration.

Chapter one "The Creation of Fulvia Flacca Bambula" gives a biographic sketch of Fulvia to establish key events during her lifetime and to provide background on Fulvia's enmity with Cicero. Chapter two "Fulvia the Wife of Antony" is more expansive. This chapter demonstrates the importance of Fulvia to Antony's legacy while outlining how biographers of Antony have shaped Fulvia as a character. This begins an in-depth analysis of Fulvia in Plutarch's Life of Antony that weaves in to chapters three and four, with a focus on Plutarch's use of Cicero as a core source in Antony's biography. This chapter goes on to examine modern biographies of Antony and trends in the portrayal of Fulvia in said biographies. 
Chapter three "Finding Fulvia" gives a historiography of Fulvia with exposition on scholarly trends interpretation of her image. A core aspect of scholarship is the changing methodologies and research motives of the women's history movement, specifically women's history within Classical studies. Chapter three expands on literary criticism and feminist theory as it relates to the changing image of Fulvia. This chapter aims to rectify Fulvia as a historical character, a written woman, and the problems that designation brings. If Fulvia is a character, how can she be interpreted? Fulvia can be found as the product of her historical context. This chapter shows that the use of literary theory and critical assessment of anecdotal evidence can help give us glimpses of the 'real' woman behind the layers of textual construction.

Chapter four "How to Destroy a Roman Hero (or the Destruction of Hercules)" explores the role of Augustan propaganda and Roman rhetoric on Antony and on Fulvia in turn. This chapter explores the conventions of genre and mechanisms of rhetoric that may be responsible for the written personality and deeds of Fulvia. Chapter five "“"Thank Fulvia” or Cleopatra's Rival” examines Fulvia's image in popular culture. Because Fulvia is very rarely the main subject of popular writing, she is examined in relation to Antony and Cleopatra. This chapter also follows Fulvia's image in narratives of the fall of the Republic and synthesized texts on ancient women. These chapters will work in coordination with one another to offer interpretation of Fulvia as a historical character and will be demonstrative of the impact of rhetoric, propaganda, genre, and literary convention on that character. 


\section{CHAPTER 1}

\section{THE CREATION OF FULVIA FLACCA BAMBULA}

Fulvia Flacca Bambula is commonly known as 'Fulvia, third wife of Mark Antony.' However, she is also understood to have potentially been an unwavering friend of Julius Caesar, enemy of Cicero and Octavian, and inheritor of the political legacies of two legendary families, the Fulvii and the Gracchi. ${ }^{1}$ In $41 \mathrm{BCE}$, she may have wielded supreme power within the Roman senate as an unofficial triumvir. ${ }^{2}$ Each of these facets of Fulvia's life or "career" is a matter of interpretation due to the nature of the source material. This chapter consists of a narrative profile of the life of Fulvia and a historiography of her contemporary sources, M. Tullius Cicero and Cornelius Nepos. As scholarly interpretations of the sources are also unclear, I generally discuss Fulvia's contentious place in modern scholarship and theories associated with her biography based on the source evidence.

The facts are limited. They are as follows: Fulvia Flacca Bambula was born circa 86-80 BCE, at Tusculum, ${ }^{3}$ the only child of M. Fulvius Flaccus Bambalio and Sempronia, daughter of Sempronius Tuditanus. ${ }^{4}$ She was married in succession to

\footnotetext{
${ }^{1}$ Charles Babcock, "The Early Career of Fulvia." The Journal of American Philology 86 (Jan., 1965): 3, 5; Diana Delia "Fulvia Reconsidered" in Women's History as Ancient History, edited by Sarah B. Pomeroy, (Chapel Hill: University of North Carolina Press, 1991).

${ }^{2}$ Dio, 48. 4, Fulvia "managed affairs [of state] herself, so that neither the senate nor the people transacted any business contrary to her pleasure."

${ }^{3}$ Cic., Phil., 3.16.

${ }^{4}$ Asc., Milo, 35.
} 
Publius Clodius Pulcher, Gaius Scribonius Curio, and Marcus Antonius. She gave birth to at least four children: Clodia, P. Clodius Pulcher, ${ }^{5}$ G. Scribonius Curio, ${ }^{6}$ Marcus

Antonius Antyllus, and Marcus Antonius Iullus. ${ }^{7}$ She testified in the trial of Milo after his murder of Clodius. ${ }^{8}$ She campaigned for Antony when his political enemies attempted to have him named an enemy of the Roman people. She was somehow involved (in name as a patron or as a leader) with a revolt that led to the siege of Perusia. ${ }^{9}$ She was escorted to Greece and died there shortly after her arrival. Fulvia married Publius Clodius Pulcher around 62 BCE during the Praetorship of Julius Caesar and Consulate of Cicero. Their marriage was the stuff political dynastic dreams are made of — Clodius was actually a Claudian, a gens wielding patrician might since the dawn of the Republic; the Fulvii were established members of the plebian elite and Fulvia was most likely wealthy beyond measure as the heir of both the Fulvii and the Tuditani Gracchi. ${ }^{10}$

Fulvia was around twenty years old, her husband around thirty with an already distinguished career. He was and is called a demagogue and popularis. By $62 \mathrm{BCE}$ Clodius had already served as legatus, praefectus, and military tribune, served under Lucius Lucullus in the war against Mithridates, and made a name for himself in Rome prosecuting Catiline.${ }^{11}$ Catiline's acquittal and defeat in the Consular elections of $64 \mathrm{BCE}$

${ }^{5}$ Cic., Phil. 2.48, 55.

${ }^{6}$ Dio, 51.2; PIR 2 ; W. K. Lacey, "The Tribunate of Curio," Historia, X (1961): 318-29.

${ }^{7}$ Lily Ross Taylor, Party Politics in the Age of Caesar, (Berkeley, 1949): 7, 25, 34, 39.

${ }^{8}$ Cic., Mil.; Asc. Mil. 35.

${ }^{9}$ App., B. Civ., 5.2.14, 5.3.19, 5.5.41; Dio, 48.10.3, 48.14.3, 48.15.1; Vell. Pat., 2.74.3.

10 Plut., Life of Gaius Gracchus, 10. This makes her related to both the Gracchi Brothers and Scipio Aemilianius. The Fulvii and the Sempronii had been allies since the mid-140s BCE.

${ }^{11}$ Cic., Att., 1.14.5; Babcock, "Early Career," 15; David F. Epstein "Cicero's Testimony and the Bona Dea Trial," Classical Philology 81 (July, 1986). Populares relied on the people's assembly (collegia) and position as tribune to perform politically; the singular is popularis. The optimates and populares differed in their political views on the nature of the Republican government. Optimates were traditionalists who held that the best families must maintain Rome through her laws, populares felt that Rome must change her laws according to popular will and need. 
led to his infamous conspiracy. Catiline and his compatriots aspired to execute most of the plebian nobility and senators in order to create a pure patrician oligarchy. Cicero later accused Clodius of association with the conspirators in their botched coup d'état. ${ }^{12}$ Clodius responded by protecting himself and his patron Murena through an informal alliance of men of the equestrian order, the plebian nobility, and their plebian and citizen clientele- this group is generally referred to as Clodius' gang, the Clodiani. The faction supporting Clodius was built upon loyalty to his gens and support of his legislative program. Jeffrey Tatum explains, “Clodius' legislative program won enormous popularity for its author and soon gave him the opportunity to devise novel ${ }^{13}$ means for the rapid and violent mobilization of the plebs urbana." ${ }^{14}$ Mobilization of the plebs was a modified style of the demagoguery of the Gracchi, his wife's ancestors, to 'encourage' senatorial support of his political platform through public pressure and mob violence. $^{15}$

The year Fulvia wed Clodius he was prosecuted by Cicero for allegedly breaking the sacred rites of the festival of Bona Dea, the Good Goddess. Clodius allegedly snuck into the house of Julius Caesar dressed as a woman ${ }^{16}$ during the female-only rites of the Bona Dea. Clodius' alibi was refuted by Cicero in open court and Cicero refused to let the affair rest. He attempted to cite Clodius' "cross-dressing" as a mark of his degenerate

\footnotetext{
12 Plut., Cic., 29; Epstein, “Cicero's Testimony," 230. "Cicero portrays his conduct against Clodius as an extension of his struggle with Catiline, professing to see some continuity between the Catilinarians of 63 and Clodius' supporters."

${ }^{13}$ App., B. Civ., 5.7.62; Plut., Vit. Ant., 30.5

${ }^{14}$ Tatum, The Patrician Tribune: Publius Clodius Pulcher (Chapel Hill: UNC Press, 2010): 114.

${ }^{15}$ Eleanor Winsor Leach, "Gendering Clodius" The Classical World 94 (Summer, 2001): 338.

${ }^{16}$ Suet., Iul., 6.2 "In place of Cornelia he took to wife Pompeia, daughter of Quintus Pompeius and granddaughter of Lucius Sulla. But he afterward divorced her, suspecting her of adultery with Publius Clodius; and in fact the report that Clodius had gained access to her in woman's garb during a public religious ceremony was so persistent, that the senate decreed that the pollution of the sacred rites be judicially investigated." See also Cic., Att., 1.12.3; Cic., Har. Res., 20.11-21.44.
} 
nature. ${ }^{17} \mathrm{He}$ was narrowly acquitted in $61 \mathrm{BCE}$ and it is widely believed that he probably financed his freedom by bribing the jurors. ${ }^{18}$ Despite the personal allegations against him, he was nonetheless politically influential as a staunch supporter of Caesar and proponent of the anti-oligarchical plebian-oriented platform. ${ }^{19}$ Clodius was adopted into a plebeian family by $59 \mathrm{BCE}$ so that he might serve as Tribune of the Plebs in $58 \mathrm{BCE}$. His success only widened the personal and political gap between Cicero and Clodius. ${ }^{20} \mathrm{He}$ gained popular support by passing four bills, one of which reconstituted the plebian collegia, previously outlawed in $64 \mathrm{BCE}$; the second bill provided free grain to all citizens, and placed control of said gain supplies directly in the hands of the Plebian Tribune. ${ }^{21}$ Clodius immediately invoked his powers as Tribune ${ }^{22}$ to pass Leges Clodiae, legislation that guaranteed exile to anyone who executed a Roman citizen without due process of trial. Cicero, as consul, had executed members of the Catiline conspiracy without formal trial. Clodius clearly intended the law to rid him and his allies of Cicero. When Cicero's appeal to Pompey to grant indemnity through a senatus consultum ultimum was denied, he went into exile.

Despite the political turmoil and uneasy social state of the republic, Fulvia and

\footnotetext{
${ }^{17}$ Eleanor Winsor Leach, "Gendering Clodius” The Classical World 94 (Summer, 2001): 337-8.

${ }^{18}$ Cic., Har. Res., Cicero alluded to Clodius' new found poverty "he came off from the trial like a naked man from a shipwreck;" Cic., Att. 1.16.10; Plut., Vit. Cic., 29.6-7.

${ }^{19}$ As noted in Tatum, The Patrician Tribune, though it was Julius Caesar's right by law to prosecute Clodius for the violation of his home and of his wife; he charged Clodius with neither. See also Plut., Vit. Cic., 29.9.

${ }^{20}$ Clodius' adoption was crucial because tribunes were required to be plebeians. Lucius Cornelius Sulla had severely curtailed the role and rights of the tribunes of the plebeians by invalidating their power of veto and making it illegal for them to bring laws before the Conciliar Plebes without the Senatorial consent. Thanks to the machinations of Clodius, Crassus and Pompey restored the sacrosanctity of the tribunate. "Clodius' adoption was engineered and executed by Caesar and Pompey in order to silence Cicero." Tatum, The Patrician Tribune, 108.

${ }^{21}$ Cic., Piso, 9.

22 Plut., Vit. Cic., 32. Tribunes alone could enforce Provocatio, a theoretical guarantee of due process. A tribune had to assess the situation, and give the magistrate his approval before the magistrate could carry out the action.
} 
Clodius were personally and professionally successful. Fulvia had given birth to a daughter, Claudia/Clodia, and she and Clodius had confiscated Cicero's grand property on the Palatine. Clodius, in a blatant show of his beneficia and auctoritas, demolished the house and built a shrine to Libertas. ${ }^{23}$ As popularis, hero of the plebs and urban poor, Clodius was among the most powerful men in Rome and according to Cicero, Fulvia was highly visible as his wife. ${ }^{24}$ Clodius' power was threatened by Titus Milo who rallied forces in opposition to Clodius and the Caesarian faction. In January 57 BCE Clodius employed his faction, the Clodiani, in attempt to block a senatorial move to recall Cicero from exile and was violently countered by Milo's gladiators. ${ }^{25}$

Throughout 56 BCE Cicero was subsequently attacked by Clodius' gangs. In defense he aligned himself with Milo and attempted to prosecute Clodius for the violence but was unsuccessful at doing so. When he tried to prosecute Clodius again for the same crime, Clodius was immune from prosecution as curule aedile. In a stunning display of audacity, Clodius impeached Milo for public violence. In $52 \mathrm{BCE}$, Clodius ran for praetor against Titus Annius Milo. The contest ended in blood when Clodius was murdered by Milo and his gang on the Appian Way. ${ }^{26}$ It was as the widow of Clodius that Fulvia showed Rome that she was not to be taken lightly. Both Cicero and Quintus Asconius Pedianus describe Fulvia's public spectacle of overwhelming grief as she

\footnotetext{
${ }^{23}$ Vell. Pat., 2.14.1; Walter Allen, Jr. "Cicero's House and Libertas," Transactions and Proceedings of the American Philological Association 75 (1944), 1-9.

${ }^{24}$ Cic., Mil., 28. During this political turmoil Fulvia gave birth to a son also named Publius Clodius Pulcher. ${ }^{25}$ Tatum, Tribune, 194-6.

${ }^{26}$ Dio, 48.2; Asc., Mil., 30-35. "Quintus Caepio concerning this slaughter of Publius Clodius. He stated that it was a lie that Milo was defending himself, but that Clodius was accompanied by 26 slaves when he had set off to give a speech to the Town Council of Aricia. But suddenly, after 10:00 a.m., when the Senate meeting ended, Milo rushed off after him with more than 300 armed slaves, and attacked him unawares during his journey, beyond Bovillae. At that point, Publius Clodius, having suffered three wounds, was carried to Bovillae. The tavern in which he had taken refuge was attacked by Milo. Clodius was drug out semiconscious and killed on the Appian Way. His ring was pried off his finger as he lay dying."
} 
paraded his corpse through the streets of Rome to exhibit the brutality of his death. Fulvia "displayed his wounds with unrestrained grief." ${ }^{27}$ Asconius cites the brazenness of her gestures as inciting the mob that took Clodius' body into the senate house for cremation. Geoffrey S. Sumi describes the Roman aristocratic funeral as "the last public performance for an aristocrat whose career was built on such performances." ${ }^{28}$ It was Fulvia's right and responsibility to prepare her husband's body for viewing and funeral rites. It is telling that she did not. She openly displayed him unwashed and unaltered "although there was ample time to do so." ${ }^{29}$ It would seem that Fulvia understood the symbolism inherent in Clodius' mangled body—he was the evidence she required to bring his murders to justice. In fact, the crowd made attempts on Milo and his compatriots several times; Milo's house was set ablaze more than once. Sumi asserts that the mob was primarily responsible for the course of Clodius' funeral; though Fulvia or tribunes Plancus and Rufus could have directed or initiated events, the crowd was ultimately in control. ${ }^{30}$ Cicero served as defense council at Milo's trial; both Fulvia and her mother Sempronia testified, ${ }^{31}$ and "by their tears they greatly moved those who were in attendance." 32

Fulvia inherited both the gangs Clodius had controlled during his lifetime and the political status associated with being his widow. As mother of Clodius' two children, Fulvia became the guardian of his legacy and the loyalty of his allies and constituents was held by her in perpetuity. Katharine Welch claims that this power was able to be

\footnotetext{
${ }^{27}$ Asc., Mil., 28, 35.

${ }^{28}$ Geoffrey S. Sumi, "Power and Ritual: The Crowd at Clodius' Funeral," Historia: Zeitschrift fur Alte Geschichte 46 (1, 1997): 80.

${ }^{29}$ Ibid., 95.

${ }^{30}$ Sumi, "Power and Ritual," 92.

${ }^{31}$ Cic., Prov., 10.24.

32 Asc., Mil., 35, 40. Milo was eventually convicted. App., B. Civ., 2.4.
} 
transferred onto Fulvia's future allies and husbands, a fact not lost on Gaius Julius Caesar who needed her political support. ${ }^{33}$ Fulvia's widowhood ended in 52-51 BCE when she wed Gaius Scribonius Curio. Though initially an optimate from a staunchly patrician family, Curio became a popularis soon after marrying Fulvia, continuing Clodius' popularist policies. Curio also inherited Clodius' position with Caesar and the Clodiani. Within a year he was Plebian aedile. The family of Curio was as prestigious as the Claudii and it is likely that he did not need Fulvia financially as Clodius had. ${ }^{34}$ With the outbreak of the Civil War Curio became praefectus in Italy and propraetor in Africa. His African campaign against King Juba of I of Numidia led to his death in August of 49 BCE. ${ }^{35}$ Fulvia was either pregnant at the time or had recently given birth to their homonymous son when she was widowed a second time. ${ }^{36}$

Fulvia wed Antony in between 49-47 BCE after Antony divorced his wife Antonia. ${ }^{37}$ They were both in their mid-to-late thirties, and while Fulvia had been raising her three children, Antony had been raising through the curus honorum. According to Plutarch, Caesar was relieved at their marriage - all the more as it resulted in Antony ending his scandalous liaison with the Greek actress Volumina Cytheris. ${ }^{38}$ Plutarch also notes that Antony had known both Curio and Clodius since they were very young men, implying that Fulvia and Antony were well acquainted with one another. Their marriage

\footnotetext{
${ }^{33}$ Kathryn E. Welch, "Antony, Fulvia, and the Ghost of Clodius in 47 BC," Greece \& Rome Second Series, 42. 2 (Oct. 95): 182.

${ }^{34}$ Babcock, "The Early Career," 9; Clodius' father died when he was young, leaving him little inheritance. What was left had to be divided between three brothers and two sisters, hardly a foundation for a Roman man entering the costly world of politics.

${ }^{35}$ App., B. Civ., 2.7.44- 45.

${ }^{36}$ Babcock, "The Early Career," 18; Cic., Fam., 2.1-6.

${ }^{37}$ Babcock, "The Early Career," 18; This date is uncertain. They had two children when Cicero began the Philippics in 44. It is thought they may have already been sexually involved before Antony's divorce. See Babcock, "The Early Career," 13; Huzar, Antony, 99; Virlouvet, "Fulvia," 71; Welch, "Ghost,"192.

${ }^{38}$ Plut., Vit. Ant., 9.1-3.
} 
was also one of common cause - as a Caesarian supporter Fulvia could do no better than Caesar's Master of Horse (magister equitum). ${ }^{39}$ After Antony was finished assisting Caesar in Cisalpine Gaul, he served as administrator of Rome while Caesar was hunting the last of Pompey's supporters in North Africa. ${ }^{40}$ By 44 BCE he was consul despite having never served as praetor. ${ }^{41}$ Their marriage produced two sons, Antyllus and Iullus. $^{42}$

Like Curio, Antony received popular allegiance from the former followers of Clodius as well as those of Curio. Despite his alleged preference for illicit activities, drinking and carousing in particular, ${ }^{43}$ which were perceived to be unbecoming a man of his birth and rank, Antony found personal popularity among the Roman people apart from those favoring the old order of optimates, like Cicero and Cato. Antony was consul with Caesar as co-consul. In the name of the people, Antony publicly offered Caesar a crown at the Lupercalia. After the assassination of Caesar in $44 \mathrm{BCE}$, Antony recreated Fulvia's funerary theatrics after the death of Caesar by displaying the slain dictator's wounds and bloody toga for political gain. She may have also been the inspiration for Antony removing the entirety of Caesar's papers to their home. ${ }^{44}$ Antony, as surviving consul, convened the senate and with Lepidus, magister equitum, established order and

\footnotetext{
${ }^{39}$ Dio, 47, 29-33; Plut., Vit. Ant., 2.2-.3, 5.1.

${ }^{40}$ Plut., Vit. Ant., 5.4.

${ }^{41}$ Babcock, "The Early Career," 20 . This is not the usually course of advancement.

${ }^{42}$ Plut., Vit. Ant., 10.5. "Antony tried, by sportive ways and youthful sallies, to make even Fulvia more lighthearted." Arthur Weigall in Cleopatra Queen of Egypt (NY: Garden City Publishing, Inc., 1924) 223: writes of their personalities, "To keep this strong-minded woman in good humor the guileless Antony was wont to play upon her all manner of boyish pranks; and it would seem that he took delight in bounding at her from the dark corners of the house and the like."

${ }^{43} \mathrm{He}$ was also known for "the pitching of tents when he travelled, at the laying out of costly repasts near groves and rivers, at chariots drawn by lions, and at the use of honest men and women's houses as quarters for harlots and psaltery-players." Plut., Vit. Ant., 9.5

${ }^{44}$ Plut., Vit. Ant., 14.3, 15.2. Babcock theorizes that Fulvia orchestrated Antony's actions following the death of Caesar.
} 
sought to carry out the will of Caesar. The senate confirmed the acts of Caesar and agreed to the terms of his will, but, under the direction of Cicero, offered amnesties to his murderers.

"He [Deiotarus], of course, is worthy of any kingdom, but not through Fulvia." 45 The above was written by Cicero from his lavish villa in Puteoli Cicero to T. Pomponius Atticus concerning King Deiotarus and his Philippics. ${ }^{46}$ Deiotarus had been accused of attempted to assassinate Caesar when he was his guest in Galatia. The case had been presided over by Caesar with Cicero providing Deiotarus' defense. He came to no verdict before the assassination. After Caesar's death, Antony decreed that in accordance with Caesar's will, Deiotarus was to resume possession of his former territory. Cicero proclaimed that this was not truly Caesar's will but rather a deal struck between Antony and Deiotarus in exchange for a vast sum of money and Fulvia's sexual favors. ${ }^{47}$

Hostility also developed between Antony, as Caesar's political heir, and Octavian as Caesar's legal heir. Antony had his Macedonian gubernatorial appointment changed, by force of arms, into a five-year tenure in Cisalpine Gaul. In early 43 BCE Antony left after appropriating Caesar's four legions in order to bring justice to Decimus Brutus in Mutina. It was during this period that Cicero began his tirades against Antony with the intention of stirring the senate and swaying popular support towards declaring Antony an enemy of Rome. Fulvia canvassed and begged senators not to fulfill Cicero's wishes. ${ }^{48}$ She was unsuccessful. The Roman Senate denounced Antony and granted Octavian the command of forces to meet Antony's. Antony's forces were defeated at the Mutina,

\footnotetext{
${ }^{45}$ Cic., Att., 14.12.1, Deiotari nostri causa non similis? dignus ille quidem omni regno sed non per Fulviam ${ }^{46}$ Cic., Phil., 2.95.

${ }^{47}$ Ibid.

${ }^{48}$ App., B. Civ., 3.8.51.
} 
forcing Antony to retreat to Transalpine Gaul ${ }^{49} \mathrm{~T}$. Pomponius Atticus, esquire, was a friend to both Cicero and Fulvia; Cornelius Nepos, in his biography of Atticus, described the personal and legal effects of Antony's political career on Fulvia as she was forced to seek asylum with the neutral and much loved Atticus. ${ }^{50}$ This description relates not only the danger that Fulvia and the children faced, it demonstrates the degree to which Fulvia owned and controlled property. In Nepos' telling, Antony's enemies sought to seek retribution through the confiscation of his and her property. ${ }^{51}$

Fulvia and the children regularly accompanied Antony abroad while he was hunting Caesar's assassins. She is vividly portrayed by Cicero during her stay at Brundisium. ${ }^{52}$ Faced with a larger army led by Octavian, Antony retreated to Transalpine Gaul. The resulting agreement made Octavian consul with Lepidus and Antony. The three agreed to be appointed triumvirs for five years. Fulvia is also cited as acting in concert with her husband, allowing her daughter Clodia to be given in marriage to "cement the reconciliation" between Octavian and Antony as they established the Second Triumvirate. ${ }^{53}$ Additionally, Fulvia took a leadership role in the proscriptions of the Second Triumvirate in $43 \mathrm{BCE}$, including helping Antony decide who to spare and hearing the pleas of the family members of the proscribed. Many of her most descriptive episodes are set during the proscriptions, and all have been spun to cast her in a negative light. The most extreme of vignette of Fulvia describes her alleged role in the proscription of Cicero. ${ }^{54}$

\footnotetext{
${ }^{49}$ Suet., Aug., 10-12; Plut., Vit. Ant., 17.

${ }^{50}$ Nepos, Att., 9.2-.7.

${ }^{51}$ Ibid.

${ }^{52}$ Cic., Phil., 13.18.

${ }^{53}$ Plut., Vit. Ant., 20.1.

${ }^{54}$ App., B. Civ., 2.3, 6.59; Dio, 47.8.4.
} 
Though Fulvia also famously slammed her door in the face of the city's matrons led by Hortensia when they came in search of tax relief, her most notable and most debated accomplishments took place from 41-40 BCE ${ }^{55}$ After the battles at Philippi, Antony, ${ }^{56}$ with minimal help from Octavian, defeated Brutus and Cassius. As reward Antony was given the governorships of Cisalpine and Transalpine Gaul and the eastern empire. Among his first tasks in the east were reestablishing political alliances with Eastern monarchs like Pharaoh Cleopatra VII. While Antony was away from Rome Fulvia maintained his position in Rome, and according to Cassius Dio, Fulvia was truly consul, and Lucius Antonius, the true consul, was her puppet. ${ }^{57}$

The rallying of troops and siege at Perusia were related, for the most part, by Appian. Octavian returned to Rome to confiscate land in order to fulfill a promise to his Philippi veterans in an attempt to turn men against Antony. ${ }^{58}$ In an attempt to counter Octavian, Fulvia brought her children before the Antony's veterans (or brandished a sword while barking orders), and begged them not to abandon their former general. Lucius fortified Perusia in an effort to hold out until Gallic support legions could arrive. ${ }^{59}$ Fulvia waited out the two-month siege at nearby Praeneste. After Lucius' surrender, she took her children and fled to Greece in order to meet Antony. There, after a final and heated meeting, she succumbed to an unknown illness. ${ }^{60}$

As this brief biography illustrates, Marcus Tullius Cicero is responsible for Fulvia's initial entries into the annals of history through his attacks on Clodius, Curio,

${ }^{55}$ V. Max., 8.3.

${ }^{56}$ Plut., Vit. Ant., 10.3-5.

${ }^{57}$ Dio, 48, 4.

${ }^{58}$ Ibid., 5.1.3.

${ }^{59}$ Ibid., 5.4.32; Dio, 48.15.1.

${ }^{60}$ Plut., Vit. Ant., 30.5; App., B. Civ., 5.7.62, 6.59. 
and Antony. Each of these men had been Cicero's political enemy. Cicero had objected to Clodius' plebian adoption and then testified against him, documenting his enmity during the Bona Dea trial. ${ }^{61}$ After the murder of Clodius, it was Cicero who defended his murderer in open court. It was Cicero cross-examining Fulvia and slandering his memory to her face. ${ }^{62}$ Cicero was the one who, on more than one occasion, accused her of prostitution, infidelity, and possessing a bloodthirsty nature. He is the one who initially immortalized her as Fulvia, The Cruel and Greedy ${ }^{63}$ Nepos presents a much fairer portrait of Fulvia but her inclusion in his works is minimal to say the least. It is Cicero's portrait of Fulvia that is used as the inspiration for Appian and Plutarch.

Because of the layers of propaganda heaped on Fulvia's actions, early historiography reflects the quest to uncover her intentions and the extent of her machinations. There is the desire and tendency to project her workings with Antony's career back upon her unions with Clodius and Curio in order to explain the men's similarities and to fill in the gaps of her biography. Babcock explains this tendency saying "There is indeed enough similarity of action and even method in the careers of her husbands to suggest quite strongly that this woman whose ambition was to 'rule a ruler' may have played a vital if not publicly recognized part in all three careers." ${ }^{34}$

\section{Conclusion:}

\footnotetext{
${ }^{61}$ Cic., Att., 1.6: "When I called myself as witness, you must have heard from the shouts of Clodius' supporters how the jury rose in a body and surrounded me, pointing to their bare throats as if offering their lives to P. Clodius in exchange for mine."

${ }^{62}$ Cic., Mil., 10.

${ }^{63}$ Cic., Phil., 2.5, 2.95, 10.24, 13.18; Cic., Att., 14.11.

${ }^{64}$ Babcock, 20 analyzes how Fulvia was perceived during her own time; Taylor, Delia, Virlouvet, Pomeroy, all support Fulvia having had an active role in Republican politics.
} 
The general narrative of Fulvia's life in modern scholarship stems from a handful of Roman histories: Cicero's Philippics, Plutarch's Life of Antony, Velleius Paterculus' The Roman History, Appian's Civil Wars, and Valerius Maximus' Memorable Deeds and Sayings. These accounts will be dissected in chapters 3 and 4 . None of these authors wrote contemporaneously with Fulvia's life, none was interested in including elements or vignettes from her life in order to leave biographic evidence of Fulvia as an individual. Her character is a plot device meant to embody the chaotic zeitgeist of the last days of the Republic. Her character is meant to explain the defeat and damnatio memoriae of a Roman hero. Her character is meant to justify the moral legislation of the new Augustan regime. Interpretations of Fulvia by modern scholars have been shaped not only by the source material but by the presence of Fulvia in the cultural narrative of popular history and literature. Ultimately Fulvia only exists within the sources and the many forms she takes are created and distorted by those who wrote of her and by those interpreting the sources. This does not mean that her presence is empty or that assessing the many forms her character has taken is futile. Fulvia has remained an exempla in many forms over the centuries, being adapted and accessed by generations of historians and authors within academia and in the popular press. Chapter two closely follows Fulvia's marriage to Antony in the histories of Plutarch, Appian, Velleius Paterculus, and Valerius Maximus as told by biographers of Antony. It assesses how modern biographers have interpreted Fulvia's role the wife of the notorious Marcus Antonius. 


\section{CHAPTER 2}

\section{FULVIA THE WIFE OF ANTONY}

Fulvia's marriage to Antony marks the rebirth of her presence in the historical narrative. Plutarch's Life of Antony in Parallel Lives provides the most elaborate extant account of Fulvia as an individual with character traits beyond those expected of and implied by her status as a Patrician matron. It is from this source that the images of Fulvia as ambitious and controlling originate. Fulvia as a masculine androgyne, a virago, is born from Plutarch's brief introduction:

For Antony put away his reprehensible way of living, and turned his thoughts to marriage, taking to wife Fulvia, the widow of Clodius the demagogue. She was a woman who took no thought for spinning or housekeeping, nor would she deign to bear sway over a man of private station, but she wished to rule a ruler and command a commander. Therefore, Cleopatra was indebted to Fulvia for teaching Antony to endure a woman's sway, since she took him over quite tamed, and schooled at the outset to obey women. ${ }^{1}$

There are many elements at play in Plutarch's choice of phrasing and the visuals he wanted this passage to evoke but none of his choices were inspired by Fulvia herself. She is a supporting character and foil in the story of Antony, yet in three sentences Fulvia's historical fate was sealed. This chapter examines the context and sources influencing Plutarch's Life of Antony and its impact on Fulvia's presence in the preeminent biographies of Marc Antony by Arthur Weigall and Eleanor Huzar in comparison with

\footnotetext{
${ }^{1}$ Plut., Vit. Ant., 10.3.
} 
popular biographies by Jack Lindsay and Pat Southern. ${ }^{2}$

L. Mestrius Plutarch of Chaironeia, Greece, was born between 40-50 CE and gained Roman citizenship through the patronage of the Roman governor Mestrius Florus. As an adult he served as a priest at Delphi, and traveled to Asia, Rome, and Alexandria. He wrote extensively on human morality and history between 90-120 CE. His work Parallel Lives connects prominent Greek figures with what Plutarch considered be their Roman counterparts. The Lives were most likely written together in groups and span from mythological foundations of Greece through the end of the Republic - the Life of Antony is the last. The first writer to use them extensively as a source is Aulus Gellius (ca. $177 \mathrm{CE}$ ) then the historian Athenaios (ca. $223 \mathrm{CE}$ ). Modern preservation of both the Moralia and Lives is thanks to Byzantine scholar Maximos Planoudes (c. 1255-1305.) The initial French translation of Plutarch's body of work was made by Jacques Amyot in 1559. An English translation from Amyot's French was introduced by Thomas North in 1579 as Lives of Noble Grecians and Romanes. It was this edition used by Shakespeare for his interpretations of Coriolanus, Julius Caesar, and Mark Antony. ${ }^{3}$

Parallel Lives were written not only as a collection of moralistic biographies but as a political tool to connect or align Roman and Greek ideas and ideals in an

\footnotetext{
${ }^{2}$ Arthur Weigall, The Life and Times of Marc Antony (Garden City NY: Garden City Publishing Company, Inc. 1931); Eleanor G Huzar, Mark Antony: A Biography, (Minneapolis: University of Minnesota Press, 1978); Jack Lindsay, Marc Antony: His World and his Contemporaries, (George Routledge and Sons, Ltd., 1936); Patricia Southern, Marc Antony: A Life, (Gloucestershire, UK: Anberly Publishing, 2012). There is another 'recent' biography of Antony that will not be reviewed: Alan Roberts, Mark Antony: his Life and Times, (Worcestershire: The Malvern Publishing Company, 1988) but it is out of print and was marked from its initial reviews as a failure of scholarship and biography that provided no value to historiography. See Joseph Geiger, "Book Review: Mark Antony: His Life and Times," The Classical Review, 40.1 (Jan., 1990): 179-180.

3 Tim Duff, Plutarch's Lives: Exploring Virtue and Vice, (Oxford: Clarendon Press, 1999): 1-3; Leofranc Holford-Strevens, Aulus Gellius, (Chapel Hill: University of North Carolina Press, 1988,) 80-81, 198.
} 
increasingly Roman world in which being called 'Greek' was an insult. In order to achieve these ends Plutarch employs philosophical and rhetorical tools to emphasize his moral and didactic narratives. ${ }^{4}$ Writing under the reign of Hadrian, Plutarch was nostalgic for a Republican Rome which was thought to be the classical age during his lifetime. The collapse of the Republic and transition to Empire was a popular theme among writers of all genres. As expressed in Cato Major 4.2-3 and 18.2, Plutarch supports the theory that there was a decline in Roman morality that led to the end of the Republic. ${ }^{5}$ Exploration of moral decline is one aspect of Plutarch's histories that made them readable and popular enough to be preserved and translated.

During the seventeenth and eighteenth centuries "it was self-evident for people of this time that the function of history and biography was to inculcate moral virtues in the reader." ${ }^{\circ 6}$ Plutarch's style easily mirrored Francis Bacon's 1605 Advancement of Learning, which stressed "humanity and calmness" in the face of chaos. Different Lives were popular with different intellectual sets: revolutionaries in Europe favored Timoleon and Dion. The American founders favored Cato Minor, Brutus, and Cicero. Plutarch's blending of narrative with anecdote is cited as a major source of literary biography as a genre. $^{7}$

For Plutarch the primary job of a biographer is to present the character of the subject. The 'Great Deeds' of an individual are used as the backbone of the story supplemented by anecdotes to show the person's everyday personality. The secondary

\footnotetext{
${ }^{4}$ C.P. Jones, Plutarch and Rome (Oxford: Clarendon Press, 1971), 104 argues that an additional purpose of Lives was diplomatic, to equalize Greeks and Romans, "to show the Greeks that the Romans were not savages."

${ }^{5}$ C.P. Jones, Plutarch and Rome, (Oxford: Clarendon Press, 1971), 99.

${ }^{6}$ Duff, Plutarch's Lives, 4.

${ }^{7}$ Ibid., 4-5.
} 
goal was to understand the subject's character and to judge him morally. The overall goal was to have the reader improve his (or her) own moral character after assessing the figures' actions in comparison with the reader's self-assessment of hypothetical action. Judge the subject (Antony for example), judge yourself, and improve. Lives were "moral theory" in practice. For Greeks a person's character "had an ethical element, conceived of in terms of right and wrong, virtue and vice, in terms of conformity to or divergence from moral norms, and this was revealed by deeds." ${ }^{\prime 8}$ Inner ethics and/or thought are not measured as deeds are. It was thought that government, public, or military success or failure were clear representations of character and morality. In the Lives of Alexander and Caesar, Plutarch advocates education as the core goal of history and outlines his criteria for moral success as military and political action coupled with personal deeds. For Plutarch, personal relationships and interactions within personal networks have more moral weight than public action. Therefore, well known actions of Plutarch's biographical subjects are summarized for context, while anecdotes, stories, and jokes get detail and depth. This is the formula for Plutarch's "character impression" or the encomia, "the signs of his soul."

Plutarch claims the strength of his evidence is drawn from his attention to small details and events that were overlooked by other writers. He claims his portraits are designed to "shape the life of each man." His shaping of literary portraits via anecdote shapes the reader through character building. ${ }^{10}$ The goal was for the reader to recognize the morally sound historical characters and emulate their virtues, to consider daily 'what

\footnotetext{
${ }^{8}$ Duff., Plutarch's Lives, 10-13.

${ }^{9}$ Ibid., 15.

${ }^{10}$ Ibid., 17.
} 
would Plato or Cicero do in my situation?' This is Plutarch's way of guiding his readers through the Platonic/Aristotelian concept of mimesis or mime/imitation. This was originally proposed by Aristotle to be the core function of tragic poetry, but Plutarch argues that it extends to biography, using his Lives as evidence. Demetrius and Antony are the only examples of the lives of 'bad' or failed men; a negative example was justified by Plutarch as having an equal potential for mimesis as a positive one, since one could recognize what not to do and strive to imitate any of the actions of the good men the reader had already been exposed to. ${ }^{11}$ In the introduction to Demetrius Plutarch stresses this point:

And the most perfect arts of all--temperance, justice, wisdom - do not consist of judgments about fine, just and useful things alone, but also about harmful, shameful and unjust things. So these arts do not praise the innocence that plumes itself in its inexperience of evil, but they consider it silliness and ignorance of what those who intend to live correctly ought to know. ${ }^{12}$

The emphasis stresses not to emulate the behavior but to use knowledge of bad acts to reinforce good ones. ${ }^{13}$ A long introduction detailing the need for negative examples may have been in response to Valerius Maximus, who claimed that a work on vices and negative aspects of deeds at its core would not be effective as didactic work. ${ }^{14}$ For Plutarch the self-destruction of Antony was proof of the truth of Plato's theory of greatness, that "great natures produce great vices as well as great virtues." ${ }^{15}$ Duff argues that Plutarch sought to highlight elements in Antony's story that proved his potential

\footnotetext{
${ }^{11}$ Duff, Plutarch's Lives., 38-45.

${ }^{12}$ Plut., Demtr., 1.4.

${ }^{13}$ Ibid., 1.6 Plutarch uses an anecdote about Spartans forcing helots to drink to demonstrate the dangers of drinking to their young as he sets up the tales of Demetrius and Antony the "base and castigated."

${ }^{14}$ Duff, $48-9$.

${ }^{15}$ Plut., Demtr., 1.6.
} 
was ruined through lack of character and "perverted through a bad environment."16

The impact of Plutarch's purpose, moral disposition, and sources he used to build the narrative dynamics of his parallel Greek and Roman biographies cannot be understated. It is proclaimed by Plutarch in his introduction that Antony's tale, in comparison with that of Demetrius, is a tragedy in which an up-and-coming noble Roman general who had everything (including the physical presence of Hercules), destroyed his own legacy and his own life through frivolity, excess, corruption, weakness in marriage, and intemperance. "Both become equally addicted to sex and drink, they behaved like common soldiers, they became munificent, extravagant, and arrogant, and they gained similarities in fortune accordingly." 17 Plutarch's assessment of Antony focuses on demonstrating his moral corruption through examples of his generosity/decadence and his history of not only making questionable alliances with questionable characters like Curio and Clodius but also seeming to fall prey to controlling personalities, particularly those of women like actress Volumina Cytheris, his wife Fulvia, and Pharaoh Cleopatra VII.

Plutarch's Antony is impulsive, debauched, and simply not appropriately Roman or noble in his speech or dress. His oratorical style is described as "Asiatic" and his personal style was overtly Greek to draw attention to his Herculean ancestry as a descendant of Anton. ${ }^{18}$ From the outset Antony is cursed with a noble bloodline but a father destructively lousy with money and possessing no ambition. His mother Julia runs

\footnotetext{
${ }^{16}$ Duff, Plutarch's Lives, 45; C.P. Jones, Plutarch and Rome, 105-6, Comparison or paring of figures was a Greek rhetorical device also used by Roman historian Marcus Varro and Cornelius Nepos, both likely sources for Lives.

${ }^{17}$ Plut., Comp. Demtr. Ant., 1.1-3.3.

${ }^{18}$ Plut., Vit. Ant., 2.4-.5, 4.1-.2; Plut., Demtr., 1.8. This is also a topic Cicero dwells on repeatedly: Phil., 2.5.11; 3.6.13.
} 
the household with a control and precision that causes the elder Antony to cower and hide his misdeeds. Young Antony "gave brilliant promise, they say, until his intimate friendship with Curio fell upon him like a pest." ${ }^{19}$ Curio was irresponsibly wild and it is implied that he required this disposition from Antony as well. He encouraged Antony into large debts with Curio as his backer until the Elder Curio, his father, found out and forcibly ended the friendship. Antony then turned to Clodius:

"The most audacious and low-lived demagogue of his time, in the violent courses which were convulsing the state; but he soon became sated with that miscreant's madness and fearing the party which was forming against him, left Italy for Greece, where he spent some time in military exercises and the study of oratory." 20

This friendship waned, as did his friendship with Curio, when Antony left to study in Greece. It was shortly before Antony left Rome that Clodius and Fulvia wed.

After taking a military post in Egypt under Gabinius, Antony joined Caesar in Gaul, stopping briefly in Rome. Antony's public activities and rumors of his private ones are a central theme in Cicero's personal letters as well as his Philippics. Cicero is another core source for Plutarch, and is often referenced directly to support Plutarch's assertions, such as his claim that Antony was as responsible as Caesar for instigating the civil war. He writes that Antony's bombastic speeches and instigation of senate discontent during discussions of dismantling the legions of both Caesar and Pompey, combined with his theatrical flight from Rome afterwards made Antony "as much the cause of the civil war as Helen of Troy was of the Trojan." ${ }^{21}$ Plutarch redeems Caesar from being persuaded or offended on Antony's behalf, but one questions the inclusion of this inflammatory quote

\footnotetext{
${ }^{19}$ Plut., Vit. Ant., 2.3. The level of intimacy between these friends is debated.

${ }^{20}$ Plut., Vit. Ant, 2.4; Cic. Phil., 2.8.

${ }^{21}$ Cic. Phil., 2.22.
} 
if not to infer that Caesar's may have taken offense or that supporters of the optimate cause may have relished Cicero's jab at Antony's masculinity with his colorful allusion. ${ }^{22}$ According to Plutarch the source of enmity between Antony and Cicero lay in Cicero's condemnation and execution of Antony's step-father Cornelius Lentulus for allegedly participating in Cataline's conspiracy. ${ }^{23}$

This does not stop Plutarch from relying on Cicero as a core source of his later Lives, so much so that noted historian of Plutarch C.B.R. Pelling claims that the first thirty chapters of Antony are lifted directly from the second Philippic. ${ }^{24}$ Plutarch's likely reliance on Cicero for source material directly influences Plutarch's description of Fulvia. The works openly contain references to Cicero, Valerius Paterculus, Velleius Maximus, Florus, Cornelius Nepos, Livy, and Sallust. ${ }^{25}$ According to de Wet, Plutarch used Suetonius' Lives of the Caesars and Cicero's Philippics at the core of his research. ${ }^{26} \mathrm{He}$ also references some of Antony's own compositions including, "Replies to Philippics," and three other lost speeches. In turn, Cicero himself had often referenced Antony's letters, as did Ovid, Tacitus, and Suetonius. Plutarch cites Antony himself in Life of Antony 2.2 and $10.2^{27}$ Plutarch may have also used Antony was a second-hand source through Cicero who cites him in Philippics 2.5.11; 3.6.13; 6.2.2; 20. Cicero's Philippics are evident in Plutarch as they were used to anecdotal effect to highlight elements of Antony's character, including his bombastic personality and desire to bend himself to

${ }^{22}$ Plut., Vit. Ant., 6.1. Additionally, he preferred the company of his soldiers and "other men's wives." ${ }^{23}$ Plut., Vit. Ant., 2.1.

${ }^{24}$ C.B.R. Pelling, "Plutarch's Method of Work in the Roman Lives" in Essays on Plutarch's Lives. Ed. by Barbara Scardigli. (Oxford: Clarendon Press, 1995): 297.

${ }^{25}$ B.X. de Wet, "Contemporary sources in Plutarch's Life of Antony," Hermes 118 B\&H 1 (199): 80.

${ }^{26}$ B.X. de Wet, "Contemporary sources in Plutarch's Life of Antony," 81-3.

${ }^{27}$ Ibid., 83-4. Antony's letters were used by Cicero in Att., 10, 10.10.1-2, 13. Ovid, Ex. P.1.123; Tacitus AO.434; Suet., Aug., 7.1, 16.2, 63.2, 69.2,70. Plutarch may have also read Antony's "De ebrietate sua" (Concerning my Drunkenness) available only in reference in Pliny's Natural History, 14.148. 
Fulvia’s liking. ${ }^{28}$

However, Antony tried, by sportive ways and youthful sallies, to make [Fulvia] even more lighthearted. For instance, when many were going out to meet Caesar after his victory in Spain, Antony himself went forth. Then, on a sudden, a report burst upon Italy that Caesar was dead and his enemies advancing upon the country, and Antony turned back to Rome. He took the dress of a slave and came by night to his house, and on saying that he was the bearer of a letter to Fulvia from Antony, was admitted to her presence, his face all muffled. Then Fulvia, in great distress, before taking the letter, asked whether Antony was still alive; and he, after handing her the letter without a word, as she began to open and read it, threw his arms about her and kissed her. These few details, then, out of many, I have adduced by way of illustration. ${ }^{29}$

Plutarch's use of Cicero's invective and anecdotal evidence potentially created for

invective use shape the character of Fulvia in Antony. The intent of the above

'illustration' was not to endear Antony and Fulvia's romance to the reader. Cicero related

this scene as a rhetorical device to highlight Antony's failure as a Roman and a soldier

when he returned from Caesar in Spain and went straight to Fulvia, uncaring that rumors

in Rome were of a Caesarian defeat. Cicero claims that Antony's frivolity and gregarious

nature did not make him wholly beloved and so Plutarch echoes him:

This course naturally made him odious to the multitude, and to men of worth and uprightness he was not acceptable because of his life in general, as Cicero says, nay, he was hated by them. They loathed his ill-timed drunkenness, his heavy expenditures, his debauches with women, his spending the days in sleep or in wandering about with crazed and aching head, the nights in revelry or at shows, or in attendance at the nuptial feasts of mimes and jesters. ${ }^{30}$

${ }^{28}$ B.X. de Wet, "Contemporary sources in Plutarch's Life of Antony," 88-9. Plutarch describes Antony's writing as "emotional and excessive" like his oratory and stresses that Antony was loved by soldiers and "hated by men of worth and sound judgement."

${ }^{29}$ Plut., Vit. Ant., 10.4-5.

${ }^{30}$ Plut., Vit. Ant., 9.3; Cicero, Phil., 2.6 also includes "and what instance was it not of moderation to complain of the conduct of Marcus Antonius, and yet to abstain from any abusive expressions? especially when you had scattered abroad all relics of the republic; when everything was on sale at your house by the most infamous traffic; when you confessed that those laws which had never been promulgated, had been passed with reference to you, and by you; when you, being augur, had abolished the auspices, being consul, had taken away the power of interposing the veto; when you were escorted in the most shameful manner by armed guards; when, worn out with drunkenness and debauchery, you were every day performing all sorts of obscenities in that chaste house of yours." The reference to 'the chaste' house used in a sarcastic manner like this would have also been a slight at Fulvia, whose duty it was to control the estate. 
Plutarch's adaptation of source material like the Philippics into biography of Antony create an enduring portrait of Fulvia. The next section explores how Plutarch and Cicero have been interpreted by biographers of Antony and how, in turn, those biographers have written Fulvia as a character.

\section{I: Not Fit for Spinning}

Many of Antony's qualities that so irk Cicero can be interpreted in a more positive light: wanton expenditures can be understood as generosity, carousing with the infamous of Rome shows that Antony is not hindered by the strict class divides of his time. His promiscuity is a love of women. The first modern biography of Antony, based on Plutarch and Cicero, by archeologist, Egyptologist, and biographer Arthur Weigall shows Antony as lovable, vivacious, good natured, good intentioned, and unambitious. ${ }^{31}$ Weigall claims that Antony was a tragic figure abused by circumstance, and the ambitions of more powerful personalities, rather than his own failings. His Antony is "tender-hearted, sentimental...he stands out as one of the few notable vehicles of occasional human dealing in a savage and immensely cruel age." 32 For Weigall, Fulvia is part of that cruelty, the ambitious force behind Antony. Where he is forgiving, she is callous; where he is soft-hearted, she is bloodthirsty. Though Weigall critically assesses source comments on Antony's character, he does not give Fulvia such benefit. Weigall's The Life and Times of Marc Antony uses Fulvia to explain the negative events in

\footnotetext{
${ }^{31}$ Arthur Weigall, The Life and Times of Marc Antony (Garden City NY: Garden City Publishing Company, Inc. 1931), 108-9. Weigall is also very generous with his treatment of Clodius saying in that Clodius was loved by Romans but destroyed by history, that he was "certainly not the startling specimen of intermediate sex which his once girlish face might lead us to suppose him to have been." (132).

${ }^{32}$ Ibid., 108.
} 
Antony's rise to power and his Triumviral position. It is Fulvia who turns Antony away from Rome towards Cleopatra, eventually costing him his Roman glory and his life.

Weigall's narrative sets the precedent for biographies of Antony in terms of content and format. Weigall begins with Roman political history through the fall of the Gracchi and the schism between the optimates and populares under Marius and Sulla. Caesar is a populist hero and more importantly, Antony's hero. When Fulvia makes her entrance into this tale, Antony is on the outs with Caesar for nearly killing Dolabella in the middle of the Forum. Curio is dead after falling at Utica and Fulvia decides Antony is someone with potential who simply needs proper guidance. Fulvia does not make this known to Antony himself but to Caesar, who all but orders Antony to wed her. Caesar did as Fulvia asked because she was pretty; Fulvia, who was "restless, scheming, domineering" and Antony, the "simple, good-hearted giant," married in the year 46. Fulvia was about 30 and Antony was $37 .{ }^{33}$ This was also the year Cleopatra came to Rome with Caesarian for Caesar's quadruple triumph. ${ }^{34}$ Fulvia is the link between Caesar, Curio, Clodius, and now Antony. It is she who repaired their public standings and offered monetary support. Antony could not stop Fulvia's machinations. She wanted to marry him, to repair his relationship with Caesar, and to make him the second man in Rome. He had no choice. ${ }^{35}$ Here Weigall connects to Cicero's interpretation of Antony's marriage and the "cloaked messenger incident. ${ }^{36}$ Cicero cites Fulvia as encouraging Antony to go to Spain to reconcile with Caesar. In joy over the reconciliation and in

\footnotetext{
${ }^{33}$ These dates and ages are no longer accepted. Fulvia and Antony are both cited as having been born between 83-80; their marriage may have taken place as early as 48 since their son Antyllus was born in 47.

${ }^{34}$ Arthur Weigall, Antony, 127, 167, 190.

${ }^{35}$ Ibid., 191.

${ }^{36}$ Ibid., 193-9.
} 
repayment to Fulvia, Antony rode back to Rome, wrote her a love letter declaring fidelity and pretended to be a servant. Cicero, of course, relates this story as a mark against Antony and his character. By Cicero's reckoning, Antony recklessly snuck into Rome, making everyone think Caesar had been defeated by the last Pompeian forces in order to kiss his wife because her plan was successful. Antony was then called in to explain himself before the Comitia. Weigall says that the incident was blown out of proportion because Cicero had no sense of humor; however, Weigall also uses the incident as evidence of Fulvia's control over Antony.

Fulvia 'the ambitious' is not content to control public affairs through Antony; she also spends her personal time scheming. When Cleopatra returns to Rome a second time with her baby it was shortly after the birth of Fulvia's and Antony's son Antyllus (little Antony the archer). Weigall hypotheses that Fulvia and Cleopatra spent time discussing their babies and that Fulvia was "a more interested politician than mother, and was more concerned with Cleopatra's doings in the field of intrigue than in the nursery." ${ }^{37}$

During that year's senatorial break in May, Antony went south recruiting allies, settling veterans of Caesar on homesteads, and countering the malicious (private) speeches of Cicero against him. Rome was secure because of Fulvia and his brothers Lucius, a tribune, and Caius, Praetor, both of them "useful" but "of no great distinction." It was Fulvia who worked effectively and politically for Antony. She was the influential factor and mastermind behind the restoration of King Deiotarius. Weigall stresses that Antony's recruitment of wealthy, influential allies around the bay of Naples was successful professionally but disastrous personally because, away from Fulvia's watchful

\footnotetext{
${ }^{37}$ Weigall, Antony, 202.
} 
eye, he lost all self-control and drank himself into stupor every night. He regularly threw raging parties at author and historian Marcus Varro's house, which he seized, for Caesar's veterans and any political or interesting hangers-on who wished to attend Weigall believes that in order for Antony to turn to Cleopatra, there must have been an event that ended Antony's affection for Fulvia. He believes that Antony and Fulvia's estrangement began on Antony's part because of her behavior during executions after the revolt at Brundisium. Fulvia had accompanied Antony to greet some Macedonian legions he had recalled without knowing that Octavian had to written several officers he was acquainted with from his time in Greece. Those officers refused to follow Antony and called him a traitor. Antony was outraged but Fulvia was more so. She cursed them gleefully while standing very close during their executions. She wanted no mercy. The event shows Fulvia "in an hysterical condition, and screaming her imprecations at the men who were being butchered; she approached so close to them as they died that she was drenched with their spurting blood." Antony, however, was too "cultured, sensitive...easy going and humane" for all that bloodshed and began to lessen his contact with Fulvia. ${ }^{38}$

After the battle of Mutina, the organization of triumvirate becomes the most pressing issue for Antony and Fulvia: Antony was the most influential and powerful as he

\footnotetext{
${ }^{38}$ Weigall, Antony, 250-1. This scene follows Cicero, Phil., 3.4 "And although it is not possible to requite him with all the thanks to which he is entitled, still we ought to feel all the gratitude toward him which our minds are capable of conceiving. For who is so ignorant of public affairs, so entirely indifferent to all thoughts of the republic, as not to see that, if Marcus Antonius could have come with those forces which he made sure that he should have, from Brundisium to come, as he threatened, there would have been no description of cruelty which he would not have practiced? A man who in the house of his entertainer at Brundisium ordered so many most gallant men and virtuous citizens to be murdered, and whose wife's face was notoriously besprinkled with the blood of men dying at his and her feet. Who is there of us, or what good man is there at all, whom a man stained with this barbarity would ever have spared; especially as he was coming hither much more angry with all virtuous men than he had been with those whom he had massacred there?"
} 
had already run Rome independently twice. Weigall believes that the marriage alliance between Octavian and Clodia must have been suggested by Octavian as it favored him, because he inherited the respect of Clodius' followers, but the alliance made no positive impact on Antony. Once the terms of the triumvirate were agreed upon, Antony, Octavian, and Lepidus turned their attention to proscriptions: the triumviral list of republicans to be executed and have their property confiscated. Here Weigall follows Plutarch's description: Antony wanted Cicero most for his Philippics and for the death warrant against himself and Lepidus. Many were added to the list, some allegedly because of their wealth. Weigall, does, however, elaborate on the elation of the mob which felt that wealth should be confiscated and he stresses repeatedly that Antony was the most likely of any of the triumvirs to offer pardon. After describing the circumstances of Cicero's death, Weigall turns from his core sources Plutarch, Cicero, and Livy to Cassius Dio to provide narration for the frequently mentioned story of Fulvia and her hair pins. Plutarch does address Antony's role in proscriptions in Antony 20-21 but he does not indict Fulvia in any way.

According to Dio, it was Octavian who was merciful. Antony and Fulvia were vengeful, avaricious, and took delight in wielding authority over life and death.

But Antony killed savagely and mercilessly, not only those whose names had been posted, but likewise those who had attempted to assist any of them. He always viewed their heads, even if he happened to be eating, and sated himself to the fullest extent on this most unholy and pitiable sight. And even Fulvia also caused the death of many, both to satisfy her enmity and to gain their wealth, in some cases men with whom her husband was not even acquainted; at any rate, when he saw the head of one man, he exclaimed: "I knew not this man!" When, however, the head of Cicero also was brought to them one day (he had been overtaken and slain in flight), Antony uttered many bitter reproaches against it and then ordered it to be exposed on the rostra more prominently than the rest, in order that it might be seen in the very place where Cicero had so often been heard declaiming against him, together with his right hand, just as it had been cut off. 
And Fulvia took the head into her hands before it was removed, and after abusing it spitefully and spitting upon it, set it on her knees, opened the mouth, and pulled out the tongue, which she pierced with the pins that she used for her hair, at the same time uttering many brutal jests. ${ }^{39}$

In describing the delivery of Cicero's head and right hand to Antony, Weigall writes that Antony laughed and declared the proscriptions over, while Fulvia "was more savage than her husband," spitting on Cicero's head and stabbing the tongue with her hair pin because of its slander against Antony — not any slight against herself. Weigall uses this example to alleviate Antony of guilt for the death of Cicero and explains away the prevalence of the wealthy proscribed saying that the proscriptions were actually well tolerated because they were a reversal of Sulla's, in which the populares and their supporters were purged.

Antony and Lepidus were allowed to be merciful as leaders secure in their reputations and positions, while Octavian had to be ruthless because he had been associated with Cicero and the republican elite. He hypothesizes that because Fulvia was described as greedy according to Cicero, that the idea stuck around long enough (specifically until Cicero had become more popular and esteemed after his death) to be used to vindicate the men involved in an unsavory situation. ${ }^{40}$

Settling into the rule of Rome as a triumvir, Weigall claims that Antony was pleased with all but being back with Fulvia since "he can hardly have been happy in sharing his home with so forceful and so violent a woman,' in whom 'there was nothing feminine but her figure,' as Velleius says; ${ }^{41}$ and "whose ambitions for his ultimate

\footnotetext{
${ }^{39}$ Dio, 47.8.1-4.

${ }^{40}$ Weigall, Antony, 290-7; Plut., Vit. Ant., 21. "In a word, Caesar's power, which proved to be anything rather than a tyranny so far as his own course was concerned, was brought into odium by his friends; and of these Antony, who had the greatest power and was thought to be the greatest transgressor, incurred the most blame."

${ }^{41}$ Vell. Pat., 2.74.
} 
autocracy gave him little rest." ${ }^{42}$ Weigall entirely discounts Velleius, saying that his histories are entirely Augustan and cannot be trusted as evidence of Antony in any way because they lean towards a 'divine' view of Cicero. Despite this Weigall uses Velleius as a justification for his theory of Antony and Fulvia being estranged. ${ }^{43}$ Until he leaves for Philippi, Antony allegedly distances himself from Fulvia by resuming his consummate party schedule and striving to be even more generous than before he became triumvir. At Philippi Antony was, once more, likely to pardon the captured and was known for his benevolence, especially in comparison to Octavian who was known to spare none and leave the executed unburied. ${ }^{44}$

After the battle Antony had planned to go to Gallia Narbonenses (Lepidus' province) after first touring through Syria, Greece, and Asia Minor (because these areas had previously housed republican forces) to search for remnants of Brutus and Cassius' party, replace officers, collect funds. Weigall claims none of these actions were the true motive, but that this travel was necessary for Antony to stay away from Fulvia. In the very next line he contradicts this theory by supposing that Antony was completely content to leave Rome in the knowledge that Octavian could hold no sway in Rome while Fulvia was there supporting Antony's cause. Everyone was under her command, so too would Octavian be. Because Octavian was already ill and shamed for his lack of leadership and prowess on the battlefield, Antony must have been convinced that Octavian would flounder and die: "either he would die in a natural death at no distant date, or Fulvia would strangle him, metaphorically or actually." ${ }^{45}$ So Antony was over-

\footnotetext{
${ }^{42}$ Weigall, Antony, 300.

${ }^{43}$ Ibid.

${ }^{44}$ Ibid., 313-5.

${ }^{45}$ Weigall, Antony, 316-7; Dio, 48.4.
} 
joyed at leaving for the East: optimistic, victorious, popular, untouched by Philippics, able to leave both Fulvia and Octavian, the "masterful" and the "sinister." Weigall presents them as equal concern to be equally dismissed, Octavian as too weak, Fulvia as too strong. ${ }^{46}$

Antony would eventually make his way to Alexandria to look for resources and to avoid going home. Weigall also believes that Antony chose to go to Alexandria not out of romantic desire, but in believing that Cleopatra could provide the funds needed to settle issues in Italy. Antony wanted to create an alliance and a plan for Caesarian in Caesar's memory. ${ }^{47}$ Within months of his winter stay in the Egyptian capital, land disputes began in earnest in Italy. Octavian miraculously recovered from his illness and took charge of settling veterans, though he had no funds to do so since Antony had to return with the Eastern tribute. And so Octavian decided to confiscate landed estates and force owners to supply farmers as they transitioned from a military life to a rural one.

Lucius Antonius was consul and refused to condone this action, believing it was viewed by the public as being sympathetic to aristocracy. Lucius and Fulvia wanted Antony to settle the issue so the issue stalled until the soldiers rebelled and seized lands on their own. Fulvia supported them but remained firm in wanting Antony to settle the soldiers on farms and meet their needs. Weigall claims Fulvia's support was only based opposition to Octavian. This hatred was exaggerated by Octavian's divorce of Fulvia's daughter Clodia. ${ }^{48}$ Antony also may have received word that Fulvia was the primary

\footnotetext{
${ }^{46}$ Weigall, Antony, 318-21.

${ }^{47}$ Ibid., 332-4.

${ }^{48}$ Weigall, Antony, 327-8; App. B. Civ., 5, 3.19; According to Dio 48.3, “Antony's soldiers, and Octavius also, blamed him [Lucius] for working against Antony's interests, and Fulvia blamed him for stirring up war at an inopportune time, until Manius maliciously changed her mind by telling her that as long as Italy remained at peace Antony would stay with Cleopatra, but that if war should break out there he would come back speedily. Then Fulvia, moved by a woman's jealousy, incited Lucius to discord."
} 
instigator of the political fallout so that he would have to return and to force his hand against Octavian. Octavian with his own rebelling veterans had forced Lucius to fortify Perusia while Fulvia held Praeneste as commander, dressed in armor and brandishing a sword. ${ }^{49}$

Octavian claimed to be openly fighting, not against Antony, but against Fulvia and Lucius, who turn claimed to be fighting for Antony and not for themselves. Octavian painted Lucius and Fulvia as opposed to the ideals of the Caesarian/populares party and claimed that Antony "must have been furious with Fulvia and Lucius." Weigall notes that as far as Antony was concerned "one may suppose that his intention was to hasten back to Italy, to repudiate his wife," and settle all matters using Cleopatra's money. Antony finds out that his wife "may have ruined his prestige in Rome." 50 After surrendering, Lucius' and Antony's officers were pardoned and ordered to retire, while local leaders and subordinate soldiers were ruthlessly executed. Octavian went to Rome, seized control, executed Lucius and Fulvia's supporters, then used the resources gained from the executions to settle veterans. Everyone in Rome desperately wanted Antony and the moderation that came with him to return. Fulvia "escorted" by 3000 Gallic cavalry to Brindisi "breathing fiery threats of vengeance." 51

\footnotetext{
${ }^{49}$ Weigall, Antony, 336; Flor., 2.16.5-6 "Though the nature of Antonius was always evil, on this occasion his wife Fulvia, girding herself with the sword of her husband's service, egged him on yet more." Florus is certainly not sympathetic to Antony or his supporters, saying, "Antonius by himself was a sufficient menace to peace and to the State." Dio, 48.10.3-4, "The others were elated at this, and since they were winning over those who had lost their land, Lucius went about in every direction organizing them and detaching them from Caesar, while Fulvia occupied Praeneste, and with senators and knights for her associates was wont to conduct all her deliberations with their help, even sending orders to whatever points required it. And why should anyone be surprised at this, when she would gird herself with a sword, give out the watchword to the soldiers, and in many instances harangue them, all of which gave additional offence to Caesar?"

${ }^{50}$ Weigall, Antony, 337-9.

${ }^{51}$ Ibid., 340-2. On wanting Antony back, Weigall quotes Suetonius, Aug., 15, saying Octavian was unpredictable and cruel; that he rarely slept or ate and that he had unnatural perversions and was "addicted to common rape or adultery."
} 
Plutarch himself had not wasted much effort in explaining the conflict, nor did he see a need to question Antony's role in the affair:

While Antony was indulging in such trifles and youthful follies, he was surprised by reports from two quarters: one from Rome, that Lucius his brother and Fulvia his wife had first quarreled with one another, and then had waged war with Octavius Caesar, but had lost their cause and were in flight from Italy; and another, not a whit more agreeable than this, that Labienus at the head of the Parthians was subduing Asia from the Euphrates and Syria as far as Lydia and Ionia. At last, then, like a man roused from sleep after a deep debauch, he set out to oppose the Parthians, and advanced as far as Phoenicia; but on receiving from Fulvia a letter full of lamentations, he turned his course towards Italy, at the head of two hundred ships. On the voyage, however, he picked up his friends who were in flight from Italy, and learned from them that Fulvia had been to blame for the war, being naturally a meddlesome and headstrong woman, and hoping to draw Antony away from Cleopatra in case there should be a disturbance in Italy. ${ }^{52}$

For Plutarch, Fulvia is the wholly the cause and had started the war to draw Antony away from Cleopatra. The events following Fulvia's arrival in Greece are varied in detail and there is dispute among Plutarch, Appian, and Dio as to whether Fulvia and Antony met in Athens or Sicyon, whether they parted amicably or as estranged, and as to Antony's response to Fulvia's death. Plutarch is of the opinion that Fulvia's death absolves Antony of any guilt and that a marriage alliance with Octavia is in the best interest of all parties. Appian believes that Antony blamed his brother Lucius and has Lucius respond to these accusations in a speech to Octavian that claims Fulvia had intended to make Antony king of Rome, saying,

"I knew that Fulvia was in favor of the monarchy, but I joined with her and made use of my brother's soldiers to overthrow all of you. And now if my brother should come to dissolve the monarchy I would go to join him, either openly or secretly, and would fight you again in behalf of the country, although you have been a benefactor to me. If he seeks allies to assist him in maintaining the tyranny, I will fight on your side against him as long as I think that you are not trying to establish a monarchy. I shall always set my country above gratitude and above family." ${ }^{33}$

\footnotetext{
${ }^{52}$ Plut., Vit. Ant., 30.1-2.
}

${ }^{53}$ App., B. Civ., 5.6.54. 
Where Dio has Fulvia violently confront Antony about Cleopatra, Antony attacked back over Perusia; they separated. Fulvia went to Sicyon near Corinth "abandoning herself to despair, caring not whether she lived or died." ${ }^{54}$ Appian simply has Antony leave her in Sicyon to deal with the pressing military issues of Octavian's victory and Lucius' surrender, rather than battle with words. ${ }^{55}$ To restore peace to Italy Antony was willing to reconcile; Octavian said "Fulvia was the enemy of peace." She died, there was no suspicion about her conveniently timed death. Octavian then agreed to reconcile after Antony placed one hundred percent of the blame on Fulvia. As a result, Octavian ruled Italy, Dalmatia, Spain and Gaul. Antony was made Eastern autocrat and gained the legions of the recently deceased Calenus, bringing his total to eighteen legions. ${ }^{56}$ Antony was also required to marry Octavia to cement the reconciling; Weigall theorizes that compared to the "masterful" Fulvia and the intriguing Cleopatra, Octavia must have been disappointing and "bovine." He also alleges that Antony would have hated home life with Octavia because "passive feminine goodness can be exceedingly exasperating." It was also around this time that his twins with Cleopatra were born, so Antony was generally unhappy. ${ }^{57}$ The ramifications of Antony's life and death in Alexandria as the consort of Cleopatra will be considered in depth in chapter 4.

\footnotetext{
${ }^{54}$ Plut., Vit. Ant., 30.3-4. "It happened, too, that Fulvia, who was sailing to meet him, fell sick and died at Sicyon. Therefore, there was even more opportunity for a reconciliation with Caesar. For when Antony reached Italy, and Caesar manifestly intended to make no charges against him, and Antony himself was ready to put upon Fulvia the blame for whatever was charged against himself. .." Weigall, Antony, 343. ${ }^{55}$ Dio, 48.28.2; App., B. Civ., 5.6.55-6.

${ }^{56}$ Dio, 48.28.3-4. "And although Antony was held responsible for her death because of his passion for Cleopatra and her wantonness, nevertheless, when this news was announced, both sides laid down their arms and effected a reconciliation, either because Fulvia had really been the cause of their variance hitherto or because they chose to make her death an excuse, in view of the fear which each inspired in the other, inasmuch as the forces which they had, as well as their ambitions, were equally matched."

${ }^{57}$ Weigall, Antony, 347-8.
} 


\section{II: Fulvia the Manager of Men}

The good-hearted but inept Antony of Weigall's The Life and Times of Marc Antony is held to a higher standard of accountability for his actions and shortcomings in Eleanor G. Huzar's Mark Antony: A Biography. ${ }^{58}$ Like Weigall, Huzar focuses on using primary Roman and Greek accounts to create a narrative life of Antony in context and is also favorable towards Antony's motives. Unlike the lovable galoot Weigall describes who is cursed by circumstance to repeatedly make the wrong choices in crucial instances Weigall describes, Huzar's Antony is an able administrator and military tactician who is unsuited for political endeavors without guidance. Huzar argues that Antony's domestic and foreign policies were not only moderate and thoughtful, but integral to Rome's transition to a stable empire. ${ }^{59}$ Huzar also argues that Fulvia was a positive force in Antony's life who helped guide his political career and manage his behavior.

Huzar begins by describing the pressures young Antony was under to balance his potential family circumstances in the current political atmosphere with the expectations of his family status. Antony's grandfather, also called Marcus Antonius, was proscribed by Marius in $87 \mathrm{BCE}$. He was an orator favored by Cicero and his head was placed on the Rostra following execution. Antony's father, Marcus Antonius Creticus, was an "amiable incompetent" described like Antony: good looking, overly generous, unable to properly use public funds, regularly bankrupt. Though he failed in his task of defeating pirates hunting the waters off the coast of Cilicia, he was able to negotiate a treaty with them but was killed in Crete in $71 \mathrm{BCE}$. Though Marcus Antonius Creticus had died in somewhat

\footnotetext{
${ }^{58}$ Eleanor G. Huzar, Mark Antony: A Biography, (Minneapolis: University of Minnesota Press, 1978.)

${ }^{59}$ Ibid., 2-11, 151-168,173-184.
} 
ill-repute, the political ties he made, including one with Julius Caesar, who served as Creticus' legate, would serve the younger Antony well. ${ }^{60}$

Huzar paints Antony's transition to adulthood as one in which he strives to fulfill the duties of a man of this rank and station but emotionally or intellectually unable to do so. He wants to be involved in political affairs as his father and grandfather had been, but is guided by emotion and opportunity. His 'gang of incorrigibles' Clodius and Curio were not only spend thrift rabble-rousers but politically engaged in causes that offered Antony opportunity to avenge his family's failings. Antony from the start worked with Curio and Clodius because they were enemies of Cicero. Curio worked with Crassus' money for Clodius' acquittal in trial of the Bona Dea affair. As tribune, Clodius exiled Cicero for his role in the executions of Catalinarian conspirators like Sura. Antony may have helped Clodius pull down Cicero's house to build a shrine to Libertas after that exile. It is these factions and affiliated networks that set and shape Antony's career, not Fulvia. Antony, throughout his life maintained a close alliance to Curio but his connection to Clodius waxed and waned. Huzar alleges that the strain on their relationship was caused by Clodius' marriage to Fulvia. She follows Cicero's accusation that as early as 59/58 Antony and Fulvia had begun an affair. Huzar finds this believable because Antony marries Fulvia immediately after divorcing his wife Antonia in $48 .{ }^{61}$

Marriage to Fulvia helped Antony exploit his best qualities and suppress the aspects of his personality that often worked against him. Huzar writes that military service also suited Antony's talents but also led to his downfall because, for a person of Antony's status, it was not possible to separate military aspiration from political power.

\footnotetext{
${ }^{60}$ Huzar, Antony, 14-16.

${ }^{61}$ Ibid., 24-6.
} 
Caesar and Fulvia helped Antony negotiate the political aspects of his career. ${ }^{62}$

By the time Fulvia had wed Clodius, Curio and Antony were already building their careers as patrician populares against increasingly oligarchic optimates (who were working hard to court Pompey by the time Antony and Fulvia were wed.) During this stage in his career Antony had been working to rise through the political ranks with guidance from Caesar. ${ }^{63}$ Between 50-49 BCE, Antony ran for election as both Tribune and Augur. He was elected as Augur, a lifelong appointment. Curio was outgoing the Tribune at the end of $50 \mathrm{BCE}$ and campaigned for Antony against Lucius Domitius Ahenobarbus. And so, by the end of 49 Antony was augur, tribune, and propraetor with imperium. By 47 he was also master of the horse with imperium (or as Huzar calls it, 'Henchman to the Dictator.') This position lasted one year, he was replaced by Marcus Lepidus. ${ }^{64}$

Under Fulvia's guidance Antony was able to regain Caesar's trust and was once again made master of the horse with imperium. Huzar states that their marriage was one of true love and that Fulvia's "dominant characteristic was her drive for and manipulation of political power." This is an interpretation of Plutarch's Antony 10.3 in which Fulvia's ambition is to "rule a ruler and command a commander." In order to "rule a ruler" Fulvia must make Antony into one. Fulvia had the track record to do so having, "encouraged both her previous husbands' politically active careers." ${ }^{65}$ Huzar claims that Fulvia was

\footnotetext{
${ }^{62}$ Huzar, Antony, 27-8.

${ }^{63}$ Ibid., 45; Plut., Vit. Ant., 5.1; Cic., Phil., 2.4; Antony previously competed against Cicero in 53 BCE for a position as augur to fill position opened by the death of Quintus Hortensius the orator.

${ }^{64}$ Huzar., Antony, 42, 54-5; Plut., Vit. Ant., 6.2; App., B. Civ., 2.41. A Propraetor had the powers of praetor with extended terms, they controlled provinces. According to Cicero, de Leg. 3.3, Praetors were patrician magistrates responsible for the administration of justice. Under Caesar's guidance, Antony was made propraetor of Italy with imperium despite having never served as praetor. This meant he could keep his military command and operate as a sort of third consul.

${ }^{65}$ Huzar, Antony, 70. "Fulvia was a manager, and Antony was manageable."
} 
successful in her ambitions in shaping Antony since it was clear that when he was "led by Cytheris, he had been reckless and wanton; [but] living with Fulvia, he almost won control of the Roman world." 66

For Huzar, Antony does not rise to his full potential after the death of Caesar, because despite Fulvia's efforts, he makes mistakes. Antony does not try to win over the people of Rome when he is most in position to do so. Lucius Antony was far more of a true Roman demagogue than his brother Marcus. Antony was viewed as a moderate working with both the Senate and the people of Rome. He also committed a number of faux pas that prevented him from having the full support of the people as a demagogue. He alienated elements of the populace by using Roman troops to restore order and to execute people he claimed were enemies of the state. Antony also refused to allow Caesar to be deified and worshiped. Despite this, his popularity never waned among the army or army veterans. ${ }^{67}$

According to Huzar, Fulvia is ever present in Antony's political dealings. When “King” Deiotarus of Galatia paid ten million sesterces to keep his title after illegal takeover, Huzar muses that it was "perhaps engineered by Fulvia." ${ }^{68}$ Likewise the engagement between Octavian and Clodia was also "engineered” by “ambitious” Fulvia. Huzar describes the death of Cicero as earned because of the Philippics but reports that his head and right hand were "delivered to Antony and Fulvia who treated them contemptibly and then, nailed them to the Rostra in the forum." 69

\footnotetext{
${ }^{66}$ Huzar, Antony, 76-7.

${ }^{67}$ Ibid., 84-6. Antony executed Gaius Amiatus, a demagogue, who had been exiled and returned after Caesar's death.

68 Ibid., 90.

${ }^{69}$ Ibid., 120.
} 
Though initial veteran settlement issues in Italy began shortly after Caesar's death when Lucius Antony was in control of the program, according to Huzar, the Perusine War was entirely part of Fulvia's machinations. Huzar states that "Fulvia still emerges as the driving force in the events of 41-10 BCE" even if all questionable character attributes (greed, jealousy, etc.) are cast aside. This narrative follows Velleius, Appian, and Dio. In his account of the conflict, Velleius does not focus so much on Fulvia's role in instigation in any way, but describes her as Fulvia the wife of Antony, "who had nothing of the woman in her except her sex, was creating general confusion by armed violence." ${ }^{70}$ For Velleius, Lucius Antony and Antony's lieutenants Plancus and Asinius Pollio, who raised seven legions to join with the eight that Lucius and Fulvia raised, are noted as the main Antonian actors. In this account, Fulvia seems to have just been getting in the way while brandishing her sword and swearing rather than actively organizing as she is portrayed doing in Appian and Dio. ${ }^{71}$ Huzar portrays Fulvia as acting in concert with Lucius to protect Antony's interests. She meets with him one last time in Athens and dies without reconciliation. Huzar hypothesizes that Antony would have felt responsible and must have known that he had lost a guiding hand since Fulvia had provided Antony with ambition, "much of his brutality, and even part of his steel."72 The narrative then follows Antony turns his full attentions to Eastern conquest and administration, attempting to use Cleopatra as his guiding force since he cannot rule alone and Caesar and Fulvia are lost to him.

Eleanor Huzar revisited the impact that Fulvia had on Antony almost ten years

\footnotetext{
${ }^{70}$ Vell. Pat., 2.74.

${ }^{71}$ Huzar, Antony, 89, 118-120, 132-3.; Vell. Pat., 2.74.2-3; App., B. Civ., 5.4. 29-33; Dio, 48.27.

${ }^{72}$ Huzar, Antony, 135.
} 
after Mark Antony: A Biography in "Mark Antony: Marriages vs. Careers," in which the author dissects how developments in Antony's career progressed in relation to each of his five marriages. ${ }^{73}$ Huzar again begins by setting Fulvia up as the driving force behind Antony's successes because she was intelligent, she was beautiful, and she gave him two legitimate sons. However, Fulvia is described repeatedly with negative attributes that were absent from Huzar's references to her in Mark Antony. Fulvia is described as "a relentless virago." ${ }^{74}$ Cicero is praised for his deft take down of Fulvia in the Philippics in which he alleges that she was a greedy prostitute prone to savagery. Huzar proclaims "Fulvia's reputation is still grimy from the mud so effectively thrown by Cicero.", In discussing the proscriptions Huzar follows Appian, Valerius Maximus, and Dio. Appian describes Fulvia's actions during the proscriptions but does not mention her as contributing to role the death of Cicero. He focuses instead on her greed and the bloodshed it brings:

Rufus possessed a handsome house near that of Fulvia, the wife of Antony, which she had wanted to buy, but he would not sell it, and although he now offered it to her as a free gift, he was proscribed. His head was brought to Antony, who said it did not concern him and sent it to his wife. She ordered that it be fastened to the front of his own house instead of the rostra. ${ }^{76}$

Appian also relates the story of Hortensia, daughter of Hortensius the orator, who was so rebuffed by Fulvia that she marched into the forum and spoke forcefully to the triumvirs concerning the women of Rome being taxed. ${ }^{77}$ Huzar uses this example as evidence that

\footnotetext{
${ }^{73}$ Eleanor G. Huzar, “Mark Antony: Marriages vs. Careers,” The Classical Journal 81, 2 (Dec. 1985-Jan. 1986): 97-111. In succession Antony was married to a freed woman Fadia until he left Rome for Greece; then married his cousin Antonia while serving Gabinius; after divorcing her in 49 BCE he married Fulvia; after Fulvia's death in 41/40 he married Octavia; finally, he married Cleopatra in 36 BCE.

${ }^{74}$ Huzar, "Marriages vs. Careers," 100.

${ }^{75}$ Ibid., 101.

${ }^{76}$ App., B. Civ., 4.29.

77 App., B. Civ., 4.32-4.
} 
Fulvia was far more shrewd and less likely to be cowed than Antony. When the women of Rome complained to Antony he submitted but Fulvia slammed her door in their faces, ordering them to leave. This difference is what Huzar believes made Fulvia the true match for Octavian rather than Antony; Fulvia wanted to build an empire while Antony was content to rule only the East. ${ }^{78}$ The Perusine War, in this telling, has Fulvia in full armor acting as "commander-in-chief of a military force," and directly giving orders to Sextus Pompey to seize North Africa in Antony's name. ${ }^{79}$ Once again, Fulvia is described as the source of Antony's ambition and brutality. Huzar ends Fulvia's influence on Antony by quoting Shakespeare's Antony, who mourned Fulvia's death by wishing for another wife in her image. ${ }^{80}$

\section{III: Comrade Fulvia}

Biographies of Antony and the representations of Fulvia they contain are not the realm of scholars alone, but shared themes enjoyed by popular audiences. Jack Lindsay, biographer and writer of historical fiction (and ardent communist), published Marc Antony: His World and His Contemporaries in 1939, only a few years after Arthur Weigall's The Life and Times of Marc Antony. ${ }^{81}$ Lindsay's biography focuses on the political circumstances of Antony's life while painting both Caesar and Antony as bourgeoisie champions for the proletariat of Rome against the capitalist optimates seeking to keep Rome an oligarchy built on the backs of the working poor. Lindsay also

\footnotetext{
${ }^{78}$ Huzar, "Marriages vs. Careers," 101-2.

${ }^{79}$ Ibid., 102.

${ }^{80}$ Ibid., 103.

${ }^{81}$ Jack Lindsay, Marc Antony: His World and his Contemporaries, (George Routledge and Sons, Ltd., 1936); Arthur Weigall, The Life and Times of Marc Antony, 1931.
} 
claims that this work was a necessary response to 1936 speeches by Mussolini and Hitler in which each leader claimed to be following in the footsteps of Caesar. Lindsay hoped to show that they were unlike Caesar and his party, who were interested in "free productivity and actualizing internationalism." ${ }^{82}$ This biography of Antony of all modern biographies of the Roman leader is the most influenced by the political and intellectual ideologies prevalent in the cultural context in which it was produced. Interestingly, Lindsay only uses Marxist description of economic and social classes in Rome when discussing broad concepts: the division of political classes, agrarian policies, veteran land settlements, proscriptions. He does not apply ideological labels to individuals nor use them to interpret motives or intent. Unlike Weigall and Huzar, who relied on Plutarch as the core narrative source and used sources like Cicero, Appian, and Dio to supplement scenes or events when Plutarch was silent or unsatisfying in detail, Lindsay relies on Cicero's Philippics, the trials Pro Milione, Pro Caelio, Oratio in Catilinam, and letters Ad Atticus. In fact, until Cicero's death takes place, Cicero is far more present and relevant in Lindsay's Rome than Antony.

The narrative begins with Rome driving headlong towards class war between the moneyed elites and the impoverished proletariat. Antony's family is described as middling bourgeoisie with a history for working towards social change. Antony, as a young man, is only interested in "derisive hedonism." The material luxury of the Roman wealthy, with their lives of leisure is described in second person, as though you are a young Roman man living a world where "women were merely something that possessed the faculty of giggling when tickled." Lindsay is often prone to both romanticize scenes

\footnotetext{
${ }^{82}$ Lindsay, Marc Antony, xi.
} 
and mix genres. ${ }^{83}$ It is often difficult to recognize Marc Antony: His World and His Contemporaries as a history or biography of Marc Antony. There is a great deal of quoted dialogue paraphrased from Cicero's letters, and segments of the book are in epistolary format. Antony is not the focus of his own biography until he allies with Cleopatra. Fortunately, Fulvia is a character in this drama and several of the key events in her life are discussed in relation to their effect on Rome and on Antony.

Fulvia is first mentioned as part of the aftermath of the Bona Dea affair. Lindsay describes the event through the eyes of Cicero as prosecutor of Clodius. Antony allegedly tried to seduce Fulvia and was forced to leave Rome by Clodius, "his bosom-friend." Antony is described as having "his greatness lay in a warm simplicity," in a man being "blundering yet sensitively able to detect the living heart of mass loyalty and surrender to it." He was bearded, tall, thickly muscled, full of "sheer maleness," but lacking Caesar's "sensual" lips. ${ }^{84}$ Fulvia is not described as having any sort of character, attribute, or personality until after her marriage to Antony. Lindsay describes at great length the rise of Curio in Caesar's political shadow in a chapter titled "The Age of Parliamentary Cretinism," but does not discuss Antony's career until Caesar is made dictator. ${ }^{85}$ The story then follows Cicero as he vacillates between the Pompeians and the Caesarians. After Curio is killed in Africa and Antony returns to Italy after Pharsalus, (neither military engagement is discussed in detail) Antony and Fulvia wed.

Fulvia is described as "a person of strong and fearless resolution, long used

\footnotetext{
${ }^{83}$ Lindsay, Marc Antony, 39-41. The book was well-received at the time as a work for general audiences. G. I.C, "Reviewed Work: Marc Antony: His World and His Contemporaries by Jack Lindsay," Greece \& Rome 6, No. 17 (Feb., 1937): 123.

${ }^{84}$ Lindsay, Marc Antony, 81-2.

${ }^{85}$ Ibid., 124-132.
} 
to political tumults, she ... roused him from his inertia of resentment." Antony had been left in Italy when Caesar pursued battle in Spain. Lindsay claims Fulvia put him on the path to reconciliation with Caesar but was so upset that he started seeing his former consort, Volumnia Cytheris, again. This alleged infidelity is the reason Lindsay believes that Antony sneaks back into Rome to surprise Fulvia. He had to perform a humbling and grand gesture in order to earn her forgiveness. ${ }^{86}$ After Antony is made consul and Fulvia has given him a son, she was able to spend time "enjoying herself, satisfying her lust for land and property." This may be a reference to Appian 4.4, in which Fulvia is accused of having Antony add a man to the proscription list because she wanted his house. ${ }^{87}$

Lindsay does not delve into any detail concerning the Triumviral proscriptions that eventually took the life of Cicero, but he describes "confiscatory legislation" to "equalize wealth" and the "expropriation of the moneyed-class." He ends the issue by saying "Cicero was killed." There is no mention of the roles of the individual triumvirs, nor Fulvia, nor explanation as to why the subject is not treated with the depth customary to a history of Rome. The Perusine War finally causes Lindsay to read Plutarch and cite him. Lucius and Fulvia decide to gain all of Italy in Antony's name. If "Fierce Fulvia" did not actually wear a sword "she wore one in spirit." Lindsay also relies on Dio, claiming that Fulvia had been "ruling Rome with a high hand" while the triumvirs were away. Antony decided he liked carousing in the East and did not miss her domination, so

\footnotetext{
${ }^{86}$ Lindsay, Marc Antony, 181-2. There is no evidentiary basis for this theory. Cicero in Philippics, 2.24 accuses Antony of treating the courtesan and freedwoman as equal in dignities to his mother, a Roman matron, and for being Tribune but consorting with mimes, actresses, jugglers, and other infamous people. Lindsay has the chronology wrong. Antony's term as Tribune was at an end when he married Fulvia.

${ }^{87}$ Ibid., 200-3. Also V. Max., 4. 5. 4. "The man was Cæsetius Rufus, a senator, was brought to Antony while he was sitting at a banquet, and that all the others turned away their faces. "Antony ordered that it [severed head of Rufus] be brought nearer, and, after looking at it carefully for some time, and while all were waiting to hear what he would say, he remarked: 'I have never known this man."'
} 
she decided to stir up trouble that he could not ignore and force his return to her. ${ }^{88}$ The failure of the siege and Fulvia's death allow Antony's attention to turn to Cleopatra. He remains under her sway for the remainder of his narrative life. Never again does Lindsay remark on Fulvia's life, death or her impact on Antony.

\section{IV: Fulvia the Desperate Housewife}

Patricia Southern's Mark Antony: A Life, is part of a series on Roman history and personalities that includes biographies of Julius Caesar, Augustus, Empress Zenobia, Domitian, and Cleopatra. She has also published a combined biography of Antony and Cleopatra, Antony \& Cleopatra: The Doomed Love Affair that United Ancient Rome \& Egypt. ${ }^{89}$ Mark Antony, anti-hero for a modern age, is the theme of Mark Antony: A Life. Southern's introduction presents Antony a written character: as an idea, a legend, that has been given so many variable facets by Cicero, Plutarch, Appian, and Shakespeare that Antony can be a figure for all ages, recreated and remade in the whatever tragic, comic, or romantic image is necessary to connect with a desired audience. This is of course true of Fulvia as well. Southern does not carry this theme through her own biography, it is a concept given as part of the rationale behind writing a new biography of Antony. Her take on Antony is very millennial. Antony is so overwhelmed with the responsibility of his place in the world, that he regularly does nothing in the face of crisis. Similarly, Fulvia is written as a woman involved in schemes and politics to relieve her boredom and

\footnotetext{
${ }^{88}$ Lindsay, Marc Antony, 221-2; Dio, 48.4-5.

${ }^{89}$ Patricia Southern, Mark Antony: A Life, (Gloucestershire: Amberley, 2012); Julius Caesar, (Tempus, 2007); Augustus, (Routledge, 2001); Empress Zenobia: Palmyra's Rebel Queen, (Hambledon Continuum, 2009); Domitian: Tragic Tyrant, (Tempus, 1997); Cleopatra, (Tempus, 1998); Antony and Cleopatra: The Doomed Love Affair that United Ancient Rome \& Egypt, (The History Press, 2009). There is also a series on the Roman army and several survey works on general Roman Imperial history.
} 
domestic discontent.

The narrative begins at its ending, with Antony dead after Actium and the siege of Alexandria and sets about exploring how a man of promise met this end. Southern briefly sets the political circumstances of Antony's youth and Rome at large. As a young man Antony is portrayed as acting with little to no logic, gambling, drinking, reckless, with "reprobate friends," enjoying "profligate behavior," and having an "addiction to wine" that make him entirely unreliable. ${ }^{90}$ Despite this description of his actions and behavior, there is very little sense of Antony as a character. Southern's interpretation of him is stripped of a core personality; his actions are listed; they are not described in a way that infers motive or interpreted by the author. Antony is an anti-hero because he should have succeeded. Given his family circumstance and the political support he was given, combined with his military victories, he should have been a hero not a suicide. Unlike, Weigall's Antony who was too good for this world, broken by the cruelty of his time or Huzar's Antony, who was dependent on the strong to guide him and keep him focused, Southern's Antony is a man who should have the experience and knowhow to make good choices but he doesn't. There is no explanation. He is not willing or able in some aspects to play along with the rules of Roman society and because of this rebelliousness or underdog spirit displayed through seemingly illogical choices, he is a character that modern audiences can identify with and want to succeed. Because Southern does not show or tell readers Antony's motives, she is able to make readers guess at Antony's reasoning based on the idea that he is just not going to make the right choice. This invites readers to remove Antony's thought processes from their historical context so that readers

\footnotetext{
${ }^{90}$ Southern, Mark Antony, 34-42.
} 
can project and identify with his circumstances in a modern context. For example, when discussing Antony's early financial circumstances Southern writes:

Proudly, [Antony] refused to sit in the seats at the theatre reserved for bankrupts while at the same time incurring more and more debts, spending money on unnecessary trivia which enabled him to show off and entertain guests. Anyone who has been in a similar position will know that there comes a point where more debts cease to mean anything. The absolute remoteness of being able to repay any of the money simply invites further recklessness." 91

So Antony from the beginning of his career, is so unambitious in terms of personal success that he has ostensibly given up on striving to meet any of the qualifications of being a successful elite Roman. He is not wholly nihilistic in his decisions; he will accept success it if happens, but he really doesn't care. This sets the stage for Antony to accept and keep people with questionable motives and behaviors in his life, including Fulvia and Octavian.

Fulvia joins the action during the events surrounding Clodius' Bona Dea scandal. Southern believes that Cicero's allegations of an affair with Antony shortly after beginning her marriage to Clodius are valid and are the cause of Antony's break with Clodius and subsequent journey to Greece. She notes that their relationship was based on more than the money she controlled, and that "Fulvia may have attracted him for several more elevated reasons, as well as sex, since he eventually married her and seems to have been fond of her to the point of indulgence." 92 After Antony returns to Rome and reconnects with Fulvia, "the lady of fearsome reputation," he was "devoted to her" according to all sources showered her with "indulgent affection." Those sources are not directly referred to even when closely summarized; for example, the description of Fulvia

\footnotetext{
${ }^{91}$ Southern, Mark Antony, 36-7.

${ }^{92}$ Ibid., 38.
} 
not having the capacity for "spinning and weaving" which echoes Plutarch, Antony, 10.3. Fulvia is then described as woman who wanted to achieve political goals and used her husbands to do so, out of necessity, because she was woman in a man's world. Antony was most likely to succeed so she controlled him the most. "Married to Antony, Fulvia found a new lease of life and an outlet for her restless ambitions, which of necessity included meddling in politics and military affairs." Though Fulvia famously tamed Antony, it was she who should have been "brought to heel." It is a reflection of Antony's lack of direction or desire to act that allows Fulvia's machinations to bring him to the forefront of Roman politics and eventually undermine his credibility. ${ }^{93}$

Southern offers the vignette of Antony as his own messenger to Fulvia, originally in Plutarch 10.4, for two reasons: as an example of Antony's willingness to flout Roman sensibilities by dressing as a slave, and to reveal that Fulvia has a heart after all. Despite Antony's "undignified and extremely unRoman behavior," Fulvia squeals and weeps to find him safe and pledging his love to her. For Southern this scene proves that Fulvia is not wholly "a virago with no redeeming features." Apparently, Fulvia is not completely manly in her behavior because she cries when confronted with romantic gestures.

Southern does not go as far as to praise Fulvia, though, or even really try to make her a sympathetic character. This heartwarming scene ends with the foreboding assertion that though Antony was a sound judge of character he was unable to tell when he should "detach himself from unsuitable associates."

Southern does not mention Fulvia campaigning for Antony during the crisis of succession and Mutina, so the next mention of Fulvia comes from the proscriptions.

\footnotetext{
${ }^{93}$ Southern, Mark Antony, 77-8.

${ }^{94}$ Ibid., 79-80.
} 
"Barbaric" Fulvia using her hairpin to silence Cicero for good is acknowledged as a potential method of shifting blame from Antony (and Octavian) to Fulvia over the death of Cicero since this act is much worse than Antony's desire to see Cicero's hands on the Rostra. Southern cites the whole incident as designed to make a villain of Antony and relieve Octavian of guilt. Even better is to shift that blame off of Antony and on to Fulvia. ${ }^{95}$ The account of Perusia comes directly from Dio, with the recognition that Dio's account of Perusia is "greatly distorted." However Southern does believe, as Dio alleges, that Lucius Antony and the "formidable" Fulvia were actually co-consuls and coconspirators acting against Octavian. Southern muses on the mystery of the degree to which Antony was aware or involved at all in the Perusine War, but she concedes that it was winter in Alexandria during the siege, so it was possible that Antony didn't know.

This is contrary to Dio's claim that Antony callously orchestrated the war, unleashed his general of a wife, and then stayed out of the way until the outcome was known. ${ }^{96}$ Southern then turns to Appian's tale of Antony's man Manius telling Fulvia that only an Italian war will bring Antony home from Egypt, and that she must cause a situation that Antony alone could rectify. Southern believes it plausible that Fulvia would do anything to get Antony back, saying that if Fulvia had been jealous it was/is understandable to us today to be "consumed with justifiable jealousy." ${ }^{\text {"97 }}$ Fulvia's death and its circumstances are matter of fact. On her way to Athens, she and Antony may have fought. Southern focuses instead on Fulvia's legacy in the lives of her children. Little is known about Clodia after Octavian ended their engagement, but the lives and deaths of

\footnotetext{
${ }^{95}$ Southern, Mark Antony, 122.

${ }^{96}$ Ibid., 182-4; Dio, 48.4-5, 24, 25.5.

${ }^{97}$ Southern, Mark Antony, 185-7.
} 
her sons are well documented. Marcus Antonius Antyllus was executed by Octavian in 30 $\mathrm{BE}$ at age fourteen after being dragged from his father's temple of Dionysus in Alexandria, Egypt. Marcus Antonius Iullus was raised by Octavia in Rome and as served as praetor, consul, and Asian proconsul. He was executed in 7 BCE by Augustus for an affair with Augustus' daughter, Julia, a treasonous crime. ${ }^{98}$

\section{Conclusion:}

This chapter has followed Fulvia through biographies of Mark Antony, from the origin of her character in the words of Plutarch, Appian, Dio, and Velleius Paterculus. The motives, literary devices, rhetorical rationale, and cultural considerations of these authors in relation to the depiction of Fulvia as an historical character will be the focus of chapter 4. Chapter 3, "Finding Fulvia," continues exploring Fulvia’s place in historiography but turns away from her as a figure important for being Antony's wife. Interest and scholarship focusing on Fulvia as an individual Roman woman developed in the early 1970s and continues through today. This chapter will survey Fulvia's presence in women's history and how understanding of her life, agency, and political involvement have changed over time.

\footnotetext{
${ }^{98}$ Southern, Mark Antony, 253-4.
} 


\section{CHAPTER 3}

\section{FINDING FULVIA}

Fulvia Flacca Bambula has been a fascination of scholars seeking to build a narrative past in which women were active in the masculine fields of politics and warfare. Fulvia has been derided as a woman out of control created by an age out of control. She has been praised as a politician and military commander of the Roman Republic. How Fulvia has been studied and interpreted by historians has changed over time and has been heavily influenced by changes in historical methodology and trends in scholarship. The concept of Fulvia as a historical woman has taken many forms, from a secondary character in Antony's story, to a political organizer to rival Boss Tweed, and from a simple wife and mother to a fully emancipated woman, military combatant to a purely literary figure. This chapter outlines how women's history and the specific methodologies developed to study Roman women by classicists intersect to influence perceptions of Fulvia. It then presents how research trends have impacted Fulvia in historiography. As a whole, this chapter shows the mechanisms involved in the creation of Fulvia as a historical character by assessing the ideologies behind Roman women in text.

Part I: The Importance of Women's History 
Narratives of Fulvia's life began in earnest during the 1960s and 1970s as women's history grew as an idea and as a field of study. Inspired by social justice movements and feminist ideology, the first comprehensive studies of Greek and Roman women's lives wanted to 'find' women in the historical record and tell their stories. Gerda Lerner, creator of the first women's studies program in the United States, argued that the study of women's history is essential to creating a comprehensive historical narrative. ${ }^{1}$ Historians building women's history still struggle with the idea that not only have women been generally excluded from the historical narrative, descriptions of and ideas about women have been created by men and filtered through male value systems supported by male institutions. ${ }^{2}$ Through the 1980 s historical texts, myths, elegies, invective, graffiti, letters, epigraphy, any and all written traditions were excavated for mentions of women; they were mined for references to women's live, habits, deeds, and personalities. The essays "Did Women have a Renaissance," by Joan Kelly-Gadol, "Defining Feminism," by Karen Offen, together with "Gender Analysis: A Useful Category of Historical Analysis," by Joan Scott, and The Majority Finds Its Past by Gerda Lerner, all attempt to establish a methodology for pulling women's narratives out of male-centered historical texts to find women's history. Of special investigatory importance were women who held positions equal to those of men.

Lerner sought to help define the study and methodology of women's history by outlining the inclusion of feminist theory and noting that simply inserting women into traditional history only demonstrated what men, in any given context, thought women

\footnotetext{
${ }^{1}$ Gerda Lerner, The Majority Finds Its Past (Chapel Hill: University of North Carolina Press, 1979), 125. ${ }^{2}$ Lerner, The Majority, 111; Joan Kelly-Gadol, "Did Women Have a Renaissance?" in Women, History, and Theory: The Essays of Joan Kelly, edited by Catharine R. Stimpson, 19-51, (Chicago: University of Chicago Press, 1984); Karen Offen, "Defining Feminism: A Comparative Historical Approach," Signs 14, (1988): 119-157; Joan Scott, "Gender: A useful Categorical Analysis," The American Historical Review 91 (Dec, 1986): 1053-1075.
} 
should or should not be doing. For scholars studying Roman women Lerner's framework can very rarely be applied because there is so much information about prescribed roles for women and so little information about the actual lives they lived.

This lack of evidence has turned classicist scholars to the study of gender following the model established by Joan Scott. Scott argued that in order to understand societal organization and interaction within a culture at any given time, gender must be analyzed because it is culturally constructed. Gender studies encompass the entire culture and cultural construction of sex and sex roles ${ }^{3}$ and can determine the dynamic between men and women. Scott posited that gender consists of a multitude of factors working together; it is a category socially constructed in relation to power and culture, elemental in kinship relations and subjectively self-constructed in terms of behavior and reconstruction. ${ }^{4}$ Historical inquiry can surmise constructions of masculinity and femininity in relation to each other, institutions, politics, and culture. Gender is applicable as "a primary way of signifying relationships of power" in any historical context. ${ }^{5} \mathrm{By}$ understanding the social and institutional concepts of Roman gender and gender norms, more information can be gathered about the lives of Roman women. Analysis of Fulvia as a woman outside of traditional gender norms and prescribed behavior dominates her historiography.

Gadol-Kelly, Lerner, Offen, and Scott all identified missing categories and definitions crucial to the development of the methodology of women's history. These scholars have provided the field with new interpretations, new application of sources, new language, new focus, and new means of finding women lost to the ages and biased

\footnotetext{
3 Joan Scott, "Gender," 1057.

${ }^{4}$ Ibid., 1067-1068.

${ }^{5}$ Ibid., 1073.
} 
institutions, new purposes, and determination to find them. However, by the end of the 1980s scholars of Roman women's history generally came to the conclusion many of the methodologies applicable to more modern eras were of limited use in Classical history. The belief that women's lives and voices are not accessible through text, a concept referred to as 'silence,' has driven studies of Roman women from traditional philological methodologies to textual and literary theory generally not used by historians. ${ }^{6}$ Texts produced on the study of ancient women and their roles in the historical record are remarkably reflective of the social and political contexts in which they were written. This means that Roman women are 'found' through the study of the context in which they lived.

Women were largely omitted or glossed over in Greco-Roman historiography until the social and political upheavals of the 1960s and 1970s bled into academic and popular historical study. Born as the result of the women's liberation movement, inquiry into 'women in antiquity' began as an attempt to recover histories of women previously uninvestigated or written out of the historical narrative. Scholars and activists were not attempting to justify existing order; they were inspired by the women's liberation movement to seek out the origins of inequality and to prove that women had had an impact on history on a large scale: i.e. in political and military fields. They were looking for women who didn't play by men's rules. Early scholarship of Fulvia reflects the trend of presenting Fulvia as an exception, as a woman who absolutely wielded authority in a time when women were legally and culturally prohibited from doing so.

\footnotetext{
${ }^{6}$ W. Schiedel, "The Most Silent Women of Greece and Rome: Rural Labor and Women's Life in the Ancient World," Part I. Greece \& Rome, 42.2, (Oct., 1995): 202-17; A. P. M. H. Lardinois and Laura McClure, Making Silence Speak: Women's Voices in Greek literature and Society, (Princeton, N.J.: Princeton University Press, 2001.)
} 


\section{II: The Historiographical Construction of Fulvia in Context}

Prior to the incorporation of women's history and its methodological models into Classical studies, views on Roman women were pulled directly from primary sources with little to no critical analysis. Scholars also draw upon outmoded stereotypes of women and ideas about the innate character of women as a group. These elements are evident in early assessments of Fulvia. For example, in Helen E. Weiand's 1917 article "The Position of Women in the Late Republic, Part II," Fulvia is drawn directly from Plutarch and Cicero. Weiand also weaves moralistic opinion throughout her analysis. Fulvia is portrayed as a rival of Cleopatra and the exact opposite of Octavia. ${ }^{8}$ Weiand worships Octavia, saying (to Fulvia's detriment), "If one should wish to find two women to personify all the good, on one hand, and all the evil on the other, of the times, one could not find two better illustrations than the two women last mentioned-Octavia and Fulvia." 9 She states that Fulvia "was the quintessence of almost all the passions that were swaying women of that day - greed, selfishness, thirst for power." Weiand excoriates Fulvia for nearly two pages, saying that she was absolutely pitiless and took pleasure from murder and revenge. ${ }^{10}$ Weiand credits Fulvia with instigating the Perusine War and claims that Lucius Antony just stood around and twiddled his thumbs while Fulvia marshalled the garrisons. Weiand then curiously takes it upon herself to expand on

\footnotetext{
${ }^{7}$ Helen E. Weiand "The Position of Women in the Late Republic. Part II" The Classical Journal, 12.7 (Apr., 1917), 429.

${ }^{8}$ Ibid., According to Weiand: "Cleopatra, of a foreign land, can hardly claim a place in discussion of the women of the Roman Republic."

${ }^{9}$ Ibid., 430.

${ }^{10}$ Ibid.
} 
Velleius' claim that Fulvia was "only a woman in body," 11 and mix his tale with Dio's and with her own opinion in a blended monologue format.

"Fulvia," says Velleius, "had nothing womanly about her except her body;' and circumstances allowed her to revenge that blunder of nature. Warrior-woman," marriage to her was merely a means whereby she might rule through men and over them. Her ambition needed an outward support; she could only murder the defenseless and plunder the down-trodden; when she stepped out independently, her role ended." ${ }^{12}$ [quotation marks original]

From her Weiand shifts away from Fulvia and Octavia to Christian women's activities.

By today's research standards, it is a bizarre article.

The first comprehensive study of a history of Roman women is J.V.P.D.

Balsdon's Roman Women: Their History and Habits, published in $1963 .{ }^{13}$ Balsdon's work was published during the development of specific methodology for women's history. His goal was to present a history of Roman women "notable and notorious alike with a general description of women's life ... particularly of her married and family life." ${ }^{14}$ Balsdon's overall tone is that of a naturalist observing women he has found in the works of Cato and Livy. Balsdon reads the history of Roman women as one of "increasing emancipation" and moral decline ${ }^{15} \mathrm{He}$ is positivist in interpretation and reads texts as representative of reality in all aspects. Balsdon also unhesitatingly makes historicist comparisons like describing women appealing the 198 BCE Oppian law as "behav[ing] like early twentieth-century suffragettes." ${ }^{16} \mathrm{He}$ is entirely unaffected by developments in specific methodology for studying women. His interpretation reflects the first phase of women's history, simply finding them in the sources and reporting it in a

${ }^{11}$ Vell. Pat. 2.74.3

${ }^{12}$ Weiand, "The Position of Women," 431.

${ }^{13}$ J.V.P.D. Balsdon, Roman Women: Their History and Habits (NY: J. Day \& Co., 1963).

${ }^{14}$ Ibid., 9.

${ }^{15}$ Ibid., 10-12.

${ }^{16}$ Ibid., 35 
way that presents women's actions through male frameworks of success. Fulvia is shown

to be warlike and politically active. Fulvia is described briefly in chapter two: "Female

\section{Emancipation:"}

The Amazon of a woman was, in succession, the wife of Clodius, young Curio and Mark Antony. In each marriage, she proved a good wife and became the mother of children. If, during the last four years of her life she developed into a virago, she was at least a loyal virago. After Caesar's murder in $44 \mathrm{BC}$ she was at Antony's side, squandering Caesar's treasure. She was at Brindisi with him in the autumn, watching as the heads of mutinous centurions were lopped off. ${ }^{17}$

Balsdon goes on to add that Lucius Antony was "certainly her subordinate," 18 in conflict against Octavian. Balsdon does not give the reader any additional information about the Perusine war except that Martial describes it and that sling bullets were recovered with inscriptions "on the subject of the Amazon who commanded the besieged." 19 So Balsdon encourages his readers to investigate Fulvia "the Amazon" on their own by accessing these sources without providing any critique or analysis of their content or the image of Fulvia that they create. ${ }^{20}$ Balsdon then quotes Shakespeare's Antony on the spirit of Fulvia as imperious and masculine. He concludes his biographical excerpt by stating that though historians have been unkind to Fulvia it is to be expected: "What language other than obscene vituperation could Cicero employ in description of a

\footnotetext{
${ }^{17}$ J.V.P.D Balsdon, Roman Women, 49. Brindisi is Brundisium. Balsdon uses current Italian city names. ${ }^{18}$ This is drawn from Dio, 48.4

${ }^{19}$ Ibid., 50. Amazons were used as representative of female power in reference of JJ Bachoffen's theory of matriarchy.

${ }^{20}$ Martial, 11.20 is dealt with at length in chapter 4. This epigram is recorded by Marital but thought to have been originally composed by Octavian. It supports Appian's claim that Fulvia declared war out of jealousy and sexual frustration after hearing of Antony's liaisons with the queen Glaphyra and Pharaoh Cleopatra VII. The sling bullets or glandes are the subject of Judith Hallett's "Perusinae Glandes and the Changing Image of Augustus," AJAH 2 (1977): 151-71, also found in chapter 4. The glandes are inscribed with explicit sexual threats against Fulvia describing her anatomy as undesirable and unfeminine.
} 
woman who had Clodius for her first husband and Antony for her last?"21 Balsdon's treatment of Fulvia is due to his direct interpretation of source material as inherently true and a representative description of all aspects of Fulvia's life and personality. It is equally tainted by belief in Cicero's opinions of Clodius and Antony. ${ }^{22}$

The next study of Fulvia focuses on her actions and personality in relation to the control or influence she wielded over Clodius, Curio, and Antony. Charles L. Babcock's "The Early Career of Fulvia" was published in The Journal of American Philology in early $1965{ }^{23}$ Babcock sets the tone for his article with a quote from Lactantius' history of Rome, "How unlucky is that city in which a woman occupies the offices of men?" Fulvia's career, according to Babcock, was political control through marriage that included Clodius and Curio. Previous to his article, contemporary scholarship followed the idea of Fulvia's control of Antony promoted by Cicero and Plutarch; Clodius and Curio were not included in her domination. Babcock, for the most part, reads the texts of Plutarch, Velleius Paterculus, and Valerius Maximus as based in truth and referential of reality in terms of the deeds and personality of Fulvia. Babcock is "not interested in exonerating her of greed and cruelty," merely in proving that she was more politically active than previously accepted through comparison of the political platforms of Clodius and Curio, which he asserts she masterminded. ${ }^{24}$ Babcock states that it is "Fulvia's

\footnotetext{
${ }^{21}$ Balsdon, Roman Women, 50.

${ }^{22}$ Clodius has recently been the subject of scholarship trying to redeem him from Cicero's legacy. Eleanor Winsor Leach, in "Gendering Clodius," The Classical World 94, 4 (Summer, 2001): 335-59, argues that Cicero's treatment of Clodius during the Bona Dea trial, Pro Caelio, and subsequent slandering's in the Philippics were rhetorically based and meant to undermine Clodius' power as a political enemy of Cicero and his optimate party. W. Jeffrey Tatum in The Patrician Tribune (Chapel Hill: University of North Carolina Press, 1999) similarly tries to resuscitate Clodius' image, arguing based on bills and motions based during his tribunate that Clodius was politically astute and dedicated to governmental change.

${ }^{23}$ Charles L. Babcock, "The Early Career of Fulvia." The Journal of American Philology 86 (Jan., 1965): 1-32.

${ }^{24}$ Ibid., 19.
} 
ambition, that impresses itself inevitably as one considers the careers of her husbands and the coincidences of her marriages." 25

Babcock begins with a biographical analysis of Fulvia's social status and marriage desirability, assessing the status her parents, Marcus Fulvius Flaccus Bambulio and Sempronia Tuditani. Babcock also gives histories of the families of Clodius, Curio, and Antony in comparison to Fulvia's status, asserting that though Fulvia was no prize, due to her overbearing personality, she was rich. Her wealth would have been a draw to men working their way up the cursus honorum. Babcock suggests that there was no reason to doubt that Fulvia's father Marcus Fulvius Flaccus Bambalio was wealthy since, "Valerius Maximus suggests that it may well have been true." ${ }^{26}$ Babcock also states that though Fulvia's personal attributes are unknown, based on her coin representations, she was pretty and possessed charm. ${ }^{27}$ In assessing the value of Plutarch's claim in Antony 10.3 that Fulvia had no need for spinning and desired command, and Velleius Paterculus' claim in 2.72.2 that Fulvia had nothing feminine but her body, Babcock states they are "not entirely flattering comments but I accept them as fairly accurately reflecting the will and the interests of Fulvia." Babcock does, however, claim that Fulvia's presentation in "Cicero and Dio are propaganda." 28

Babcock also speculates the Fulvia must have been a serious person, ascribing Plut. 10.4 (Antony as his own messenger to Fulvia) as an attempt to lighten Fulvia's mood. Fulvia's relationship with Antony is a core component of Babcock's thesis. He

\footnotetext{
${ }^{25}$ Babcock, "The Early Career," 23.

${ }^{26}$ Ibid., 4-6. Babcock also suggests that Fulvia may have had a wealthy step-father L. Pinarius Natta. Babcock infers that if Pinarius were Fulvia's step-father, it would make her more desirable to Clodius. This theory was posited by Lily Ross Taylor, who in discussing the election of Pinarius Natta, said the campaign "has Fulvia's characteristic energy." Lily Ross Taylor, Party Politics in the Age of Caesar, (University of California Press, 1961), 139.

${ }^{27}$ Babcock, "The Early Career," 10-12.

${ }^{28}$ Ibid., 19.
} 
begins with the assumption that Fulvia did control Antony and uses aspects of their reported relationship to 'prove' that she also worked her magic on Clodius and Curio. Babcock believes that Cicero's allegations of an affair between Fulvia and Antony are true and uses it to color his perception of the behavior of all the men involved. Babcock states that Antony may have attempted to kill Clodius on his way to join Caesar in Gaul. He also claims that hostility and violence between Antony and Curio against T. Milo indicates Fulvia's direction of their behavior. ${ }^{29}$ After the death of Clodius, when Curio completely ceased connection to Milo, Babcock narrates, "at the risk of excessive romanticism one might suggest a Fulvia involvement (with Antony) against as a source for such a lull in the friendship." 30

Babcock states that Antony and Fulvia's adultery led to their marriage and that Fulvia may have orchestrated Antony's charge against his wife Antonia of adultery with P. Dolabella, leading to their divorce. ${ }^{31}$ Babcock finds the political careers of Fulvia's husbands striking because each chose to be a plebian tribune as a Caesarian and populare. He states that each man also being married to Fulvia, “"who had a woman's body and nothing else," assumes some significance. Babcock uses accounts of Fulvia's activity during the triumvirate to prove that she was also active in Clodius' career, saying that if Fulvia was a military organizer and recruiter, Fulvia must have also overseen Clodius' collegia. ${ }^{32}$ Babcock believes Appian's and Dio's accounts of Fulvia in an active leadership role during the proscriptions but claims there is no way of knowing the degree

\footnotetext{
${ }^{29}$ Babcock, "The Early Career," 12-4. Babcock bases this theory on AC Clark's commentary on Cicero's Pro Milione (Oxford 1895). Clark "assumes that Curio's rejection of Cicero's invitation to aid in Milo's campaign reflects Fulvia's control over Curio in 53." Babcock states that Antony only fought against Milo because "he was already under Fulvia's influence." He does not seem to feel that Antony and Curio would have an issue with Milo murdering Clodius despite their being political allies and friends from childhood.

${ }^{30}$ Babcock, "Early Career," 17.

${ }^{31}$ Ibid., 14.

${ }^{32}$ Ibid., 21.
} 
to which she participated. He then claims that all propaganda is based on reality so if Cicero claims Fulvia is cruel and greedy that "we must expect to find in Fulvia such tendencies." Babcock goes so far as to assign Fulvia the credit for acts her husbands were in charge of; for example, Clodius seizing Cicero's house. Babcock believes that Fulvia must have wanted the property because she "was certainly acquisitive if not avaricious," and that "it is in the area of personal ambition that one can best seek evidence of Fulvia's hand." 33

In discussing the Perusine War Babcock takes the same attitude, again following Appian and Dio. When Appian claims that Lucius Antony calls Fulvia a monarchist for supporting her husband's soldiers, Babcock believes this links Fulvia to individualism and power for herself. Despite claiming to be wary of Dio's propagandistic works, Babcock believes that Fulvia was behind getting senate approval for Lucius Antony's triumph, claiming that this sort of organization would have been par for the course for "Fulvia, a seasoned director of husbands." ${ }^{34}$ Babcock ends his article with an assertion that Fulvia dominated all three of her husbands and imposed her ambitions on Clodius, Curio, and Antony in turn to their detriment and deaths. This echoes Cicero condemning Antony over Fulvia's connection to Clodius and Curio: "But who was ever found before, except Publius Clodius, to find fault with my consulship? And his fate indeed awaits you, as it also awaited Caius Curio; since that is now in your house which was fatal to each of them. ${ }^{35}$ For Babcock, Fulvia's ambition influenced and eventually did in the men she

\footnotetext{
${ }^{33}$ Babcock, "The Early Career," "and what I consider important had taken a hand herself in the control of the affairs."

${ }^{34}$ Ibid., 23-5.

${ }^{35}$ Cic., Phil., 2.5.11.
} 
married, that her "husbands all died valiant deaths as the price of their high goals." 36 Babcock's article "The Early Career of Fulvia" demonstrates the detrimental effects of using primary sources without consideration of the subject as a woman being written about by the male enemies of the political faction assigned to her by her natal and affinal families and their respective socio-political networks.

Sarah B. Pomeroy, in her masterwork Goddesses, Whores, Wives, and Slaves: Women in Classical Antiquity, gives Fulvia's reputation in the historical cannon a much more critical analysis than Balsdon in Roman Women: Their History and Habits, although their monographs are comparable in intent. Pomeroy's scope is much more comprehensive in expanding to Greece and Egypt. It is also neutral in intent and tone, whereas Balsdon is both paternalist and sensationalist. Pomeroy presents textual references from all genres with corresponding archeological support where they exist. She also expands into all strata of Greek and Roman societies while Balsdon sticks to the elite. Fulvia is introduced in a section headed 'Women in Politics.' Though Pomeroy does describe Fulvia as ambitious she presents Fulvia's negative image in Appian, Dio, and Velleius as reflecting her transgressions into the masculine fields of war and politics. $^{37}$

Judith Hallett moved away from defining Fulvia through textual evidence alone in "Perusinae Glandes and the Changing Image of Augustus. ${ }^{38}$ Hallett analyzes sling bullets found at Perusia inscribed with threats against Fulvia in comparison with Martial's epigram 11.20, allegedly written by Octavian during the battle. These sources are closely

\footnotetext{
${ }^{36}$ Babcock, "Early Career," 32.

${ }^{37}$ Sarah B. Pomeroy, Goddesses, Whores, Wives, and Slaves: Women in Classical Antiquity, (New York: Schocken Books, 1975, 1995), 185-9.
} 
read in light of the impact of Augustan rhetoric on literary composition. Hallett's methodology in trying to assess how Fulvia came to be portrayed as a military leader comparable in authority to Octavian employs theory on the construction of gender in terms of ideal forms of masculinity and femininity in context as well as literary criticism of the tropes and devices used in Martial's epigram. ${ }^{39}$

Though Babcock and Hallett are writing a little over ten years a part, are both classicists, and are studying the same woman, Hallett's article reflects her use of the alternate methodologies constructed by Scott and Kelly-Gadol. During the 1970s classicist scholars of women's history were also developing classics-specific guidelines for both locating women in history and interpreting sources that were not womanfocused. Marilyn B. Skinner, a classicist who now specializes in gender and sexuality in the ancient world called for all extant texts to be read with a generalized rule of "close focus. ${ }^{40}$ Barbara McManus outlines rules for engaging in women's history and the first rule is that ancient women's history cannot be positivist. It is theory and conjecture; it deals in ideas not 'fact.' Roman historians have to move away from the idea that there is shame in focusing on non-political aspects of history or the use of anything apart from literary sources. ${ }^{41}$

Hallett's article is remarkable for its early adherence to these new methodologies at a time when they were largely abstained from due to their inherent political

\footnotetext{
${ }^{39}$ Judith Hallett, "Perusinae Glandes and the Changing Image of Augustus." AJAH 2 (1977): 151-71. This text is also dealt with at length in chapter 4. Coin and sling bullet images are included in the appendix beginning on page 187 .

${ }^{40}$ Marilyn B. Skinner, ed., "Rescuing Creusa: New Methodological Approaches to Women in Antiquity," in Special Issue of Helios 13 (Lubbock: Texas Tech University Press, 1986): 1-5.

${ }^{41}$ Suzanne Dixon, Reading Roman Women: Sources, Genres, and Real Life (Duckworth: London, 2007), 19-22.
} 
undertones. ${ }^{42}$ Hallett assesses the implications of the sling bullets and Octavian's sexual threats and innuendo towards Fulvia in terms of gender in the late Republic. During the late 1970s there was a shift towards gender studies (and away from merely finding women through positivist interpretation) because it can be applied as "modified structuralism," i.e. the study of the function of ancient peoples and their societal structures as hierarchies and mechanisms in an ancient machine. When the roles of men and women are aligned with the roles of cogs and gears, gender roles in ancient societies can be viewed objectively. This viewpoint does not focus on the construction of gender, merely the effects. Texts are not referential but can be used to interpret societal norms and values. ${ }^{43}$ Within the circles of scholars of women in the ancient world the influence of Joan Kelly-Gadol's theories about gender as a means of analysis in context led to attempts to study women under Augustan reforms.

In Catherine Virlouvet's "Fulvia: The Woman of Passion," Virlouvet sought to present a narrative biography of Fulvia as political figure. ${ }^{44}$ She builds upon Babcock's notion that Fulvia was the connection between the political policies of Clodius, Curio, and Antony. Virlouvet maintains that Fulvia herself was politically active and that the evidence can be teased out of the extant textual sources. Fulvia uses marriage to restore the political standing of her house and bloodline. Virlouvet claims that Bambalion was

\footnotetext{
${ }^{42}$ Nancy Sorkin Rabinowitz and Amy Richlin, Feminist Theory and the Classics, (London: Routledge, 1993), 2-5: Rabinowitz stresses the difficulty in getting research based on women's/gender studies interests and methodology absorbed into the primary discourse because it is seen as specialist and is inherently political because it is founded in the modern political movement. The APA philological focus on language as objective with a focus on rigorous, structured, and neutral, commentary on texts almost without interpretation meant that most scholars using theory were individual faculty in small programs; the incorporation is not institutional or organizational. Additionally, the implications of the prescribed canon of texts and shunning of theory is that the study of women and non-elites whose histories can only be recovered through theoretical practice are not considered as integral to the core of the discipline.

${ }^{43}$ Ibid., 9-10;

${ }^{44}$ Catherine Virlouvet, "Fulvia: The Woman of Passion," in Roman Women, ed. Augusto Fraschetti and trans. by Linda Lappin, (Chicago: University of Chicago Press, 2001).
} 
the last male Fulvii and that the family had fallen into dispute as it seems they had been removed from the Fastii during his lifetime. The only way to restore the family was through marriage to the popular series of Plebian Tribunes Fulvia wed. Virlouvet argues that men with tribune status or potential were evidence of the family's adherence to their Gracchi family ties. It is true that Clodius was elected as tribune the year of their marriage and Virlouvet alleges that Fulvia's family connections may have been even more politically worthwhile because she may have been the step-daughter of the Consul Pinarius. ${ }^{45}$ She claims that Clodius wed her for money (as alleged by Cicero and Valerius Maximus) and her family status as a champion of the populares. ${ }^{46}$ Virlouvet does not believe that any of the coins recognized as Fulvia from Antony's mints in Lugdunum or Fulviana actually represent Fulvia because of the victory wings added to the image. This leads her to conclude that tales of the devotion Clodius and Antony gave her must have been born of true affection since Fulvia is never described as beautiful. ${ }^{47}$ Fulvia commanded both loyalty and affection because both Clodius and Antony were reprimanded for having overly passionate marriages to her. Virlouvet dismisses Cicero as a source for this information in reference to Fulvia's alleged affair with Antony. Virlouvet claims that there is no evidence that Fulvia was political or ambitious during her marriage to Clodius. Fulvia was appropriately dedicated — it was Antony who needed domineering. Curio followed the party politics outlined for him by Caesar with the help of Clodius' clodiani. ${ }^{48}$

\footnotetext{
${ }^{45}$ Virlouvet, "Fulvia," 66. Fulvia's connection to Pinarius is disputed by Weir and Hallett.

${ }^{46}$ Virlouvet, "Fulvia," 66; Cic., Phil., 3.6; Val. Max., 7.81.

${ }^{47}$ Virlouvet, "Fulvia," 68-70. The author does not draw the idea of increased affection from a lack of beauty as mentioned in Ch. 4 as a philosophical convention often used as a trope in tragedies denoting a 'higher' level of love as opposed to mere lust.

${ }^{48}$ Ibid, 69.
} 
Fulvia's marriage to Antony is described as "a sincere and reciprocal passion." 49 Virlouvet closely paraphrases Plutarch's Antony 10.3 to explain why the union was a political necessity — Caesar needed Fulvia to rein Antony in. She then follows Fulvia's political involvement through 43 using the Philippics. Virlouvet affirms Fulvia's role in helping Antony organize political alliances like that of King Deiotarus and says that the only thing proven by Cicero's claims in regards to Fulvia as a woman is that "she was not a woman who fainted at the sight of blood." ${ }^{50}$ In reference to the proscriptions, Virlouvet believes that based on the number of references in Appian and Dio to her participation that we must accept she took a prominent role. ${ }^{51}$ However, Virlouvet also believes that Fulvia's actions were entirely understandable considering that it was only a few months before the proscriptions began that Fulvia had been forced to seek refuge with Atticus and beg for her children's safety. Therefore, Fulvia's hatred of Cicero for making her husband a hostis supports the idea that Dio may have told the truth about her conduct with Cicero's severed head. ${ }^{52}$

When Antony turned eastward to secure Rome's interests, Fulvia was left in charge of his collegia and personal affairs. Virlouvet is dubious in regards to Fulvia acting as consul and manipulating Lucius Antony. In terms of participation in the conflict, she believes that Fulvia had gone to Perusia with the children to show support for the rights of her husband's veterans as they seized land. When Lucius and Octavian finally came to battle Fulvia joined Lucius in an attempt to lure Antony away from Cleopatra. Here, Virlouvet again claims that a consistency in the later sources-both

${ }^{49}$ Virlouvet, "Fulvia," 71.

${ }^{50}$ Ibid., 73. The blood Virlouvet refers to comes from the decimation at Brundisium in Cic. Phil. 3.2.

${ }^{51}$ App., B. Civ., 5.3, 5.18, 5.54-56, 5.58-59, 5.6, 5.75-76; Dio, 48.4, 48.5.5, 48.7.3-5, 49-32.3-4.

${ }^{52}$ Virlouvet, "Fulvia," 75. Fulvia may also have refused to help Hortensia (App., B. Civ. 4.5) and the other matrons being taxed because they refused to help Antony when she begged the senate not to turn against him in 43 before the battle of Mutina. 
Appian and Dio claim jealousy as Fulvia's motive — proves reality. ${ }^{53}$ Her narrative of the siege follows Dio, complete with the "girded sword." Virlouvet also feels the need to clarify that Fulvia did not, in reality die of a broken heart, but was most likely the victim of disease ${ }^{54}$ After the pact of Brundisium placed all of the fault on Fulvia, history turned away from her. Virlouvet ends Fulvia's story with the claim that she was not a "jealous virago" but an intelligent and stern person who stepped onto the battlefield out of love for Antony. To Virlouvet Fulvia's image is dominated the prejudices of the ancient writers, who, despite describing Fulvia as courageous, color her legacy with "their moral condemnation of her audacity, her jealousy, and her cruelty." This image is repeated in modern scholarship by historians who view Fulvia with the same prejudices. ${ }^{55}$

Part III: The Reconsideration of Antony and Fulvia the "Historical Character"

As discussed above, early scholars of ancient women had to define how the topic would relate to mainstream classical issues (namely political and military histories which have dominated the discourse for centuries). They had to consider conflicts between information format and audience; and, most importantly, they had to establish standards for dealing with the evidentiary shortcomings of androcentric textual and documentary sources. By the 1980s the women's history movement within classical studies fractured into studies of gender norms and sexuality and into factions of structuralists and poststructuralists. Structuralists like Phyllis Culham claim that texts cannot reveal anything about ancient women. She claims that "the study of women in ancient literature is the

\footnotetext{
${ }^{53}$ Virlouvet, "Fulvia," 77.

54 Ibid., 79.

55 Ibid., 80-1.
} 
study of men's views of women and cannot become anything else." ${ }^{56}$ Post-structuralists do accept the androcentric nature of texts but believe those texts reveal the social and cultural context in which they were created, a social and cultural context that women were a part of. Through close reading and inter-textual analysis, elements of women's lives can be recovered. Eve D'ambra describes this methodology recreating elements of women's lived reality through reading archeological sources and texts together. ${ }^{57}$ Historical revision, gaze theory, and literary theory define scholarship on Fulvia since 1990.

In 1992 Diana Delia published "Fulvia Reconsidered" in direct response to the Babcock's "The Early Career of Fulvia." 58 Pomeroy introduces the article by saying that, according to Delia, "Fulvia was primarily a wife and mother, not the androgyne and virago depicted in propaganda." 59 Balsdon had believed Fulvia to be a fully emancipated woman by arguing over the degree to which she controlled her husbands' careers. Delia says that Babcock's interpretation of Fulvia is "reminiscent of corporate wives in the 1960s." ${ }^{60}$ Fulvia has been interpreted using modern standards of behavior rather than

\footnotetext{
${ }^{56}$ Phyllis Culham, "10 Years After Pomeroy: Studies of the Image and Reality of Women in Antiquity," in Rescuing Creusa: New Methodological Approaches to Women in Antiquity: A Special Issue of 'Helios,' 13.2, Marilyn B. Skinner, ed. (1986): 9-31. Gillian Clark in Women in the Ancient World: Greece \& Rome (Oxford: Oxford University Press, 1989), 1-5, describes the response to Culham's theory as a shift from matriarchy and political action based studies towards a focus on women in the family.

${ }^{57}$ See Nancy Sorkin Rabinowitz, and Amy Richlin, eds. Feminist Theory and the Classics. (New York: Routledge, 1993); Eve D'ambra, Roman Women (NY: Cambridge University Press, 2007); Suzanne Dixon, Reading Roman Women: Sources, Genres, and Real Life. (London: Duckworth Publishing, 2007); Amy Richlin, Arguments with Silence: Writing the History of Roman Women. Ann Arbor, MI: University of Michigan, 2014.

${ }^{58}$ Diana Delia, "Fulvia Reconsidered" in Women's History as Ancient History, edited by Sarah B. Pomeroy, (Chapel Hill: University of North Carolina Press, 1991): 197-217; Charles Babcock, "The Early Career of Fulvia." The Journal of American Philology 86 (Jan., 1965): 1-32.

${ }^{59}$ Sarah B. Pomeroy, "Introduction," Women's History as Ancient History, edited by Sarah B. Pomeroy, (Chapel Hill: University of North Carolina Press, 1991): xii.

${ }^{60}$ Diana Delia, "Fulvia Reconsidered," 197.
} 
objectively. ${ }^{61}$ Delia reexplores the extent to which Fulvia controlled the careers of Clodius, Curio, and Antony. Whereas Babcock claims that Fulvia was wealthy and financed the political endeavors of Clodius and Curio, Welch suggests that her father Bambalio was alive and would have controlled that wealth or managed it through a tutor. Atticus' loan in 43 is proof that she did not control her own affairs. All men running the cursus honorum needed money so this is not really evidence. Fulvia's use of her family legacies is unproven. Hallett in Fathers \& Daughters argues that for Roman women their influence as sisters and mothers was much greater than the power they wielded as wives. $^{62}$

Babcock's entire thesis rests on Antony being controlled; he does not prove that this is the case, but he treats it as axiomatic nevertheless. Furthermore, if Clodius had been controlled surely Cicero would have said something about it either during his trials against Clodius or in the Philippics. Cicero never personally excoriates Fulvia in his letters, even those criticizing her alleged allies: Caesar, Clodius, Curio, Antony. She is not mentioned. Because of this Delia believes that Fulvia was politically unimportant. ${ }^{63}$ Delia claims that Fulvia's behavior at Clodius' funeral and at Milo's trial was not politically motivated, but representative of normal wifely obligations. Fulvia only becomes a political target after Caesar's death when the power struggle began between Antony and Octavian. Cicero was using the Philippics to emasculate Antony. Assault on family members of the victim of invective is one of Cicero's most used rhetorical

\footnotetext{
${ }^{61}$ Modern scholarly attribution of feelings and attitudes to women in the ancient world is one of the core problems caused by the androcentric nature of textual sources: the women themselves are silent and scholars, in an attempt to give them a voice, give them words and speech not their own. M. Finley, "The Silent Women of Rome, in Aspects of Antiquity: Discoveries and Controversies, (NY: Greenwood/Viking Press, 1977), 132.

${ }^{62}$ Delia, "Fulvia Reconsidered," 198; Judith Hallett, Fathers and Daughters in Roman Society: Women and the Elite Family. (Princeton: Princeton University Press, 1984), 8-11.

${ }^{63}$ Delia, "Fulvia Reconsidered, 199.
} 
techniques. As shown in Pro Caelio, Cicero will rhetorically destroy women in order to destroy their men. The second Philippic is an "unbridled attack" on Antony's family. ${ }^{64}$ Propaganda against Fulvia during the ascent of Octavian may have been an attempt by Octavian to imitate Cicero in assassinating her character as he had done Antony's. Additional charges against Fulvia grew as tensions mounted in the triumvirate. ${ }^{65}$ Delia argues that Fulvia's participation in the Perusine War was negligible. She ascribes leadership to Lucius Antony, who she feels also manipulated Fulvia into bringing her children. Delia thinks that Lucius used his brother's family to rally the soldiers at Praeneste. ${ }^{66}$ Appian's account of the conflict supports Delia's claims, saying that Lucius exploited Fulvia and the children. Delia claims that if Fulvia did act at Perusia it was in the interest of her children because "the only ineluctable legacy from Antony to the children was his name; Fulvia was obliged to champion the reputation and authority that his name conveyed in order to preserve their patrimony intact." ${ }^{\prime 67}$

In Women and Politics in Ancient Rome, Richard Bauman proclaimed that "A Fulvia did not need wear an imitation of a military uniform; she commanded an army." 68 Bauman's core theory is that Fulvia's actions and authority mark her as the first empress of Rome. Bauman's Fulvia is a gladiatrix, motivated and truly ambitious. Bauman claims

${ }^{64}$ Delia, "Fulvia Reconsidered, 200; J. Griffin, Latin Poets and Roman Life, (NC: Chapel Hill Press, 1985): 42-3.

${ }^{65}$ Delia, "Fulvia Reconsidered," 201-2. After the death of Cicero Fulvia is charged with participation in his death, in property confiscations and executions, and with denying to help the matrons of the city keep their property.

${ }^{66}$ Ibid.," 201; Dio 48.2.4 claims that Fulvia led the children in front of the soldiers and urged them to remember Philippi for the sake of their commander.

${ }^{67}$ Ibid., 204.

${ }^{68}$ Richard Bauman, Women and Politics in Ancient Rome, (NY: Routledge, 1992): 60. 
that politically "Fulvia's thinking would be unequivocally Caesarian." ${ }^{69}$ In discussing Fulvia's blood-ties to the Gracchi Bauman writes, "If Fulvia had a talent for constitutional experimentation it was genetically predictable." ${ }^{70}$ In terms of her representation in the sources, Bauman believes that Fulvia was truly a target in the Philippics because Cicero must have blamed Fulvia for his loss in Milo's trial, but "Fulvia got her revenge on 7 December 43."71 This of course refers to Dio's allegation that Fulvia abused Cicero's head. Bauman reads the sources as representative of fact and asserts that no one has "anything good to say" about Fulvia's participation in the proscriptions.

Bauman claims that Fulvia was the first empress of Rome "in all but name," and not only for her "good qualities." 72 Livia was a fine empress but was led by Augustus and had "a lifetime to emulate the military and organizational skills of Fulvia.",73

Kathryn Welch reexamined Antony's political career and Fulvia's role in it in “Antony, Fulvia, and the Ghost of Clodius in 47 BC." She presents Rome as embroiled in a bitter contest for a new political and social hierarchy based on popularity and favor, where power now rested in hands of an individual rather than with his political party's popularity. Welch states that "Fulvia contributed to the constitutional crisis which led directly to Caesar's autocracy" through her use of Clodius' legacy. ${ }^{74}$ Antony was in charge of martial rule of Rome and wanted to sway things his way. But so did Dolabella

\footnotetext{
${ }^{69}$ Bauman, Women and Politics, 77.

${ }^{70}$ Ibid, 83 .

${ }^{71}$ Ibid., 85 .

${ }^{72}$ Ibid., 85.

${ }^{73}$ Ibid., 129.

${ }^{74}$ Kathryn E. Welch, "Antony, Fulvia, and the Ghost of Clodius in 47 BC." Greece \& Rome Second Series, 42, 2, (Oct. 95): 182.
} 
and so did Fulvia; all attempted to appropriate Clodian populism. ${ }^{75}$ With a new scholarly trend towards deconstructing sources heavily based in propaganda and rhetoric, Antony was a logical choice for reinterpretation.

Welch shows Antony to have been capable but unambitious. For example, she claims that Antony's rule of Rome as Master of Horse was not unstable during 48/47 because he was incapable, it is just that Antony's ambition paled compared to Caesar's and so his policies seem lacking. Welch also claims that Antony was politically astute in regards to his social life: his drinking, partying, and womanizing helped his career. $\mathrm{He}$ did have some problems with leadership and administration but overall he was a "Misunderstood Hero" not ambitious enough to carry out policy. ${ }^{76}$ And so, according to Welch, Babcock's claim that Antony's political policies were created and controlled by Fulvia is a gross over exaggeration. She paints Fulvia as Clodius' avenger, brave enough to drag his body into public and testify at trial, in response to Babcock's claim that Fulvia had an unknowable political status. ${ }^{77}$ Welch presents Fulvia as unique, not in background or resources, but because she was the remaining symbol of the people's hero, Clodius, after his death. Clodius' clients would be managed by whomever Fulvia chose until their son was of age. ${ }^{78}$ Welch agrees with Delia's dismissal of the Fulvia portrayed by Balsdon and Babcock, but where Delia believes Fulvia was not important in any way on her own, Welch disagrees. Delia relies on Cicero in proving her point. Delia thinks that because Cicero was mostly silent on Fulvia that she must not have been important. Delia

\footnotetext{
${ }^{75}$ Welch, "Ghost," 183.

${ }^{76}$ Ibid., 184-6.

${ }^{77}$ Ibid., 187.

${ }^{78}$ Ibid., 188.
} 
completely ignores the Philippics as biased despite their uses as an interpretive source through critical analysis.

Welch argues that Fulvia's place in Cicero's crosshairs develops as his needs require. In Milo's trial Fulvia was a good wife; afterwards she was meddling, political and improper. ${ }^{79}$ Welch claims that Fulvia's role in the Perusine War was a reset of her status as the widow of Clodius, as much as the wife of Antony. During Pompey's rule all of Clodius' captains were exiled. Antony was in Gaul, and Fulvia was the remaining symbol and source of his political power through the $40 \mathrm{~s} .{ }^{80}$ Welch also claims that Antony's willingness to make Fulvia take the blame for Perusia was part of his political ambition. If he needed to he would discard those closest to him despite the personal cost. $^{81}$

The most recent studies of Fulvia focus on the way in which she is described: her motives, her dress, her actions, her relationships, not to build a greater portrait of Fulvia but to consider why she may be portrayed as soldierly or avaricious, for example. Much headway has been made through intertextual analysis and literary criticism in assessing some possible causes behind the very specific vignettes and adjectives attributed to Fulvia. For example, Judith Hallett explores how the life and career of Iullus Antonius, Fulvia's youngest son, may have been a living reminder of Fulvia's actions for Augustus. Hallett contextualizes Iullus into a larger political framework and assesses how his mother's image may have been influential in his eventual exile. Iullus Antonius was famously involved in an affair with Augustus' daughter Julia in violation of the new Lex

\footnotetext{
${ }^{79}$ Welch, "Ghost," 189.

${ }^{80}$ Ibid.

${ }^{81}$ Ibid., 185.
} 
Julia, which criminalized divorce and adultery. Using naming conventions and literary evidence Hallett sets Fulvia up as a forward-thinking politician who had planned for her sons to wield authority as the heirs to Julius Caesar. ${ }^{82}$

Following Richlin's methodology from "Approaches to Adultery at Rome" in looking at "transgressive female behavior," Hallett tries to focus on "transgressive female sexuality" in relation to Fulvia and Julia, investigating Julia and Iullus, her banishment and his suicide. Augustus overlooked Julia's alleged adulterous conduct for 15 years until her attentions turned to Iullus. Why? Augustus had just been named patria patriae and "may have been haunted by ... the matria potestas of Fulvia." Hallett argues that the evidence shows Augustus had unresolved issues towards Iullus' mother and that emotional residue led him to punish Julia. ${ }^{83}$ Though it is not possible to recreate the Roman audiences' reactions and interpretations, examining sources from all possible interpretations may reveal more information about Roman attitudes, in this case, attitudes towards "transgressive female sexual behavior." 84

Hallett reiterates the importance of physical evidence connected to Fulvia and of the 'glans' in considering glandes from Perusia. Glans is Roman slang for the tip of the penis. Many of the sling bullets have penises etched into them. Hallett reiterates that the nature of inscription on the bullets by the opposing armies treated Fulvia and Octavian as equally martial and equally penetrable ${ }^{85}$ Octavian's image at the time of the conflict is "passive and womanish," while Fulvia's is masculine and sexually deviant. ${ }^{86}$ Octavian tried to shift this image to one exuding more self-confidence and one with more virile

\footnotetext{
82 Judith Hallett, "Fulvia, Mother of Iullus Antonius: New Approaches to the Sources on Julia's Adultery at Rome," Helios 33.2 (2006), 149-160.

${ }^{83}$ Ibid., 149.

${ }^{84}$ Ibid., 150. This idea is also echoed in Richlin's "Forbidden Planet Theory," in Arguments with Silence.

${ }^{85}$ Hallett, "Fulvia, Mother of Iullus Antonius," 151.

${ }^{86}$ Ibid., 152.
} 
sexuality "because his rival Antony excelled in this particular field." 87 Octavian married Livia when she was six months pregnant and implied that he was the father. He began to flaunt affairs publicly. Word spread so well that Antony heard about them in Alexandria, as noted in Antony's De Sua Ebrietate. ${ }^{88}$ The survival of Martial's epigram 11.20 one hundred and fifty years later proves its endurance was supported by Augustus. Because Fulvia was unforgettable in the early empire and Cicero's Philippics still circulated, it was most likely very easy for later historians to build upon the descriptions of Fulvia as greedy, cruel, bloodthirsty. These are great ingredients for Dio to use in imaging Fulvia with Cicero's head and a spare hair pin. ${ }^{89}$

Late sources also demean her status as a mother; Dio essentially has Fulvia selling Clodia to Octavian and exploiting her sons to rally soldiers at Perusia. Iullus was three when Fulvia died so he was primarily raised by Octavia between 41-30. He remained in Augustus' household after Antony lost Alexandria and Augustus killed his brother Antyllus and step-brother Curio. Iullus married Marcella, Octavia's daughter, and they may have been the inspiration for the couple on the Ara Pacis. Iullus served as praetor, consul, and proconsul of Asia. He was an author and wrote a twelve-volume book on the Trojan hero Diomedes. Diomedes was Aeneas' enemy and founded the port of Brundisium. $^{90}$

Hallett assets that there is indication in Suetonius, Pliny, and Velleius that Julia and Iullus may have become too politically powerful and become a threat to Augustus. Seneca comments on the situation in saying “et iterum timenda cum Antonio mulier/

\footnotetext{
${ }^{87}$ Hallett, "Fulvia, Mother of Iullus Antonius," 153.

${ }^{88}$ Suet., Aug., 67,

${ }^{89}$ Hallett, "Fulvia, Mother of Iullus Antonius," 154.

${ }^{90}$ Ibid., 154-5. That Iullus is writing the story of Diomedes at the same time Vergil weaves Augustus into the Aeneid is interesting to say the least. Iullus' books have been lost.
} 
Again, a woman with an Antony must be feared." ${ }^{91}$ Hallett thinks that Fulvia and Antony had planned for Iullus to be a threat to Octavian, that his name was a deliberate attempt not only to evoke Caesar's but Antony's status as a descendant of the Julii through his mother Julia. Antyllus' name referenced Antony's connection to Anton, son of Hercules. Given that both boys were named during Caesar's dictatorship and Antony's term as Master of Horse and his consulship with Caesar it is fair to say that Antony and Fulvia were setting their sons up to follow their father and Caesar.

Hallett claims that because Iullus was named right after the death of Caesar when Antony and Octavian were vying for control over Caesar's legacy: 'Iullus' represents Antony's superior ancestral and political claims to the legacy of Caesar and elevates the nobility of Antony's family in comparison to Octavian's. ${ }^{92}$ She further argues that elements of the Aeneid could refer to Iullus and his supporters of Antony and the theory that Iullus may be been viewed as an heir to Augustus or a threat to his rule. Vergil's Aeneid 1.296-8 reads "A Trojan Caesar will be born to a magnificent family . . . a name derived from the great Iullus." Vergil showed Iullus as a successor. Ovid in Amores 1.657-98 has the Carthaginian queen Dido favor and choose Iullus over Aeneas. Additionally, Iullus was the only male of the Julian line besides Augustus himself. Though Seneca's statement is also thought to allude to Cleopatra or Fulvia and Antony, it may have been connecting Julia to Iullus Antony. Hallett concludes that the equation of Julia with Fulvia and Iullus with his father Marcus is what caused Augustus to punish

\footnotetext{
${ }^{91}$ Hallett, "Fulvia, Mother of Iullus Antonius," 156; Sen., Brev. Vit. 14.45

${ }^{92}$ Hallett, "Fulvia, Mother of Iullus Antonius," 157. Antony also famously took great stock in the importance of names: he modeled his personal style on Hercules and ridiculed Octavian for having no good qualities but Caesar's name.
} 
them so severely. ${ }^{93}$ Though Julia had been breaking the Lex Julia for years, Augustus chose to punish her in $7 \mathrm{CE}$ after the lover she chose, Iullus Antonius, became a threat to his political legacy, and potentially because her political aspirations evoked memories of Fulvia.

In “Perceptions of Women's Power in the Late Republic: Terentia, Fulvia, and the Generation of 63 BCE," T. Corey Brennan describes how sources treat "an important subgroup of elite women" who seem to become active in the year of Cicero's consulship and the Catalinarian conspiracy. ${ }^{94}$ Brennan for the most part gives a neutral narrative Fulvia's life events. He gives accounts of Cicero's and Clodius' roles in the Bona Dea trial. He then describes Fulvia as "stage-managing" Clodius' funeral with such success that the people of Rome burned down the Senate. ${ }^{95}$ Brennan follows the sources through Fulvia's marriage to Curio and Antony, her campaigns during Antony's exile and eastern tour. He argues that instead of reading Fulvia's story as a character assassination because she transgressed gender roles, it should be read as a study of how women who sought power in particular are described by Roman and Greek authors. Brennan describes Fulvia as "practically a case study in how elite women should not behave." Though her image is pulled from invective, Fulvia is a cautionary tale for the instruction of other women on the consequences of seeking power: you will be overcome by greed and cruelty; you will turn on other women and exploit your own children. ${ }^{96}$ She is also representative of many women who acted in military and political contexts, like Terentia, Clodia, and Servilia.

Brennan claims that attributes and actions connected to these women are constructs of the

93 "Hallett, "Fulvia, Mother of Iullus Antonius," 158-60.

${ }^{94}$ T. Corey Brennan "Perceptions of Women's Power in the Late Republic: Terentia, Fulvia, and the Generation of 63 BCE," in A Companion to Women in the Ancient World, ed. by Sharon L. James and Sheila Dillon. (Sussex, UK: Wiley-Blackwell Publishing, Inc. 2012): 354-366.

${ }^{95}$ Brennan, "Perceptions of Women's Power," 357.

${ }^{96}$ Ibid., 358, 364-5. 
"Roman male discourse on female power," and not to be read as reality. ${ }^{97}$ Therefore a study of 'active' or 'emancipated' Roman women is actually a study of the perceptions of their power and so it is not possible to trace women's participation in the development of "women's civil rights, economic power, and political influence." 98

Part IV: Fulvia and the Conventions of Morality and Literary Genre Brennan's interpretation of Fulvia and Terentia in source material reflects influence by Suzanne Dixon's Reading Roman Women: Sources, Genres, and Real Life. ${ }^{99}$ Dixon argues that scholars of women in antiquity must "acknowledge the multiplicity of 'realities' and the role of rhetorical constructions in ancient texts overwhelmingly written by, for, and about men." 100 Dixon writes that description of women and their "habits," uses women as an 'other' against which masculinity might be defined. ${ }^{101}$ She does not, however, believe that representations of masculinity and femininity prescribed by source authors represent reality or that the reality being represented can be accessed in works colored by a moral framework. Writers using morality to explain the actions of historical people transform those people into characters and constructs of discourse; in moralia neither women nor men can be accessed. Moral texts are nothing but "norms, ideals, and fantasies," fraught with symbolic language. How do these concepts effect the creation of

\footnotetext{
${ }^{97}$ Brennan, "Perceptions of Women's Power," 364.

${ }^{98}$ Ibid., 365.

${ }^{99}$ Suzanne Dixon, Reading Roman Women: Sources, Genres, and Real Life. (London: Duckworth Publishing, 2007).

${ }^{100}$ Ibid., 6-8.

${ }^{101}$ Ibid., 16. "Women appear in male-centered texts to define by opposites the masculine ideal as the norm." This theory builds on Hallett's "Women as the Same and Other in Classical Roman Elite." Helios 16 (1989): 59-78, which describes and defines the idea of gendered virtue in Roman society.
} 
Fulvia? Genre and Roman understanding of prescribed female morality create literary tropes. Archetypical characters with associated actions and motivations.

For example, the term lanificiam, so crucial to Fulvia's story, pervades texts, iconography, and funerary inscription to the extent that 'she worked with wool' did not mean that she worked with wool. It was shorthand for acknowledging that the woman being spoken of abided by gender roles: she was a good wife and mother. Lanificiam becomes a term used by men, especially in funerary contexts, by which a paterfamilias could demonstrate the superiority of his family. It doesn't really praise women as individuals; rather it is a claim demonstrating the degree to which the men in their lives were successful in controlling their behavior. This term also presents men as desirous of a woman who could be described as working with wool. Just as we cannot determine what a woman or her life was like based on the application of this phrase to her name, we cannot determine whether her husband or family would have chosen to describe her this way if lanificiam were not the standard. Women's funerary monuments are not testimonies to life but shrines to their husband's status and his willingness to promote it. ${ }^{102}$

There is also the issue of false praise meant to undermine a woman's virtues. For example, in describing the matron Sempronia as a foil for Cataline, Sallust, describes her fine qualities ironically. Her virtues are all "perversions of the virtues of her sex." 103

In the number of those ladies was Sempronia, a woman who had committed many crimes with the spirit of a man. In birth and beauty, in her husband and her children, she was extremely fortunate; she was skilled in Greek and Roman literature; she could sing, play, and dance, with greater elegance than became a woman of virtue, and possessed many other accomplishments that tend to excite the passions. But nothing was ever less valued by her than honor or chastity.

\footnotetext{
102 Dixon, Reading Roman Women, 16-7.

${ }^{103}$ Ibid., 18.
} 
Whether she was more prodigal of her money or her reputation, it would have been difficult to decide. Her desires were so ardent that she oftener made advances to the other sex than waited for solicitation. She had frequently, before this period, forfeited her word, forsworn debts, been privy to murder, and hurried into the utmost excesses by her extravagance and poverty. But her abilities were by no means despicable; she could compose verses, jest, and join in conversation either modest, tender, or licentious. In a word, she was distinguished by much refinement of wit, and much grace of expression. ${ }^{104}$

Sallust implies that Sempronia's abilities undermined her virtue: that she was born into a good family and married into one and yet her masculine desires overwhelmed her natural virtue. Whether Sempronia was made immoral by her hobbies or her hobbies reflected an immoral nature is unknown, but the impression left by this Sempronia in the minds of scholars has often caused her to be assumed to be Sempronia Tuditani, Fulvia's mother. ${ }^{105}$ Dixon argues that Sempronia is a creation, a character whose attributes are equally determined by social norms and genre.

\section{Part III: Written Women}

Genre defines the construction of a textual narrative and the characters involved, it "determines what is included, how it is treated, and what is left out." 106 This concept cannot be overstated when considering women in antiquity. Dixon warns that historians are notoriously bad at critically pulling apart their sources to look for elements controlled by genre and style, simply because historians are not trained in literary criticism. This leads to gross misinterpretation of the sources or worse-uncritical use of sources! Roman women are constructed based on literary conventions of the genre in

\footnotetext{
104 Sallust, Cat. 25. 1-4.

${ }^{105}$ Bauman, Women and Politics, 67-8, 83 initially insinuates that Sempronia is Fulvia's mother and later claims Sempronia to be Fulvia's aunt, both Sempronia's being sisters. Pomeroy, in Goddesses, Whores, Wives, and Slaves: Women in Classical Antiquity, 185 states that there is only one Sempronia and she is both the conspirator and Fulvia's mother.

${ }^{106}$ Dixon, Reading Roman Women, 19.
} 
which they appear and by the personal identity of their author. Because Roman writers were elite, middle-aged male citizens, their writing reflects the complex interaction between their personal "ideologies, self-image, public image, and lived experience." 107 Women are written about for complex purposes. They are not written about for their own sake. Women generally are not mentioned unless there is a specific reason for an author to do so. Dixon uses for example the coincidence of accusations of overt sexuality and political activism. It is a trope designed to represent moral decline, while moral decline is a trope used to explain political instability. ${ }^{108}$ Women like Sempronia, Clodia, and Fulvia are convenient examples to use in support of Augustan morality laws. Clodia Metelli, Fulvia's sister-in-law, is another Roman woman of the later Republic whose historical reality is camouflaged behind the historical character built for her by Cicero. Marilyn B. Skinner offers a history of Clodia as told by the sources in Clodia Metelli: The Tribunes' Sister. Skinner asserts that Clodia's reputation was put on trial and damaged by Cicero because of Clodia's support of Clodius' political campaigns in $58 \mathrm{BCE}$ using the Metelli name and the auctoritas it carried. ${ }^{109}$ As a result all information about the true personality of Clodia is tainted by Cicero in Pro Caelio and by Catullus as the woman behind his character Lesbia. The resulting historical character or historicized version of Clodia is a composite image that "cannot be studied in isolation from her ancestral origins, her immediate and natal families, marital status, the shared expectations for females of her class, and the wider operations of government and Roman society." ${ }^{110}$ We can recreate aspects of the historical context in which she

\footnotetext{
${ }^{107}$ Dixon, Reading Roman Women, 22.

${ }^{108}$ Ibid., 23-5, 74-75.

${ }^{109}$ Marilyn B. Skinner Clodia Metelli: The Tribunes' Sister (Oxford University Press, 2011), 3.

${ }^{110}$ Ibid., 4; Dixon, Reading Roman Women, 134.
} 
lived and make suppositions about expectations placed upon her based on her patrician and female statuses, but Clodia, the woman put on trial by Cicero, is a stock characterthe meretrix (whore). Likewise, Clodia, the woman called Lesbia by Catullus, is a stock character in elegy, the immovable object of the poet's love. Both Skinner and Dixon describe the alternate ways in which Clodia is portrayed genre by genre.

In Cicero's personal letters to Atticus, Clodia is an astute patron of her brother's political interests and, as such, a political adversary. In Pro Caelio Cicero employs the rhetorical device of morality and character destruction to undermine Clodia's testimony. ${ }^{111}$ Cicero accused Clodia of paying Caelio to perform cunnilingus on her, thus putting her in the active male role. ${ }^{112}$ Cicero alleged that her affairs were only with elite men who needed money. This means that she was also treating elite men as though they were female whores. Additionally, a woman who actively seeks and enjoys sex is "by definition abnormal and masculine." Active sexual enjoyment by women subverts societal roles; it turns a matron into an adulteress or a whore. ${ }^{113}$ Why would Cicero make these allegations about Clodia? To undermine her brother Clodius, his enemy. Based on these pretenses Cicero is able to claim that Clodia wasn't stopped because Clodius was not a 'real' man. ${ }^{114}$ Clodia is punished for being politically active through the rhetorical accusation of sexual transgression in the same way Fulvia was for her

\footnotetext{
${ }^{111}$ Dixon, Reading Roman Women, 24.

112 Holt N. Parker "The Tetragenic Grid" in Sexuality in Greek and Roman Culture. ed. Marilyn B. Skinner, (Blackwell Publishing, 2005):47-65. According to Parker, page 47: Roman "sexual categories are based on divisions of age, social status, ritual category, or power relations and often cut across or simply ignore the biological classes of male and female." 48: Gender is active and passive not male and female because "the normative action is the penetration of a bodily orifice by a penis, the active is male, the passive is female." Romans viewed a man engaging in cunnilingus as equating to a man being penetrated vaginally. Passive man is a cinaedus and an active woman = virago or tribas. A virago is a woman active in male affairs not necessarily sexual, while a tribas is a woman who penetrates other women with her clitoris. ${ }^{113}$ Ibid., 58.

${ }^{114}$ Ibid., 70-71; Dixon, Reading Roman Women, 133, 140-5.
} 
work for Antony and Julia was for her connection to Iullus. Clodia could have been remembered for her support of her brother as Julia, Antony's mother is, if not for Cicero. Dixon argues that Fulvia, for her political support of Antony and the populares cause, should have been revered in texts like Cornelia, mother of the Gracchi. ${ }^{115}$ Again, if not for Cicero. The actions of these women could have been treated as positive and as fulfilling obligations to the men in their lives but that would not suit Cicero's grudge against Clodius, nor his desire to convince Rome that Antony was unfit leader, nor Octavian's need to prove that he was as competent and virile as Antony.

Stock stereotypes and literary conventions (this time from Greek myth and tragedy) also influenced Plutarch's conception of women in his works, particularly in The Life of Antony. Female characters have more of a role in Antony than other Lives. This is because Plutarch considers them vital to supporting his narrative of immoderation. Each woman in the narrative controls Antony in some way. His mother shapes his understanding of marriage. Fulvia directs him politically and urges him to further violence and warfare. Cleopatra convinces him to luxuriate in Alexandria and scorn his Roman wives. Octavia convinces Antony to negotiate against his own conscience. Antony has no boundary between public and private life. His closest friends and lovers are political allies. He has no control over his desire for excess, particularly money and women from beginning of his story. Beneker claims that “Plutarch has used Antony's various wives to represent the psychological struggle between reason and Eros in his

\footnotetext{
${ }^{115}$ Suzanne Dixon, "The Enduring Theme: Domineering Dowagers and Scheming Concubines," in Stereotypes of Women in Power: Historical Perspectives and Revisionist Views, ed. B. Garlick, S. Dixon, P. Allen, (NY. Greenwood Publishing, 1992; Suzanne Dixon, "Unsexing Fulvia: A Dangerously Undomesticated Roman Wife," dangerouswomenproject.org, July 19, 2016, http://dangerouswomenproject.org/2016/07/19/unsexing-fulvia/
} 
soul." 116 There are eighty-seven chapters in the Life of Antony. He has no wife or female consort for ten chapters. In chapters one through nine Antony is a young man and involved with Clodius and Curio. He has no wife mentioned. In chapter eighty-seven Antony's story comes to an end. No wife is mentioned. Fulvia is the central female character in Antony's life for twenty chapters. Cleopatra and Octavia share the spotlight for the next twenty-six chapters, and Cleopatra shines alone in the remaining twentynine. ${ }^{117}$ Each woman controls Antony in a different way and is described and presented as a different literary archetype. The Life of Antony is also aligned with stage elements: costume described in detail to suit narrative plot, a great struggle for power, full of stock characters. Elements of elegy, pantomime, and Greek epic are found in the historical character of Fulvia as created by Plutarch, Appian, Dio, Velleius, and Valerius Maximus. ${ }^{118}$ Play and pantomimes based on historical characters were popular during the period Plutarch wrote Lives. An episode in the Life of Demetrius concerning a romance between his daughter Stratonice and a rival Antigonus was actually a popular pantomime during the time in which Plutarch was writing, and was featured in Appian and Lucan. ${ }^{119}$

In Plutarch's Lives and Moralia, Roman women are used as exempla of specific themes: strength of morals when confronted with obscenity, concealment, physical exploitation in opposition to manly courage (andreia or virtus) or as characters who have

\footnotetext{
116 Jeffery Beneker, The Passionate Statesman: Eros and Politics in Plutarch's Lives, (Oxford: Oxford Press, 2012), 175.

${ }^{117}$ Plut., Vit. Ant., Antony is married to Fulvia in chapters 10-30; Cleopatra and Octavia in 31-57; Cleopatra alone in 58-86.

${ }^{118}$ Suzanne Dixon, Reading Roman Women, 36-42; Judith Hallett, "Fulvia: The Representation of an Elite Roman Woman Warrior." in Women \&War in Antiquity, ed. Jacqueline Fabre-Serris, Alison Keith. (Baltimore: Johns Hopkins Press, 2015): 260-5.

Amy Richlin, "Invective Against Women in Satire," in Arguments with Silence: Writing the History of Roman Women, (Ann Arbor, MI: University of Michigan, 2014): 62-80; Wyke, The Roman Mistress, 3240 .

119 Simon Swain, “Novel and Pantomime in Plutarch’s Antony,” Hermes 120 (1992): 76-7.
} 
failed to meet these expectations because of lack of morality. Women are never the primary subject. They are united by common elements. All women with speaking roles are elite and only speak during times of public crisis. Plutarch uses speech to depict the character of the speaker. This is the rhetorical practice of ethopoeia: the impersonation or creation of a character by imagining or acting out their words used to recreate ethos and pathos in the subject and inspire them in the audience. All women who speak in his texts are positive figures. ${ }^{120}$ Four of the eight women with speeches in Plutarch's Lives are modeled on Homer's Andromache, specifically Iliad 6407-39, (when Andromache addresses Hector). ${ }^{121}$ This speech is used as the framework for speeches by Portia to Brutus, Cornelia to Pompey, Octavia to Antony. The Roman women's words differ. They are more selfless and confident in their words and display "moral courage and civic responsibility." 122 Plutarch employs antithesis (A not B) as a rhetorical framework used by his characters: Portia claims she has the desire and ability to be Brutus' partner in success and failure because she is his wife not a concubine. This idea is both a statement on the inferred strength and goodness of Brutus and a jab at the East as a place of passions. Portia shows intelligence, knowledge of rhetoric, and an understanding of Brutus' nature, but she also claims not to be the source of these characteristics; she is Cato's daughter and wife of Brutus. Through these men she is able to exercise intelligence, education, and reason. Women are allowed to be politically active but it

\footnotetext{
${ }^{120}$ Bradley Buszard, "The Speech of Greek and Roman Women in Plutarch's Lives," Classical Philology 105, 1 (Jan., 2010): 83-5.

${ }^{121}$ Homer, Iliad, 6407-39: "Then Hector smiled, as he glanced at his boy in silence, but Andromache came close to his side weeping, and clasped his hand and spoke to him, saying: "Ah, my husband, this prowess of yours will be your doom, for you have neither any pity for your infant child nor for hapless me that soon shall be your widow; for soon will the Achaeans all set upon and kill you. But for me it were better to go down to the grave if I lose you, for nevermore shall any comfort be mine, when you have met your fate, but only woes." Translation mine.

122 Buszard, "Speech of Greek and Roman Women," 88.
} 
must be self-sacrificing and done in the name of a husband or close male relation to maintain its moral patina. Women could appropriately negotiate in public and private if it was not for their own benefit. ${ }^{123}$

Octavia is able to speak to the Triumvirs to make suggestions for terms on treaties, and speak in Athens while maintaining her status as a dutiful matron because her public role is not hers; it is for the sake of Rome and her family that she speaks. ${ }^{124}$ She argues for the stability of her family through peace between her husband and her brother. It pains her to make public pleas, but she was unable to remedy the situation in private. This is a last resort and typically against her nature. Octavia is used as a metaphor for hope as the remaining connections between Octavian and Antony. This is treated in comparison to Cleopatra, who rules independently and operates for her own personal gain. ${ }^{125}$ Buszard claims that "Antony's passivity is the defining attribute of his character, so the conflict between these women determines in large part the outcome of his career." ${ }^{126}$ The personal character of the written women, Fulvia and Cleopatra, to whom Antony is submissive and surrenders, allows the character of Antony to be defined and explains his downfall. The character of Fulvia is closely drawn from Roman elegy tropes. She is a character drawn from the virago, the mistress, and the old woman.

Simon Swain explored the impact that pantomime and novel tropes had on Plutarch's Life of Antony. The influence of genres outside of moralia and biography on Antony begin in its complement, The Life of Demetrius, in which anecdotes about

\footnotetext{
${ }^{123}$ Buszard, "Speech of Greek and Roman Women," 92-3.

124 This follows Hortensia in App., B. Civ., 4.5. 32 and V. Max., 8.3.3.

${ }^{125}$ Buszard, "Speech of Greek and Roman Women," 97; Plut., Vit. Ant., 35.3-5,31.2-4,53.2-4,54.1-4,87.1.

${ }^{126}$ Buszard, "Speech of Greek and Roman Women," 98.
} 
Demetrius' daughter Stratonice were drawn from pantomimes popular at the time. ${ }^{127}$ According to Swain, Plutarch borrowed elements of the love motif from stage romances, popular novels, and pantomime to pad Antony's love story as a core aspect of his downfall. One indication of the influence of novel and pantomime romance on the story of Antony is the focus on his education, not only his education in oratory but his education in love. Plutarch's use of the term paideia and references to instructional fees due Fulvia are drawn from the character of Palaestra, who is a female wrestling teacher who 'trains' the hero of the story Lucius in the ways of love (and erotic wrestling.) ${ }^{128}$ Plutarch claims that the pantomime school that Volumnia Cytheris attended was called palaestra. ${ }^{129}$

Fulvia's control of Antony employs thematic language from the idea of the institutio amoris, the school of love. Antony was described as easily led so Plutarch had little difficulty in translating his love affairs into teacher-pupil arrangements. Swain also notes that Plutarch as an author and philosopher dedicated to imparting morality was of course interested the idea of paideia. ${ }^{130}$ Visualized emotional scenes, especially those centered around the idea of separation and reunion of lovers, were common and popular in theatrical production. This reflects Plutarch's description of Antony sneaking away from this post in costume to pay a surprise visit to Fulvia. ${ }^{131}$ Swain notes that Fulvia is also described in terms generally applied to a character from Latin elegy, the domina.

\footnotetext{
127 Simon Swain, "Novel and Pantomime in Plutarch's Antony," Hermes 120 (1992), 77-8.

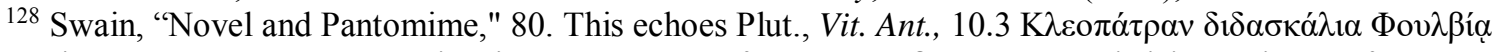

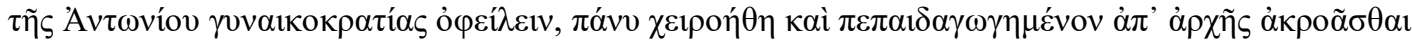

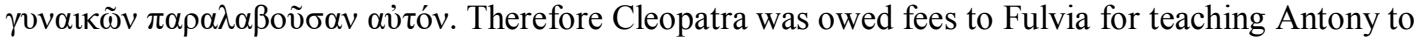
endure a woman's sway, since she took him over quite tamed, and schooled at the outset to obey women.

${ }^{129}$ Swain, "Novel and Pantomime," 80; Plut. Vit. Ant. 9.7 Swain notes that Palaestra is also usually the name of stock characters who are prostitutes.

${ }^{130}$ Swain, "Novel and Pantomime," 80.

${ }^{131}$ Plut., Vit. Ant., 10.4-5.
} 
Maria Wyke echoes this sentiment and adds that Fulvia's character also bears elements of the elegiac mistress, while Antony is depicted as the pining lover. ${ }^{132}$

In Augustan elegy masculinity and femininity are used as "sites of negotiation and contestation" with femininity serving as a "mechanism for contestation of social and political structures." ${ }^{\prime 33}$ The use of femininity as an exploratory construct turns written women into concepts rather than identities. Elegy has been used uncritically to fill in gaps in women's lives by Balsdon and Pomeroy, who used Roman poetry to create generations of sexually liberated Roman women in the later Republic. ${ }^{134}$ Wyke argues that elegiac women like Propertius' Cynthia are highly stylized written figures created using specific literary conventions.

The male elegiac character is a pining love slave whose woman is his domina. This is the female equivalent of the dominus who wielded sexual authority over all slaves belonging to the family. ${ }^{135}$ The elegiac domina "contrasts with that traditionally prescribed for Roman matronae, namely, keeping house and working wool."136 This perfectly describes Fulvia "who took no thought for spinning or housekeeping."137 Additionally the male poet character controlled by the domina is driven by her to deny his traditional male behavior: "he slights all the responsibilities of being a citizen and

\footnotetext{
${ }^{132}$ Swain, 81; Maria Wyke, "The Roman Mistress: Ancient and Modern Representations, (Oxford University Press, 2007), 170. Wyke writes that it is also tempting to connect Fulvia (and Cleopatra) to the dux character from the elegiac theme milita amoris (love is a battle). Wyke says the dux commands her poet/lover to "man-up" and overthrow his enemies in order to win her love.

${ }^{133}$ Wyke, Roman Mistress, 4.

${ }^{134}$ Ibid., 12-3; During the 1970s Propertius was treated as a pro-feminist for his character Cynthia.

135 Ibid., 30-2.

${ }^{136}$ Ibid., 34.

${ }^{137}$ Plut., Vit. Ant., 10.3.
} 
soldier.."138 Antony allegedly shirked his duties to Caesar, left his post, and secreted himself home to deliver a love letter to Fulvia. ${ }^{139}$ This episode was drawn originally from Philippics 2.31.77-8:

But mark now the trifling character of the fellow. When about the tenth hour of the day he had arrived at Red Rocks, he skulked into a little petty wine-shop, and, hidden there, kept on drinking till evening. And from thence getting into a gig and being driven rapidly to the city, he came to his own house with his head veiled. "Who are you?" says the porter. "An express from Marcus." He is at once taken to the woman for whose sake he had come; and he delivered the letter to her. And when she had read it with tears (for it was written in a very amorous style, but the main subject of the letter was that he would have nothing to do with that actress for the future; that he had discarded all his love for her, and transferred it to his correspondent), when she, I say, wept plentifully, this soft-hearted man could bear it no longer; he uncovered his head and threw himself on her neck. Oh, the worthless man (for what else can I call him? there is no more suitable expression for me to use)! was it for this that you disturbed the city by nocturnal alarms, and Italy with fears of many days' duration, in order that you might show yourself unexpectedly, and that a woman might see you before she hoped to do so? And he had at home a pretense of love... ${ }^{140}$

Given that Cicero's second Philippic was meant to circulate through the homes of common Romans, ${ }^{141}$ referencing and eliciting images of novel and elegiac characters that people would generally be familiar with discredits Antony and Fulvia. It undermines Antony's role as a tribune to be imagined as a love-sick poet, weeping over the love be professes to the woman who controls him. It also portrays Antony as a man who would abandon his post and disobey Caesar's commands for love (and sex).

Another aspect of Fulvia's written character is her greed and avarice. These attributes define the elegiac courtesan popular under Augustus. Augustan elegy censures luxuria and avaritia because they are viewed as factors contributing to the chaos of the late Republic. Luxury is a trope representing moral decline. Fulvia is shown to be driven

\footnotetext{
${ }^{138}$ Wyke, Roman Mistress, 35.

139 Plut., Vit. Ant., 10.4-5.

${ }^{140}$ Cic., Phil., 2.31.

${ }^{141}$ Nancy Myers, "Cicero's (S)Trumpet: Roman Women and the Second Philippic." Rhetoric Review, 22 (4, 2003): 337-352.
} 
by greed and avarice by Cicero and Appian. ${ }^{142}$ Propertius 37-42 involves Antony and Octavian demonstrating the cost of infamis amor (the shameful love) of being enslaved to luxury. The denunciation of luxury and jealousy is rhetoric of "female indulgence as an index of social corruption." Social corruption is represented by women "exercising sexual, political, and economic authority. ${ }^{143}$

The most recent study of Fulvia is Judith Hallett's "Fulvia: Representation of an Elite Woman Warrior." ${ }^{\text {144 }}$ Hallett too explores how historians have been influenced by the conventions of poetry, fiction, elegy, and epigrammatics when writing Roman women. Fulvia's personality, as described by Martial 11.20 as well as some elements of Philippics cast Fulvia as the archetypical "wicked matron." This made Fulvia an even easier character to compare with Octavia. ${ }^{145}$ Additionally, aligning Fulvia with elegiac and literary characters discredits any political or military authority she possessed. Martial's epigram demeans and masculinizes Fulvia by not only equating sex with Fulvia to sex with Antony's officer Manius, it characterizes her as a wicked matron and a meretrix. Fulvia's demand that Octavian choose sex or war is an elegiac trope as is revenge sex against an unfaithful spouse. ${ }^{146}$ Cicero also connects Fulvia to elegy through casting Antony and Fulvia as elegiac lovers whose marriage is shadowed by Antony's mistress Cytheris. Cicero regularly equates the two women in Philippics. Cytheris was the subject of popular elegies by Cornelius Gallus after Antony married Fulvia. Cicero

\footnotetext{
${ }^{142}$ Cic., Phil., 2.95, 2.113,3.16,5.11,5.22,6.4; App., B. Civ., 4.4.29; Dio, 47.8.2; V. Max., 9.5.4.

${ }^{143}$ Lowel Bowditch, "Propertius and the Gendered Rhetoric of Luxury and Empire: A Reading of 2.16," Comparative Literature Studies 43.3 (2006): 316. Antony is depicted by Propertius as a loser who lost to luxury, desire, Hellenism, and barbarian ways.

${ }^{144}$ Judith Hallett, "Fulvia: The Representation of an Elite Roman Woman Warrior," in Women \&War in Antiquity, ed. Jacqueline Fabre-Serris and Alison Keith., (Baltimore: Johns Hopkins Press, 2015: 247-265). ${ }^{145}$ Ibid., 248; Cic., Phil., 5.4.11, 2.36.

${ }^{146}$ Hallett, "Fulvia," 250. Hallett says that Fulvia's image in Martial is based on Catullus 68 in which Hera is filled with "blazing anger" over Zeus' escapades.
} 
elevated Cytheris to wifely status in his invective to drag down Antony and Fulvia, mocking their marriage. ${ }^{147}$ Cicero, first of all, uses Cytheris' name but not Fulvia's; she is only "that woman" or "that wife of yours." He also described Antony's break up with Cytheris as a divorce. ${ }^{148}$ According to Cicero Antony's life could be summed up by his 'divorce' from Cytheris, saying “In this man's entire life nothing is more honorable that that he divorced a female mime. ${ }^{149}$ Fulvia's image as a military commander demanding sex may also have been influenced by Petronius, who wrote parodies of Propertius' elegies and his character Cynthia, the imperious lover. Cynthia was militarily aggressive and fought in the wars of love, commanding her lover's submission. Hallett states that Appian and Dio "seem to have taken these earlier sources seriously, uncritically accepting their assertions." ${ }^{150}$ Images of Fulvia may also have been continued through the works of Iullus who, in addition to writing his epic poem on Diomedes, was also an elegist in the circle of Ovid and Horace. ${ }^{151}$

\section{Conclusion:}

The chapter has shown that the written image of Fulvia contains as many literary and rhetorical facets as there are writers who have claimed to know her story, her personality, and her intent over the millennia since her death. The historical character of Fulvia may have been influenced by the female characters of elegy, by tragic and mythological characters like Hera and Clytemnestra, by the concept of female transgression into political and military command as a sign of the moral decay of the

\footnotetext{
${ }^{147}$ Hallett, "Fulvia," 257.

148 Cic., Phil., 2.24.

149 Hallett, "Fulvia," 257-8; Cic., Phil., 2.28.69.

${ }^{150}$ Hallett, "Fulvia," 262.

151 Ibid.
} 
Republic. Chapter 4 continued exploring the construction of Fulvia as a historical character in the rhetoric of Roman writers, philosophy, and the propaganda of the Augustan regime in its attempts to destroy the legacy of Mark Antony as all of these elements add even more layers of distortion on the true character of Fulvia. 


\section{CHAPTER 4}

\section{HOW TO DESTROY A ROMAN HERO (OR, THE DESTRUCTION OF HERCULES)}

The core ideas connected to Fulvia in terms of her actions and motives all bear the influence of Augustan propaganda, rhetoric, Roman moral and gender norms, and the shadow of Antony's damnatio memoriae. This chapter discusses why Fulvia is thought to have been domineering, politically active, greedy, cruel, vengeful, jealous, willing to raise and control an army, and marked as a virago. In order to earn and then secure and legitimize his place as Princeps, it was necessary for Octavian/Augustus, to destroy the popularity and popular legacy of his rival, Antony. The impact of Augustus' image campaign echoed well into the Imperial period and directly influenced all of the biographic and historiographic representations of Fulvia. Her actions, her personality, her desires, her legacy in text are evidence designed to undermine Antony's capacity for leadership and his status as a vir of the Roman Republic. The historical characters of Antony and Fulvia exist at the intersection of propaganda, rhetoric, textual genre, and contextual cultural morality of gender. The Fulvia filtered through the layers of political invective and slander embroidered to fit rhetorical frameworks and theatrical archetypes is not representative of the historical woman, Fulvia Flacca Bambula.

Part I: Submission:

Mark Antony's true image is the most damaged of all historical male Romans by 
"manipulation of gender stereotypes." 1 Plutarch is partly responsible but he is one writer among many who contributed to the destruction of Antony as a man, as a husband, as a Roman, and as an imperator. Plutarch did not create the literary Antony- the emasculated Antony-himself, but he strung together all of the existing propagandistic elements into one narrative, blending, "truth and innuendo." His cohesive narrative gives credulity to Cicero's slander by weaving it into a factual narrative framework. Augustan propaganda begins in earnest after the death of Caesar with Cicero's Philippics in 44 BCE. During the next two centuries all modes of literary, historical, and rhetorical devices are used by annalists, moralists, and historians to explain the events surrounding the fall of the republic, to explain how Mark Antony was a man lost in an age when "Antony's archenemy had become not just emperor, but god." One way in which the character of Antony is analyzed was through his status as a vir, an elite Roman man, a complex and changeable status. Corbeill writes of Roman masculinity and femininity that, "No normal man might actually become a woman, but each man trembled forever on the brink of becoming 'womanish.",33 After the battle of Philippi Antony was Rome's military victor. He was courageous and well liked. Octavian's reputation, however, was pathetic. Octavian was the antithesis of Antony: Antony was robust, heroic, lenient towards his enemies, joyous; Octavian was sickly, cowardly, cruel, unhappy. Where Antony enjoyed life, Octavian shunned pleasures. He was even accused of "unmanly conduct befitting a supreme military commander" at Philippi by his friend Marcus

\footnotetext{
${ }^{1}$ Brigetta Ford Russell, "The Emasculation of Antony; the Construction of Gender in Plutarch's Life of Antony." Helios 25.2 (1999): 121.

${ }^{2}$ Ibid.

${ }^{3}$ Antony, Corbeill, Controlling Laughter: Political Humor in the Late Roman Republic. (Princeton, NJ: Princeton University Press, 1996), 145. Note follows P. Brown citing Galen's De Semine.
} 
Agrippa. Octavian was harassed by constant accusations of passive sexuality with both Julius Caesar and Aulus Hirtius. He was known to be effeminate in dress and grooming. For example, Suetonius 82.1 claims that Octavian wore platform sandals and singed the hair on this legs with hot nut shells to make it softer. By 27 BCE Octavian was actively working to enhance and repair his public image. Agrippa's role was drawn back so that Octavian could claim glory. ${ }^{4}$ In order to revise his image, Octavian sought not only to repair his public persona but to destroy the reputation and legacy of Antony. There are many ways a Roman man could undermine the status of another: attack his morality, his family, his masculinity, his speech, his patriotism, his piety, his valor. This section explores how rhetoric and propaganda relating to the Roman view of gender and sexuality were used to 'emasculate' Antony and 'masculinize' Fulvia.

The use of rhetoric allowed Romans to explore the relationship between the individual and the state and served to define men and women through their appearance, words, and actions. For Romans rhetoric "creates social norms by exposing the violations of those norms." Through exempla, or didactic examples, "elite culture... reinforced its own concept of "Romanness" through the use of public invective." 6 Physical appearance was equal to moral character, and faults in mental or physical capacity were physical manifestations of immorality. Romans were defined by comparison to non-Romans, men by comparison to women. Effeminacy was both social and natural failure and "the

\footnotetext{
${ }^{4}$ Judith Hallett, "Perusinae Glandes and the Changing Image of Augustus." AJAH 2 (1977): 157-9; Kenneth Scott, "The Political Propaganda of 44-30 BC," Memoirs of the American Academy in Rome 11 (1933): 7. Between 44-30 BCE all types of propaganda were employed by both Antonian and Augustan forces: "charges, counter-charges, manifestos, pamphlets, lampoons."

${ }^{5}$ Corbeill, Controlling Laughter, 4-6

${ }^{6}$ Ibid., 15.
} 
theoretical possibility that a man could lose his gender has opened up a legitimate space for invective." ${ }^{, 7}$ Romans of the republic believed in the separation of public and private spheres and in inherent male and female virtues. The virtues aligned with the responsibilities assigned to men and women in running the state and the home respectively. The home and family were the building blocks of Roman society and each Roman was responsible for maintaining expected duties and behavioral norms depending on the individual's sex and class status. Individual morality was the responsibility of the paterfamilias, as was the morality and behavior of his family members. It was held that if a man cannot control himself, his wife and his family (and to some extent his associates) his manhood was in question.

Virtues defined morality and reflected gender status. Male virtues include virtus (courage/manliness), fortitude, self-control, firmitas animi (soundness of mind). Female virtues are chastity, modesty, obedience, wool work/ "domestic virtues," (pudicitia, modestia, obequium, lanificiam). ${ }^{8}$ A person's action displayed his or her character and defined the individual in contrast to non-Romans, and separated men from women and the servile class. A man who was not in control was controlled. Furthermore, those unable to exercise self-control were unfit to control or command others. In the hierarchy of virtues, male virtues are superior to female virtues. Masculinity is also defined by lack

\footnotetext{
${ }^{7}$ Corbeill, Controlling Laughter, 150. On physical appearance, Cic., Phil., 3.16 gives an example: "Nothing is more contemptible than that man (M. Fulvius) who had received his name (cognomen) in abuse for the clinging nature of his tongue and the dullness of his soul." M. Fulvius Flaccus' cognomen was Bambulio. He was Fulvia's father. Bambalio comes from balbutio/balbutire: stammer, stutter; lisp, babble. ${ }^{8}$ Emily Hemelrijk, "Masculinity and Femininity in the 'Laudatio Turiae,", The Classical Quarterly 2, 54.1 (May, 2004): 185-8; Suzanne Dixon, Reading Roman Women: Sources, Genres, and Real Life. (London: Duckworth Publishing, 2007): 56-8; Sarah B. Pomeroy, Goddesses, Whores, Wives, and Slaves: Women in Classical Antiquity, (New York: Schocken Books, 1975): 149-151.
} 
of inferior virtues associated with female stereotypes of weak will infirmitas animi, impotentia muliebris. The concept of male virtue was also a rhetorical framework that could be used in analogy to prove superiority. ${ }^{9}$ Because Antony regularly displayed virtus, it was necessary to focus on other virtues he lacked, like self-control, and to apply feminine virtues to him in order to undermine his political and military status. Two virtues repeatedly applied to Antony are obsequium and luxuria. Obsequium for a woman meant obedience to her husband. Cicero, Plutarch, and Appian use the concept to demonstrate Antony's obedience and submission to Curio, Fulvia, and Cleopatra.

Submission to another man and to women is damaging on its own as a charge, but this idea implied other types of immorality including homosexual behavior and immoderation. Hemelrijk writes that for men there was no greater affront than being feminized because it had such a wide range of connotation: "the lack of force and selfcontrol generally attributed to women: effeminate men were accused of weakness, cowardice, and a variety of other vices, such as sexual licentiousness and luxuriousness." ${ }^{10}$ Eleanor Winsor Leach writes that "evidence for effeminate conduct as a species of political defamation" can be found as early as the $4^{\text {th }}$ century BCE. Gender for Romans is not in alignment with biological sex but the semiotics of domination and subordination combined with importance of maintaining image. This importance multiplies as one wields power and prestige through accomplishment and lineage. Antony and Octavian were negotiating a world in which "defective masculinity" is a "threat to

\footnotetext{
${ }^{9}$ Hemelrijk., "Masculinity and Femininity," n. 21; Sen., Const. 2.1.1.

${ }^{10}$ Hemelrijk, "Masculinity and Femininity," 189.
} 
the social order." Social order is the foundation of the republic. It is also a world in which engaging in the manner, dress, or actions of a subordinate makes you subordinate. ${ }^{11}$

Cicero alleges in Phil. 2.44-5 that Antony engaged in bodily submission to Curio. This allegation was meant to strip Antony of his status as a vir and emphasize his lack of morality. Roman sexuality dictated that "intercourse was constituted solely as bodily penetration of an inferior, a scenario that automatically reduced the penetrated individualwoman, boy, or even adult male to a "feminized" state." 12 And so, accusing Antony of homosexual acts in which he was the penetrated party feminized him. Being recognized as a vir required social status and peer respect: being male did not make you a man. Men are impenetrable and are designated by class, bodily freedom being the difference between vir and homines, between man and people. Because gender was defined not with physiology but by penetrative status "sexual penetration is used to mark a gender boundary." 13 The assimilation of homosexual to heterosexual sex acts by assigning the individual with penetrated feminine status meant that partners always assumed active/passive role, male/female. Cicero accusation made Antony a muliebria pati, a male penetrated by another male, a man “'having a woman's experience'.” Antony is also accused of submissive behavior, of having his actions controlled and dictated by women. $^{14}$

Although Roman women wielded influence through moral auctoritas, this authority did not extend to the public sphere or the politics of the forum. Women could

\footnotetext{
${ }^{11}$ Eleanor Winsor Leach, "Gendering Clodius," The Classical World 94, 4 (Summer, 2001): 339-40.

12 Jonathon Waters, "Invading the Roman Body: Manliness and Impenetrability in Roman Thought" in Roman Sexualities edited by Judith P. Hallett and Marilyn B. Skinner. (Princeton: Princeton University Press, 1997): 3 .

13 Ibid., 30.

${ }^{14}$ Waters, "Invading the Roman Body," 31-32.
} 
work within the boundaries of the home and social network but not be seen or thought to influence men publicly. Asconius dubbed this concept materna auctoritas and it operated through persuading others of the 'rightness' of an action or argument within the traditional patriarchal structure of the family. Women and men who worked outside of the traditional power hierarchy were violating morality. All historical recounting of Roman women exercising appropriate authority which had greater political ramifications became subject to polemical rewriting because their actions damaged men's authority. Their actions are treated with hostility even in historical sources because their accounts most likely appeared in the "more colorful mediums, or in contemporary political pamphleteering, or in apologiae that, at their most crude, were not dissimilar to forensic oratory and employed similar techniques." 15

"Powerful" women who undermined male authority were "defamed" through character assassination. Character assassination a is standard rhetorical device for undermining an opponent's words, deeds, and value. During Cicero's age, the most popular technique for undermining a woman was to claim she was motivated or overcome by cupiditas. Cupiditas was interpreted as lust, greed, avarice: all "unhealthy passions" that serve to condemn a person's character. A man submitting to a woman is also victim of a woman overcome by cupiditas. There are two main ways a man could be linked to a woman through this rhetorical device: through claiming that the woman is the source of dubious advice that the man follows or that he is entirely, in action, word, and deed, her agent or slave. According to Cicero, “"The man of respect' was guided by nothing but his own virtue. He did nothing by compulsion or against his better

\footnotetext{
${ }^{15}$ Tom Hillard, “Republican Women, Politics, and the Evidence.” Helios 16 (1989): 165-6.
} 
judgement." ${ }^{16}$ Alleging that a man was controlled by a woman was invective on several levels: it implied passivity and servitude. Hillard asserts that the key feature of this type of rhetoric "was the interpretation of a woman's influence as involving the subordination of a man." ${ }^{17}$ This charge could be elevated if the man held office. Then invective became coercitio, because a man in office subservient to a woman made their relationship of political concern. If she controls him and he has authority over us, the public, she actually controls us. Fulvia controlling Antony, commanding the commander, made all of Rome Fulvia's.

"Feminine caprice" was another device used to explain irrational female and male action. Hillard argues that this type of rhetoric was designed to discourage women from being seen to openly exercise power or clearly assist or influence men, especially those in power, unless for appropriate reasons. Women can be powerful and can ally with men but it must not be for the woman's own needs or desires. The man in any relationship must be in control, especially if he held political office. A man could be impugned for being influenced by a woman, with accusations that her 'whispers' led to his action. Women were accused of turning weak-spirited men to greed and cruelty, inspiring "cruel excesses." 18 There was even a standard formula: Man A did nothing without Woman B's approval. Cicero proclaims in Verres 2.2.39 "Nothing was done if she willed otherwise." Livy says "Lucius Antonius, the consul, influenced by Fulvia, made war upon Caesar." And this device is employed to full effect on Antony. Fulvia is used as an agent of control

\footnotetext{
${ }^{16}$ Cic., Parad., 34.

${ }^{17}$ Hillard, "Republican Women, Politics, and the Evidence," 167.

${ }^{18}$ Ibid., 168.
} 
over Antony's mind, his body, and his business affairs. ${ }^{19}$

In order for Antony to be believably taken by Fulvia, her motives must be part of

the invective. For Cicero, Fulvia is a commanding force driven by avarice. Phil. 1.33

states quamquam solent domestici depravare non numquam ["sometimes those in his

household are accustomed to corrupt the man"] and Antony's household and its role in

his corruption is repeatedly called into question by Cicero. Phil. 2.95 accuses Antony of

having Fulvia conduct business in the name of Rome while implying that said business

was decidedly not appropriate.

"And in what words? At one time he says, "that it appears to him to be just," at another, "that it appears not to be unjust..." What a strange combination of words! But while alive (I know this, for I always supported Deiotarus, who was at a distance), he never said that anything which we were asking for, for him, appeared just to him. A contract for ten million sesterces was entered into in the women's apartment, in which place many things have been sold and are being sold, through ambassadors, good men, but timid and inexperienced, without my opinion or that of the hereditary friends of the ruler."

at quibus verbis? modo aequum sibi videri, modo non iniquum. mira verborum complexio! at ille numquam — semper enim absenti adfui Deiotaro- quicquam sibi quod nos pro illo postularemus aequum dixit videri. syngrapha sesterti centiens per legatos, viros bonos, sed timidos et imperitos, sine nostra, sine reliquorum hospitum regis sententia facta in gynaecio est, quo in loco plurimae res venierunt et veneunt.

\footnotetext{
${ }^{19}$ Livy, 125; Dio, 48.4 alleges that Lucius Antony required Fulvia's permission to hold a triumph and that he was under her control to such a degree that she was truly consul of Rome. "This was what took place then. The following year Publius Servilius and Lucius Antonius nominally became consuls, but in reality it was Antonius and Fulvia. She, the mother-in-law of Caesar and wife of Antony, had no respect for Lepidus because of his slothfulness, and managed affairs herself, so that neither the senate nor the people transacted any business contrary to her pleasure. At any rate, when Lucius urged that he be allowed to celebrate a triumph over certain peoples dwelling in the Alps, on the ground that he had conquered them, Fulvia for a time opposed him and no one was for granting it, but when her favor was courted and she gave permission, they voted for the measure unanimously; therefore, though it was nominally Antonius who celebrated a triumph over the people whom he claimed to have vanquished (in reality he had done nothing deserving a triumph and had held no command at all in those regions), yet it was actually Fulvia. At all events, she assumed a far prouder bearing over the affair than he did, because she had a truer cause; for to give any one authority to hold a triumph was a greater thing than to celebrate one which had been received at another's hands. Except that Lucius donned the triumphal garb, mounted the chariot, and performed the other rites customary in such cases, it was Fulvia herself who seemed to be giving the spectacle, employing him as her assistant."
} 
Weir notes that Cicero's use of the Greek word syngrapha, a contract for payment of a fixed sum in conjunction with the Greek word, gynaecium, the secluded women's quarters of a Greek house, connects the two in the listener's minds and implies payment for submission: i.e. sex. ${ }^{20}$ The contract for ten million sesterces that Cicero took issue with involved Fulvia's alleged participation in the April 44 'sale' the kingdom of Galatia back to its previous sovereign Deiotarus. Three years earlier Caesar had removed Deiotarus from power for being a partisan of Pompey. In a letter to his friend Atticus Cicero complained: "He [Deiotarus], of course, is worthy of any kingdom, but not through Fulvia." ${ }^{21}$ Cicero accuses Fulvia of using her wool working room, the quasilla, for accounting, saying "but at the house of this man gold was constantly being weighed out in the spinning rooms, and money was being counted; and in one house everyone who was interested was being sold the whole empire of the Roman people."22 Implying that Fulvia uses her quasilla to hoard gold instead of textile work fits nicely into Plutarch's description of Fulvia as a woman "who took no thought to spinning or housekeeping." This is of course not a surprise considering Plutarch's use of Philippics as a source. ${ }^{23}$

Cicero goes so far in the Fifth Philippic as to proclaim that Fulvia's greed is so great, and Antony so dominated by her, that he forges documents while she sells off Rome's provinces and ransoms pardons to exiled citizens to satisfy her need for wealth.

quid? illi tot immanes quaestus ferendine quos M. Antoni exhausit domus? decreta falsa vendebat, regna, civitates, immunitates in aes accepta pecunia iubebat incidi... calebant in interiore aedium parte totius rei publicae nundinae;

\footnotetext{
${ }^{20}$ Pelling, "Plutarch's Method of Work in the Roman Lives," Journal of Hellenic Studies, 99 (1979), 89-90; Weir, "A Study of Fulvia," 67-70; JT Ramsey, Cicero: Philippics 1-2, (Cambridge: Cambridge University Press, 2003), 299.

${ }^{21}$ Cic., Att., 14.12.1, Deiotari nostri causa non similis? dignus ille quidem omni regno sed non per Fulviam

${ }^{22}$ Cic., Phil., 3.10. "at vero huius domi inter quasilla pendebatur aurum, numerabatur pecunia; una in domo omnes quorum intererat totum imperium populi Romani nundinabantur."

${ }^{23}$ Plut., Vit. Ant., 10.3; Pelling, "Plutarch's Method," 1979, 91.
} 
mulier sibi feliciorquam viris auctionem provinciarum regnorumque faciebat; restituebantur exsules quasi lege sine lege.

What? Are those so much enormous profits to be endured which the house of M. Antony swallowed up? He was selling fake decrees, kingdoms, citizenships, and having accepted money he ordered exemptions from burdens to be cut on bronze... In the inner chambers of his home markets of the whole Republic thrived. His wife, more fortunate for herself than for her husbands, was holding an auction of kingdoms and provinces: exiles were restored without any law, as if by law. ${ }^{24}$

Cicero also hints that Fulvia's greed may have done in Clodius and Curio. Fulvia's greed does not stop at forgery and corruption to generate profits; she is also greedy for power and bloodshed. Cicero alludes to Fulvia's participation in a decimation at Brundisium which he lays entirely at her feet. In the Third Philippic, Cicero writes:

A man, who under the roof of his host at Brundisium, had ordered so many most brave men and best citizens to be murdered; and as she stood by, the face of his wife was sprinkled with the blood of those dying before her feet. ${ }^{25}$

In the Fifth and Eighteenth Philippics he returns to the scene:

When those bravest legions had cried out against his promises he ordered centurions whom he thought felt favorable to the Republic to come to him at his house and then he ordered them to be murdered before his own feet and those of his wife whom this serious commander had taken with him to the army. ${ }^{26}$

At Brundisium in the lap of his wife, who was not only the most greedy but also the most cruel, he massacred the chosen centurions of the Martian legion. ${ }^{27}$

In action to being personal invective against Antony and Fulvia, the vivid detail in Cicero's description of Fulvia being bloodied by the death of the soldiers echoed recognizable epic details and characters. It was also founded on rhetorical principles and concepts regularly used by Cicero throughout his career, including in his role as

\footnotetext{
${ }^{24}$ Cic., Phil., 5.11.

${ }^{25}$ Ibid., 3.4, "quippe qui in hospitis tectis Brundisi fortissimos viros optimosque civis iugulari iusserit; quorum ante pedes eius morientium sanguine os uxoris respersum esse constabat."

${ }^{26}$ Ibid., 5.22 .

${ }^{27}$ Ibid., 3.18.
} 
prosecutor in the trial of Cataline and in Clodius' Bona Dea trial. Cicero describes the personal style and hair styling of the Catalinian conspirators during the trial as evidence of their crime, calling them "pueri delecati," pretty boys and implying effeminacy. This is a standard tactic in rhetoric and forensic oratory playing to audiences' "presuppositions and preconceptions." ${ }^{28}$ In arguing against Clodius' claims of supporting Libertas and piety, as a priest of Libertas, Cicero accused him of incest with his sister Clodia to show Clodius as burdened by perverse femininity caused by submissive acts. Cicero alleged Clodius engaged in giving oral sex which was a submissive status. ${ }^{29}$ In further damaging speeches Cicero compares Clodius to a female musician, a beautiful one, a play on his name. Cicero would describe Clodius' imaginary clothing, complete with "purple ribbons," to better visualize and draw out specific movements, and stereotypical elements. ${ }^{30}$ This is the same technique employed by Cicero describing Fulvia with blood on her feet and gown, splashing and splattering by Cicero and later, by Dio claiming she strove about "girded" and brandishing a sword. Inventing a character's costume in invective also played to the audience's knowledge of thematic epic characters.

In the second Philippic Cicero manipulates Fulvia's reputation in order to fit a rhetorical model he has constructed in a unique invective against Antony. The second Philippic was never given as a speech. It was meant to be circulated as a pamphlet in 44 BCE. Circulation as a pamphlet meant that it was to be received by a mixed audience of men and women and passed on in homes and social circles. Nancy Myers argues this makes Cicero shift his rhetorical framework towards the private sphere by using

\footnotetext{
${ }^{28}$ Leach, Eleanor Winsor, "Gendering Clodius,” The Classical World 94, 4 (Summer, 2001): 342-3.

${ }^{29}$ Leach, "Gendering Clodius," 346; Cic., Mil.

${ }^{30}$ Leach, "Gendering Clodius," 347-8.
} 
Antony's home and personal life, particularly his relationships with the women in his life, Volumnia Cytheris, Fadia, Antonia, Fulvia, and his mother Julia, to demonstrate Antony's lack of morality. ${ }^{31}$ Cicero's intent is to prove Antony lacks self-control, is subservient to women, and is disrespectful of traditional Roman values. In order to do this Cicero sets up a binary comparison of the women in Antony's life. Antony's mother Julia is described by Cicero as having to endure being treated by her son as an equal to a mime, Volumnia Cytheris. In 2.24 Cicero describes Antony's tour as tribune, which he alleges shames his mother before all of Italy and equates his mistress with a proper

\section{Roman matron:}

The tribune of the people was borne along in a chariot, lictors crowned with laurel preceded him; among whom, on an open litter, was carried an actress; whom honorable men, citizens of the different municipalities, coming out from their towns under compulsion to meet him, saluted not by the name by which she was well known on the stage, but by that of Volumnia. A car followed full of pimps; then a lot of debauched companions; and then his mother, utterly neglected, followed the mistress of her profligate son, as if she had been her daughter-in-law. $\mathrm{O}$ the disastrous fecundity of that miserable woman! With the marks of such wickedness as this did that fellow stamp every municipality, and prefecture, and colony, and, in short, the whole of Italy. ${ }^{32}$

In Philippics 2.99 Cicero accuses Antony of betraying his own family and the Republic by divorcing his second wife Antonia, whom Cicero proclaims a "most chaste woman" whom Antony slandered before her father and the whole senate by accusing Dolabella of adultery. Cicero claims this was done in order for Antony to continue his affair with Cytheris and to marry Fulvia, whom Cicero also claims Antony was treating as his wife. Myers also stresses Cicero's comparison of Antonia to Antony's first wife Fadia, a

\footnotetext{
${ }^{31}$ Nancy Myers, "Cicero's (S)Trumpet: Roman Women and the Second Philippic." Rhetoric Review, 22 (4, 2003): 338-9.

${ }^{32}$ Cic., Phil., 2.24. 58
} 
freedwoman. In the thirteenth Philippic Cicero brings up Fadia again to shame Antony for mocking Octavian's family background. ${ }^{33}$ Myers argues that by using real women as a rhetorical framework for his argument, Cicero was "turning contemporary women into myths" and intertwining "public civic and private social spheres, masculine and feminine roles, and oral and written discourses." ${ }^{24}$ Fulvia is used in this speech to emphasize Antony's lack of control over himself in his private life, and thereby his lack of auctoritas in his public role. Fulvia herself is not named. She is raised to a level of mythic proportions in being referred to as "your wife," "that woman," "that wife of yours" and "his wife." 35 In 2.11 and 2.113 Cicero connects Fulvia to the deaths of Clodius and Curio without naming her, but allowing readers to infer his meaning and form the opinion that Antony will be next. 2.11 asks, "But who was ever found before, except Publius Clodius, to find fault with my consulship? And his fate indeed awaits you, as it also awaited Caius Curio; since that is now in your house which was fatal to each of them." Antony will be undone by his private life, here specifically Fulvia, the administrator of his household. Next Cicero claims that Fulvia, though greedy, should give up one more husband for the sake of the republic.

But however you treat us, as long as you adopt those counsels it is impossible for you, believe me, to last long. In truth, that wife of yours, who is so far removed from covetousness, and whom I mention without intending any slight to her, has been too long owing her third payment to the state. The Roman people has men to whom it can entrust the helm of the state; and wherever they are, there is all the defense of the republic, or rather, there is the republic itself; which as yet has only avenged, but has not reestablished itself. ${ }^{36}$

\footnotetext{
${ }^{33}$ Myers, "(S)Trumpet," 343-4; Cic., Phil., 2.3; 13.10; “And does he venture to look down on any one because of the meanness of his birth, when he has himself children by Fadia?"

${ }^{34}$ Myers, "(S)Trumpet," 339.

${ }^{35}$ Cic., Phil., 2.44, 3.2, 3.6, 5.4, 5.8, 12.1, 12.2, 13.8.

${ }^{36}$ Cic., Phil., 2.113.
} 
Both 2.11 and 2.113 assert that Antony's fate is controlled by Fulvia and that the political fates of her previous husbands were also her doing. Myers claims this manipulation of Fulvia's role in the lives of public officials through her control over their households “transforms Fulvia into a scheming androgyne." Her motives are masculine, to control men in public service. Once this image is established in the minds of the public, Antony is described in open invective as being not only sexually attracted to Fulvia, so much so that he had an affair with her and threw out his lawful wife, but that he also left his lover Cytheris and truly loves Fulvia. Being a "love slave" to Fulvia is displayed in the love letter/messenger story. Cicero describes Antony as running from his post with Caesar "in Gallic slippers and a barbarian mantle" to Fulvia to declare his love and weeping from her joy. ${ }^{37}$ This scene depicts Antony abandoning his post, his mistress, his dignity as a Roman by dressing in attire beneath his station, and in total, his status as a vir.

Fulvia's control over Antony's mind, heart, body, and political will is a key factor in Cicero's emasculation of Antony in the collective Philippics. Myers adds that the attack on Antony's masculinity is enhanced by Cicero's assertion that Antony was not being stripped of his manhood, that he had lost it long ago to Curio. Cicero negates Antony's accomplishments as tribune, as consul, as military commander, and as Caesar's chief officer by saying that Antony has always been a man who would sell his allegiance and himself. Cicero claims the profligacy and bankruptcy Antony inherited from his father ruined his nature. When he was supposed to become a man, he instead became "a

\footnotetext{
${ }^{37}$ Cic., Phil., 2.76-78. Cicero ends this anecdote proclaiming "Oh the worthless man (for what else can I call him? There is no more suitable expression for me to use)! Was it for this that you disturbed the city by nocturnal alarms, and Italy with fears of many days' duration, in order that you might show yourself unexpectedly, and that a woman might see you before she hoped to do so?"
} 
harlot." According to Cicero, Curio rescued Antony from prostitution and treated him as a wife. ${ }^{38}$ And so Antony's marriage is one of inversion: he being the wife and Fulvia the husband.

Antony's submission to Fulvia's control was addressed in Plutarch's Life of Antony in a way that both established Antony's complete lack of control over himself as a man and set the stage for his downfall brought on by submission to Cleopatra. Maria Wyke claims that the image of the domineering Fulvia is an Augustan invention meant to explain Antony's downfall and undermine his legacy. She writes that "The potential for this form of invective to be transferred wholesale to the figure of Cleopatra is fully realized in Plutarch's biography of Antony, where the wife passes on to his whore a man

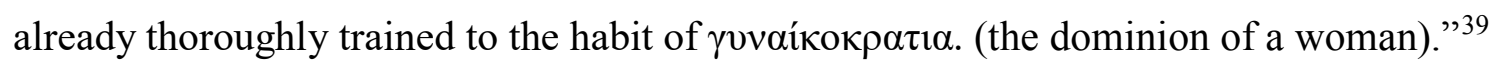
In 10.3 Fulvia made Antony "quite tamed to the dominion of women." Plutarch accentuates the theme of Antony surrendering his status as a vir by describing him in terms that imply he is a wild beast. When Plutarch described Antony's style of oratory as

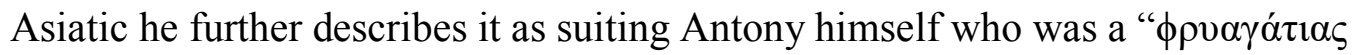
ravpí $\alpha$," a "hot-tempered, prancing horse." ${ }^{40}$ In keeping with the equestrian terms applied to Antony's spirit, Plutarch also uses the term $\chi \varepsilon \imath \rho \eta^{\prime} \theta \eta s$, meaning tamed, domesticated, literally 'accustomed to hands,' to break the spirit of a horse or other wild

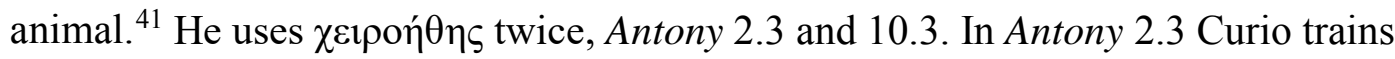

\footnotetext{
${ }^{38}$ Myers, "(S)Trumpet," 346; Cic., Phil., 2.44.

${ }^{39}$ Maria Wyke, The Roman Mistress, Ancient and Modern Representations, (Oxford University Press, 2007): 219-20.

${ }^{40}$ Pelling, ed., Plutarch: Life of Antony, (Cambridge: Cambridge University Press, 1988), 176; Plut., Vit. Ant., 3.1; Describing Antony's style of speech was also an account of his character. Seneca Epist., 114.4 states, "talis oratio qualis vita: style effects morals, morals effect speech." Asiatic style oratory was often associated with luxuria (degenerate lifestyle.)

${ }^{41}$ Liddell and Scott, An Intermediate Greek-English Lexicon, (Oxford. Clarendon Press)
} 
Antony to enjoy luxury and excess: "in order to make Antony more tame, [Curio] engaged him in drinking bouts, and with women, and in immoderate expenditures." Plutarch also uses $\chi \varepsilon 1 \rho \circ \eta \eta \emptyset \varsigma$ in Comparison of Demetrius and Antony to describe their ends:

As for their deaths, neither is to be commended, but that of Demetrius is the more to be censured. For he suffered himself to be taken prisoner, and was well content to add to his life three years of imprisonment. He was tamed, like a wild beast, by way of his belly and by wine. Whereas Antony took himself off-in a cowardly, pitiful, and ignoble way, it is true, but at least before his enemy became master of his person. ${ }^{42}$

This term is used by Plutarch throughout his corpora of work to lessen the status of the people he describes. Xєıрoи́ $\theta \eta \varsigma$ is generally not applied to people but to animals by most authors. Herodotus in Histories 2.69 claims that every household in Egypt raises trained

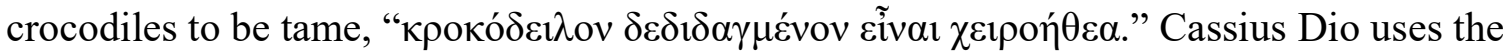
term, not to describe people, but animals being brought into Rome by Titus during the dedication of the hunting theatre he had erected over Augustus' Naumachia. ${ }^{43}$ Aelian uses it seven times in De Natura Animalium. ${ }^{44}$ Plutarch only applies $\chi \varepsilon \imath \rho \eta^{\prime} \theta \eta \varsigma$ in its traditional usage in The Life of Alexander in which Olympias tames snakes. He regularly uses the verb to describe the conquering, civilizing, or subduing of individuals or groups. The verb implies lowering of status and infers an animal nature to the 'tamed.' ${ }^{45}$ For example, in Agesilaus, Plutarch describes the civic mentality of Sparta as tamed: "For this reason it was, we are told, that Simonides gave Sparta the epithet of 'man-subduing,' since more than in any other state her customs made her citizens obedient to the laws and

\footnotetext{
42 Plut., Comp. Demtr. Ant., 6.2.

${ }^{43}$ Dio, 66.25.2.

${ }^{44}$ Aelian, De Natura Animalium, 3.46,9.4,12.29,12.30,13.17-18,17.5.

${ }^{45}$ Plut., Vit. Alex., 2.6.
} 
tamed $[\chi \varepsilon ı \rho \eta \mid \theta \varepsilon ı \varsigma]$, like horses that are overpowered while they are young." ${ }^{46}$ Here, the equestrian term is connected to the people while a second verb, $\delta \alpha \mu \alpha \zeta$ o $\varepsilon^{\prime} v o v \varsigma$, is applied to the horses. In Titus Flaminius Plutarch again uses $\chi \varepsilon 1 \rho \circ \eta \eta \emptyset \uparrow$, this time to describe Hannibal at the time of his death. In Life of Cicero, Plutarch uses the term to describe the fall of Lucius Antonius Hybrida (Mark Antony's uncle) to the intelligence of Cicero during the trial after the Catalinian conspiracy. ${ }^{47}$ And so by using $\chi \varepsilon \iota \rho o \eta ́ \theta \eta \varsigma$ in describing Antony's relationships with his friend Curio and his wife Fulvia Plutarch asserts their dominion over Antony. Not only is he being controlled, he is first trained to luxury and excess, then he is trained by a woman to enjoy being controlled by women. Plutarch implies that Antony is submissive, passive, and that he does not possess the higher qualities of the human spirit, but a tractable animal nature.

Implying that Antony can be controlled by Fulvia necessarily requires that Fulvia be controlling in order to be a believable piece of narrative evidence. To shift Fulvia's reputation from one of appropriate wifely devotion to domineering, Fulvia's status as a Roman matron must be challenged in the same way that Antony's status as a vir has been - through the lens of virtue. Fulvia's feminine virtues: pudicitia, modestia, obsequium, and lanificiam (chastity, modesty, obedience, and wool-working) are stripped away by Cicero in his claims of Fulvia's control of Antony in personal and public dealings, that she engaged in an affair with Antony while married to Clodius, that her house was ill-kept and a den of iniquity. ${ }^{48}$ Fulvia's deeds as an administrator of Antony's

\footnotetext{
${ }^{46}$ Plut., Agesilaus, 1.2

${ }^{47}$ Plut., Titus Flaminius, 21; Vit. Cic., 12.2.4, "This alarm Cicero first sought to allay by getting the province of Macedonia voted to his colleague, while he himself declined the proffered province of Gaul; and by this favor he induced Antonius, like a hired actor, to play the second role to him in defense of their country. Then, as soon as Antonius had been caught and was tractable, Cicero opposed himself with more courage to the innovators."

${ }^{48}$ Cic., Phil., 3.4, 10, 16; 5.11, 22; 6.4; 13.18.
} 
political campaigns, as accompanying him on military assignments, and being in command are not enough to damage Fulvia on their own. Even if she had done as Dio insists and issued orders to legions dressed in full military regalia, Fulvia's actions could be understood through the Roman concept of the virago. Viragos were women deemed "honorary men." The root of the word is vir. Viragos were women who displayed and exercised male virtues while maintaining feminine status, usually applied to women acting in male fields: war, politics, and public speaking. These women are seen to "transcend their sex" and employ masculine coded intelligence, cunning, and physical courage. For example, Hortensia, in giving her speech against taxation before the triumvirs, employed inherited masculine skill. She spoke with her father's eloquence. ${ }^{49}$ Turia, a woman of the late Republic, was also honored with masculine praise. She is described as possessing "undaunted courage" and "marshalling her words." She led an armed defense of her home when attacked by partisans of Milo. ${ }^{50}$

Fulvia meets the qualifications of a virago in action and appearance but has her motives challenged as masculine through invective proclaiming her to be ambitious and avaricious. ${ }^{51}$ And so Plutarch's claims about her character, that she could not abide "spinning or housekeeping nor would she deign to bear sway over a man of private station"52 are claims that Fulvia's virtues did not include obsequium (obedience)or

\footnotetext{
${ }^{49} \mathrm{~V}$. Max., 8.3.3, "By the faithful reproduction of her father's eloquence she succeeded in getting the greater part of the pecuniary impost remitted. Quintus Hortensius lived again in his female line. He breathed once more in the words of his daughter. If his male descendants had been willing to follow this vigorous example, the eloquence of Hortensius, so great a heritage, would not have been reduced to a single pleading of a woman."

${ }^{50}$ ILS 8393, A funeral eulogy. Rome, 1st cent. B.C. E. Line 9a: "Meanwhile when a troop of men collected by Milo, whose house I had acquired through purchase when he was in exile, tried to profit by the opportunities provided by the civil war and break into our house to plunder, you beat them back successfully and were able to defend our home."

${ }^{51}$ Hemelrijk, "Masculinity and Femininity in the "Laudatio Turiae," 191-2.

${ }^{52}$ Plut., Vit. Ant., 10.3.
} 
lanificiam (wool working). Lanificiam had larger implications than competency in textile work; it was a catch-all phrase that implied excellence in obligations of familial, community service, and household management. To say that Fulvia did not spin or work with wool is to say that she was no Roman matron, that she was hubristic or incompetent and refused the female responsibilities, rites, and rituals inherent in her status as a woman, a patrician, and the wife of a consul and triumvir. ${ }^{53}$

Fulvia as a historical character has her feminine qualities undone to the extent that Velleius Paterculus claims she was "a woman in nothing but her form." ${ }^{\text {54 }}$ Being female in body, despite her femininity being questioned, Fulvia was still subject to Roman notions of active/passive sexuality and chastity. Her chastity is challenged by Cicero's allegations of an extra-marital affair with Antony. ${ }^{55}$ There is also supplementary material and textual evidence surrounding the Perusine War that impugns Fulvia's chastity and femininity. According to Dio (48. 4-10), Fulvia was the commander and instigator of the conflict, acting in word, deed, and appearance as a general: "She girded herself with a sword, gave the watchwords to the soldiers, and often harangued them." ${ }^{56}$ Velleius Paterculus claims that Lucius Antony was immoral to such a degree that Fulvia did as she pleased in the camp:

Lucius Antonius, a partaker of his brother's vices, but destitute of the virtues that the latter sometimes showed, by accusing Octavius before the veterans, and by calling to arms those who had lost their fields in the prescribed distribution of the lands and the naming of the colonies, had collected a large army. On the other hand, Fulvia, the wife of Antony, who was a woman in nothing but her form, took

\footnotetext{
${ }^{53}$ Judith Lynn Sebesta, "Women's Costume and Feminine Civic Morality in Augustan Rome," Gender and History 9.3 (Nov., 1997): 529. Women's traditional role was custos domi or preserver of the household.

${ }^{54}$ Vell. Pat., 11.74.

${ }^{55}$ Cic., Phil., 2.48.

${ }^{56}$ Dio, $48,4-10$.
} 
part in the contest, and threw everything into armed strife and tumult. She had first fixed the seat of war at Praeneste." ${ }^{57}$

Plutarch says that when Antony had left Alexandria to prepare for an expedition against the Parthians, and landed in Phoenicia, he received "a letter full of lamentations" from Fulvia which caused him set sail for Italy with his two hundred ships. "While making the voyage he learned from friends who were fleeing that Fulvia had been the cause of the war, being by nature restless and headstrong, and hoping to tear Antony away from Cleopatra by stirring up commotion in Italy." ${ }^{58}$ Complementing the textual narrative of Fulvia as a commander are glandes or lead sling bullets inscribed with slogans and threats by Octavian's forces and an epigram recorded by Marital but reputed to be written by Octavian during this conflict.

As discussed in Chapter 3, Hallett contends that the glandes or sling bullets found at Perusia coupled with Martial's epigrams demonstrate Fulvia's status as a leader in the conflict. Both Fulvia and Octavian are equally represented by inscriptions on the glandes, which were used by both factions in conflict and employed sexual terms to describe the battle between factions. However, the equal representation of Octavian and Fulvia as leaders demonstrated by the bullets do not match the narrative version of Augustus' victory or Fulvia's defeat as recounted in Dio. Additionally, by the time Martial wrote epigram 11.20, the image of the Perusine conflict in the social consciousness of Rome had changed and was no longer viewed with the gravity it once commanded. During the years surrounding 41-40 BCE Octavian was struggling to overcome his effeminate and

\footnotetext{
57 Vell. Pat., 2. 74. Fulvia also is connected to Perusia in a military capacity found in Plut., Vit. Ant. 10.5-6; App., B. Civ., 5.4.33; Flor., 2.16.2. Dio, 48.10.4, is the only one to describe Fulvia as a military commander.

${ }^{58}$ Plut., Vit. Ant., 30.2 .
} 
cruel public image. Octavian was known for his military cowardice. Pliny quotes Agrippa witnessing Octavian hiding during the battle at Philippi while Antony fought to victory. This is significant to the Perusine conflict, as it was veterans of Philippi resisting Octavian. ${ }^{59}$ Hallett claims that the bullets and epigram are meant to masculinize Octavian and tear down Fulvia's reputation. The glandes found at Perusia are the only example of bullets marked with graphic sexual language and imagery meant to humiliate and "to vent feelings of military hostility." ${ }^{60}$ Sexual threats are explicitly made by the rival armies. Fulvia is threatened with rape and genital injury, as is Lucius. The glandes also represent the earliest recorded usage of the word landica (clitoris). One bullet is inscribed with the phrase "I aiming for Fulvia's clitoris." Contemporary literary allusion indicates this is the correct area to hit to "injure an energetic female." ${ }^{61}$ The bullets aimed at Octavian were also sexual in nature, threatening oral and anal penetration. Hallett claims this equalizes the two commanders. ${ }^{62}$

Martial's epigram 11.20 is widely accepted as transmitting an epigram written by Octavian at Perusia. It is one of many sexually themed propaganda elements produced by Octavian in response to equal propaganda spread by Antony and his supporters accusing Octavian of sexual perversion. ${ }^{63}$ Octavian's poem seeks to present Fulvia as an aberration, rather than a woman; as a joke. He does so using humor. The epigram reads: Caesaris Augusti lascivos, livide, versus sex lege, qui tristis verba Latina legis: "Quod futuit Glaphyran Antonius, hanc mihi poenam:

\footnotetext{
${ }^{59}$ Pliny, NH, 7.148.

${ }^{60}$ Judith Hallett, "Perusinae Glandes and the Changing Image of Augustus." AJAH 2 (1977): 151-5; Emilio Gabba, "The Perusine War and Triumviral Italy." Harvard Studies in Classical Philology 75 (1971): 140-4. Martial's epigrams were published under the reign of Domitian. Gabba writes that through the Augustan propaganda of the Principate and early empire that Augustus had distanced himself from the campaign because it was viewed by the senatorial class as an unseemly event.

${ }^{61}$ Hallett, "Perusinae Glandes," 155.

${ }^{62}$ Ibid., $156-8$.

${ }^{63}$ Suet., Aug. 68-69, Antony describes Octavian's sexually deviant religious themed dinner parties.
} 
Fulvia constituit, se quoque uti futuam.

Fulviam ego ut futuam? Quod si me Manius oret pedicem? faciam? Non puto, si sapiam.

'Aut futue, aut pugnemus' ait. Quid quod mihi vita carior est ipsa mentula? Signa canant!"

Absolvis lepidos nimirum, Auguste, libellos, qui scis Romana simplicitate loqui.

O critical reader, who peruses with a serious face certain Latin verses of mine, read six sexy lines of Augustus Caesar:

"Because Antonius fucks Glaphyra, Fulvia wishes me to fuck her in revenge. I fuck Fulvia?! What if Manius were to make a similar request?!

Should I grant it? I should think not, if I were in my senses.

Either fuck me, says she, or fight me.

When my penis is dearer to me than life?

Let the trumpet sound for battle!"

Truly, Augustus, you acquit my sportive sorties of licentiousness, when you give such examples of Roman simplicity. ${ }^{64}$

This "Fuck or Fight" stanza masculinized Fulvia to seek war in lieu of sex and assaulted her status as chaste by claiming she desired sex outside her marriage. This undermines her role in the war, shifting her motives from public to personal. In reading the poem alone without any historical sources, Fulvia is not in command; she is a distraught woman in a frenzy over her husband's infidelity. Hallett states that in this "Fulvia's alleged appropriation of the supreme male privilege in the relation of the sexes - that of taking the initiative in choosing a bedmate-here results in rejection, proving her a sexual failure who turned to fighting as a last resort." She is a foil to Octavian, the "manly warrior and sexual success." Fulvia here is a manly failure, denied a victory on the battlefield and denied sex. ${ }^{65}$

In Roman rhetoric and oratory the use of humor to undermine an opponent was well established and often used to call out questionable aspects of a subject's masculinity

\footnotetext{
${ }^{64}$ Mart., 11.20. Translation mine.

${ }^{65}$ Hallett, "Perusinae Glandes," 162.
} 
or femininity. There were specific evidentiary signs that orators used to convince an audience that inappropriate gendered behavior was taking place. The first category of signs relate to a person's visual self that they present to the public: their clothing style, hair, accessories. For men an obsession with grooming, careful hair arrangement, or obvious personal fashion sense were signs of femininity of nature. Actions could also be judged: the way a person laughs, sings, or dances, their manner of speaking, choice of sexual partners, sex acts, personal associates, and gestures. For men, wearing women's clothing (or just not male clothing) was a mark of aberrant sexual behavior or gender status. These signs can be applied to women as well. ${ }^{66}$ So for Dio in 47.10 .3 to describe Fulvia as "gird[ing] herself with a sword, giv[ing] out the watchword to the soldiers, and in many instances harang[ing] them," while occupying Praeneste, is to defeminize her. She is head of an occupying force, giving orders, wielding the weapon of a Roman soldier. This is built upon Velleius' claims that Fulvia is feminine only in form. He is implying that her thoughts, her ambitions, her deeds, her speech, her stride, her identity is masculine. He does not comment on her dress and weaponry. ${ }^{67}$ It is important to consider here that Dio presents Fulvia is in the costume of a virago, a noble woman warrior rising to battle with masculine valor. Had Cicero not sought to define her personality as commanding and greedy her actions might have been perceived as heroic, in defense of her husband's interests and in defense of his loyal veterans. But, whatever Fulvia's actual participation in the conflict, whether it was limited as claimed by Delia or whether she

\footnotetext{
${ }^{66}$ Corbeill, Controlling Laughter, "150-1-2; 160

${ }^{67}$ Dio, 47.10.3; Vell. Pat., 74.2. Similarly, Cicero and Plutarch attacked Antony's dress and style. In Cic., Phil., 11.26 Antony's bracelets/handcuffs are implied to be feminine decorations; he is also described as "loosely belted" in Plut., Vit. Ant. Discinctus= unbelted 'loose' of personal appearance or words, loose of morals.
} 
did raise eight legions and lead them, because of the loss of the battle and Antony's subsequent loss at Actium, Fulvia's reputation was destroyed. By adding in female motives, like jealousy (and a distraught, passionate sexuality according to Marital), Appian and Dio show Fulvia as a monstrous individual with male capabilities, a male mind, and female weaknesses. Hemelrijk claims Fulvia is depicted as a virago in sources but because her feminine virtues were negated she became an "androgynous monster." 68

Why was a total destruction of Fulvia as a leader needed in addition to the undermining of her femininity? If Cicero had done his work in using greedy, bloodthirsty Fulvia to undermine Antony's reputation, why is the story of Fulvia as an aberrant woman continued in the histories of the Perusian war? This was necessary because of Antony's powerful status as a triumvir and eastern autocrat and because of the way he had incorporated Fulvia into his political campaign and image. She was connected to him in the minds of the public and as a reflection of his political power and influence, and his victories as a commander. The public role of women changed to such a degree during the Augustan age that actions taken by women during the republic were viewed in a negative light. While women were used in art, coinage, and monuments during the Augustan age they represented the private sphere, domesticity, "fecundity, abundance, and familial continuity." Kleiner argues that these ideals were not politically relevant during the Republic. Conversely, Antony's use of women in coinage and marriage reflects the political power they wielded. Antony used women "not as illustration of feminine virtues but because they were involved in significant events, wielded influence over their

\footnotetext{
${ }^{68}$ Hemelrijk, "Masculinity and Femininity," 193-4.
} 
husbands' actions, or because association with these women was politically advantageous by a man." ${ }^{\circ 9}$

Marriages were alliances between men, their families and their extended client networks. Antony used the powerful women in his life to advance his own status and was not shy about it. He used a medium he already employed to success, coinage. In 44 BCE, Ides of March coins depicting a mourning Antony in beard and veil circulated. In 43 BCE in Transalpine Gaul a second mint issued coins of Antony in full mourning beard. Antony married Fulvia at the height of his career and used her image to represent his successes. Between 43-42 BCE coins (quinarius) were issued in Lugdunum, Antony's headquarters in Gaul. The quinarius has Fulvia as the goddess Victory on the obverse and a lion representing the Antonii on the reverse. In $40 \mathrm{BCE}$ similar coins were issued in Fulviana, Phrygia, a city named for Fulvia after Antony's stay in the area. This coin also bears Antony's name and the familiar lion on the back. The original quinarius from Gaul does not bear Antony's name or title. Kleiner believes that the image of Fulvia sufficiently represented Antony and so his name was not necessary. After Perusia Octavian's propagandists went to work on a campaign of image reformation to shift the public morality towards more traditional ideas about virtue, gender, sexuality, and appropriate behavior. Blaming Fulvia for the Perusine conflict helped demonstrate the need for Augustan legislative reforms that realigned acceptable standards of men and women within marriage, limited divorce, and made adultery a public crime. ${ }^{70}$

In Rome in 40 BCE aurei with Victory/Fulvia were minted with an armed warrior

\footnotetext{
${ }^{69}$ Diana E.E. Kleiner, "Politics and Gender in the Pictorial Propaganda of Antony and Octavian," Echoes du Monde Classique 36,11 (1992):357.

${ }^{70}$ Kleiner, "Politics and Gender," 358-61.
} 
on the obverse. Antony's use of coins depicting himself with Octavia and Cleopatra are not echoed by Octavian. Women and the power they wielded and represented were part of Antony's political strategy in a way not utilized by Octavian. Augustus' version of history relies on the tridiagonal view of women and foreigners as similarly below the status of the Roman male, "and the idea that Roman male would allow himself to be dominated by a woman," especially a foreign woman in the case of Cleopatra. Augustan propaganda reframes history because it was crucial to depict Antony as submissive and Augustus as the unquestioned truly Roman victor. In order to achieve this goal Augustan art portrays women not as politically important but as the fertile producers of male heirs, as shown on the Ara Pacis. Plutarch writes that Cleopatra "melted and feminized" all that was Roman about Antony. ${ }^{71}$ This concept also reinforces that idea Antony's marriage to Fulvia was a complete reversal of the normal roles of men and women in a marriage: she taught and controlled him, she limited or expanded his excesses as she saw fit, she fought campaigns without his consent or knowledge. The Augustan marriage and gender role realignment to a more traditional and idealized form necessarily casts Fulvia in a diminished and unacceptable role as a Roman woman and as a wife.

Part II: Rhetoric, Philosophy and the Impact of Genre Specific elements of invective and historiography interpreted by authors as factual elements of evidence representing a historical reality are rhetorical devices used to lead a listening audience to a specific conclusion designed by the orator or author. Rhetorical practice allowed for the creation of detail to use as evidence and the 'embroidery' or

\footnotetext{
${ }^{71}$ Kleiner, "Politics and Gender," 365-6; Plut., Ant., 53.11.
} 
embellishment of legitimate detail to suit the needs of the author. Rhetorical conventions and devices were a core component of Roman and Greek education and influenced authors of key sources in accessing the lives and deeds of Antony and Fulvia, particularly Cicero and Plutarch, though Appian and Dio are also guilty. In addition to influencing aspects of education, rhetoric was also a core means through which Romans interacted in public and private debate. Though an educated Roman or Greek man could recognize rhetorical constructions in context, elements of rhetoric are not as easily parsed when separated from the original context and incorporated into other genres. Additionally, as rhetorical styles change over the centuries, only specialists would have had the skill base to recognize obsolete practices. ${ }^{72}$ This means that authors writing in the late imperial period may not have been very well versed in Ciceronian rhetoric.

Rhetoric was crucial to the transition from republic to empire, beginning its influence on "social and political change" in the third BCE century with the Hellenization of Roman culture in Magna Graecia and Sicily. The assimilation of Greek systems of education into Roman communities was made stronger by the "extension of equal Roman citizenship [that] brought greater legitimacy to Greek intellectual style." ${ }^{73}$ By 146 BCE with the Achaean League falling to Roman conquest Sophists emigrated to Rome. Rhetoric did not have a direct flow of influence from Athens but from Western Greek colonies which filtered ideas into Rome. Rhetoric developed as political tool in Rome with a specific focus on kairos. Kairos represents the optimal social/political situation that shapes rhetoric; the opportunity or understanding the 'right time' to speak. The

\footnotetext{
${ }^{72}$ William J. Dominik, "The Style is the Man" in Roman Eloquence: Rhetoric in Society and Literature edited by William J. Dominik. (London: Routledge, 1997): 64.

${ }^{73}$ Richard Leo Enos, Roman Rhetoric: Revolution and Greek Influence, (Layfayette in: Parlor Press, 2008), 30-5.
} 
Republic became a politically deliberative government, formal in theory and practice.

Enos explains:

"Romans institutionalized the Senate and courts as formalized, communal mechanisms of Kairos - that is, as a sanctioned system for providing a public environment, within which problems could be resolved through discussion and debate. In the sense, Romans institutionalized Kairos and sought to have a stable society within which such systems could operate by providing a formalized de facto Kairos for rhetorical discourse." 74

Until 161 BCE the study of Greek oratory and rhetoric was generally opposed as opulent and idealizing Greek practices. Employing Greek methodology was considered to be scorning the Roman ideal and language. As late as 92 BCE, G. Domitius Ahenobarbus and Lucius Lucinius Crassus condemned Latin rhetorical practice as immoral. They favored declamatory style instead because of its malleability, utility, and ready adaptability to the Roman political environment. Eventually Romans used and appreciated Greek methodologies as long as they were Attic in origin and not from the Eastern schools or Asiatic style. ${ }^{75}$

Cicero as a writer and orator followed the Hermagorian Greek rhetorical tradition. This was mixture of stoicism, syllogism, and stasis theory. He read and followed Aristotle’s Synagộệ Tekhnộn, a compendium of early Greek rhetoric, and was influenced by Isocrates. It is thought by Kirby that Aristotle's lost dialogues were the basis for Cicero's De Oratore, which reads as a synthesis of Aristotle and Isocrates modified meet to Roman cultural needs. ${ }^{76}$ Cicero employs a three-part rhetoric of ethos, pathos, and logos. Ethos is the perceived character of the speaker conveyed through

\footnotetext{
74 Enos, Roman Rhetoric, 36-41.

75 Ibid., 42-5.

${ }^{76}$ John T. Kirby, "Ciceronian Rhetoric: Theory and Practice" in Roman Eloquence: Rhetoric in Society and Literature, ed. William J. Dominik, (London: Routledge, 1997): 14.
} 
appearance, movement, posture, gesture, tone and voice modulation, and speech content, form, evidence, and performance. ${ }^{77}$ Pathos is the emotional response of the audience to ethos. Logos is inductive or deductive logical inferences generated by speech content. For Cicero there are three goals of rhetoric: to teach, to charm, and to move to decision, action, perspective, or opinion. In De Oratore Cicero defends Greek rhetorical elements by separating his practice into "Attic" influenced technique rather than "Asiatic.",78 Cicero favors parallelism and paradox as rhetorical devices to draw a desired pathos or logos from an audience. Both parallelism and paradox require the speaker to create or describe scenarios in detail.

1. Parallelism: used to create inference and antitheses.

A: Structural/syntactic: comparison or contrast of verb forms or syntax.

(If $\mathrm{A}$ is correct, then $\mathrm{B}$; but not $\mathrm{B}$, therefore not $\mathrm{A}$. If I were afraid, I would be running but I am not running, therefore I am not afraid.)

B: Thematic/conceptual: juxtaposed compared/contrasted ideas. (either Q or R based on premise: Although we fear, nonetheless we must have courage.)

2. Paradox: Defying expectation.

(Not X but Y. Presenting the opposite of expectation sets listeners up to believe they are being given privileged information.) ${ }^{79}$

Rhetoricians Marcus Aper and Quintilian demarcate Ciceronian and postclassical rhetorical styles with embellishment of evidence or detail being the dividing aspect. Ciceronian rhetoric is rife with pleonasm, repetition, amplification, and marked by

\footnotetext{
${ }^{77}$ Kirby, "Ciceronian Rhetoric," 16.

${ }^{78}$ Ibid., 18-20. Remember Cicero explicitly describes Antony's style as Asiatic. Cicero believed that Asiatic style was a novelty for the unrefined, not adult men. Cic., Brutus, 325-7.

${ }^{79}$ Kirby, "Ciceronian Rhetoric,"22.
} 
"rhetorical extravagance," and lack of a core discipline. Postclassical rhetoric is terse in order to avoid amplification through embellishment at all costs; it favors loose use of words, structure, and is more flexible and inventive. ${ }^{80}$ Aullus Gellus, for example, hated Seneca and Quintilian because of their postclassical style. His style was proudly based in "archaism," the use of traditional words with 'antique' usage and employment of phrases no longer current. Seneca argued that no one style was superior, that different times called for different styles of language and usage ${ }^{81}$ Ciceronian rhetoric, particularly in declamatory and invective forms, supports the orators' right and ability to embellish details and create evidence if necessary. Understanding of Cicero's own life and his death has been colored by this device. Details of Cicero's life, death, and speeches used as evidence for his life and for the lives of Fulvia and Antony first existed as Cicero's own oral productions subject to rhetorical constraints and logical guidelines. Cicero's speeches in all genres are based in declamatory practice. The very nature of declamatory invention makes access to the truth limited. ${ }^{82}$

Cicero's work and life have been mined for information on Roman politics, culture, court system, biographic detail, and used in course criticism. Anecdotes retelling his death have been treated as subject for rhetorical instruction (specifically for declamation training) since death. The death of Cicero in Plutarch, Appian, Dio, and Livy can all be traced to three sources: Tiro, Cornelius Nepos, and Asinius Pollio. These histories were shaped by declamatory tradition. ${ }^{83}$ The death of Cicero is described by

\footnotetext{
${ }^{80}$ Dominik, "The Style is the Man," 64.

${ }^{81}$ Ibid., 65.

${ }^{82}$ Roller, "Color-blindness," 110.

${ }^{83}$ Matthew B. Roller, "Color-blindness: Cicero's Death, Declamation, and the Production of History."

Classical Philology 92 (Apr., 1997): 115.
} 
Plutarch but he does not mention Fulvia apart from her daughter's marriage to Octavian. Appian adds that "Antony was delighted beyond measure. He crowned the centurion and gave him 250,000 Attic drachmas in addition to the stipulated reward for killing the man who had been his greatest and most bitter enemy." Likewise, Velleius Paterculus does not mention Fulvia or the mistreatment of his corpse but does describe the bonus (death-fee) paid by Antony to Cicero's assassins. Fulvia's absence from Velleius' narrative is striking, since he was as heavily influenced by Augustus' propaganda and as he was fond of Cicero. ${ }^{84} \mathrm{~A}$ fragment of Livy gives his account of the death of Cicero without Fulvia. ${ }^{85}$ Dio is the only writer to include Fulvia in this scene or to accuse her of mutilation of Cicero's corpse with her hairpins. ${ }^{86}$

Though the historiography of Cicero's death in both ancient and modern sources exists in many genres including biography, declamation, and epic, as far as the story of goes even if you strip away the detail there are still "implausible rhetorical touches." Cicero is the source of many of the defining events and character traits used to create the historical character of Fulvia; her life is also linked to his death. The most graphic description comes from Dio:

"When the head of Cicero was brought to the triumvirs (for he was captured and killed while fleeing), Antony heaped many bitter reproaches on it, and then ordered that it be put in a more conspicuous place than the others on the rostra, so that in the place where Cicero had been heard speaking against himself it might be seen, together with the right hand, as that also had been cut off. Before it was removed Fulvia took the head in her hands, and, after abusing it with bitter words and spitting on it, placed it on her knees, opened the mouth, drew out the tongue,

\footnotetext{
${ }^{84}$ Vell. Pat., 2.66.3; In 66.3-5 Velleius writes that Antony will be damned for Cicero's death. And claims that he "accomplished nothing, I say, by offering a reward for the sealing of those divine lips and the severing of that illustrious head." He then praises Cicero's memory and accomplishments.

${ }^{85}$ Sen., Suas. i. 7.

${ }^{86}$ Plut., Vit. Ant., 20.2; App., B. Civ., 44.20.

${ }^{87}$ Cf. Rawson, 293-5.
} 
and pierced it with pins that she used in dressing her hair, all the time heaping disgusting epithets upon it." 88

This anecdote uses two prominent rhetorical devices: colores and cruciatus describere. It also implies immorality. The core of declamation is morality. Rhetors teach that presenting an argument as ethical has the best outcome. Ethical declamation allows for the use of colores or colors to support argument. A color is a supporting device that provides the audience with additional information, a framework, a lens, to 'color' the argument. Any idea, event, remembrance, allusion, or anecdote can be used as long as it does not contradict other evidence being used. It does not require truth. Typical color was the "assertion of an attitude." For example, if a rhetor argues that an event was necessary, all evidence which followed would prove necessity, such as explanatory vignettes supporting this claim. ${ }^{89}$ Ethical declamation can also pit two values against one another for consideration. Moral claims include: rectum, honestum, an oportet, utile, tutum, an possit, necesse (rightness, honesty, expediency, safety, feasibility, necessity.) There is a strict hierarchy of argument organization. Quintilian recommends pitting truth against expediency. Utilitarian arguments require that they are morally right or at least indifferent. While rhetoric supports the use of truth as an argument basis, it does not require that evidence to support that claim be true. A rhetor or orator merely need to evoke a pathos from the audience that convinces them truth is a justifiable motive. Similarly, no persuasive declamation can be made without evoking an ethical basis or evidence. Ethical grounds can be used in conjunction with other criteria but are essential to success. Quintilian teaches that a defense based on moral

\footnotetext{
${ }^{88}$ Dio, 48.8.

${ }^{89}$ Roller, "Color-blindness," 109-13.
} 
action is also the host effective. ${ }^{90}$

Both Quintilian and Seneca taught using Cicero’s death as a theme. This topic provides evidence of the nature of rhetorical evidence transmission and the dangers such evidence produces when removed from declamatory texts into biography and historiography. Polemical elements in early imperial rhetorical texts on the death of Cicero suggest contemporary sources, such as Asinius Pollio. Pollio claims in Pro Lamia that Cicero offered to support Antony in speeches and to destroy and retract the Philippics in exchange for his life and This anecdote is the basis for generations of declamatory material used to educate Roman students on argument and use of moral choices as evidence to support claims. Seneca reports this is the only declamatory source to imply that Cicero was in the wrong, that his speeches should be forfeit. ${ }^{91}$ In further prompts reported by Seneca Antony is described as a drunk Eastern king bent on malevolence. Additionally most prompts implicate Antony as sole official orchestrating proscriptions so that the rhetorical "Moral construction of Cicero's death" implicates Antony and his motives, and forever links them. ${ }^{92}$ Declamations are rife with ProAugustan propaganda themes: Antony's drunkenness, immoderation, un-Roman and antiRoman behavior, all elements lifted from the invective Philippics. Roller writes that "the overwhelming Pro-Ciceronianism of the preserved fragments suggests that most or all of these fragments post-date Actium, for the canonization of Cicero as the acme of eloquence and the vilification of Antony proceeded apace in a fully Augustan context."93

\footnotetext{
${ }^{90}$ Roller, "Color-blindness," 115 . Roller argues "in declamation, a moral understanding of events is the primary mode of understanding; ethical appeals are more authoritative and persuasive than appeals on any other grounds;" Quint., Instr. 7.4.4.

${ }^{91}$ Sen., Suas, 6.15.

92 Roller, "Color-blindness," 116; Sen., Suas 6.3.

${ }^{93}$ Roller, "Color-blindness," 117-8.
} 
Declamatory rhetoric was the core of Augustan literary culture due to its centrality in education during the Triumviral period and Principate. Its usage and themes continued to be popular with the first generations of writers during the early Imperial period as well. This combination calcified Augustan propaganda and as a result, declamatory devices and expressions are found in all non-declamatory genres and texts from this period. ${ }^{94}$ Declamatory elements:

Sententia: inversion: the ironic use of words to reveal 'shocking' information, verbal novelty, irony in description. For example: Antony desiring Cicero's head and hands after his proscription when Antony had never valued anything either had produced when Cicero lived.

Expressive diffusion: repetition of grammatical structure or echoing elements of structure.

Cruciatus Describere: vivid description of violence to the body, particularly torture, bodily injury, expulsion of bodily fluids.

Dio's description of Fulvia cradling Cicero's head, pulling out the tongue and piercing it with pins is an example of Cruciatus Describere. So is Cicero's description of Fulvia's face and feet being spattered with blood. ${ }^{95}$

During Seneca's lifetime declamation is no longer an acceptable methodology because of the lack of evidentiary necessity. The creation or embellishment of evidence to support a rhetorical framework was a core element of declamation and avoided. Roller claims that by the standards of historiographic practice of Seneca and Quintilian the works produced in the generation after Actium are "Pro-Cicero polemics." ${ }^{96}$ For the generations of writers and orators after Actium Cicero is used as an archetype of the

\footnotetext{
${ }^{94}$ Roller, "Color-blindness, 120.

${ }^{95}$ Dio, 48.8; Cic., Phil. 3.4

${ }^{96}$ Roller, "Color-blindness," 120-124, Sen., Controv. 2.5.6 argues that Anti-Antony Polemics include: Vergil, Aeneid, 8.675-7.28; Hor., Ep., 9.11-6; Prop., 2.16.37-40; Mart., Epigrams, 3.66, 5.69; Vell. Pat., 2.66, 2.85; Dio 50.4-5, 24-27.
} 
'moral orator,' an intellectual hero. This bias is reproduced in declamatory evidence removed from its context and cited in other genres as legitimate evidence. Roller marks Plutarch's Life of Cicero 48.1 as an example of an embellished or 'colored' declamatory element used as fact. Plutarch repeats an allegation that Popillius, the man who executed Cicero, was tried on charges of parricide because of his role in killing the writer. This claim is based on a completely fabricated scenario of Cicero's death created as a declamatory exercise in which Cicero was also Popillius' patron. Students were able to use this scenario to argue the potential moral choices of Popillius' actions: should Popillius have betrayed his patron by following the orders of his general and a triumvir, or should he have betrayed his duty and his country by sparing his patron, who acted like his father? There is no evidence that Popillius was the executioner, that Cicero was his patron, or that he was tried in any way. Popillius is described as a centurion in Appian's account and a tribune in Plutarch. ${ }^{97}$ Unfortunately, even when elements of declamation are moved into more rigorous genres, they still contain elements of declamatory invention. When using speeches, they must be treated in context rather than mined for detail and integrated into narrative. This is necessary because only the original context of a declamatory text suggests elements are embellished evidence; it suggests fictional status or creation. When removed from context and treated as independent, the rhetorical evidence is granted status as factual. This type of evidence transference was acceptable for early historians of the Principate and Imperial periods, writers for whom "history is for the most part a record of the moral significance of events." ${ }^{98}$ Declamation and the transmission of embellishment mar Roman and Greek histories to such a degree that in

\footnotetext{
${ }^{97}$ Plut., Vit. Cic., 48.1; App., B. Civ. 4.19.

${ }^{98}$ Roller, "Color-blindness," 124.
} 
his commentary on Cicero, D.R. Shackleton-Bailey claims that Plutarch is not a reliable source because of the degree of embellishment he employed. ${ }^{99}$ Plutarch's use of embellishment, embellished sources, and invective as evidence is clear. The first three chapters of the Life of Antony are lifted directly from the Second Philippic; Plutarch essentially expands Cicero's calumny into a biography of Antony. Pelling asserts that the "writing [of the Second Philippic] is so clearly tailored to the interests and themes of the present Life [of Antony]." Elements are exaggerated and expanded for effect. For example, Antony is more led by Curio according to Plutarch than according to Philippic 2.44-7. While Cicero called them equal in excess, Plutarch has Antony pander to Curio (to be trained by him) as a set up for domination by Fulvia, who in turn is a set up for the 'magic' worked on him by Cleopatra. ${ }^{100}$

Rhetoric also plays a key role in another event linked to Fulvia. Richlin writes that rhetoric and rhetorical schools were "a locus of gender construction, a place where manhood is contested, defended, and indeed produced." ${ }^{101}$ Women were not orators in the same way that they did not control public affairs. It was occasionally possible for a woman to publicly employ rhetoric and oratory but, like warfare or political campaigning, it must be for reasons that are not feminine in nature or do not support the female speaker's own interests alone. As case in point is the oft referenced Hortensia,

\footnotetext{
${ }^{99}$ D.R. Shackleton-Bailey, Cicero: Classical Life and Letters (Duckworth \& Co Ltd, 1971): 277.

${ }^{100}$ Pelling, "Plutarch's Method in the Roman Lives," in Essays on Plutarch's Lives, ed., Barbara Scardigli, (Oxford: Clarendon Press, 1995), 297-8.

${ }^{101}$ Amy Richlin, "Gender and Rhetoric Producing Manhood in the Schools," in Roman Eloquence: Rhetoric in Society and Literature edited by William J. Dominik. (London: Routledge, 1997): 90. Richlin quotes Justinian to demonstrate the changed views of women's use of rhetoric during the late empire: "It is prohibited to women to plead on behalf of others. And indeed there is reason for the prohibition: lest women mix themselves up in other people's cases, going against the chastity that befits their gender, and lest women perform the duties proper to men."
} 
daughter of Quintus Hortensius. Hortensia is known for speaking before the triumvirs during the proscriptions on behalf of matrons who had been issued tax on their personal property. Hortensia, accompanied by the matrons, first tried to speak "with the sister of Octavius and the mother of Antony they did not fail, but they were repulsed from the doors of Fulvia, the wife of Antony, whose rudeness they could scarce endure." ${ }^{102}$ Only when the women's social network (part of the private sphere) of Rome failed, through Fulvia refusing to use her influence did Hortensia turn to oratory in the public sphere. Oratory, public speaking in service of the public, aligned with masculinity, but Hortensia was seen to overcome this because of her intent and the style with which she carried out her actions. Valerius Maximus writes of Hortensia:

By the faithful reproduction of her father's eloquence she succeeded in getting the greater part of the pecuniary impost remitted. Quintus Hortensius lived again in his female line. He breathed once more in the words of his daughter. If his male descendants had been willing to follow this vigorous example, the eloquence of Hortensius, so great a heritage, would not have been reduced to a single pleading of a woman." 103

The speech of Hortensia is accepted because she was thought to be speaking with the support of her father and what thought to be his views. This anecdote is also used to exemplify Fulvia's markedly unfeminine behavior in turning away the matrons of Rome, presumably because Appian and Maximus imaged Fulvia supported any means through which Antony could levy funds. In Appian's recounting Hortensia claims Fulvia "compelled" her to give a speech due to "having suffered unseemly treatment on the part of Fulvia[.]" ${ }^{\prime 104}$

\footnotetext{
${ }^{102}$ App. B. Civ., 4.5. 32;

${ }^{103}$ V. Max., 8.3.3.

${ }^{104}$ App. B. Civ. 4.5. 32.
} 
Embellishment also extended to anecdotes. Anecdotes were usually added to moral or historical exempla. ${ }^{105}$ Anecdotes used to depict Antony's lack of self-control (Fulvia being secretly delivered a letter by Antony), the corrupt nature of the triumviral period (Fulvia denying Hortensia during the proscriptions), and the death of a literary hero (Fulvia stabbing Cicero's tongue with her hairpins) all make their way into the life of Fulvia despite anecdotes being unprovable and likely fabricated. Anecdotes are generally untraceable and variable elements such as chronology, setting, character status, and dialog vary from example to example: the only constant is the moral of the story. ${ }^{106}$ The reality of reported details is secondary to the moral; details can be manipulated to enforce a moral or to demonstrate morality. Because of the nature of anecdotal evidence and rhetorical framework, after the fourth century BCE all biography was partially fictional. ${ }^{107}$ Fictional creation of detail was necessary to provide readers with detail that could rarely be verified or was rarely documented like a subject's education, aspects of his or her love life, or their personal character. Authors rarely admitted that they had created anecdotal detail but sometimes did include a few words about a story being fabula or dicitur. Plutarch adds an addendum after Antony 10.4-5 following the anecdote of Antony as his own messenger.

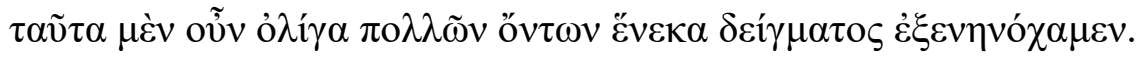
Indeed, from these few details of many, I have rendered a pattern.

As discussed this anecdote is meant to do demonstrate Antony's subservience to Fulvia and her desires. The lines before this addendum read, "Then Fulvia, in great distress,

\footnotetext{
${ }^{105}$ Richard Saller, "Anecdotes as Historical Evidence for the Principate," Greece \& Rome 27.1 (Apr., 1980): 69 .

${ }^{106}$ Ibid., 79-81.

${ }^{107}$ Ibid., 173.
} 
before taking the letter, asked whether Antony was still alive; and he, after handing her the letter without a word, as she began to open and read it, threw his arms about her and kissed her." ${ }^{108}$ This scene originally draws from Cicero's second Philippic reading:

He [Antony] is at once taken to the woman for whose sake he had come; and he delivered the letter to her. And when she had read it with tears (for it was written in a very amorous style, but the main subject of the letter was that he would have nothing to do with that actress for the future; that he had discarded all his love for her, and transferred it to his correspondent), when she, I say, wept plentifully, this soft-hearted man could bear it no longer; he uncovered his head and threw himself on her neck. Oh the worthless man (for what else can I call him? There is no more suitable expression for me to use). ${ }^{109}$

Cicero advocated the creation of rhetorical embellishment and said that examples in exempla and anecdote should be fabricated. ${ }^{110}$ While Plutarch's transmission is largely unchanged, other authors are not as interested in replicating detail: Dio has been known to distort an example "almost beyond recognition." "111 For many anecdotes it is impossible to consider the original narrator's motives or biases as original authorship is often impossible to assign. Additionally, it is important to consider that for ancient historians and moralists, if the desire to 'fact-check' an anecdote struck them, someone like Dio would have been even less able to check sources than a modern historian, because he most likely would not have thought falsification or embellishment was an issue to correct against.

Another use of anecdote was exploration of stereotype. Augustus was a fan of moral stories. Moralia deliberately use exempla to explore stereotypes. Augusts himself

\footnotetext{
${ }^{108}$ Plut., Vit. Ant., 10.5

109 Cic., Phil. 2.78.

${ }^{110}$ Cic., Part. Orat. 11.40; Saller, 71.

${ }^{111}$ Saller, "Anecdotes," 79; Dio 57.21.5; Petronius, Satyricon, 51; and Pliny, NH, 36.195 all discuss an anecdote about a man who invented unbreakable glass. Petronius issues the story first about the glass and its invention; Pliny added additional detail dating it to the reign of Tiberius; Dio changes almost all elements of the story to fit to his claim of Tiberius being overly greedy and jealous.
} 
was used by Silver Age moralists as a stereotype of clementia (mercy) and usually compared to Caligula as a stereotype of crudelitas (cruelty). Cornelius Nepos, Aulus Gellus, and Valerius Maximus all published collections of exempla and anecdote. The unstable nature of anecdote, its transmission and uncertain original purpose means that they must not be used as facts. The anecdotes connected to Antony to demonstrate his perceived character flaws cannot be used to create a narrative biography or character portrait of Fulvia. Therefore scenes such as 'Fulvia and the hairpin' may be entirely fabricated. ${ }^{112}$

Dio as source for understanding Fulvia, Antony, or their circumstances is a dubious one that must be carefully scrutinized as being influenced by political ideology rather than moral philosophy. Dio claimed to be moved by the Emperor Severus and a grand divine inspiration to write his works. He felt his style of writing, which did not deliberately moralize nor have a didactic purpose, would enhance Roman history. During the ten years of research Dio put in to his popular histories he became obsessed with Octavian and the triumviral period in general. Gowing asserts that Dio's ideological bias towards Octavian and "his perception of Augustus did not always permit belief that Octavian could have done anything deserving reproach." ${ }^{113}$ Dio, along with Appian, is a core source of information on the Perusine war, which Plutarch treats in passing. ${ }^{114}$ Where Dio did not define his narrative by morality, Appian was intentionally didactic. He meant to demonstrate the price of peace, the cost of Rome's rule, through analysis of its

\footnotetext{
${ }^{112}$ Saller, "Anecdotes," 80-81. Anecdotes can be used to understand perceived prescribed behavior and ideology but not to establish facts or individual personalities.

${ }^{113}$ Alain M. Gowing, The Triumviral Narratives of Appian and Cassius Dio. (Ann Arbor:

University of Michigan Press, 1992: 30-6, 69.

${ }^{114}$ Plut., Vit. Ant., 30
} 
leaders, military conflicts, and through comparisons with the socio-economic and political statuses of other nations. ${ }^{115}$ Due to his uncritical use of Augustus' memoirs as his primary textual sources of the triumviral period, Dio is "less objective" than Appian who is more likely to include contradictory evidence because of his use of varying source material. Dio is prone to shaping the evidence to fit his narrative. His history reflects his personal "contemporary politics." His "intentions infer results." ${ }^{116}$ Both Appian and Dio approved of the monarchic government, though Appian was less willing to sugar-coat how that government came to be. Dio wholly believed that Octavian was a bold and just man, born to be king. He is consistently hostile in his treatment of Antony. He is fond of foreshadowing and uses fictional accounts to link unconnected events. For Dio, Antony's actions and character were not given fair or full evaluation or attention because "Antony per se was not important: Antony as Octavian's rival was." ${ }^{\prime 17}$ Antony was a literary foil. Dio claims that Antony's motive was always to be Caesar's heir. He employed autocratic schemes to oppose Octavian in pursuit of this goal. Appian varies Antony's motives based on the context of the scene-ambition, fear, fulfillment of duty, loyalty, fear of assassination. $^{118}$

Fulvia is written as an extension of Antony. Dio uses Cicero's invective Philippics 3.4, 3.13, 3.18 (the decimation of the Martian army at Brundisium before

\footnotetext{
115 Gowing, Triumviral Narratives, 38.

116 Ibid., 47-9.

${ }^{117}$ Ibid., 104.

${ }^{118}$ Ibid., 105. Appian covers all of Antony's career but 35-33 BCE. His interpretation is more detailed and events are placed within their contexts rather than focusing on Antony as the reason for the narrative-he is one of many characters operating within event vignettes. Appian also draws heavily from Cicero, ex. B. Civ 51.15.2-3 and Cic., Phil., 2.40-41 both assess Antony's mind and actions, arguing that his actions were emotional, frivolous, and greedy - characteristics all coded as feminine. Gowing sites this attribution as the authors' attempt at class bias, an intentional portrayal of Antony as low class or as a rhetorical device to balance the texts' focus.
} 
Fulvia) to paint Fulvia as a militant woman out of control working to orchestrate her husband's ascendancy over Octavian. ${ }^{119}$ It is Dio who assigns the taking and occupying of Praeneste to Fulvia, where she is dressed and spoke as a commander (girded with a sword). ${ }^{120}$ This anecdote, along with Dio's account of Fulvia's conduct in regards to Cicero's head, has been influential in shaping the perception of Fulvia's character. Hillard offers basic guidelines for assessing women in rhetoric and invective: proceed with caution. "Evidence" concerning any type of public political activity or involvement is suspect because the information, transmitted as an allegation. Anecdotal evidence "highlights the unsubstantiated nature of each claim." Additionally, the women "concerned were politically irrelevant in that they were not the primary targets" of the invective. Instead all allegations against the women are a means "of attacking the politically potent" men related to them through marriage or blood. ${ }^{121}$ In working with histories containing anecdotes, Eric Gruen states nothing past names, reported actions, and potential dates are possible. ${ }^{122}$

If a moral rhetoric based on Roman ideals is the basis for Cicero's arguments, the philosophical state of the soul and its response to eros is Plutarch's. Plutarch uses eros as a "lens for both interpretation of historical sources and for his composition of political biographies" in an attempt to use ethics as explanation behind historic events and motivation. ${ }^{123}$ Plutarch was Platonist in his interpretation of subjects and motives (Platonists are anti-stoic). Plutarch used Plato's theory of the soul to interpret his

\footnotetext{
${ }^{119}$ Dio, $45.13 ; 48.4$

${ }^{120}$ Dio, 48.10.2.3.

${ }^{121}$ Hillard, "Roman Women,"174-5.

${ }^{122}$ Erich Gruen, The Last Generation of the Roman Republic, (Berkeley: University of California Press, 1974), 529-30.

${ }^{123}$ Jeffery, Beneker, The Passionate Statesman: Eros and Politics in Plutarch's Lives. (Oxford: Oxford Press, 2012): 3
} 
characters' responses to eros to demonstrate moral, mental, or physical fitness or unfitness. In Platonian theory morality is the rational dominance of passions. Plutarch's assessment of morality also follows Aristotelian model of the soul with two parts: reason

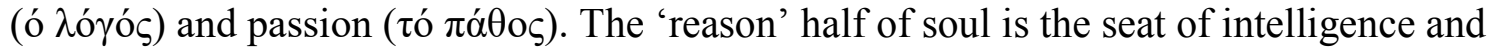
rationality while the 'passion' half is home to eros and irrationality. There are also two halves to the passionate portion of the human soul: the appetite and the spirit. The appetite is pure irrationality. The spirit is what causes emotional reactions to ideas presented to the mind and circumstances experienced by the body. The spirit on its own, responds with "anger, indignation, shame, and ambition" unless it is tempered and controlled by the rational elements of the soul. A person's behavior is the product of interaction of reason and passion. ${ }^{124}$ Plutarch believed that virtue and morality lie in finding the appropriate balance between the halves of the soul. In the moral person, rationality dominates irrationality. Emotions are viewed as diseases of the soul manifested by rational errors. Emotions were needed for fighting and reproduction must be controlled and disciplined by reason. ${ }^{125}$

Operating the soul in response to stimulus is a three-part process.

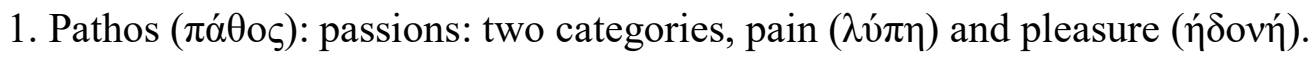

2. Capacity ( $\left.\delta v^{v} \alpha \mu \iota \varsigma\right)$ : response to passions. This is the step where rational intervention to control passions is possible.

3. Disposition ( $\left(\tilde{\varepsilon} \zeta{ }_{1 \zeta}\right):$ physical bodily presentation of response to passions. ${ }^{126}$

\footnotetext{
${ }^{124}$ Beneker, The Passionate Statesman, 3-10.

${ }^{125}$ Ibid., 16-17.

${ }^{126}$ Ibid., 20.
} 
Plutarch includes examples of eros in the Lives of Alexander and Caesar but they are able to rationally temper their passions. Antony and Demetrius are not. Antony is "so dominated by eros that it causes him to abandon political alliances, to take tactical blunders, and to ultimately lose his life." ${ }^{127}$ And he himself is at fault. He cannot control is disposition. For Plutarch innocence is only granted in absence of knowledge or education. He judges his subjects' actions based on consideration of whether they are ignorant of vice or ó $\rho \theta \omega ́ \varsigma$ - knowing immorality and choosing it. ${ }^{128}$ The Life of Antony is meant to be an example of a man's improper response to strong nature of spirit; Antony was controlled by eros.

Fulvia initially helped Antony by controlling him and helping to suppress his spirit but this is an inappropriate reversal of the marital relationship. It is irrational. Fulvia becomes more corrupted and more ambitious because Antony does not do his duty and impose rational control onto her behavior. Antony's tale is failure in the face of potential. He should succeed. Plutarch reports anecdotes of Antony's passionate relationships not to display the tragedy of romance but to symbolize Antony's lack of control, his making incorrect choices on small scale to show how he could fail on a large scale. The Life of Antony is not about how Antony was led (and led astray by women), but about the deficiencies in his character and actions that made is possible. Many of his virtues reveal themselves to be flaws that consume him. Antony is defeated by himself, not by Octavian. Beneker thinks The Life of Demetrius is only a foreshadowing device for The Life of Antony. Since Demetrius is "an erotically reckless but nonetheless successful

\footnotetext{
${ }^{127}$ Beneker, The Passionate Statesman, 125.

${ }^{128}$ Ibid., 126-47.
} 
general," Antony follows this model but descends further into passions and eventually succumbs. ${ }^{129}$ Pitting Antony against Octavian is a metaphor for passion against reason. Antony was an excellent general with enough support and manpower that he should have won. He lost because he lost himself.

\section{Conclusion:}

Where does this leave Fulvia? Fulvia as a historical figure cannot be recovered because of the layers of invective, rhetorical embellishment, and propaganda heaped upon her in service to the destruction of her husband. The need for Cicero, Plutarch, Dio, and Appian to undermine Antony's status as a vir and as a man of moral integrity required the use of anecdote and an ideological framework that shaped evidence to fulfill the requirements of that objective. Octavian's image reform coupled with his reforms of women's social and sexual status in the new empire made Fulvia into an ideal representation of a woman whose greed and lust transformed her into a masculine figure that does not reflect the real woman who died in 40 BCE. Chapter five follows Fulvia's image in popular histories including compendia of women in the ancient world, novels on ancient Rome, and romances of Antony and Cleopatra. This chapter assesses how popular sources interpret historical sources and scholarship to create varying images of Fulvia.

\footnotetext{
${ }^{129}$ Ibid., 155-6.
} 


\section{CHAPTER 5}

\section{“THANK FULVIA" OR, CLEOPATRA'S RIVAL}

This chapter follows Fulvia's popular image in mass-produced print: newspapers, plays, novels, early histories of Rome and studies of Ancient women. It traces Fulvia as a character developed in relation to Cleopatra and as Antony's wife, but it also demonstrates how Fulvia has been treated as a woman known for being politically and militarily active during the late Republic. For the past four hundred years, popular historians, playwrights, and novelists have used Fulvia as a character secondary to Cleopatra: an explanation for her or as a rival. ${ }^{1}$ Fulvia has also been used as a plot device to challenge the character of Antony. What will he do with wife causing trouble in Italy? Fulvia has been used by modern authors to try to explain the presence of suffragettes and feminists in their midst. She has been used as an icon of women's achievement and Girl Power. Depending on the motives of a given author Fulvia has been used to make Rome seem civilized or uncivilized, to make Antony into a hero or a villain, to prove that women have always been contenders in male fields of action or to show what happens when women meddle in men's business. In short: modern authors have used Fulvia just as their ancient predecessors did. They create and shape and mold and highlight and erase

\footnotetext{
${ }^{1}$ This discussion is limited to works on Antony and Cleopatra, works on Cleopatra in which Antony is heavily featured, collections or survey material on women in the ancient world, and popular works in which Fulvia is a main character.
} 
aspects of her character and personality as needed. With few exceptions, the Fulvia produced by the rigorous scholarship of historians, literary scholars, and rhetoricians is missing from the popular narrative of Fulvia's life. She is once again discussed as Antony's wife, as Cicero's enemy, as a masculine woman out of order.

Part 1: The Shrill Tongued Shrew/ Making a Virago ${ }^{2}$

An enduring part of Fulvia's ancient and modern perception by scholars and popular authors alike is the idea of Fulvia being a virago. Even when authors do not recognize Fulvia using the exact term, she is nonetheless described using terms drawn from the image of the virago. William Shakespeare is largely responsible for connecting Fulvia to the term and, to Fulvia's detriment, redefining the term to convey a bevy of negative female attributes.

Act. 1 Scene 2

Cleopatra to Antony: As I am Egypt's queen, Thou blushest, Antony; and that blood of thine Is Caesar's homager: else so thy cheek pays shame When shrill-tongued Fulvia scolds. ${ }^{3}$

Act. 2 Scene 2

Antony. As for my wife, I would you had her spirit in such another:

The third o' the world is yours, which with a snaffle

You may pace easy, but not such a wife.

Enobarbus. Would we had all such wives, that the men might go to wars with the women!

Antony. So much uncurbable, her garboils, Cæsar, Made out of her impatience, - which not wanted

Shrewdness of policy too,--I grieving grant

Did you too much disquiet; for that you must

\footnotetext{
${ }^{2}$ For Fulvia as a virago see Parker, "The Tetragenic Grid, 58-9.
}

${ }^{3}$ Shakespeare, Antony and Cleopatra, 1.1.36-39. 
But say I could not help it ${ }^{4}$

In Act. 1. Scene 1 of "Antony and Cleopatra," 1623, Shakespeare describes Fulvia as "shrill-tongued." Fulvia does not have lines or appear on stage but her presence looms over Antony's and Cleopatra's relationship. She harps on Antony from afar and he fears her nagging even in Alexandria. He can control one-third of the world but not his wife; her spirit is domineering and her policies would serve Rome well if she were a man and her actions not been tainted by a woman's impatience. The image of Fulvia as a scolding, nagging, controlling, terror alluded to by many modern authors is drawn from Shakespeare's Fulvia. Shakespeare, in turn, drew his Fulvia from Plutarch's Life of Antony and Life of Augustus in an edition printed and translated by Sir Thomas North in 1579. ${ }^{5}$ North did not read the original Greek but a French translation by James Amiot. ${ }^{6}$ North translated Plutarch's Life of Antony 10.3 as:

And therefore he [Antony] left his dissolute manner of life, and married Fulvia, that was Clodius' widow, a woman not so basely minded to spend her time in spinning and housewifery; and was not contented to master her husband at home, but would also rule him in his office abroad, and commanded him that commanded legions and great armies: so that Cleopatra was to give Fulvia thanks for that she had taught Antonius this obedience to women, that learned so well to be at their commandment. ${ }^{7}$

Fulvia is not described as serious but "sour and crooked of condition." Antony tried to make her "pleasanter and somewhat better disposed" by delivering his love letters to surprise her. ${ }^{8}$ Shakespeare's Fulvia also incorporates a popular literary and folklore motif of "the shrew." In European folklore a shrew is a wife who refuses submission to her

\footnotetext{
${ }^{4}$ Shakespeare, Antony and Cleopatra, 2.2.82-91.

${ }^{5}$ Walter. W. Skeat, Shakespeare's Plutarch: Being a Selection from 'The Lives' in North's Plutarch which Illustrate Shakespeare's Plays (London: MacMillan and Co., 1875): xii-xx

${ }^{6}$ Ibid., viii; Tim Duff, Plutarch's Lives: Exploring Virtue and Vice, (Oxford: Clarendon Press, 1999): 1-3.

${ }^{7}$ Skeat, Shakespeare's Plutarch, 162. The coordinating commentary foot note reads, "Fulvia ruled Antonius at home and abroad."

${ }^{8}$ Ibid.; Plut., Vit. Ant., 10.4-5.
} 
husband. She is strong-willed and vocal. Shrew-taming stories represent "anxieties about insubordinate female behavior" which is a threat to the patriarchal family system and communities at large. Medieval and early modern communities viewed an inappropriate balance of power within marriages as immoral behavior from both husband and wife: the shrew for upsetting the social order and the husband for allowing her behavior to continue unchecked. ${ }^{9}$ Shakespeare's elision of the character of Fulvia with the character of shrew changes the way modern writers and readers view and understand the Roman character of the virago.

Other female characters have been described as viragos, including Queen Elizabeth I and Olympias, mother of Alexander the Great. Carney writes that in scholarly interpretation of Olympias, like Fulvia, negative characteristics and pejorative adjectives always accompany any discussion of her political or military action. There is always conjecture about her motives, which are always described as negative and always personal. Additionally, Carney writes that only certain aspects of Olympias' historical character are dwelt on in contemporary scholarship: while ancient sources reference her personality and desire for revenge, modern sources focus on alleged madness and downplay revenge. Like Fulvia, Olympias' male contemporaries go without their personal motives questioned and have neutral narration by modern authors. Meanwhile Olympias is always described with "negative adjectives and adverbs," usually "coldblooded" and "blood-thirsty." 10 This mirrors descriptions of Fulvia, who is described as

\footnotetext{
${ }^{9}$ Louise O. Vasvári, "Examples of the Motif of the Shrew in European Literature and Film," Comparative Literature and Culture 4.1 (2002): 1-2.

${ }^{10}$ Elizabeth D. Carney, "Olympias and the Image of the Virago," Phoenix 47.1 (Spring, 1993): 29-55. Carney writes on page 32 in regards to misreading Olympias and its effect on historical discourse: "[B]e cause of our unbalanced reading of this particular historical figure, our interpretation of Macedonian political events has been distorted."
} 
“ambitious,"11 “fearsome,"12 “fiery,"13 “forceful,"14 “domineering,"15 “jealous,"16

"cruel" 17 and "furious." 18

Interpretation of women as historical figures requires cutting through layers of

bias and prejudice in sources which are built on conventions surrounding public and private life. ${ }^{19}$ For Olympias, "hostility" comes from sources that object to her personality as they interpret it." Plutarch describes her as "jealous and indignant" and accuses her of manipulating Alexander. Carney writes of the biased based on the assumption on the part of early scholars that Olympias should not be (or want to be) in public role or public space; doing so is "interference." ${ }^{20}$ One issue of bias is word choice and changes in usage. There is a key difference in translation and usage of the word virago from Latin to English. ${ }^{21}$ For Roman's a virago is a neutral term but describes a female person using male virtues; "a heroic maiden, heroine, female warrior." This is a term for a woman who

\footnotetext{
${ }^{11}$ Paul Chrystal, Women in Ancient Rome, (Gloucestershire: Amberley Publishing, 2014), 71; Victor Duroy, History of Rome and the Roman People, (Boston: Dana Estes and Charles Lauriat, 1884), 617; John Hazel, Who's Who in the Roman World, (Routledge, 2001), 113; Jack Lindsay, Marc Antony: His World and his Contemporaries, (George Routledge and Sons, Ltd., 1936), 220; Southern, Patricia. Marc Antony: A Life. (Gloucestershire, UK: Anberly Publishing, 2012), 78. Fletcher, Fletcher, Cleopatra the Great: The Woman Behind the Legend, (Harper Perennial, 2012), 196.

${ }^{12}$ Southern, Antony, 77; Chrystal, Women in Ancient Rome, 226; Fletcher, Cleopatra the Great, 231; Lindsay, Marc Antony, 221.

${ }^{13}$ Fulvia's "proud and fiery temper must have been lashed to fury," Scott, "Political Propaganda," 25; Sergeant, Cleopatra, 180.

${ }^{14}$ Southern, Antony, 78; Barry Strauss, Death of Caesar, 96; Sergeant, Cleopatra, 168; Weigall, Antony, 300; Lindsay

15 "Antony, of course, was fated to fall into the hands of a restless, scheming, domineering woman of this kind," Weigall, Antony, 190.

16"So then Fulvia, with the jealousy of a woman, inflamed Lucius to discord." Scott, "Political Propaganda," 25. Fulvia is described as jealous twice on page 24. Also, Southern, Antony, 186; Fletcher, 284; Sergeant, 151,167; Lindsay, Antony, 220.

${ }^{17}$ Sergeant, Cleopatra, 169; Weigall, Antony, 271; Mary Kittredge, Marc Antony, (NY: Chelsea House Publishers, 1988), 14.

${ }^{18}$ Lindsay, Marc Antony, 220. Additionally, both Weigall, Antony, 328, and Lindsay, Marc Antony, 220 describe Fulvia as a "stormy-petrel," a harbinger of trouble.

${ }^{19}$ Elizabeth D. Carney, "Olympias and the Image of the Virago," 33.

${ }^{20}$ Ibid., 34.

${ }^{21}$ Unhae Langis, "Virtuous Viragos: Female Heroism and Ethical Action in Shakespearean Drama"

Literature Compass 7/6 (2010): 397-411.
} 
overcame the negative aspects assigned to femininity and was heroic on male terms. It is exceptional. It can also denote male-like sexuality and masculine personality traits. ${ }^{22}$ In her study of Shakespeare's usage, Unhae Langis writes on the changes virago undergoes:

"The second definition is 'A man-like, vigorous, and heroic woman; a female warrior; an amazon,' with recorded usage from 1387 to the mid-1800s. The third and most prominent sense, 'a bold, impudent... woman; a termagant, a scold,' appeared simultaneously with the second and more positive meaning but has come to dominate and eventually outstrip it." 23

Modern English usage and translation is not neutral in aspect. The OED for virago now has the modern understanding and usage includes a woman who is domineering, violent, overbearing, scolds, is a "shrew," nags, is pushy. Merriam-Webster adds "loud overbearing woman." OED synonyms include "harridan, shrew, dragon, termagant, vixen, fishwife, witch, hellcat, she-devil, tartar, martinet, ogress, battle-ax, scold." 24 The Harper Collins English Dictionary defines virago as "a loud, violent, and illtempered woman; scold; shrew." It has the Latin definition as well, "(archaic) a strong, brave, or warlike woman; amazon." ${ }^{25}$ Carney writes that not all problems in interpreting female historical characters stem from the sources; cultural judgement, usage and inference of meaning outside of original context also creates bias. Authors discussing women in the ancient world often connect women's alleged motivations for public action

\footnotetext{
22 Parker, "Tetragenic Grid," 58-9.

23 "Virtue, from the Latin vir for manly courage and strength, was the mark of male excellence in Renaissance culture. Embodying both physical and moral strength through the famous figure of Hercules, virtue took on other values of courtly gentility and political prudence as the medieval warrior society was gradually transformed into the modern state. In inverse proportion to the expansion of male virtue, the conception of the virago underwent a corresponding constriction and decline from a manlike, heroic woman to a scold." Unhae Langis, "Virtuous Viragos," 398.

${ }^{24}$ OED Online, s.v. "virago;" Oxford University Press; The American Heritage Guide to Contemporary Usage and Style, (Houghton Mifflin Company, 2005), s.v. "virago," shrew / harpy / harridan / termagant / virago are synonyms.

${ }^{25}$ Harper Collins English Dictionary: Complete \& Unabridged, London: Harper Collins, 2012), s.v "virago."
} 
to private issues or emotions to make the deeds irrational. ${ }^{26}$ In assigning motivation to female characters for public or private actions, female motivation is often claimed to be greed, revenge, and jealousy, while male political action is done for the "greater good" 27 For example, Appian claims Fulvia is driven to fight at Perusia out of jealousy over her husband's affairs while Lucius Antony is fighting for Republican principles. ${ }^{28}$

Shakespeare evokes Plutarch's description of Fulvia as a domineering woman who controlled Antony, and through him influenced politics at Rome. ${ }^{29}$ Shakespeare alludes to Fulvia as an active participant in military campaigns. ${ }^{30} \mathrm{He}$ also creates a Fulvia that is shrill, domineering, and willing to wage war out of jealousy based on Plutarch's design.

Following Shakespeare, Fulvia next appears in The Dictionary: Historical and Critical of Mr. Peter Bayle, published by the London Royal Society in $1736 .{ }^{31}$ The Dictionary entry on Fulvia is five pages long and not only gives detail about her life and character as found in the traditional sources, but refutes issues of common belief about her. In addition to citing primary texts, the entry reflects the image of Fulvia as a virago, forcefully acting out of self-interest. Fulvia's entry begins with Velleius Paterculus' quote about Fulvia possessing nothing womanly but her body. ${ }^{32}$ The gentlemen of the Society take care to inform the reader that when Dio writes that Fulvia could only settle her feud with Octavian "by the sword" and that she "was girded with a sword," readers must put

\footnotetext{
${ }^{26}$ Carney, "Image of the Virago," 38.

${ }^{27}$ Ibid., 39.

${ }^{28}$ App., B. Civ., 5.3.19, 5.4.32.

${ }^{29}$ Shakespeare, Antony and Cleopatra, 2.2.120-121, Antony states that "Fulvia, / To have me out of Egypt, made wars here"; 1.3.31, Cleopatra on Fulvia: "I have no power upon you; hers you are."

${ }^{30}$ Ibid., 2.2.86, Enobarbus remarks "would that we all had such wives, that the men might go to war with the women;" 1.2.65, "Fulvia thy wife first came into the field." 1.2.131-132, Antony states about Fulvia "The business she hath broached in the state /Cannot endure my absence."

${ }^{31}$ Pierre Bayle, Pierre Desmaizeaux, Anthelme Tricaud, and Alexis Gaudin, The Dictionary: Historical and Critical of Mr. Peter Bayle Volume 3, (London: The Royal Society, 1736), 111-115.

${ }^{32}$ Ibid., 111; Vell. Pat; 2.74.
} 
aside the "preposterous" nature of the idea and accept that a woman did wear and use a sword. ${ }^{33}$ The cause of Fulvia's hatred of Octavian and the violence that ensued was "womanish passions;" the nature of the "womanish" passions were varied—both jealousy and sexual desire for Octavian are cited as causes. ${ }^{34}$ The last two pages of the entry cover two topics: Fulvia's relationship with Antony in an attempt to explain why she was driven to hysteria in his absence and an assertion that Fulvia is not the same Fulvia from Sallust's Catalinarian conspiracy. Antony and Fulvia's marriage is recapped through citation of Plutarch's Life of Antony, 10.3-5. There are sexual undertones in the expanded description based on the "hysteria" claim. Fulvia gave Antony "severe apprenticeship of obedience" to meeting the desires of women. Antony, is described as "a brave, violent, and brutish as he was yet he found his master in Fulvia." When Antony left to be ruled by Cleopatra, Fulvia was overcome with the untapped desire to rule a man and took it out on Octavian, who made it quite clear that she was far too old a woman and far too virile in her intent. ${ }^{35}$ In terms of separating Fulvia Flacca Bambula from Sallust's Fulvia, the authors claim that had Fulvia been involved Cicero would have spoken of it. This logic is sound and still generally accepted today. ${ }^{36}$ Had Fulvia been aware of the conspiracy and involved, surely Cicero would have brought up the fact during her testimony in Milo’s trial or in the Philippics. The entry is marred by the presence of the authors' interpretation of Fulvia as a virago overcome with jealousy and lust.

\footnotetext{
${ }^{33}$ Pierre Bayle, et al. The Dictionary: Historical and Critical, 111.

${ }^{34}$ Ibid., 112. The authors discuss Martial 11.20 and decide that Fulvia had sexual hysteria; "We must boldly affirm that womanish passions engaged Fulvia in that war."

35 Pierre Bayle, et al. The Dictionary: Historical and Critical, 115.

${ }^{36}$ See Babcock and Delia.
} 
Part II: Fulvia, Octavia, and the Suffragettes

Another theme evident in shaping Fulvia as a character used by modern authors is appropriate female behavior. These authors recognize and replicate claims by Cicero, Plutarch, and Velleius in regards to Fulvia's transgressions as a matron. Fulvia is used by modern authors beginning in the sixteenth-century to explore changing trends in female behavior, relating national concepts from imperialism to women's suffrage. Discomfort with expansion of women's rights leads to authors using Fulvia as evidence for the dangers of female authority. Just as Appian and Dio sought to explain the perceived immorality of the last century of the Republic through the status of women, authors from the late seventeenth through the early twentieth centuries cite Fulvia and her alleged ambition as evidence against American and British women stepping into the public sphere.

Following Bayle's Dictionary: Historical and Critical, the next version of Fulvia to hit the presses is created by Sarah Fielding in The Lives of Cleopatra and Octavia, published by Fielding herself in $1757 .{ }^{37}$ Fielding's introduction describes her desire to explain how Cleopatra's personal avarice destroyed her country, while Octavia's dainty faithful Romanness remains a light for the world and an example for all womankind. ${ }^{38}$ Fielding writes during the Seven Years' War and uses the Roman Republic and example of the evils of foreign luxury and materialism provided by England's expanding commercial enterprise. ${ }^{39}$ Following Plutarch Fielding uses Cleopatra and Octavia to

\footnotetext{
${ }^{37}$ Sarah Fielding, The Lives of Cleopatra and Octavia, (1757; repr., NY and London: Garland Publishing, Inc., 1974.)

${ }^{38}$ Ibid., 1.

${ }^{39}$ Sara Gadeken, "Gender, Empire, and Nation in Sarah Fielding's Lives of Cleopatra and Octavia," Studies in English Literature, 1500-1900, 39.3 (Summer, 1999), 523-4.
} 
allow the reader to examine his or her own behavior in light of cultural fears of foreign effeminacy, luxury, and moral corruption. Fielding writes to praise Octavia as a virtuous model for strong and active women. Cleopatra and Fulvia are icons of feminine degeneracy caused by greed and manly ambition.

Fielding tells the story in first person, with Cleopatra recalling her life story while holding Antony's corpse. She gleefully recounts how she had manipulated him for her own pride and pleasure: "I could not love a day without inventing some new stratagem to impose on Antony; and even sometimes, when I had no sort of purpose to work out of it, but the mere pleasure of Deceit." ${ }^{40}$ Antony is portrayed as a moron and Fulvia is beastly. ${ }^{41}$ Fielding claims that Antony would rather die in Parthia than return to Italy and Fulvia. ${ }^{42}$ Fielding sets up Fulvia as a monster not only as a foil for Octavia but as a sisterin-sinister designs for Cleopatra.

I knew Fulvia's disposition was very like my own. That she was a woman of violent passions; but that ambition was dominant in her mind, and that her arts to detain Antony were almost equal to mine. I was therefore more afraid of her, than I should have been of any other woman. ${ }^{43}$

Fielding writes of Perusia as Fulvia's desperately trying to get Antony back and has Cleopatra send a spy to report on the aftermath in Athens. The result is a romantic and dramatic monologue by Fulvia:

Whence, (said she) but from Egypt are delivered all your misfortunes? You, and your Egyptian, have been the cause of them all. What part remained for me to act, incensed as I was at your neglect and your scorn, but to throw all of Italy in to confusion; in hopes, by necessity of your affairs, to force you to return? Yes, I own Antony, and I glory in it, that for love of you I have set the Western World

\footnotetext{
${ }^{40}$ Fielding, Cleopatra and Octavia, 46.

${ }^{41}$ Ibid., 50: "I was sensible that Antony was born a Dupe to women; and therefore, the woman I should have least feared would have been one whose affection to him was so sincere, that she did not desire to make a Dupe of him."

${ }^{42}$ Fielding, Cleopatra and Octavia, 49.

${ }^{43}$ Ibid., 50.
} 
ablaze; but the flame which rages there is trifling, in comparison with that which rages in, and devours, my anxious heart. ${ }^{44}$

Fulvia begs Antony to be Caesar's true heir, to take up arms against Octavian, whom they can defeat together, causing Cleopatra to fear Fulvia's "spirit," "raging passion" and pride.$^{45}$ In a letter to Antony she writes that the world mocks him as "husband to Fulvia," taunting him, "This Fulvia, who desires to keep you in nuptial chains." ${ }^{46}$ Antony responds by running to Cleopatra, leaving Fulvia to die of a broken heart, sexual neglect, and infidelity. ${ }^{47}$ After the deaths of Antony and Cleopatra, Octavia is the victor. She survives as an icon of motherhood, of wifely devotion, and of Republican patriotism.

In this same vein, A.L Fowle, in Makers of History: Cleopatra from 1906, portrays Octavia as the anti-Fulvia. Fowle brings Fulvia into the narrative to explain the need for the pact at Brundisium. Perusia is alluded to but not explained. Fowle simply states that Fulvia had been in charge on Antony's affairs in Italy but was not authorized to bring her rivalry with Octavian to war. Fulvia's death allowed Antony and Octavian to ally since it was Fulvia who had "been extremely active in opposing Octavius's designs, and in organizing plans for resisting him;" 48 Antony was innocent. Fulvia's personality is discussed to highlight the positive change in Antony's marital status in marrying Octavia. Octavia was "not at all disposed, like Fulvia, to assert and maintain her influence over others by an overbearing and violent demeanor." ${ }^{, 49}$

Reflecting discomfort with the changing status of women the Sacramento Daily

\footnotetext{
${ }^{44}$ Fielding, Cleopatra and Octavia, 59.

${ }^{45}$ Ibid., 60.

${ }^{46}$ Ibid., 65.

${ }^{47}$ Ibid., 69.

${ }^{48}$ A.L Fowle, Makers of History: Cleopatra (NY, 1906), 220.

${ }^{49}$ Ibid., 221.
} 
Record-Union reports Fulvia's actions towards Hortensia in an article titled "Women's

Rights in Rome." The author describes Hortensia's speech before the triumvirs as a gathering of Suffragettes, an early example of women demanding political representation.

From 1909, Frank W. Abbott's Society and Politics in Ancient Rome casts both Antony and Fulvia as villains and agents of chaos. Abbott brings Fulvia into the story after the death of Caesar, saying that the "turmoil and confusion" gave her strength and clarity. Fulvia has Antony forge documents and controls the populares. She gleefully pierces Cicero's tongue with her "golden needle." ${ }^{50}$ Fulvia then controls all of Italy and makes Lucius a consul. After being thwarted by Agrippa she leads her army to Greece. Abbott summarizes:

Fulvia typifies the unrest, disorder, and passion which characterized the closing years of the Republic as perfectly as Livia, the proud, self-contained, far-seeing, tactful woman whom Octavian married two years after Fulvia's death, personifies the ideals of the new regime. ${ }^{51}$

Fulvia as an evil female archetype is a regular trend. In 1911 the Chicago Daily Press ran an article claiming that women are more sadistic and cruel than men with historical anecdotes as evidence. ${ }^{52}$ Fulvia is described as a woman with popular power who "mingled cruelty with lust;" a proto-type for modern female criminals. The same year Joseph McCabe, author of The Empresses of Rome described Fulvia as "virile and

\footnotetext{
${ }^{50}$ Frank W. Abbott, Society and Politics in Ancient Rome (NY: Charles Scribner's Sons, 1909), 74-5. ${ }^{51}$ Ibid., 72.

52 "Louise Vermilya and What Famous Students of Crime Say About Cold Cruelty of Women," Chicago Daily Press, November 10, 1911. Louise Vermilya was an Italian born woman accused of poisoning people by replacing the pepper in her kitchen with arsenic. The article is written with information from Chicago police officers who are quoted saying, "We also see that women have many traits in common with children; that their moral sense 'is deficient; that "they are, revengeful, jealous, inclined to vengeances of a refined, diabolical cruelty.". . ."And women are big children. Their evil tendencies are more numerous" and more varied than men's, but generally remain latent."'”
} 
passionate." ${ }^{53}$ Fulvia commanded the loyalty of many wicked men and "small

schemers. ${ }^{, 54}$ One particular schemer McCabe is digging at is Tiberius Claudius Nero, then husband of the future empress Livia. Once again Fulvia is referenced as a secondary character in the story of another, and once again, an author uses Fulvia to degrade the main character in question. McCabe assigns Fulvia the blame for Perusia, saying she fights to release Antony from the "silken net" of Cleopatra. ${ }^{55}$ McCabe draws also believes that Martial's epigram 11.20 indicates Fulvia's sexual desire as an additional cause of war, if not for her own satisfaction, but to potentially make

Antony jealous. The author dismisses Fulvia's motives as foolhardy. Fulvia was too nasty a woman to draw another man since Antony moved on:

Some of our authorities declare that Fulvia had tried to draw Antony from the arms of Cleopatra by making love to his handsome rival, but one can only suppose that Antony would smile if her were told that his unpleasant wife- the woman who is said to have gloated over the bloody head of Cicero, and thrust her hair-pin through his tongue - was offering her heart to Octavian. ${ }^{56}$

Julius Moritzen, author of "Cleopatra Gets the Benefit of the Doubt: Was a Woman of Merit," writing in The New York Herald July 1922, relied on historian and

${ }^{53}$ Joseph McCabe, The Empresses of Rome, (NY: Henry Holt \& Co., 1911), 10.

${ }^{54}$ Ibid.

${ }^{55}$ Ibid., 11.

${ }^{56}$ Ibid., 12. McCabe references Fulvia once again comparing her actions re: beheading to those of Julia Agrippina, mother of Nero, who allegedly had a rival love interest beheaded. This is a reflection of Dio, 61 . 32.3: "Agrippina was training her son for the throne and was entrusting his education to Seneca. She was amassing untold wealth for him, overlooking no possible source of revenue, not even the most humble or despised, but paying court to everyone who was in the least degree well-to-do and murdering many for this very reason. Indeed, she even destroyed some of the foremost women out of jealousy; thus she slew Lollia Paulina because she had been the wife of Gaius and had cherished some hope of becoming Claudius' wife. As she did not recognize the woman's head when it was brought to her, she opened the mouth with her own hand and inspected the teeth, which had certain peculiarities." Agrippina is given the traditional attributes of being a "wicked matron:" she has political aspiration, acquires property, is vengeful, is sexually licentious. 
literary critic Georg Brandes for information on his topic. ${ }^{57}$ Mortizen's article seems to be an information piece on Cleopatra based on an interview with Brandes. Brandes describes both Clodia and Fulvia as victims of Cicero's enmity and as being written reflections of the men around them. Fulvia is described as a Fury and force of nature with Brandes saying, "Fulvia's features were those of a beautiful but wild goddess of vengeance." The overall tone of the piece is one of admiration and excitement. Brandes seems exuberant that ancient women wielded authority. He concedes that Fulvia was interested in attaining power, but states this was not unacceptable, because everyone in her political and social circle was also vying for the same power. Fulvia is described as an astute politician; being composed equally of "ambition to rule, jealousy and covetousness" who enjoyed having "the weaker men obey her summons." 58

Brandes, as writer and Shakespearean critic, was known for progressive ideas on race, sexuality, and the status of women. In his 1898 commentary on Shakespeare he has an entire chapter dedicated to Shakespeare's "contempt for women." Brandes writes that Shakespeare wrote women as stock characters defined by violence, corruption, weakness of moral character, and greed. He writes that Shakespeare imagines women will do anything for the right price.${ }^{59}$ Shortly after Mortizen's article is published, Arthur Weigall wrote The Life and Times of Cleopatra, Queen of Egypt. His treatment of Fulvia is not as exuberant as Brandes.' Fulvia is once again only mentioned in relation to Antony's character: he works to make her smile and laugh, and "strong-minded Fulvia"

\footnotetext{
${ }^{57}$ Julius Moritzen, "Cleopatra Gets the Benefit of the Doubt: Was a Woman of Merit," The New York Herald, July 17, 1922. The lede reads: "Georg Brandes Finds that She [Cleopatra] Was a Victim of Envious Tongues and That Apparently She Was a Woman of Great Merit."

${ }^{58}$ Ibid.

${ }^{59}$ George Brandes, William Shakespeare: A Critical Study, Vol II (London: William Heinemann, 1898), 156-8. According to Brandes, 157, it is clear that Shakespeare's works display "psychologically speaking, the depth of early-developed contempt for womankind."
} 
controls Antony's unruly desires. When Antony and Cleopatra meet at Tarsus, Antony is "a man somewhat plagued by an emancipated wife." ${ }^{00}$ There is no mention of her actions at Perusia and her death is mentioned in passing.

\section{III: Cleopatra's Rival:}

Fulvia is not only a foil for Octavia, she is also the woman overthrown by Antony for Cleopatra according to various newspaper articles published all over the United States in the late-nineteenth and early-twentieth century. For example, The Aberdeen Herald, of Aberdeen-Chehalis County, Washington, August 16, 1894 published on the front page beneath an ad for "Electric Bitters" a short excerpt titled "Cleopatra's Rival." This twoparagraph short story is about both Octavia and Fulvia and summarizes Fulvia's relationship to Antony: "It was to Fulvia that Cleopatra was obliged for teaching Antonius due submission to female authority. He had gone through such a course of discipline as made him perfectly tractable when he came into her hands." ${ }^{\prime 1}$ I have found “Cleopatra's Rival" reprinted seemingly at random through the 1920's. There is no stated reasoning behind the publication, nor an ascribed author, though some renditions are attributed to the Westminster Review. ${ }^{62}$ It seems to be an information piece and is often located on the front page among other small miscellaneous excerpts. Why publish a short

\footnotetext{
${ }^{60}$ Weigall, Antony, 239.

61 "Cleopatra's Rival," The Aberdeen Herald, Aberdeen-Chehalis County Washington, August 16, 1894. The excerpt paraphrases Plutarch: "Octavia not only maintained the dignity of her husband's house and took care of her own and Antonius' children, but also those he had by Fulvia, one of his previous wives. Of this Fulvia Plutarch slyly remarks: It was her ambition to govern those hat governed and to command the leaders of armies." This article also in The Evening dispatch, of Provo City, Utah, August 16, 1894 above an article about a dog who wears spectacles. It was syndicated in The Star of Reynoldsville, Pennsylvania, August 15, 1894. It repeats over the next ten years all over North America and Hawaii.

${ }^{62}$ The Westminster Review was a quarterly journal of all topics founded by Jeremy Bentham and John Stuart Mill. It ran from 1823-1914.
} 
information piece on the wife of Antony, Cleopatra's rival? Most likely for the same reasons Sarah Fielding used Rome as a sounding board for tensions over Britain's imperial expansion. The idea of Rome and its prominent personalities, like Julius Caesar, Mark Antony, and Cleopatra, were part of educational and popular culture. ${ }^{63}$

Though Shakespeare's Antony and Cleopatra was ever present in the United States, Julius Caesar and Mark Antony gain popularity following the Civil War. After Lincoln's assassination Caesar is linked with him, not only because of their public deaths as controversial leaders but because of Booth's cry of "Sic Semper Tyrannus." 64 From the American Revolution until the Civil War, Julius Caesar was popularly held to be a tyrant bent on the destruction of the Roman Republic; Marcus Brutus was the hero. Caesar's connection with Lincoln helps turn his image around. Caesar becomes exceedingly popular after generations of boys and girls develop affection for him because of his place in the classics-focused school system. Caesar's Gallic Wars and Shakespeare's Julius Caesar were cornerstones of Latin translation, literature, and civic development exercises. The dual image of Caesar as the destructive dictator and as a superb general, courageous soldier, friendly author guiding students through the ancient battlefield for years over the course of their elementary and secondary educations necessarily caused tension and confusion through the early 1900s. ${ }^{65}$ As American colonial interests change and expand, Caesar is viewed more positively and productions of Julius Caesar and Antony and Cleopatra become commonplace. As the play became

\footnotetext{
${ }^{63}$ Margaret Malamud, Ancient Rome and Modern America, (John Wiley \& Sons, 2007), 3-10.

${ }^{64}$ Maria Wyke, Caesar in the USA, (University of California Press, Berkeley, 2012), 1-15, 32-36.

${ }^{65} 36-40$.
} 
more widely acted out in schools Shakespeare's Caesar, Antony, and Cleopatra become the dominant versions in popular culture. ${ }^{66}$ Tales about Antony and Cleopatra bring Fulvia into the limelight.

Trends in newspaper mentions of Fulvia include being featured as "Cleopatra's Rival" and as being described as Antony's "lawfully wedded wife." Antony's playboy adventures are a common topic and within that trend there seems to be an authorial identification with Fulvia as powerless to stop her husband from leaving her for the beautiful and mesmerizing Cleopatra. Most of this type of excerpt seem to be directed towards women and are often found in "Women's Interest" sections. From the Public Ledger of Memphis Tennessee, (January 08, 1876,) an article titled "The Power of Plain Women" claims while the wily Cleopatra was breathtaking, Fulvia achieved greatness through plainness. The unnamed author asserts that though Fulvia is not described as overly beautiful, she was able to wield more authority because of it. ${ }^{67}$

There is also a travel diary theme written from the point of view of a Western prospector talking about Antony's adventurous exploits. First published as "Summary of the Career of Cleopatra" in the Washington Standard, (March 23, 1878, Olympia, Washington Territory) on the front page, the excerpt mixes history and comedy and adds contemporary references.

After the death of Julius Caesar, at Rome, his son Octavius came into power. Then Antony made a trip to Egypt, ostensibly to inspect the Suez Canal, but really to see Cleopatra, whom his late friend, the immortal Caesar was never weary of talking about. Antony reconciled his wife, Fulvia, to his departure by promising to bring her a nice obelisk on his return. Once in Alexandria and introduced to Cleopatra, Antony succumbed like the rest. He neglected all

\footnotetext{
${ }^{66}$ Wyke, Caesar, 52-6. The rise in play productions coincides with a decline in Latin language requirements.

${ }^{67}$ Public Ledger, January 8, 1876.
} 
business and surrendered himself to pleasure continually. He escorted her to theaters and balls and treated her to more champagne suppers than you could count. ${ }^{68}$

This story is repeated in format with revisions in the Caldwell Tribune, (Caldwell, Idaho Territory, July 28, 1888), but this time it is called "The History of Cleopatra." It states that "Antony reconciled Fulvia, his wife, to his departure by promising to bring her a nice mummy for a hat rack to decorate the hall. ${ }^{99}$ These pieces are absurdist humor directed towards a general audience. When these articles circulated Western papers in both states and territories were known for their satirical take on Eastern newspapers. Papers in the East were presented as moralizing influencers and cultural missionaries over new immigrant populations. Western papers mocked this mindset and reframed Eastern articles to highlight Gilded Age hypocrisy. ${ }^{70}$

Fulvia as Cleopatra's Rival continues in popular biography in Philip W. Sergeant's Cleopatra of Egypt: Antiquity's Queen of Romance. ${ }^{71}$ Sergeant, writing in 1909 , is one of the most sympathetic authors towards Fulvia's actions. He seems to favor the female Roman characters in his narrative and writes as though he baffled by their connection to Antony. Antony is written as a user who does not deserve the love or support of the women he weds. Fulvia is introduced after Antony and Cleopatra meet at Tarsus. Sergeant struggles to understand why Fulvia, Octavia, and Cleopatra would want

\footnotetext{
68 "Summary of the Career of Cleopatra" Washington Standard, Olympia, Washington Territory March 23, 1878. In terms of contemporary references for example, it claims that Caesar was cut up by the Molly Maguires. After Antony leaves for Egypt the narrative continues: "In the meantime among the Roman cubs, trouble was bruin." Antony is unhappily married to Octavia who is "several octaves too high" for him. He misses Fulvia and Cleopatra's steam ship.

69 "The History of Cleopatra," The Caldwell Tribune, Caldwell, Idaho Territory, July 28, 1888.

${ }^{70}$ Marion Tuttle Marzolf, Civilizing Voices: American Press Criticism 1880-1950 (White Plains, NY: Longman Publishing Group, 1991.

${ }^{71}$ Philip W. Sergeant, Cleopatra of Egypt: Antiquity's Queen of Romance (NY: George H. Doran Publishers, 1909).
} 
Antony at all. "Fulvia's attachment to Antony is one of the most remarkable features of his life. . [it] suggests a fascination about him which we might otherwise hardly suspect."72 Sergeant reflects on Plutarch's description of Fulvia (as desiring to command a commander) and claims that Fulvia was equally influenced by Antony during their time together. ${ }^{73}$ For Sergeant, Fulvia can be cruel and vengeful but at her core she acts from love. He claims that her actions during the proscriptions particularly the death of Cicero and the use of her hair pins, were done out of love for her father. Sergeant claims that Fulvia pierced Cicero's tongue for mocking her father's speech impediment. ${ }^{74}$

Additionally Sergeant describes the enmity between Octavian and Fulvia as arising from the disrespect he showed Clodia by divorcing her. ${ }^{75}$ Fulvia's role in the Perusine War was on account of a her love for "a man who deserved none too well of her." 76 Sergeant writes that the image of Fulvia as a true military commander trying to seize land on behalf of the Antonian faction is the product of ancient historians; Fulvia fought "untroubled by Republican scruples," to bring Antony way from his hedonistic life in Alexandria. ${ }^{77}$ When they reunite in Athens Antony is so "irate" and "violent" that Fulvia just decides to die after confronting him about Cleopatra and the pleasure boat at

\footnotetext{
${ }^{72}$ Sergeant, Cleopatra, 139. Sergeant writes very little on the historical accounts of her personality. He once calls her "Fiery Fulvia" (80), but is neutral in his descriptions of her.

${ }^{73}$ Ibid., "Fulvia, in her intercourse with Antony, however, was not merely influenced, but herself influenced him in return."

${ }^{74}$ Cic., Phil., 3.6.16. Cicero mocks Fulvia's father: "but the father of your wife, - a good woman, at all events a rich one, - a fellow of the name of Bambalio, was a man of no account at all. Nothing could be lower than he was, a fellow who got his surname as a sort of insult, derived from the hesitation of his speech and the stolidity of his understanding." Sergeant writes that avenging her father was part of her daughterly duty since it was Bambulio's influence and wealth that had given her her marriages and her children.

${ }^{75}$ Sergeant, Cleopatra, 168-9.

${ }^{76}$ Ibid., 169.

${ }^{77}$ Ibid., 152.
} 
Tarsus. ${ }^{78}$ Sergeant follows Appian's version of Fulvia's death and states that Antony should have blamed himself as if he had killed her, that Fulvia "whatever her faults, was strongly attached to him and had done much for him." Antony had been poor and out of Caesar's favor when they wed, had no sons, and had been dating a mime. Fulvia "rescued him from the clutches of Cytheris" and protected him until he was overtaken by the "still stronger power of Cleopatra." 79

Emil Ludwig, author of 1937's Cleopatra: Story of a Queen, writes that Cleopatra simply hated Fulvia because Fulvia showed regal ambition. Cleopatra and Fulvia are shown to be political rivals. Fulvia wanted to make Antony king of Rome so that she would rule as queen. ${ }^{80}$ Ludwig paraphrases Velleius Paterculus and Plutarch on Fulvia's body and character. He then expands about her actions as Cleopatra's rival. Fulvia's "restless and inventive mind had at last found the field in which she could play her dangerous game - and she played it for years until her death. Fulvia was perhaps the only Roman citizen who was a match for Cleopatra in the approaching conflict." ${ }^{81}$ Like Frank W. Abbott, Ludwig claims that Fulvia made many of Caesar's posthumous papers, alleging that Caesar's secretaries forged "dozens of papers for Fulvia" and Antony made fake senatorial resolutions on her command. ${ }^{82}$ Ludwig claims that Cleopatra suspected Antony and Fulvia of wanting Caesar's position (and participating in his assassination) and knew they were enemies (of Caesar) when she considered Fulvia's ambition. It was

\footnotetext{
${ }^{78}$ Sergeant, Cleopatra, 167. Sergeant makes sure that the reader knows Fulvia blames Antony and not Cleopatra. Fulvia and Cleopatra are described as peers in strength of character and ability. He also, in a rare reference to allegations of her personality, that if Fulvia's temperament was anything like the "Fulvia from the evidence which the classical historians have given us, the effect of the interview [with Antony] at Athens was disastrous."

${ }^{79}$ Ibid., 168.

${ }^{80}$ Emil Ludwig, Cleopatra: Story of a Queen (NY: Viking Press, 1937), 112.

${ }^{81}$ Ibid., 113, 143.

${ }^{82}$ Ibid., 145.
} 
also Fulvia's "cunning" that made Antony a triumvir. ${ }^{83}$ After the death of Caesar and division of territory, Cleopatra has Fulvia followed. Cleopatra's spies follow Fulvia and track her movements. They report her "hatred and love for power," and that Fulvia was miserable as she was forced to "play the part of while" to control Antony. ${ }^{84}$

Michael Grant in Cleopatra, (1972), follows the narrative of a political rivalry. Grant claims that Fulvia's “position as Antony’s consort was recognized by an unprecedented official tribute" (i.e. coins). ${ }^{85}$ Grant also follows the thought that Fulvia was the prototype for later empresses saying she was "a significant phenomenon: a greater political force than any Roman woman had been before, and the first wife of a Roman leader and ruler ever to play a really active part in political life." ${ }^{86}$ He claims that Fulvia controlled the West for Antony and was recognized in the East through coinage. Grant also believes that Cleopatra must have been influenced by Fulvia and adjusted her behavior to please Antony. Cleopatra must have known of Mark Antony having a "Roman wife whose forcefulness and power" were queenly and acted accordingly. ${ }^{87}$ In regard to the Perusine war, Grant claims that Fulvia fought out of jealousy, "inciting" Lucius to violence "for the initiative, apparently, was hers." ${ }^{\prime 8}$ Whether she was angry over Cleopatra or Glaphyra, Antony was furious and never spoke to her again. ${ }^{89}$

\footnotetext{
${ }^{83}$ Ludwig, Cleopatra, 147.

84 Ibid., 158.

${ }^{85}$ Michael Grant, Cleopatra, (NY: Simon \& Schuster, 1972), 114.

${ }^{86}$ Grant, Cleopatra, 114.

${ }^{87}$ Ibid., 115. This of course supposes that Fulvia would know how to behave royally in a way unknown to the Pharaoh of Egypt.

${ }^{88}$ This follows Appian, B. Civ, 5.3.19 "Then Fulvia, moved by a woman's jealousy, incited Lucius to discord."

${ }^{89}$ Grant, Cleopatra, 125.
} 


\section{IV: Fulvia, Wife of Antony}

Following Plutarch's lead, modern authors have also used Fulvia to shape and define Antony's character. For example, Henry Houssaye, writing in Cleopatra, A Study, (1890), ${ }^{90}$ does not dwell on Fulvia as a character. He instead succinctly states that Fulvia was the sole cause and actor in the Perusine War. ${ }^{91}$ He does not describe the personal character of either Fulvia or Cleopatra, only the effect each had on Antony. As for Antony, he "possessed many manly attractions. His first wife Fulvia loved him passionately; his second, Octavia, loved him supremely; the haughty Cleopatra gave him love for love." 92 Fulvia is mentioned once more as having "enslaved" Antony only to have Cleopatra "bewitch" him."93 These women only exist to enhance Antony's narrative.

Another novel that uses Fulvia to give depth to Antony is Allan Massie's Antony, (1997) a novel written from the perspective of Antony's secretary Critias after the fall of Alexandria. ${ }^{94}$ Antony is presented as a man unsure how to proceed in most situations. He is a competent warrior and personally easy-going. Critias serves as a judge of both Antony and Fulvia. He is always quick to point out that Fulvia rarely behaves appropriately as a matron or as Antony's wife. Critias claims that Antony's marriage to "terrible Fulvia" was the result of his mother Julia's strength and his father Marcus Antonius Creticus' weaknesses. ${ }^{95}$ Antony had been both Fulvia's and Clodius' lover in

\footnotetext{
${ }^{90}$ Henry Houssaye, Cleopatra, A Study (NY: Duprat \& Co., 1890). The biography of Cleopatra was originally part of Aspasie, Cléopâtre, Théodora, (Paris: Société des amis des livres, 1899.)

${ }^{91}$ Ibid., 53

92 Ibid., 58.

${ }^{93}$ Ibid., 55

${ }^{94}$ Allan Massie Antony, (Hodder and Stoughton, London, 1997). This is a new perspective on the premise of many Cleopatra novels in which she writes of her life after Antony's death.

${ }^{95}$ Ibid., Plutarch also makes this point in Vit. Ant., 1.2, 2.1-3.
} 
his youth (no mention of whether Curio was in on the action.) They continue to influence him in his adulthood. Critias discusses Clodius as a demagogue and popularis but does not mention Fulvia's role in his life. ${ }^{96}$ As for her personality, Critias exclaims, "Everyone knows that Fulvia had a tongue like a viper's kiss." ${ }^{\text {97 }}$ Fulvia was the core cause of Antony's and Cicero's feud. She was beautiful but unlovable. Antony would curse her and then submit and apologize when confronted. He needed her because "she had a keener grasp of the political situation than most men." ${ }^{98}$ Some of the novel is written in epistolary form with Fulvia critiquing Antony from afar. She puts Antony's faults in a letter with specially outlined solutions. Fulvia also tries to shame him into action: "Be the man you are capable of being. It was he whom I chose to marry, prove to me that you are worthy of me." Critias hates her but appreciates the abuse she serves Antony: "Really, bitch and virago though she was, you couldn't help admiring the woman." 99

Massie writes Fulvia as an active politician and historian, to Antony's detriment. Fulvia writes an account of creation of the triumvirate. After the triumvirs divide Roman territory Fulvia writes Antony again saying that Octavian has fooled him into giving up Italy. She then accuses Antony of having no respect for her noble family since he won't force Octavian to formalize marriage with Clodia. Antony is more concerned that Lucius, as consul, will not be able to resist any demands Fulvia makes. Massie's treatment of the Perusian War is short. Fulvia is not cause, she merely supported Antony's rioting soldiers after Octavian took the best farmland. She also saw it as an opportunity to break up the

\footnotetext{
${ }^{96}$ Massie, Antony, 11, 12-3.

${ }^{97}$ Ibid., 14.

${ }^{98}$ Ibid., 28.

${ }^{99}$ Ibid., 30.
} 
triumvirate for Antony so that he would not have to discredit his word. ${ }^{100}$ During the war Fulvia ran the garrison, punished the faint of heart, and even hanged people who wanted surrender (though Antony doesn't believe this.) Lucius betrays her and surrenders so he can receive pardon. and it pardoned. Fulvia is taken care of by Vestal Virgins until Antony takes custody of her and has her shipped to Athens. She dies pitifully as only “one so enraged against the world" can. ${ }^{101}$ Antony mourns her:

I left her in Athens. I was not sorry to do so, for her reproaches were intolerable. But I grieved when she died a few months later. For all her faults and anger, she was the only one of my wives who allied herself wholeheartedly to my cause; and if she harmed it, as she did, it was not through malice. ${ }^{102}$

Critias, however, berates Fulvia as a "virago" and says he doesn't blame Antony for any of his infidelities. He mocks Antony for feeling guilty. Critias eventually concedes that he can understand why Antony weeps: "He knew perfectly well she was a horror, but she was his horror." 103 Antony continues to miss Fulvia even in Alexandria. Critias is not fond of Cleopatra and feels that she makes Antony weak through indulgence; she is also not as beautiful or funny as Fulvia, though she is more charming. ${ }^{104}$ Before Antony's death he states he misses "that bitch Fulvia." 105

The novel Memoirs of Cleopatra by Margaret George was also published in 1997 and follows Cleopatra as she records her life story in preparation for her suicide. Fulvia is a much-admired woman and positive force on Antony. She introduces herself to Cleopatra at a party thrown by Caesar. Cleopatra finds Fulvia to be a kindred spirit in

\footnotetext{
${ }^{100}$ Massie, Antony, 65-7.

101 Ibid, 69-71.

102 Ibid., 72.

103 Ibid., 73.

104 Ibid., 75.

105 Ibid., 86.
} 
competing in traditionally male spheres of action. Fulvia is described as having a commanding bearing "like an Amazon." ${ }^{106}$ Cleopatra says she had heard of Fulvia "in connection with street fights in Rome." Though Fulvia is at the party looking for a husband, Cleopatra thinks she is fine without a man, because the man who could match her "would have to be Hercules." 107 This of course, is where Antony comes in, dressed as Hercules with Cytheris. Fulvia pulls him away to speak with him and they are soon wed. Unlike McCullough's cruel characters discussed below, George's characters are inherently good, though they are complex and sometimes make poor decisions or act cruelly. This may be due to the nature of the master narrative framework. Cleopatra is looking sadly back on her life and the people she has loved and lost. The work, though bright and warm in emotion, does carry a shadow of tragic sadness. George's Antony is a fictional version that Arthur Weigall would have loved. Antony is a great lovable bear of man, foolhardy and full of mirth. He does need guidance in the day to day doldrums of politics but is decisive and useful in times of crisis. ${ }^{108}$ Fulvia is Antony's partner and he regularly jokes about needing to sneak away to meet with Caesar during Fulvia's pregnancies because she would "insist on coming," or else have "barred" Antony from going. George's Antony revels in being "tamed" and enjoys pleasing women and being associated with them in contrast to McCullough's version of Antony who is quickly angered over teasing about his domestic status and violently brings it up during his irrational outbursts. ${ }^{109}$

\footnotetext{
${ }^{106}$ Margaret George, The Memoirs of Cleopatra, (NY: Martins' St. Griffin, 1997), 227.

${ }^{107}$ Ibid., 272.

${ }^{108}$ Ibid., 273-80.

${ }^{109}$ Ibid., 333.
} 
Fulvia is a key presence in Rome and works with Caesar and with Antony to control Rome after Caesar's death. After Cleopatra leaves Rome she does not think of Fulvia again until confronted by Antony at Tarsus over her lack of support for hunting Caesar's assassins. In a reversal of narrative tradition, Cleopatra proudly thinks of Antony as "Fulvia's husband," not in spite or competition, but in acknowledgment that he is good enough for the woman Cleopatra admires. ${ }^{110}$ However, there is little mention of Fulvia until Perusia. Cleopatra initially urges Antony to act against Octavian and help Fulvia but he is wary to breach his word. As more news comes to Alexandria, Cleopatra is angry at Fulvia for jeopardizing Antony's status in Rome. She urges him to divorce and Antony defends Fulvia, her loyalty, and their marriage. ${ }^{111}$ Cleopatra receives word that Antony took too long in organizing his forces to invade Italy and was faced with an uprising of Parthians to contend with first. Fulvia was near death when they were reunited. When Antony finally comes back to Alexandria a few years later, he does not speak of her death to Cleopatra. She only ever berates him over Octavia. ${ }^{112}$ Fulvia remains a presence in their marriage for the rest of the novel not only through her place in Antony's heart but through Curio and Antyllus when they come to live in the palace as part of Cleopatra's family.

The character of Fulvia is used to great negative effect in Collen McCullough's "Masters of Rome" Series, including Caesar's Women, The October Horse, and Antony and Cleopatra: A Novel. ${ }^{113}$ Fulvia is introduced in Caesar's Women as a young aristocrat

\footnotetext{
110 George, Memoirs, 452.

111 Ibid., 483-7.

112 Ibid., 504-5, 525-7.

113 Colleen McCullough, Caesar's Women, (NY: William Morrow \& Co., 1996); The October Horse, (NY: Simon \& Schuster 2002; Antony and Cleopatra: A Novel, (NY: Simon \& Schuster, 2007
} 
trying to turn her husband Clodius into a demagogue. She is often referred to as the granddaughter of Gaius Gracchus because this is where her family and friends believe her desire for popular politics stems from. ${ }^{114}$ In The October Horse Antony and Fulvia wed. Antony is stupid and cruel. McCullough describes him as lacking "most a sense of morality, of ethical behavior, of respect for life and human beings" and as "feral and avaricious, priapic and impulsive." ${ }^{115}$ Antony beats every woman he comes in contact with in this series; they jump and flinch in conversation with him. Fulvia is nearly a male version of Antony; they differ in ambition. Following Cicero's model, Fulvia's ambition drives her to cruelty. Antony and Fulvia actively plot to assassinate Caesar. ${ }^{116}$ McCullough's Cicero and Fulvia have a personal hatred for one another over Clodius. This Fulvia only truly loves Clodius, Antony is merely the mostly likely Roman to seize power in a fashion acceptable to her. Fulvia revels in the proscriptions and skewers Cicero's tongue with a steel stylus used for writing. She then quips ("with huge satisfaction"), "That's what I think of his gift of the gab." ${ }^{117}$ Both Antony and Fulvia are callous parents. Antony is insecure over the status of his powerful wife and Fulvia keeps him in check through withholding her money. Their marriage ends in extreme violence after Fulvia's failure in the Perusine Wars. McCullough does not treat the wars with depth, only the aftermath. Antony and Fulvia are reunited in the beginning of Antony and Cleopatra: A Novel. Antony physically and verbally brutalizes Fulvia for four pages. He knocks out her teeth and breaks her nose. He rips out chunks of her hair and kicks her repeatedly. He throws her out of his house in Athens after serving her divorce papers and

\footnotetext{
${ }^{114}$ Colleen McCullough, Caesar's Women, 369-403; The October Horse, 238.

${ }^{115}$ McCullough, The October Horse, 237.

${ }^{116}$ Ibid., 468-92.

${ }^{117}$ Ibid., 648.
} 
forbidding her from seeing their children. Fulvia, "her heart broken beyond mending," slits her wrists. ${ }^{118}$ The blind rage and brutality Antony exhibited towards Fulvia reveal his unstable character in times of crisis. It serves to explain his underestimation of Octavian and eventual downfall.

Modern biographers of Cleopatra also write Fulvia as they see fit to bolster Antony or Cleopatra. Stacy Schiff in Cleopatra: A Life (2011) writes Fulvia as springboard for Cleopatra, as a Cassandra-type figure tragically ignored, and as the victim of Cicero. ${ }^{119}$ The idea of Fulvia as setting the stage for Cleopatra is, of course, drawn directly from Plutarch's Life of Antony 10.3-4. Schiff also follows Cicero's theme of assessing the women in Antony's life to reveal his true character. Fulvia is introduced during Schiff's discussion of the Philippics and used as evidence that Antony loves her (and women in general) more than he loves Rome. Schiff lists the crimes Cicero lays at Fulvia's feet: decimation, confiscation of property, selling Rome's property, operating a brothel, etc. ${ }^{120}$ Fulvia is next part of the proscriptions, which are curiously graphically detailed. Schiff claims that Cicero's head was cut off with "inexpert hacking" and that it required some strength for Fulvia to pry open his mouth and gauge out his tongue. ${ }^{121}$ Later in the book Fulvia is more fleshed out as a character, not "one to stay at home and spin wool," she is as "wealthy, connected, shrewd and courageous, as she was beautiful." ${ }^{122}$ Schiff does not treat Perusia with detail, only the aftermath. Fulvia is abandoned for Octavian, though Fulvia had "forcefully argued" and warned Antony

\footnotetext{
${ }^{118}$ McCullough, The October Horse, 71-4, 98.

${ }^{119}$ Stacy Schiff, Cleopatra: A Life, (NY: Back Bay Books, 2011)

${ }^{120}$ Ibid., 151-2.

${ }^{121}$ Ibid., 153. Fulvia is described as doing this for "her own reasons."

${ }^{122}$ Ibid., 164.
} 
about the danger Octavian posed to him. ${ }^{123}$ Schiff's Fulvia is a loosely interpreted version drawn directly from Plutarch and Cicero without direct attribution to the sources.

\section{V: The Death of Cicero}

Fulvia's alleged activities during the proscriptions helped Appian and Dio write on the chaos they felt the late Republic embodied. Though Dio is the only source that claims Fulvia demanded Cicero's head, the image of Fulvia stabbing Cicero's tongue is an enduring one. It is gory, graphic, and attention grabbing. Violence, like sex, sells. And so the most enduring popular image of Fulvia in text is the death of Cicero. The scene is recounted to describe the depravity of political purges, as evidence of the corruptive nature of female power, or in modern trends, to demonstrate Fulvia's political and personal power. She wielded enough authority to demand the head of Rome's greatest orator. For modern audiences Fulvia's tale is also one of retribution, a quest for vengeance against Cicero.

Early newspaper featurettes follow a number of themes surrounding the death of Cicero. For example, an epic poem in the style of Tennyson published in the Gold Leaf of Henderson, North Carolina, (1893), proclaims that Antony should have died with Fulvia. It is unclear in the poem if the author thinks that Antony should have died in Sicyon or Fulvia in Alexandria, either way, the poet wishes they were both run through by the same dagger. ${ }^{124}$ Why? For treason against Rome and one of her core patriots, Cicero. Similarly, the Bridgeport Evening Farmer, of Bridgeport Connecticut, in a page spread

\footnotetext{
${ }^{123}$ Schiff, Cleopatra, 174-7, also 183, 252. Even at Actium Fulvia is just off stage. Antony and Cleopatra consider the warnings Fulvia had given them. Cleopatra considers Fulvia's fate and the ridicule of her legacy when deciding whether or not to lead her soldiers at Actium.

${ }^{124}$ The Gold Leaf, May 25, 1893.
} 
titled "Women and the Home" features Fulvia as a person of interest in Cicero's death. It claims that Antony met his match in Fulvia who was as "violent and bold" as he was.

She participated with in various massacres and had several persons put to death on her authority. She was responsible for the beheading of Cicero, whose head she caused to.be brought to her, spat upon it, drew out the tongue, which she pierced several times with her bodkin and addressed to the life less head of Cicero the most opprobrious language.

This article echoes a feature about famous beheadings throughout history published in the National Tribune, Washington, D.C. from $1894 .^{125}$

Ernle Bradford in Cleopatra (1972), only includes Fulvia in relation to the proscriptions and Perusia. ${ }^{126}$ With no hesitation in casting judgment, Bradford writes, “The odious Fulvia even stuck a pin through Cicero's tongue, because it had spoken against her husband. Rome in those days was great only because of its power; in other aspects it was vile." 127 He is decidedly pro-Octavian and calls Perusia a revolt by Fulvia against Octavian's authority. He does not go to length to reveal Fulvia's personality, simply calling her "strong minded" and fond of lecturing Antony. In this narrative Fulvia is clearly a virago drawn from Appian, Dio, and Shakespeare. She only exists to confound the works of men: she kills Cicero, she tries to stop Octavian, and she berates Antony. Her death allows the men to get back to business.

Cicero's death and the proscriptions are also heavily featured in Diana Preston's Cleopatra and Antony: Power, Love, and Politics, in the Ancient World. ${ }^{128}$ Preston builds on Fulvia as described by Cicero and Plutarch. Preston's assessment of Fulvia's motives

\footnotetext{
125 The Bridgeport Evening Farmer, September 5, 1917.

${ }^{126}$ Ernle Bradford, Cleopatra, (NY: Harcourt 1972).

${ }^{127}$ Bradford, Cleopatra, 137.

${ }^{128}$ Diana Preston, Cleopatra and Antony: Power, Love, and Politics, in the Ancient World (NY: Walker \& Co. 2009).
} 
is defined by her understanding of Fulvia as the woman who killed Cicero. Fulvia is ambitious, manipulative, and the kind of woman to shed blood. Preston introduces Fulvia with Plutarch's Life of Antony 10.3-4 and then notes that "Antony seemed to Fulvia a suitable—and — malleable replacement [for Curio]. ${ }^{129}$ Preston paints Antony is indecisive and often receiving help from "politically attuned Fulvia." ${ }^{130}$ Fulvia is recognized as a victim of the Philippics, ${ }^{131}$ but then described as standing "so close. . . [to the action at Brundisium]that blood spattered on her face." ${ }^{" 132}$ Description of the proscriptions is limited to Fulvia's vengeance upon Cicero. Preston writes that "Fulvia, wife to Clodius as well as Antony and with a double dose of vengeance to extract, apparently spat in his blood-smeared face, and, yanking out his once valuable tongue, impaled it with a hair pin." ${ }^{\prime 33}$ She also references these actions in considering Fulvia's actions at Perusia, particularly Fulvia's reaction to Octavian's rejection of Clodia. Preston states that Octavian divorcing Clodia, "was a terrible insult and one that a woman such as Fulvia, who had used Cicero's tongue as a pincushion, was unlikely to forgive." 134 Preston doubts emotional connection between Fulvia and Antony. She states that if Antony did ever depend on Fulvia politically he had no use for her after he became Eastern imperator. Preston claims that if Antony had been so dependent on Fulvia for political advice and encouragement he would not have left her in the west. Preston writes

\footnotetext{
${ }^{129}$ Preston, Cleopatra and Antony, 102. Additionally, Fulvia is so ambitious (in reference to "commanding a commander") that in not only did Fulvia controlled Antony's behavior, she "encouraged him to be more single minded in his pursuit of power."

130 Ibid., 122.

${ }^{131}$ Ibid., 135.

${ }^{132}$ Ibid., 136. This is drawn from Philippics 3.2 Antony's "wife's face was notoriously besprinkled with the blood of men dying at his and her feet."

133 Preston, Cleopatra and Antony, 146.

${ }^{134}$ Ibid., 173-4., 176. In addition to retribution, Preston also believes Appian's narrative of jealousy as a motive. She writes that Fulvia is definitely jealous of Glaphyra and Cleopatra. Antony in Alexandria, ignoring her messages "would have been deeply aggravating to a woman of her temperament."
} 
of Antony as free and in control without Fulvia: "The New Dionysus. . felt no need of a bossy, middle-aged Roman matron at his side, however astute she was." ${ }^{135}$

The most extreme representation of Fulvia in connection to the death of Cicero comes from the only work that features Fulvia as the main character, Fulvia or Hercules and the Creature. ${ }^{136}$ Given that Fulvia is star, you may think that 'the creature' would be Octavian, but it is not. It is Fulvia! Author Barry Taylor's screenplay-style novel follows Fulvia in a fevered quest to destroy Cicero and to feed off of the power gained through breaking men's spirits. Taylor uses not only every ancient stereotype about women he could find but also uses modern literary tropes and a profound number of anachronistic elements. Fulvia is introduced by Antony, who had been sitting around thinking about his wife's mother, Sempronia, who ate men for every meal of the day. Antony calls Fulvia her mother's daughter and "ferocity personified." 137 The ferocity Antony references is Fulvia's divorce rate; she has already divorced Clodius, Curio, someone named Scribio and several others Antony cannot remember. Fulvia spends most days drinking and doing drugs (commonly referred to here as "lunatic potion") and plotting the death of Cicero. ${ }^{138}$ Fulvia also rules Rome and the outlying countryside with a band of thugs, marauders, and gladiators who are helping her rebuild "a Catalinic vision of the past." 139

Fulvia constantly has mental breaks that focus on Cataline. It is not clear whether he is her master, or father, or abuser. Fulvia patrols the city in a carriage that she drives

\footnotetext{
${ }^{135}$ Preston, Cleopatra and Antony, 182. Preston spends a good deal of ink comparing Octavia to Fulvia and Cleopatra.

Octavia has "none of the unwomanly stridency and personal ambition of Fulvia." Additionally on page 227 , she describes Octavia as "the antithesis of the martial, managing Fulvia."

${ }^{136}$ Barry Taylor, Fulvia or Hercules and the Creature, (Essex: Maypole Editions, 1990).

${ }^{137}$ Taylor, Fulvia, 16. Fulvia's mother Sempronia here is also the Sempronia from Sallust's Cataline.

${ }^{138}$ Ibid., 17.

${ }^{139}$ Ibid., 20.
} 
too fast and recklessly from meeting to meeting with city bosses to discuss her proposed legislation. Fulvia wrote Cataline's bill to eliminate debt and wrote the bill that exiled Cicero. ${ }^{140}$ Fulvia's madness seems to stem from some sort of trauma connected to Cataline, who may be her incestuous father, whom she killed with a stiletto. ${ }^{141}$ Fulvia's only joy comes from bloodshed: her cruelty knows "no bounds," especially in regards to controlling Antony. Fulvia hates Antony because she loves him and love is a weakness. She tries to drive him away with her ferocity. At Brundisium Fulvia kills all of Antony's revolting soldiers, some with a cudgel, some she whips to death, others she forces to run until they die. ${ }^{142}$ Fulvia is disgusted by Antony's leniency and tries to further separate herself from him by having an affair with his brother Lucius. During this time, Fulvia is becoming increasingly unstable and has flashbacks of incest, arson, murder, and infanticide. It is alluded to that she may have given birth from the incestuous attacks and threw the baby in the kitchen fire. ${ }^{143}$ If that were not enough to derail her thoughts on political scheming, her mind constantly turns to Antony, "the embodiment of lust" who keeps her from reaching her true potential. She spends a great deal of time and energy thinking about the fine qualities of his penis. This eventually drives her to finally murder Cicero. ${ }^{144}$

Fulvia sneaks into Cicero's villa and kills him with her stiletto. She beheads him, cuts his tongue out and keeps it in a jar of formaldehyde. She jumps into her sports carriage and races off to Sempronia with the tongue. Why? Because Sempronia is a

\footnotetext{
140 Taylor, Fulvia, 30-39.

${ }^{141}$ Ibid., 40-46.

142 Ibid., 48.

${ }^{143}$ Ibid., 77-9.

${ }^{144}$ Ibid., 88-9.
} 
witch! And they are going to use Cicero's tongue to divine the future using magic and a Greek Ouija board. Fulvia wants to know if Antony will be king of Rome. Apparently because Fulvia is a witch her lust/love for Antony clouds her powers and unless he can be powerful on his own, he will keep making her crazy. ${ }^{145}$

The story then shifts to several chapters of Antony and Octavian fighting at Philippi. While they were away Fulvia had initiated the Vestal Virgins and Servilia, Brutus' mother into her coven. There is a great deal of satanic imagery in Fulvia's fight at Perusia. Fire and brimstone and golden satanic runes sewn into her black dress. Fulvia's army ravages Italy until Agrippa and Octavian convince Antony to sacrifice himself to the hell-beast for the good of Rome. Antony meets with Fulvia and serves her divorce papers. When she is distracted a priest ensnares and kills her. ${ }^{146}$ But, little did Antony know that this was all part of her plot. Fulvia actually sent her consciousness in a letter to Cleopatra (also part of the coven and Fulvia's former lover). When the letter is opened Fulvia possess Cleopatra and waits for Antony to arrive. ${ }^{147}$ The end.

Extreme absurdist fiction seems a likely place to find a fevered revenge plot against Cicero but the theme also resonates in academic discussions of Fulvia. In Women in World History: v. 1: Readings from Prehistory to 1500 by Sarah Shaver Hughes and Brady Hughes (Routledge, 1995), the entry for "Fulvia" describes her as ambitious, and states she "suddenly becomes powerful, sparing the riches of a man who helped her (presumably Atticus, though he is not named) and arranging the decapitation of one who

\footnotetext{
145 Taylor, Fulvia, 100-02.

${ }^{146}$ Ibid., 161,186-92.

${ }^{147}$ Ibid., 229-41
} 
had refused to sell her a coveted villa." ${ }^{148}$ Fulvia is further described as "Clodius" widow" who "mutilated" Cicero's head by "cutting the tongue before Antony displayed the mutilated head to the senate."149

Spinning the same concept into a locus of gender and gendered rage, historian Mary Beard often describes Fulvia's use of Cicero's head as an example of a particularly female instance of revenge. In Confronting the Classics Beard describes Fulvia's actions as "beyond . . routine sadism," claiming she exacted "woman's vengeance.” Beard credits Fulvia's use of her hairpin as the feature that has given this scene mythic status: "In rending his tongue with her hair pin, she was attacking the very faculty that defined men's role in the political process, and Cicero's power in particular. At the same time, she was transforming an innocent object of female adornment into a devastating weapon." 150 Beard's concept of the hairpin as a symbol of woman's retribution has gained a popular following and inspired a feminist news site The Hairpin.com.

Fulvia is not the only ancient literary woman to have used female-coded items as weapons and not the only woman to use those weapons on the severed head of an enemy. Alcmene, mother of Herakles, gauged out the eyes of Eurystheus with her knitting needles. Eurystheus had been proclaimed as Zeus' legitimate son instead of Hercules and the two had a lifelong enmity. Apollodorus recounts the event:

When Hercules had been translated to the gods, his sons fled from Eurystheus and came to Ceyx. But when Eurystheus demanded their surrender and threatened

\footnotetext{
${ }^{148}$ Sarah Shaver Hughes and Brady Hughes Women in World History: v. 1: Readings from Prehistory to 1500 (Routledge, 1995), 117.

149 Ibid., 118. Yes, "mutilated" twice in one sentence!

${ }^{150}$ Mary Beard, Confronting the Classics: Traditions, Adventures and Innovations, (NY: Liveright Publishing, 2013, ) 80. Beard draws on this theme again in "The Public Voice of Women," London Review of Books, 36.6 (Mar. 2014): 11-14.
} 
war, they were afraid, and, quitting Trachis, fled through Greece. Being pursued, they came to Athens, and sitting down on the altar of Mercy, claimed protection. Refusing to surrender them, the Athenians bore the brunt of war with Eurystheus, and slew his sons, Alexander, Iphimedon, Eurybius, Mentor and Perimedes. Eurystheus himself fled in a chariot, but was pursued and slain by Hyllus just as he was driving past the Scironian cliffs; and Hyllus cut off his head and gave it to Alcmene; and she dug out his eyes with weaving-pins. ${ }^{151}$

This scene is present in the works of Hesiod, Plutarch, Ovid, and Pausanias. ${ }^{152}$ It is fitting that Fulvia would be connected the actions of the mother of Hercules given Antony's family affiliation to the demi-god.

\section{VI: The Dangers of Pointillism:}

As discussed in Chapter 3, the desire to recover women in classical history and reconstruct their lives and mentalite required the adoption of theoretical practice and methodologies from outside of the traditional discipline. Since the "founding" of classical women's studies with the 1973 publication of The Arethusa Papers generations of scholars have turned their focus on women in the ancient world, creating multiple schools of thought each with their own standards of scholastic rigor. This section will outline a brief historiography of formative texts on Greek and Roman women whose focus and application of theory significantly affected the genre's discourse. Efforts to find and vindicate Greek and Roman women required the development of specialized standards and methods that continue to shape the study of women in antiquity. One defining feature is the use of pointillism or specialization in attempt to establish ground work for the field. Many people work on independent topics with the hope that their contribution to their

\footnotetext{
${ }^{151}$ Apollod., 2.8.1; Plut., Thes., 13.

152 Plut., Thes., 13; Ov., Met., 9.273; Paus., 5, 9. Hes., Sh., 1.
} 
specialization may eventually be synthesized. This trend remains active but synthesis is at a minimum. This of course effects how Fulvia is represented in new works.

The Fulvia explained to be a historical character because of the layers of rhetoric, invective, and gender norms as rarely been found or understood by the majority of authors writing on Fulvia. Most diligently refer to the primary sources: Plutarch, Cicero, Appian, and Dio. Some authors read secondary texts. Most cite Babcock and Hallett's Perusine Glandes but read no further. Relying on primary sources alone creates a false character. Additionally, relying on secondary sources uncritical of primary sources creates a similar result. Uncritical assessment of Fulvia can be found in seemingly benign places like a critical commentary on Cicero. Albert C. Clark, in his 1895 commentary on Cicero's Pro Milone, mentions Fulvia only briefly. Clark's commentary is the standard textual criticism for this trial. Clark dismisses Fulvia's actions at trial and at Clodius' funeral as representative of mental instability. He references Cicero's claim that Fulvia's maternal grandfather had been described as insane saying it "may throw light upon the excitable disposition of Fulvia." ${ }^{153}$ Fortunately, despite the continued presence of the cruel Ciceronian Fulvia and the Shakespearean harpy, there are authors whose understanding comes from Delia and Pomeroy and reflects understanding of contemporary textual criticism directed towards Fulvia's sources. The specialist nature of women's history, particularly that of women in the ancient world, has led to slow transmission of new ideas and methodologies into the mainstream historical discourse, but changes are happening.

\footnotetext{
${ }^{153}$ Albert C. Clark, Cicero, Pro T. Annio Milone. Ad Iudices Oratio. (Amsterdam: A. M. Hakkert, 1895), xxvii.
} 
For example in the narrative of Cleopatra, historian Diana E.E. Kleiner shines a spotlight on Fulvia as a proto-type of early imperial women in 2005's Cleopatra and Rome. ${ }^{154}$ She dedicates three pages to a segment "Fulvia: Possible Pioneer" in which she lays out evidence of Fulvia's imperium: public visibility, portrait coins, and working with Antony's client network. Kleiner is not the first to argue that Fulvia set a behavioral precedent for Octavia and Livia, ${ }^{155}$ Balsdon called Fulvia "l'imperatrice manquée," the missed empress, and claimed that she ruled as empress in all but title.

Changes are also happening in popular histories. Phyllis G. Jestice, author of "Fulvia" in Women and War: A Historical Encyclopedia from Antiquity to the Present, describes Fulvia as a front-line military commander given an "unofficial lieutenancy" as Antony's "most important agent in Italy." 156 Though some of these ideas are speculative, Jestice acknowledges that speculation is necessary because of the polemical nature of the sources towards Fulvia and the societal context in which they were created. She writes of Fulvia's relationship with Cicero as an example of "how much the Romans hated the notion of being commanded by a woman, or female public involvement in political affairs." ${ }^{157}$ To date the most balanced account of Fulvia I have found comes from Joyce E. Salisbury writing in the Encyclopedia of Women in the Ancient World. Fulvia's life is told through "facts" drawn from the anecdotes about her life (her marital connections,

\footnotetext{
${ }^{154}$ Diana E.E. Kleiner, Cleopatra and Rome, (Cambridge: Harvard University Press, 2005), 103. Kleiner also treats Fulvia as being a proto-type for Cleopatra in Antony's life - not in the sense that Plutarch makes the connection. Kleiner writes that Cleopatra may have been drawn to Antony as an ally and husband because he was the type of man to put his wife on coinage. Page 103: On Cleopatra being Antony's type of woman, "some of his Roman women were quite formidable, especially his wife, Fulvia."

${ }^{155}$ Kleiner, Cleopatra and Rome, 232-5.

${ }^{156}$ Phyllis G. Jestice "Fulvia" in Women and War: A Historical Encyclopedia from Antiquity to the Present, Volume 2, Bernard Cook Ed. (Santa Barbara: ABC-Clio, 2006), 213.

${ }^{157}$ Ibid., 212. It is worth noting that Jestice specified "public" involvement politics as taboo, inferring the acceptability of private women's networking.
} 
children, elements of participation) in neutral language. There are no mentions of her alleged personality until a discussion about the destruction of Fulvia's image by propaganda and Roman gender norms. Salisbury includes refence and citation to modern studies. ${ }^{158}$

Conclusion:

And so, this chapter has shown that Fulvia as a character is what you make of her. She has been written and re-written as the needs of the author and the context in which the author writes, changes. Fulvia has been an early empress, a proto-type suffragette, a corporate wife, a witch, the cause of many men losing their way including Antony, Tiberius Claudius Nero, and Lucius Antony. She has ever been the cause of Cicero's death to authors but their sympathy towards her actions varies from understanding and even praise, to damnation and disgust. This chapter has shown the many ways in which Fulvia has been written over time. The concluding chapter will condense the interpretations of Fulvia research provided thus far, give the current state of understanding of Fulvia as a historical character, and outline research ideas for continued study.

${ }^{158}$ Joyce E. Salisbury, Encyclopedia of Women in the Ancient World, (ABC-Clio, 2001), 128-9. 


\section{CONCLUSIONS}

\section{FULVIA: A LIFE IN THE POSTMODERN WORLD}

Fulvia Flacca Bambula was a woman who lived and died during the late Roman Republic. She has been judged by authors of the Republic based on contemporary sociopolitical and gender norms. She had parents, Sempronia Tuditani and Marcus Fulvius Flaccus Bambulio. She has been judged based on her parents' political standing, linage, and wealth. Fulvia was married to Publius Clodius Pulcher, Gaius Scribonius Curio, and Marcus Antonius. She has been condemned by ancient authors because of these connections. And so, political propaganda is at the heart of Fulvia's negative characterization but it is one of many elements used to bury the real woman.

Fulvia's connection to men defines how she has been described. Her marriage to Clodius shapes her image. The hatred bred between Clodius' faction and Marcus Cicero builds and finally erupts during the invective Philippics. Fulvia's tie to Antony not only mars her reputation during her lifetime, his damnation during the Imperial period makes their lives and legacies targets of popular authors, each with his own intent. Cicero's shade hovers over every text with Antony's name upon it. Cicero's death has made the triumviral proscriptions into a mythic martyrdom. Fulvia cannot escape being repeatedly written as a women with loose hair and bloodied hands, satisfied by a severed head. Plutarch's moral Lives present Antony as a failed man: shameless and subservient to the will of women. By Plutarch's judgment Fulvia created that man. Monarchists both, 
Appian and Dio wrote wistfully of the bygone beginning of the Empire. Dio was so intent on presenting anecdotal vignettes that he had no time for truth.

Fulvia's image was crafted to be the antithesis of the ideal Roman matron; a role whose defining characteristic was submission. She is written as a woman dominant rather than dominated as a metaphor for the unbridled chaos by which later Roman historians viewed the reign of Antony. By doing so authors could simultaneously explain the drastic political and moral changes imposed by the Augustan regime as well as the damnation of Antony. Employing the tools made available by rhetorical training, Cicero used Fulvia to undermine Antony. Wielding themes from elegy, popular pantomime, and tragic myth Plutarch and Appian further embellished and colored Cicero's anecdotes to the same end. Dio infused the same tales with additional graphic detail and added new scenes including the afterlife of Cicero's head. Fulvia the virago was born.

Shakespeare's influence on early modern cultural interpretations of Rome and Roman people as a characters dominates perception of Fulvia in both popular and academic writing. In Cleopatra: A Life Schiff implies Fulvia was Shakespeare's kind of virago: a warrior woman, yes, but more importantly, a shrill-tongued shrew. On Fulvia's shortcomings Schiff writes that Cleopatra knew how to truly manipulate Antony. She "could have offered Fulvia a very valuable tutorial," as "she did not raise her voice," in berating Antony, ever. ${ }^{1}$ Fulvia's harping, bitching nature drove her to war and drove Antony straight to Cleopatra. This image has been repeated many times. A review of Balsdon's Roman Women describes Fulvia as “an Amazon, a good wife to Clodius, Curio

\footnotetext{
${ }^{1}$ Schiff, Cleopatra, 212.
} 
and Mark Antony in succession, infinitely loyal, a virago only in her last four years..."2 Despite the lack of evidence for this characterization of her personality, authors and scholars write Fulvia to suit their narratives or validate points of view. Delia writes that "Cicero and Octavian understood that truth is powerless in the face of myth." 3 This has been proven repeatedly; all authors writing on Fulvia have been referencing the same five primary sources but generating vastly different interpretations of the same woman.

Does this mean that Fulvia is lost? That she is a non-referential name with no existence out of textual context? No. Not only is Fulvia a woman with a material presence found in coinage and archeological evidence from Perusia, her literary presence as a historical character is not a lost cause. Significant research on Fulvia in the historiographies of Cicero and Augustus would greatly contribute to the understanding of Fulvia as a cultural creation. Additionally, a literary survey of Roman and Greek women as arbiters of revenge may offer more insight into aspects of Fulvia's written character. The historical Fulvia is like a woman who exists on the light spectrum in shades not visible to the naked eye. She can be viewed through a prism but the image is distorted. By shifting the prism, the more facets of her presence can be analyzed. The true image of Fulvia may never be revealed but work can be done to make the image clearer and more defined. Assessment of all aspects of the contextual conditions that converged to create Fulvia as a written woman, elements of literature, theater, myth, any and all components of Roman life and that be assessed, reveal new facets of Fulvia's presence. Fulvia becomes more real. She becomes more representative of the woman who lived and died

\footnotetext{
${ }^{2}$ W. K. Lacey, Reviewed Work: Roman Women by J. P. V. D. Balsdon, The Classical Review, 14. 1 (Mar., 1964), 87.

${ }^{3}$ Delia, "Fulvia Reconsidered," 206.
} 
in Rome so long ago. 


\section{REFERENCES}

Classical Texts are Loeb Classical Editions unless specified below.

Appian. The Civil Wars. Translated by John Carter. London: Penguin Classics, 1996.

Asconius, On Cicero's Pro Milone. Translated by R.G. Lewis. Oxford University Press, 2007.

Cicero, M. Tullius. Cicero: Epistulae ad Familiares: Volume 1, 62-47 B.C. Edited by D. R. Shackleton-Bailey. Cambridge: Cambridge University Press, 2004.

-----. Cicero: Epistulae ad Familiares: Volume 2, 47-43 B.C. Edited by D. R. Shackleton-Bailey. Cambridge: Cambridge University Press, 2004.

-----. Cicero: Epistulae ad Quintum Fratrem et M. Brutum. Edited by D. R. Shackleton-Bailey. Cambridge: Cambridge University Press, 2004.

-----. Cicero: Philippics I-II. Edited by John T. Ramsey. Cambridge: Cambridge University Press, 2003.

Plutarch. Parallel Lives. Translated by Bernadette Perrin. Loeb Classical Library Edition. Cambridge: Harvard University Press, 1920.

Sallust, Gaius Crispus. Catiline's War, The Jugurthine War, Histories. Edited and translated by A. J. Woodman. London: Penguin Classics, 2008.

Suetonius. The Twelve Caesars. Edited by James Rives and translated Robert Graves. London: Penguin Books Ltd., 2007.

Valerius Maximus. Memorable Deeds and Sayings: A Thousand Tales from Ancient Rome. Translated by Henry John Walker. Hackett Publishing Co. Inc., 2004.

Velleius Patercullus, The Roman History. Translated by Frederick W. Shipley. Loeb Classical Library Edition. Cambridge: Harvard University Press, 1924. 


\section{Secondary Sources}

Abbott, Frank W. Society and Politics in Ancient Rome. NY: Charles Scribner's Sons, 1909.

Ackert, Nick. "Animus After Actium? Antony, Augustus, and Damnatio Memoriae.” Discentes 4 (Apr., 2016): 32-40.

Adams, J.N. The Latin Sexual Vocabulary. Baltimore: The Johns Hopkins University Press, 1982.

Allen, Walter, Jr. "Cicero's House and Libertas," Transactions and Proceedings of the American Philological Association 75 (1944), 1-9.

Anderson, Andrew Runni. "Heracles and His Successors: A Study of a Heroic Ideal and the Recurrence of a Heroic Type." Harvard Studies in Classical Philology 39 (1928): 7-58.

Babcock, Charles L. "Dio and Plutarch on the Damnatio of Antony." Classical Philology 57 (Jan., 1962): 30-32.

-----. "The Early Career of Fulvia.” The Journal of American Philology 86 (Jan., 1965): 1-32.

Bauman. Richard A. Women and Politics in Ancient Rome. London: Routledge, 1992.

Bayle, Pierre, et al. The Dictionary: Historical and Critical of Mr. Peter Bayle Volume 3, London: The Royal Society, 1736.

Beard, Mary. Confronting the Classics: Traditions, Adventures and Innovations. NY: Liveright Publishing, 2013.

----. “The Public Voice of Women,” London Review of Books, 36.6 (Mar. 2014): $11-14$

Best, Edward E., Jr. "Cicero, Livy, and Educated Roman Women.” The Classical Journal 65.6 (Feb., 1970): 199-204.

Bellow, Juliet. "Fashioning Cléopâtre: Sonia Delaunay's New Woman.” Art Journal 68. 9 (Summer, 2009): 6-25.

Beneker, Jeffery. The Passionate Statesman: Eros and Politics in Plutarch's Lives. Oxford: Oxford Press, 2012.

Bennett, Harold. "Vergil and Pollio." The American Journal of Philology, 51.4 (1930): $325-342$. 
Best, E.E. Jr. "Cicero, Livy and Educated Roman Women." Classical Journal 65. 5 (1970): 199-204.

Bowditch, Lowell. "Propertius and the Gendered Rhetoric of Luxury and Empire: A Reading of 2.16," Comparative Literature Studies, 43.3 (2006): 306-325.

Boyd, Barbara Weiden, "Virtus Effeminata and Sallust's Sempronia,” Transactions of the American Philological Association 117 (1987): 183-201.

Brennan, T. Corey. "Perceptions of Women's Power in the Late Republic: Terentia, Fulvia, and the Generation of 63 BCE." In A Companion to Women in the Ancient World, edited by Sharon L. James and Sheila Dillion, 354-366. Sussex, UK: Wiley-Blackwell Publishing, Inc. 2012.

Broughton, T.R.S. The Magistrates of the Roman Republic. New York: American Philological Association, 1951.

Buszard, Bradley. "The Speech of Greek and Roman Women in Plutarch's Lives." Classical Philology 105, 1 (Jan., 2010): 83-115.

Carney, Elizabeth D. "Olympias and the Image of the Virago." Phoenix 47 (Spring, 1993): 29-55.

Chrystal, Paul. Women in Ancient Rome. Gloucestershire: Amberley Publishing, 2014.

Clark, Albert C., ed. Cicero, Pro T. Annio Milone. Ad Iudices Oratio. Amsterdam,: A. M. Hakkert, 1895.

Clark, Gillian. "Roman Women," Greece \& Rome 28.2 (Oct., 1981): 193-212.

-----. "Silence and Women in Greece \& Rome,” Greece \& Rome 50 (2003): 132134.

-----. Women in the Ancient World: Greece \& Rome. Oxford: Oxford University Press, 1989.

Corbeill, Antony. Controlling Laughter: Political Humor in the Late Roman Republic. Princeton, NJ: Princeton University Press, 1996.

Crook, John. “A Legal Point about Mark Antony's Will.” The Journal of Roman Studies 47.5 (1957): 36-8.

Crownover, Emma. "The Clash between Clodia and Cicero." The Classical Journal 30. 3 (Dec., 1934): 137-147.

Delia, Diana. "Fulvia Reconsidered" in Women's History as Ancient History. Edited by Sarah B. Pomeroy, 197-217. Chapel Hill: University of North Carolina Press, 1991. 
Dixon, Suzanne. Reading Roman Women: Sources, Genres, and Real Life. London: Duckworth Publishing, 2007.

----. "The Enduring Theme: Domineering Dowagers and Scheming Concubines," in Stereotypes of Women in Power: Historical Perspectives and Revisionist Views, edited by Barbara Garlick, Suzanne Dixon, and Pauline Allen, 181-209. New York: Greenwood Press, 1992. -----. "Unsexing Fulvia: A Dangerously Undomesticated Roman Wife," dangerouswomenproject.org, July 19, 2016, http://dangerouswomenproject.org/2016/07/19/unsexing-fulvia/

Dominik, William J. "The Style is the Man." in Roman Eloquence: Rhetoric in Society and Literature, edited by William J. Dominik, 50-70. London: Routledge, 1997.

Duroy, Victor. History of Rome and the Roman People. Boston: Dana Estes and Charles Lauriat, 1884.

Duff, Tim. Plutarch's Lives: Exploring Virtue and Vice. Oxford: Clarendon Press, 1999. de Wet, B.X. "Contemporary Sources in Plutarch's Life of Antony," Hermes 118 B\&H 1 (199): 80-90.

Edwards, Catharine. The Politics of Immorality in Ancient Rome. Cambridge: Cambridge University Press, 1993.

Epstein, David F. “Cicero's Testimony at the Bona dea Trial.” Classical Philology, 81 (Jul., 1986): 229-235.

Fielding, Sarah. The Lives of Cleopatra and Octavia. 1757. Reprint, NY and London: Garland Publishing, Inc.,1974.

Fischler, Susan, "Social Stereotypes and Historical Analysis: The Case of the Imperial Women at Rome," in Women in Ancient Societies: An Illusion of the Night. Edited by Léonie J. Archer, Susan Fischler, and Maria Wyke, 115-132. Macmillan, 1994.

Fowle, A.L. Makers of History: Cleopatra. NY: Makers of History, 1906.

Fraschetti, Augusto, ed. Roman Women. Translated by Linda Lappin. Chicago: University of Chicago Press, 2001.

Freyburger-Galland, Marie-Laure. "Political and Religious Propaganda Between 44 and 27 BC.” Vergilius 55 (2009): 17-30.

Gabba, Emilio. "The Perusine War and Triumviral Italy." Harvard Studies in Classical Philology 75 (1971): 139-160.

Gadeken, Sara. "Gender, Empire, and Nation in Sarah Fielding's Lives of Cleopatra and Octavia." Studies in English Literature, 1500-1900, 39.3 (Summer, 1999): 523538 . 
Geiger, Joseph. "Book Review: Mark Antony: His Life and Times," The Classical Review, 40.1 (Jan., 1990): 179-180.

G.I.C. "Reviewed Work: Marc Antony: His World and His Contemporaries by Jack Lindsay," Greece \& Rome 6.17 (Feb., 1937): 123.

Golden, Mark, and Peter Toohey, eds. Sex and Difference in Ancient Greece and Rome. Edinburgh: Edinburgh University Press, 2003.

Gowing, Alain M. The Triumviral Narratives of Appian and Cassius Dio. Ann Arbor: University of Michigan Press, 1992.

Grant, Michael. Cleopatra. NY: Simon \& Schuster, 1972.

Griffin, J. Latin Poets and Roman Life. NC: Chapel Hill Press, 1985.

Gunderson, Erik. Staging Masculinity: The Rhetoric of Performance in the Roman World. Ann Arbor: University of Michigan Press, 2000.

Hallett, Judith. Fathers and Daughters in Roman Society: Women and the Elite Family. Princeton: Princeton University Press, 1984.

----- "Fulvia, Mother of Iullus Antonius: New Approaches to the Sources on Julia's Adultery at Rome," Helios 33.2 (2006), 149-165.

----- "Fulvia: The Representation of an Elite Roman Woman Warrior." in Women \&War in Antiquity, edited by Jacqueline Fabre-Serris and Alison Keith, 247-265. Baltimore: Johns Hopkins Press, 2015.

----. "Perusinae Glandes and the Changing Image of Augustus." AJAH 2 (1977): $151-71$.

----. "Women as the Same and Other in Classical Roman Elite." Helios 16 (1989): 59-78.

Hallett, Judith P. and Marilyn B. Skinner, eds. Roman Sexualities. Princeton: Princeton University Press, 1997.

Hawley, Richard, and Barbara Levick. Women in Antiquity : New Assessments. London: Routledge, 1995.

Hazel, John. Who's Who in the Roman World. Routledge, 2001.

Hemelrijk, Emily A. Matrona Docta: Educated Women in the Roman Elite from Cornelia to Julia Domna. London: Routledge, 1999.

----. "Masculinity and Femininity in the "Laudatio Turiae."” The Classical Quarterly 2, 54.1 (May, 2004): 185-197. 
Hillard, Tom. "On the Stage, Behind the Curtain." In Stereotypes of Women in Power : Historical Perspectives and Revisionist Views, edited by Barbara Garlick, Suzanne Dixon and Pauline Allen, 37-64. New York: Greenwood Press, 1992.

----. "Plutarch's Late Republican Lives." Antichthon 21 (1987): 19-48.

-----. "Republican Politics, Women and the Evidence." Helios 16 (1989): 165-182.

Houssaye, Henry. Cleopatra, A Study. NY: Duprat \& Co., 1890.

Hughes-Hallett, Lucy. Cleopatra: Queen, Lover, Legend. London: Pimlico Publishing, 2006.

Huzar, Eleanor G. Mark Antony: A Biography. Minneapolis: University of Minnesota Press, 1978.

----. "Mark Antony: Marriages vs. Careers." The Classical Journal 81 (Dec., 1985-Jan.,1986): 97-111.

Ige, S. "Rhetoric and the Feminine Characterization of Cicero's Portrayal of Sassia, Clodia, and Fulvia." Akroterion 48 (2003): 45-57.

Jestice, Phyllis G. "Fulvia" in Women and War: A Historical Encyclopedia from Antiquity to the Present, Volume 2. Edited by Bernard Cook. Santa Barbara: ABC-Clio, 2006.

Jones, C.P. Plutarch and Rome. Oxford: Clarendon Press, 1971.

Kapust, Daniel J. Republicanism, Rhetoric, and Roman Political Thought: Sallust, Livy, and Tacitus. NY: Cambridge University Press, 2011.

Kelly-Gadol, Joan. "Did Women Have a Renaissance?" in Women, History, and Theory: The Essays of Joan Kelly, edited by Catharine R. Stimpson, 19-51. Chicago: University of Chicago Press, 1984.

Kelly, Rachel. Mark Antony and Popular Culture: Masculinity and the Construction of an Icon. New York, New York: I.B. Taurus and Company, Ltd/Palgrave Macmillan, 2014.

Keith, Alison. "Lycoris Galli/Volumnia Cytheris: a Greek Courtesan in Rome." EuGeStA 1 (2011): 23-53.

Kittredge, Mary. Marc Antony, NY: Chelsea House Publishers, 1988.

Kleiner, Diana E.E. "Politics and Gender in the Pictorial Propaganda of Antony and Octavian," Echoes du Monde Classique 36,11 (1992): 357-67.

Kirby, John T. "Ciceronian Rhetoric: Theory and Practice" in Roman Eloquence: Rhetoric in Society and Literature edited by William J. Dominik. London: Routledge, 1997: 13-31. 
Lacey, W.K. “The Tribunate of Curio,” Historia, X (1961): 318-29.

Langis, Unhae. "Virtuous Viragos: Female Heroism and Ethical Action in Shakespearean Drama" Literature Compass 7.6 (2010): 397-411.

Lardinois, A. P. M. H. and Laura McClure. Making Silence Speak: Women's Voices in Greek literature and Society. Princeton, N.J.: Princeton University Press, 2001.

Leach, Eleanor Winsor, "Gendering Clodius.” The Classical World 94.4 (Summer, 2001): 335-59.

Lindsay, Jack. Cleopatra. London: History Book Club, Ox and Wyman Ltd, 1971. -----. Marc Antony: His World and his Contemporaries. George Routledge and Sons, Ltd., 1936.

Luce, J.V. "Cleopatra as Fatale Monstrum (Horace, Carm. 1.37.21) The Classical Quarterly 13, 2 (Nov., 1963): 251-7.

Ludwig, Emil. Cleopatra: Story of a Queen. NY: Viking Press, 1937.

Malamud, Margaret. Ancient Rome and Modern America. John Wiley \& Sons, 2007.

Manwald, Gesine. "The Speeches to the People in Cicero's Oratorical Corpora." Rhetorica: A Journal of the History of Rhetoric 30, 2 (Spring, 2012): 153-175.

Marzolf, Marion Tuttle. Civilizing Voices: American Press Criticism 1880-1950. White Plains, NY: Longman Publishing Group, 1991.

Massie, Allan. Antony. London: Hodder and Stoughton, 1997.

May, J.M. "Cicero: His Life and Career." In Brill's Companion to Cicero: Oratory and Rhetoric, ed. J.M. May, 1-22. Leiden: Brill, 2002. -----.Trials of Character: The Eloquence of Ciceronian Ethos. Chapel Hill: The University of North Carolina Press, 1988.

Marsh, Frank Burr. "The Policy of Clodius from 58 to 56 B.C." The Classical Quarterly, 21 (Jan., 1927): 30-36.

McCabe, Joseph. The Empresses of Rome. NY: Henry Holt \& Co., 1911.

McDonnell, Myles. Roman Manliness: Virtus and the Roman Republic. New York: Cambridge University Press, 2006.

McManus, Barbara F. Classics and Feminism: Gendering the Classics. New York: Twayne Publishers and Prentice Hall International, 1997. 
McJannet, Linda. "Antony and Alexander: Imperial Politics in Plutarch, Shakespeare, and Some Modern Historical Texts.” College Literature 20, No. 3 (Oct., 1993): 1-18.

Myers, Nancy. "Cicero's (S)Trumpet: Roman Women and the Second Philippic." Rhetoric Review, 22 (4, 2003): 337-352.

Millar, Fergus. "Cornelius Nepos, 'Atticus' and the Roman Revolution.” Greece \& Rome 35, 1 (Apr. 88): 40-55.

-----. The Crowd in Rome in the Late Republic. Ann Arbor: University of Michigan Press, 1998.

Milnor, Kristina. Gender, Domesticity, and the Age of Augustus. Oxford: Oxford University Press, 2005.

Morgan, Llewelyn. "The Autopsy of C. Asinius Pollio.” The Journal of Roman Studies 90 (2000): 51-69.

Morstein-Marx, Richard. Mass Oratory and Political Power in the Late Republic. Cambridge: Cambridge University Press, 2004.

Offen, Karen. "Defining Feminism: A Comparative Historical Approach," Signs 14, (1988): 119-157.

Parker, Holt N. "The Tetragenic Grid." In Sexuality in Greek and Roman Culture. Edited by Marilyn B. Skinner. Blackwell Publishing, 2005:47-65.

Pelling, C.B.R. ed. Life of Antony. Cambridge: Cambridge University Press, 1988.

-----. "Plutarch's Adaptation of His Source Material." Journal of Hellenic Studies, 100 (1980): 127-140.

-----. "Plutarch's Method of Work in the Roman Lives." Journal of Hellenic Studies, 99 (1979): 74-96.

-----."Plutarch's Method of Work in the Roman Lives," in Essays on Plutarch's Lives. Edited by Barbara Scardigli. Oxford: Clarendon Press, 1995: 265-318. ----."The Triumviral Period." In Cambridge Ancient History, ed. A.K. Bowman et al, 10, 1-69. Cambridge: Cambridge University Press, 1996.

Peradotto, John, and J.P. Sullivan. Women in the Ancient World: The Arethusa Papers. Albany: State University of New York Press, 1984.

Pomeroy, Sarah B. Goddesses, Whores, Wives, and Slaves: Women in Classical Antiquity. New York: Schocken Books, 1975, 1995.

-----. Women's History and Ancient History. Chapel Hill: University of North Carolina Press, 1991.

Powell, J.G.F. "Procedural Influences on the Structure of the Argument in Cicero's Defence Speeches." In Form and Function in Roman Oratory. Edinburgh, 2007. 
Ramsey, J.T. "Did Mark Antony Contemplate an Alliance with His Political Enemies in July 44 B.C.E.?" Classical Philology 96, no. 3 (2001): 253-268.

-----. ed. Cicero: Philippics 1-2, Cambridge Greek and Latin Classics. Cambridge: Cambridge University Press, 2003.

-----. "Cicero's Thirteenth Philippic: A Unique Solution to a Rhetorical

Dilemma." In Form and Function in Roman Oratory. Edinburgh, 2007.

Reinhold, Meyer. “The Perusine War.” The Classical Weekly 26 (Apr., 1933): 180-182.

Richlin, Amy. "Approaches to the Sources on Adultery in Rome," "Invective Against Women in Satire," and "Julia's Jokes, Galla Placidia, and the Roman Use of Women as Political Icons." In Arguments with Silence: Writing the History of Roman Women. Ann Arbor, MI: University of Michigan, 2014: 36-61, 62-80, 81 102.

-----. "Cicero's Head," in Constructions of the Classical Body. Edited by James I. Porter. Ann Arbor: University of Michigan Press, 1999.

-----. The Garden of Priapus: Sexuality and Aggression in Roman Humor. New Haven: Yale University Press, 1983.

-----. "Gender and Rhetoric Producing Manhood in the Schools," in Roman Eloquence: Rhetoric in Society and Literature edited by William J. Dominik. London: Routledge, 1997: 90-110.

-----. "Roman Use of Women as Political Icons." In Stereotypes of Women in Power: Historical Perspectives and Revisionist Views, Edited by Barbara Garlick, Suzanne Dixon and Pauline Allen, 65-91. New York: Greenwood Press, 1992.

Reubitscheck, Antony E. "Octavia's Deification at Athens.” The Transactions and Proceedings of the American Philological Association 77 (1946): 146-150.

Roberts, Alan. Mark Antony: His Life and Times. Worcestershire, UK: Malvern Publishing Co. Ltd, 1988.

Roller, Matthew B. “Color-blindness: Cicero's Death, Declamation, and the Production of History." Classical Philology 92 (Apr., 19970: 109-130.

Russell, Brigetta Ford. "The Emasculation of Antony; the Construction of Gender in Plutarch's Life of Antony. " Helios 25.2 (1999): 121-37.

Saller, Richard. "Anecdotes as Historical Evidence for the Principate," Greece \& Rome 27.1 (Apr., 1980): 69-83.

Salisbury, Joyce E. Encyclopedia of Women in the Ancient World. ABC-Clio, 2001.

Saxonhouse, Arlene W. Women in the History or Political Thought: Ancient Greece to Machiavelli. NY: Prager Publishing, 1985. 
Schiedel, W. "The Most Silent Women of Greece and Rome: Rural Labor and Women's Life in the Ancient World," Part I. Greece \& Rome, 42.2, (Oct., 1995): 202-17.

Scott, Joan. "Gender: A useful Categorical Analysis," The American Historical Review 91 (Dec., 1986): 1053-1075.

Scott, Kenneth. “Octavian's Propaganda and Antony’s De Sua Ebrietate.” Classical Philology, 24 (Apr. 1929): 133-141.

-----. "The Political Propaganda of 44-33 B.C." MAAR 11 (1933): 1-49.

Sergeant, Philip W. Cleopatra of Egypt: Antiquity's Queen of Romance. NY: George H. Doran Publishers, 1909.

Shakespeare, William. The Complete Works of William Shakespeare. Edited by W.G. Clark and W. Aldis Wright. NY: Programmed Classics, 1992.

Shelton, Jo-Ann. As The Romans Did: A Sourcebook in Roman Social History. New York: Oxford University Press, 1998.

Skeat, Walter W. Shakespeare's Plutarch: Being a Selection from 'The Lives' in North's Plutarch Which Illustrate Shakespeare's Plays. London: MacMillan and Co., 1875.

Skinner, Marilyn. Clodia Metelli: The Tribune’s Sister. Oxford: Oxford University Press, 2011.

-----. Editor. Rescuing Creusa: New Methodological Approaches to Women in Antiquity: A Special Issue of 'Helios' 13.2 (1986).

-----. Sexuality in Greek and Roman Culture. Blackwell Publishing, 2005.

Sorkin Rabinowitz, Nancy, and Amy Richlin, eds. Feminist Theory and the Classics. New York: Routledge, 1993.

Southern, Patricia. Marc Antony: A Life. Gloucestershire, UK: Anberly Publishing, 2012.

Stoddart, Simon, et al. "Opening the Frontier: The Gubbio-Perugia Frontier in the Course of History." Papers of the British School at Rome 80 (2012):257-294.

Sumi, Geoffrey S. "Power and Ritual: The Crowd at Clodius' Funeral." Historia: Zeitschrift für Alte Geschichte, 46 (1st Qtr., 1997): 80-102.

Swain, Simon, "Novel and Pantomime in Plutarch's Antony," Hermes 120 (1992): 76-82.

Syme, Ronald. The Roman Revolution. Oxford University Press, 2002.

Takács, Sarolta A. Vestal Virgins, Sibyls, and Matrons: Women in Roman Religion. 
Austin: University of Texas Press, 2008.

Tatum, W. Jeffrey. The Patrician Tribune. Chapel Hill: University of North Carolina Press, 1999.

-----. "Invective Identities in Cicero's Pro Caelio." In Praise and Blame in Roman Oratory. St. Andrews, 2006.

Taylor, Barry. Fulvia or Hercules and the Creature. Essex: Maypole Editions, 2001.

Taylor, Lily Ross, Party Politics in the Age of Caesar. University of California Press, 1961.

Traina, G. "Lycoris the Mime." Roman Women. Edited by Augusto Fraschetti. Translated by Linda Lappin. Chicago: University of Chicago Press, 2001. 82-99

Tempest, Kathryn. Cicero: Politics and Persuasion in Ancient Rome. London: Bloomsbury Academic, 2014.

Treggiari, Susan. "The Influence of Roman Women." CR 36 (1986): 102-105. ----. Roman Marriage: Iusti Coniuges from the Time of Cicero to the Time of Ulpian. Oxford: Oxford University Press, 1991.

----. "Women in the Time of Augustus." In The Cambridge Companion to the Age of Augustus. Edited by K. Galinsky, 130-147. Cambridge: Cambridge University Press, 2005.

Usher, Stephen. "Cicero's 'First Philippic' and the Fall of the Republic." Bulletin of the Institute of Classical Studies. 53, 1 (2010): 129-136.

Vasvári, Louise O. "Examples of the Motif of the Shrew in European Literature and Film," Comparative Literature and Culture 4.1 (2002): 1-8.

Virlouvet, Catherine. "Fulvia, Woman of Passion," in Roman Women. Edited by Augusto Fraschetti. Translated by Linda Lappin. Chicago: University of Chicago Press, 2001, 66-80.

Waters, Jonathon. "Invading the Roman Body: Manliness and Impenetrability in Roman Thought." In Roman Sexualities edited by Judith P. Hallett and Marilyn B. Skinner. (Princeton: Princeton University Press, 1997): 29-43.

Welch, Kathryn E. "Antony, Fulvia, and the Ghost of Clodius in 47 BC." Greece \& Rome 42 (Oct., 95): 182-201.

Weiand, Helen E. "The Position of Women in the Late Republic. Part II" The Classical Journal, 12.7 (Apr., 1917 ): 423-437.

Weigall, Arthur. Cleopatra Queen of Egypt. NY: Garden City Publishing, Inc., 1924. 
-----. The Life and Times of Marc Antony. Garden City, NY: Garden City Publishing Company, Inc., 1931.

Weir, Allison Jean, “A Study of Fulvia.” Master's thesis, Queen's University, 2007.

Wiseman, T.P. New Men in the Roman Senate: 139 BC- AD 14. Oxford: Oxford University Press, 1971.

----. "The Last Age of the Roman Republic, 146-43 B.C." In Cambridge

Ancient History. Edited by J.A. Crook, A. Lintott and E. Rawson, 9. Cambridge: Cambridge University Press, 1994.

Witzke, Serena, "Censure of Powerful Women: Roman Monarchy and Gender Anxiety." Master's thesis, McMaster University, 2007.

Woodman, A.J. Velleius Paterculus: The Caesarian and Augustan Narrative 82.4193. Cambridge: Cambridge University Press, 1983.

Wooten, C.W. Cicero's Philippics and Their Demosthenic Model: The Rhetoric of Crisis. Chapel Hill: The University of North Carolina Press, 1983.

Wright, Andrew. "The Death of Cicero, Forming a Tradition: The Contamination of History." Historia 50.4 (2001): 436-452.

-----. "Velleius Paterculus and L. Munatius Plancus." Classical Philology, 97 (Apr., 2002): 178-184.

Wyke, Maria. Caesar in the USA. University of California Press, 2012.

-----. The Roman Mistress: Ancient and Modern Representations. Oxford University Press, 2007.

Zager, Ilona. "The Political Role of Women of the Roman Elite, with Particular Attention to the Autonomy and Influence of the Julio-Claudian Women (44 BCE To CE 68)." Master's thesis, University of South Africa, 2014.

Zanker, Paul. The Power of Images in the Age of Augustus. Translated by Alan Shapiro. Ann Arbor: University of Michigan Press, 1990. 


\section{APPENDIX}

\section{COINS AND BULLETS}

Antony's Coins Featuring Fulvia:

Figure $\mathrm{I}^{1}$ :
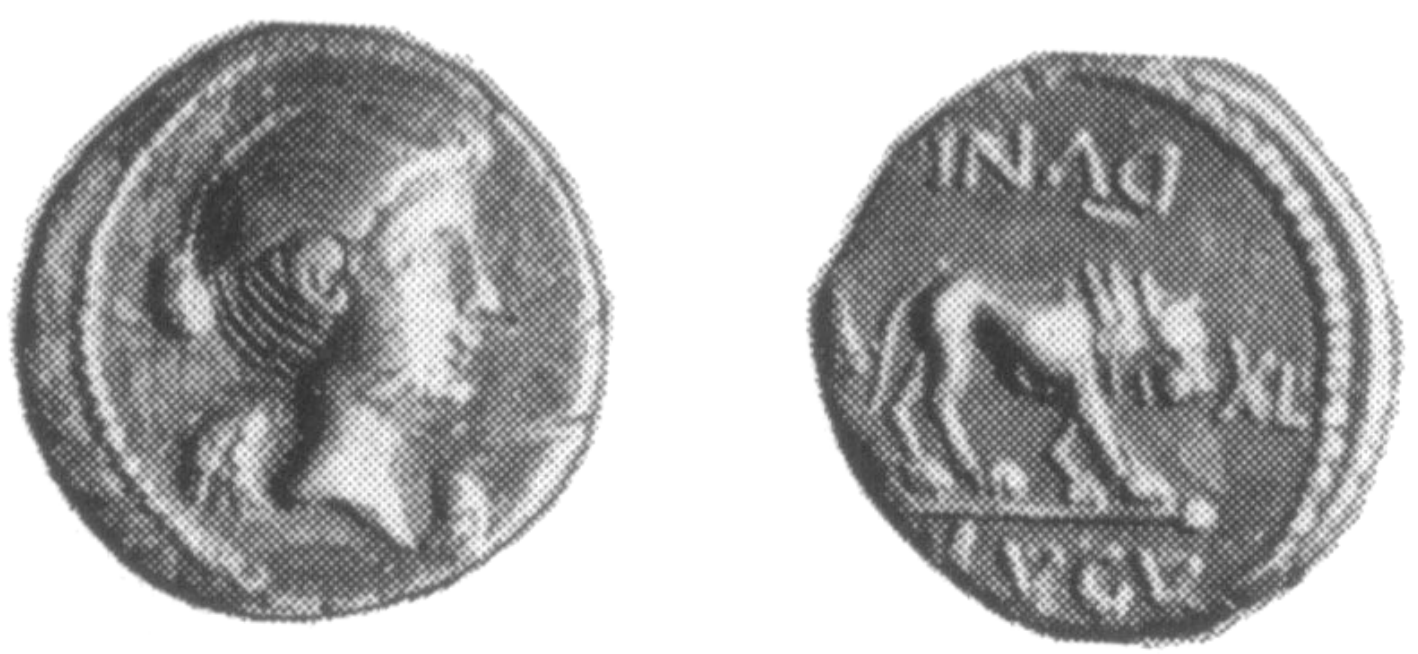

Winged bust facing right, her hair styled into a middle-placed knot below one long twisted plait arranged (nodus). Wings cramped.

Reverse: lion walking to right, in reference to Lugdunum of Antony's Zodiac sign. LVGV/DVNI (Lugdunum) in exergue and above, $\mathrm{A}$ (nno) on left, $\mathrm{XL}$ on right, to recognize Antony's 40th birthday. Silver quinarius. Lugdunum, 43 BCE. (RRC at. no. 489/5; Sydenham cat. no. 1160; BMCRR Gaul cat. no. 40; Babelon Antonia cat. no. 32; RPC 512).

${ }^{1}$ D.R. Sear, The History and Coinage of the Roman Imperators 49-27 B.C., (London: Spink, 1998), cat. no. 122. 
Figure II: ${ }^{2}$
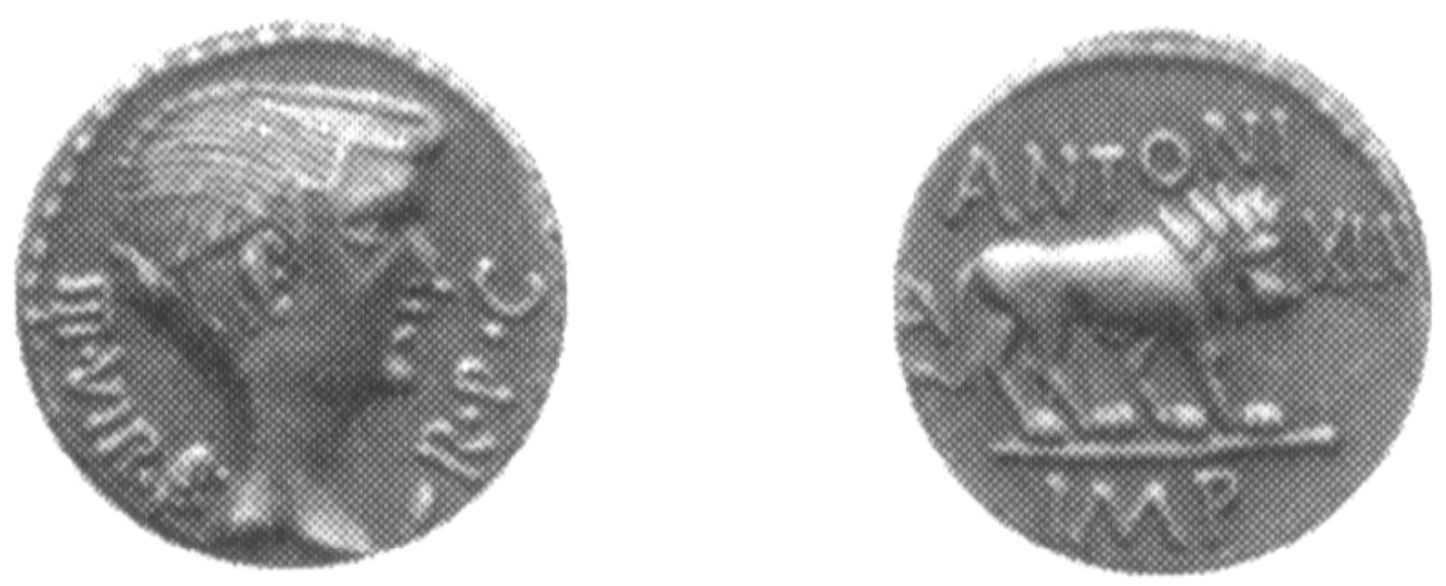

Winged bust of Victoria right, hair same style as figure I.

III VIR (triumvir) behind, R P C (rei publicae constituendae) ${ }^{3}$ before. Very small wings.

Reverse: lion walking right, ANTONI above, IMP (Imperator) in exergue,

A on left, XLI on right for Antony's 41st birthday. Silver Quinarius. Lugdunum, 42 BCE.

(RRC cat. no. 489/6; Sydenham cat. no. 1163; BMCRR Gaul cat.

No. 48; Babelon Antonia cat. no. 32; RPC cat. no. 513).

${ }^{2}$ Sear, History and Coinage, cat. no. 126.

${ }^{3}$ rei publicae constituendae means "for the restoration of the Republic." 
Figure III ${ }^{4}$ :
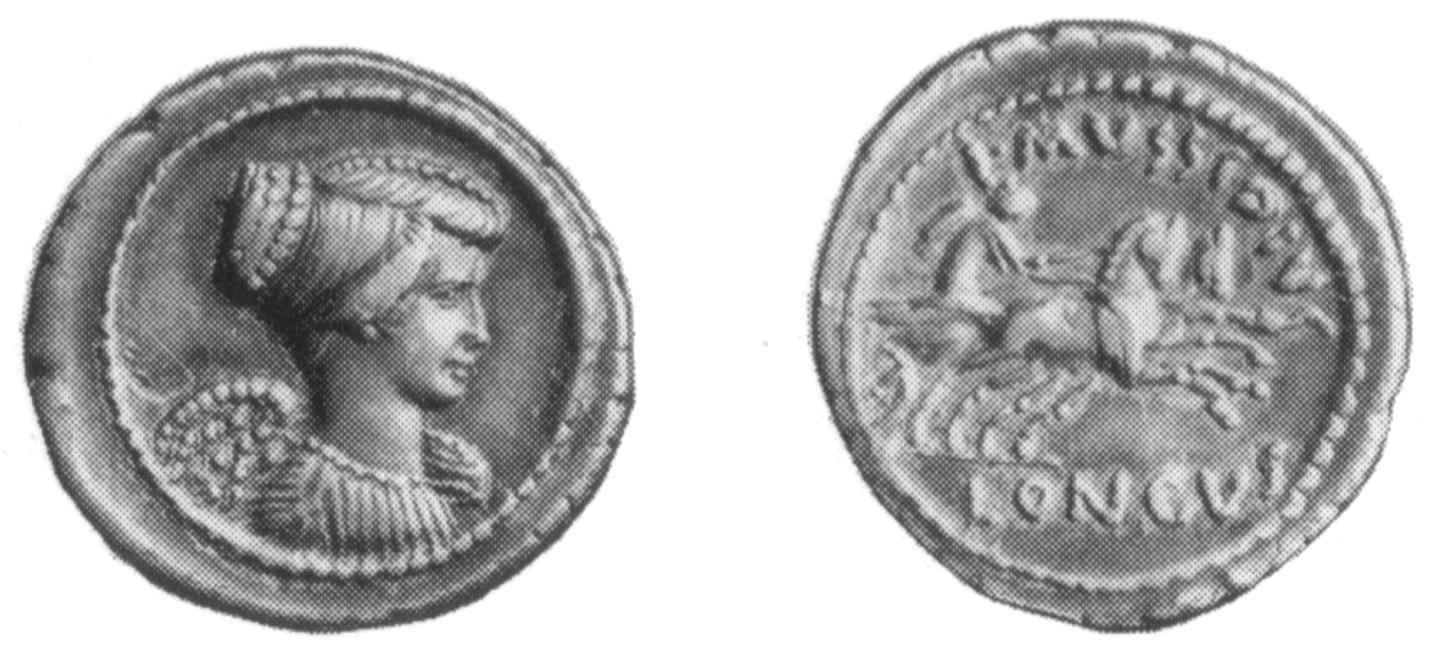

Winged bust of right, hair braided in twisted row on the top of her head and coiled around high knot at the back. Large, detailed wings.

Reverse: Victoria in galloping biga (two-horse chariot) right, L MVSSIDIVS above, LONGVS below.

Silver denarius. Rome, 42 BCE (RRC cat.no. 494/40; Sydenham cat. no. 1095; BMCRR cat. no. 4229; Babelon, Mussidia, cat.no. 4).

${ }^{4}$ Sear, History and Coinage, cat. no. 186. 
Figure $\mathrm{IV}^{5}$ :
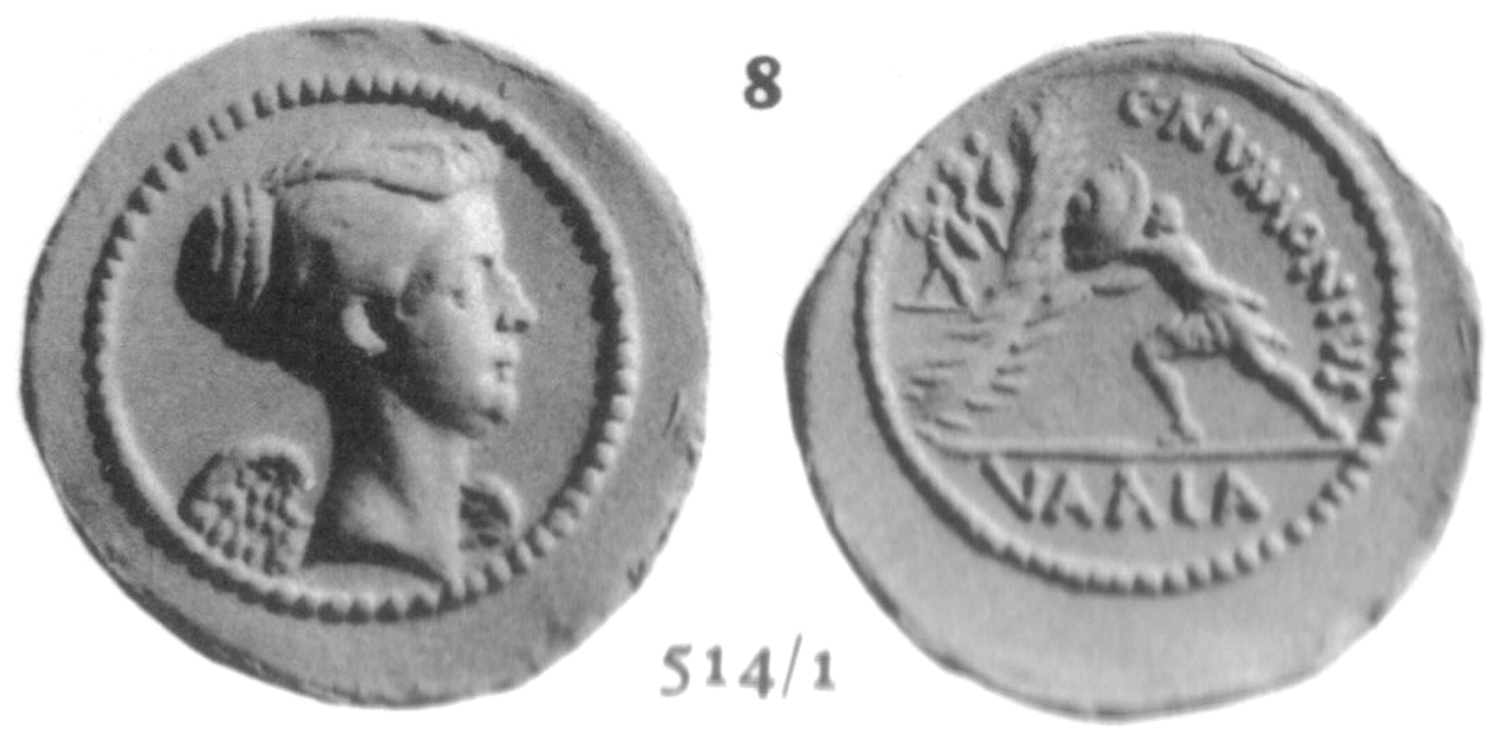

Winged bust of Victoria right, same hair style as figure IV. Detailed wings.

Reverse: soldier advancing left, with sword and shield, attacking a palisade wall with two armed soldiers behind it.

C NVMONIVS on right, VAALA in exergue. Gold aureus. Rome, 41 BCE (RRC cat. no. 514/1; Sydenham cat. no. 1086; BMCRR cat. no. 4215; Babelon, Numonia, cat. no. 1).

${ }^{5}$ M. Crawford, Roman Republican Coinage, (Cambridge: Cambridge University Press, 1974), cat. no. 514/1. 
Figure $\mathrm{V}^{6}$ :
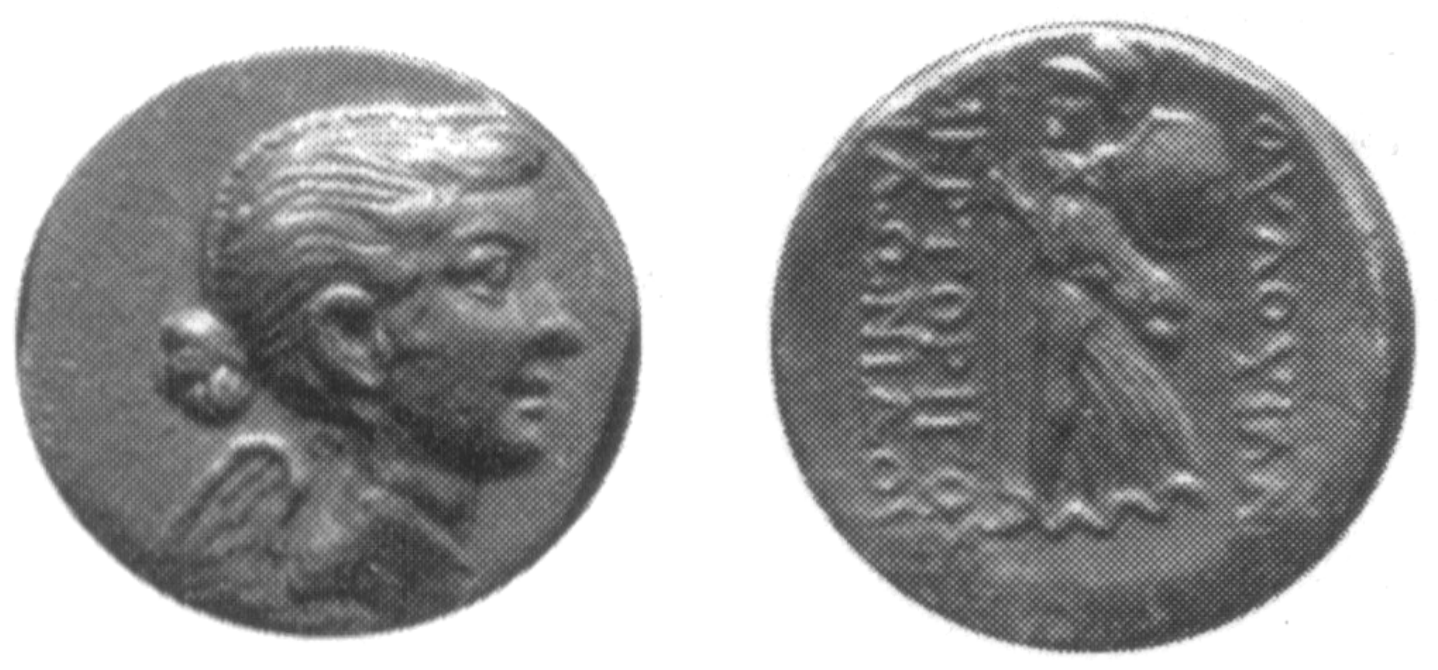

Winged and draped bust right, hair drawn back and braided from crown to low, tied knot at the base of her neck.

Reverse: ФOY $\Lambda$ OYIAN $\Omega$ on left, ZMEPTOРIГO $\Sigma$ on right. Athena advancing left with vertical spear and shield. Leaded bronze. Phrygia, 41-40 BCE (B. V.

Head, cat. no. 213; RPC Eumenea, cat. no. 3139).

${ }^{6}$ Sear, History and Coinage, 83. Eumenia was a Phrygian city of which Fulvia was patron. The city of temporarily named Fulviana. 
Figure $\mathrm{VI}^{7}$ :

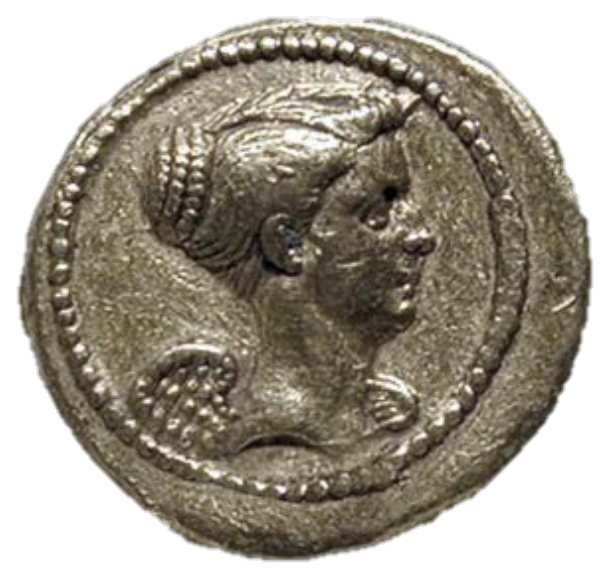

Winged bust right, same hair style as figure IV. Detailed wings.

No reverse image available. Golden aureus, minted at Rome, C. Numonius Vaala, c. 41

BCE. (Rome, Palazzo Massimo alle Terme. Credits: Barbara

McManus, 2003).

\footnotetext{
${ }^{7}$ Rome, Palazzo Massimo alle Terme (National Museums). Credits: Barbara McManus, 2003.
} 


\section{Perusine Glandes}

Figure VII ${ }^{1}$ :

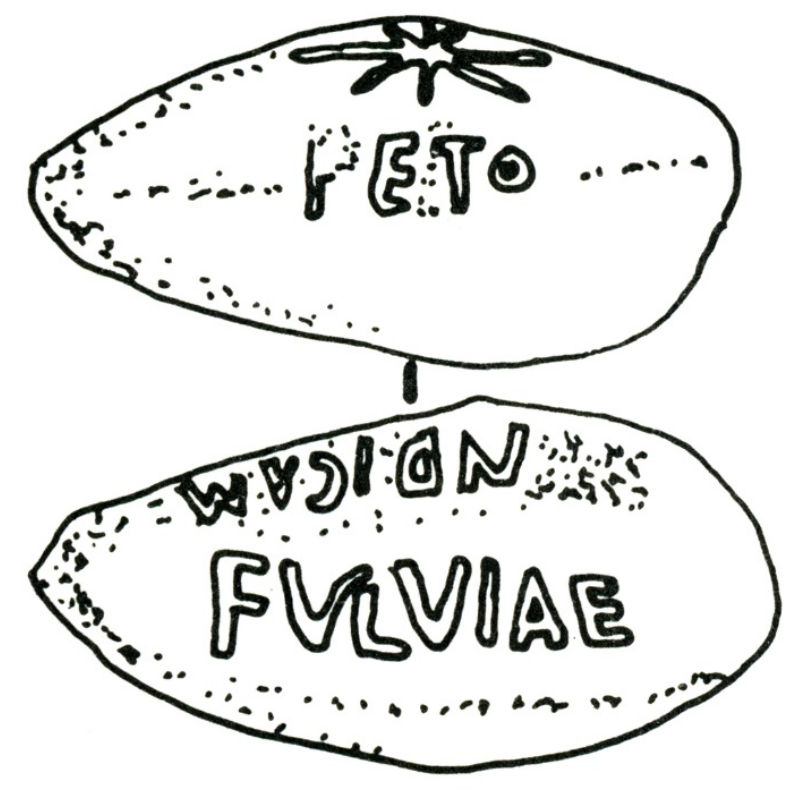

Sling ball in a mold: embossed. Side 1: PETO; Side 2: ...NDICAM / FVLVIAE.

${ }^{1}$ L. Keppie, The Making of the Roman Army, from Republic to Empire, London 1984, 124, 
Figure VIII'

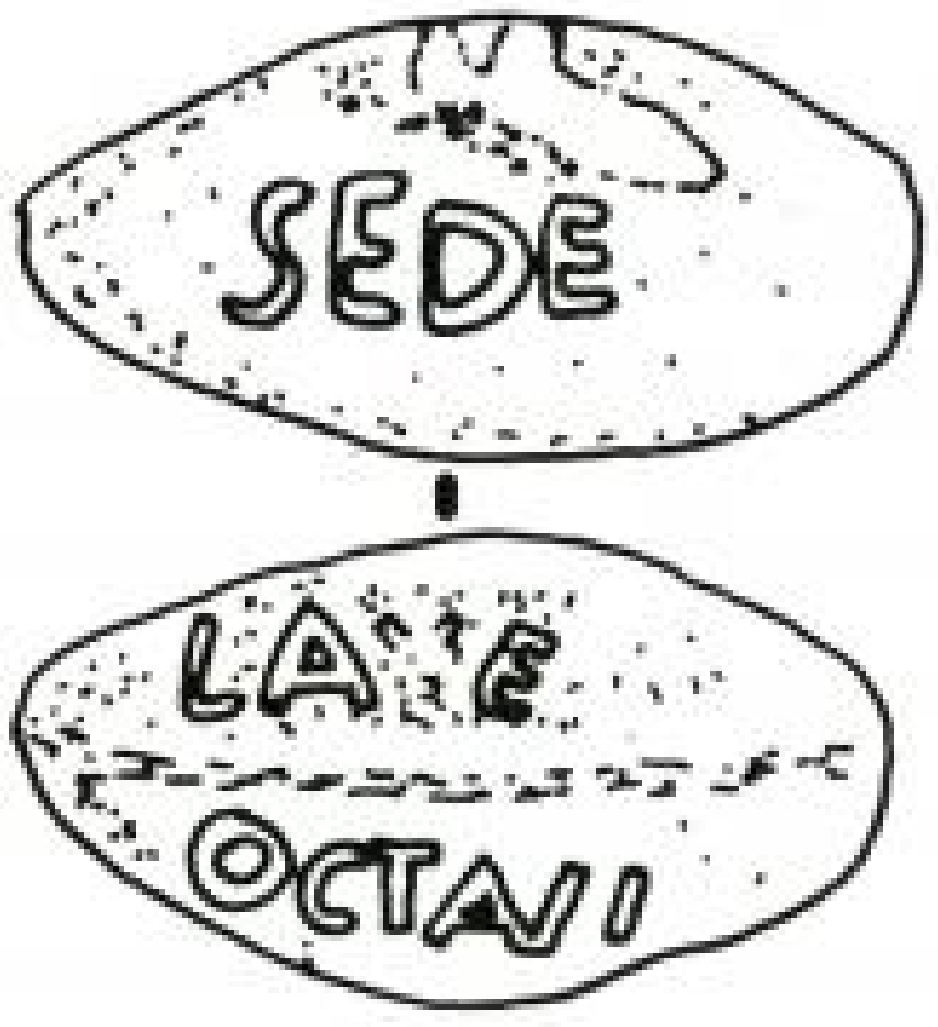

Sling ball in a mold: embossed. Side 1: SEDE; Side 2: LA..E / OCTAVI.

${ }^{2}$ Ibid., 124. 
PRIMARY SOURCE ABBREVIATIONS

App. B. Civ.

Arist. Pol.

Asc. Mil.

Cic. Ad Brut.

Cic. Att.

Cic. Cael.

Cic. Catil.

Cic. Fam.

Cic. Har. Res.

Cic. Mil.

Cic. Sest.

Cic. Prov

Cic. Phil.

Cic. Q. Fr.

Cic. Verr.

Dio

Flor.

Juv.

Mart.

Nep. Att.
Appian, Bella Civilia

Aristotle, Politica

Asconius, Commentary on Cicero, Pro Milone

Cicero, Epistulae ad Brutum

Cicero, Epistulae ad Atticum

Cicero, Pro Caelio

Cicero, Oratio in Catilinam

Cicero, Epistulae ad familiares

Cicero, De Haruspicum Responsis

Cicero, Pro Milone

Cicero, Pro Sestio

Cicero, De Provinciis Consularibus

Cicero, Orationes Philippicae

Cicero, Epistulae ad Quintum Fratrem

Cicero, In Verrem

Cassius Dio

Florus

Juvenal

Martial

Nepos, Atticus 
Ov. Am.

Plut. Vit. Ant.

Plut. Vit. Cic.

Plut. Comp. Demetr. Ant.

Plut. Demtr.

Prop.

Quint. Inst.

Sen. Const.

Sen. Con.

Sen. Ep.

Sen. Suas.

Suet. Aug.

Suet. Iul.

V. Max.

Vell. Pat.
Ovid, Amores

Plutarch, The Life of Antony

Plutarch, The Life of Cicero

Plutarch, Comparison of Demetrius and Antony

Plutarch, The Life of Demetrius

Propertius

Quintilian, Institutio Oratoria

Seneca, de Constantia

Seneca the Elder, Controversiae

Seneca, Epistulae

Seneca the Elder, Suasoriae

Suetonius, Divus Augustus

Suetonius, Divus Iulius

Valerius Maximus

Velleius Paterculus 


\section{CURRICULUM VITAE}

NAME: $\quad$ Erin Leigh Wotring

ADDRESS: 1495 West Elm Road

Radcliff KY, 40160

DOB: $\quad$ October 6, 1984

Elizabethtown, KY

EDUCATION: $\quad$ BA., History

University of Louisville,

May, 2011

AWARDS: Graduate Dean's Citation, 2017

U of L Faculty Favorite 2015-2017 